\title{
Power Mediators and Pure Mediators: \\ Exploring their Impact on Implementing Internal Peace \\ Agreements
}

\author{
Dissertation zur Erlangung des \\ Doktorgrades der Sozialwissenschaftlichen Fakultät \\ der Georg-August-Universität Göttingen
}

\author{
Vorgelegt von \\ Dogukan Cansin Karakus
}

Geboren in Istanbul

Göttingen, 2021 


\section{Thesis Committee}

First Supervisor: Prof. Dr. Anja Jetschke

Second Supervisor: Prof. Dr. Isak Svensson

Third Supervisor: $\quad$ Assistant Professor Jonathan Hall

Disputation: 13.11 .2020 


\begin{abstract}
Recent studies on international mediation have mainly focused on the impact of mediation on armed intra-state conflicts, emphasizing successfully completed ceasefires and peace agreements. Scholars have largely neglected the important part which mediation has played in implementing peace agreements. Accordingly, this dissertation aims at closing the research gap, analysing the impact of "pure" and "power" mediation on the successful implementation of peace agreements. To explain why some agreements have been successfully implemented, whereas others have experienced less progress, one should duly acknowledge the third-party mediators' performance involving various qualities such as leverage power, facilitation, communication, monitoring, dispute resolution, confidence-building, providing security and spoiler prevention, planning timetable and arranging financial support for the implementation process. This study demonstrates that multiple power mediators (the UK and the Republic of Ireland in Ulster) and multiple pure mediators (the UN and COPAZ in El Salvador) are mutually supportive in the successful implementation of peace agreements. They are by far more successful than a singly acting pure mediator (Organization of Islamic Cooperation in Mindanao) or a single power mediator (Syrian Arab Republic in Lebanon). My thesis conducts a case analysis and likewise a comparative case analysis of four comprehensive peace agreements, revealing the two highest and the two lowest degrees of implementation. It takes extensive account of the difficult conditions under which governments and rebels have implemented peace agreements supported by international mediators. It thus reinforces the theories and practice of international mediation, of implementing peace agreements and of sustainable peace. Failed implementation leads to humanitarian disasters such as in Angola, Rwanda, Liberia and Sierra Leone.
\end{abstract}

Keywords: intra-state conflict, mediation, pure mediator, power mediator, peace agreement, agreement implementation, case analysis, comparative analysis, sustainable peace 


\section{List of Contents}

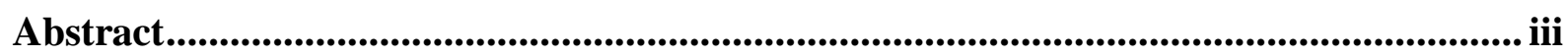

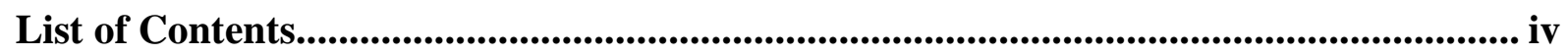

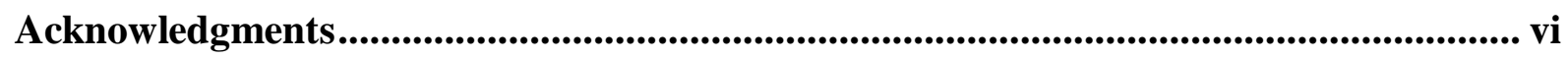

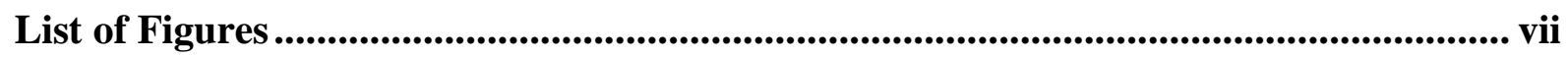

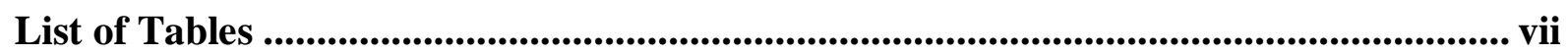

Acronyms ......................................................................................................................................... viii

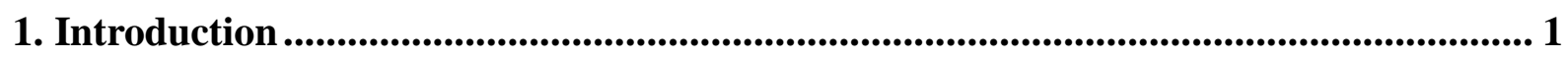

1.1 Rationale and Contributions .......................................................................... 4

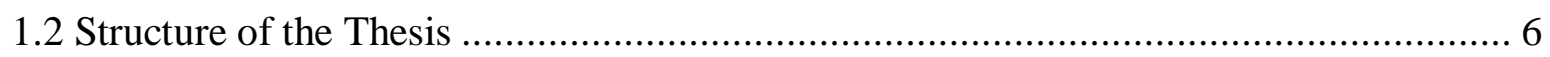

Chapter II: Literature Review and Research Gaps .............................................................. 8

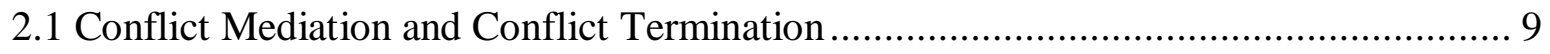

2.2 Mediation and Peace-Agreement Implementation ........................................... 12

Chapter III: Theoretical Framework ........................................................................................ 17

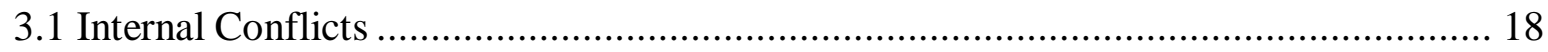

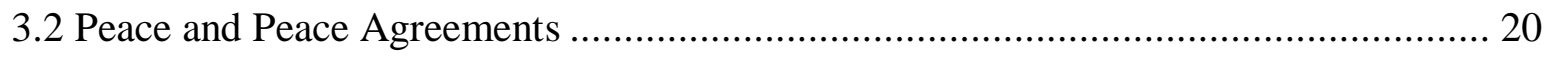

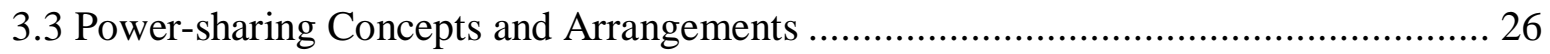

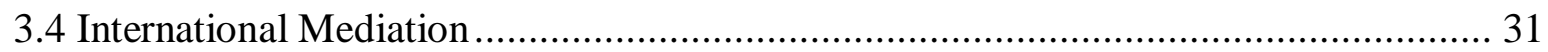

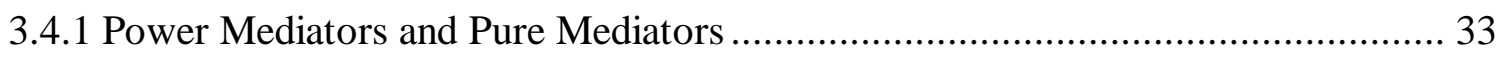

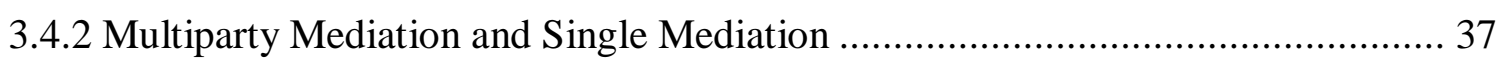

3.5 Mediator Tasks for Implementing Peace agreements .......................................... 40

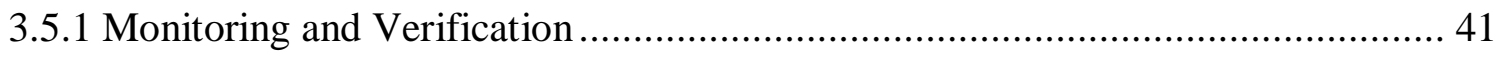

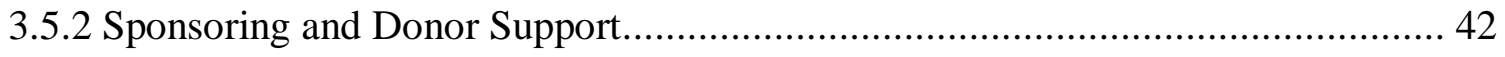

3.5.3 Resolution of Dispute and Commitment Problems ............................................. 43

3.5.4 Security Guarantees, Enforcement and Confidence-Building ........................... 45 


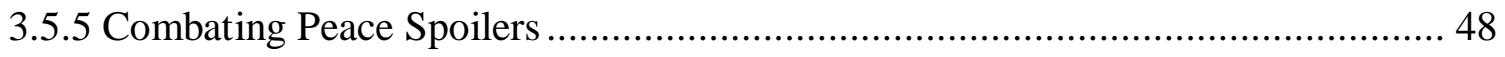

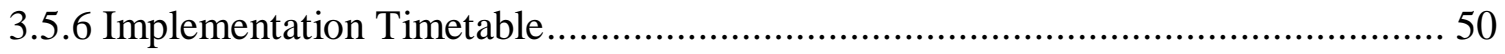

Chapter IV: Methodology and Research Design ....................................................... 52

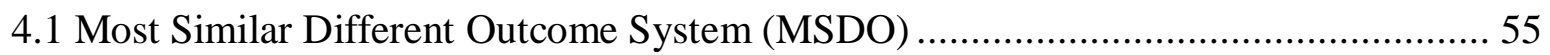

4.2 Case Selection Procedures ................................................................................. 56

4.2.1 Power Mediators and Pure Mediators .................................................................... 61

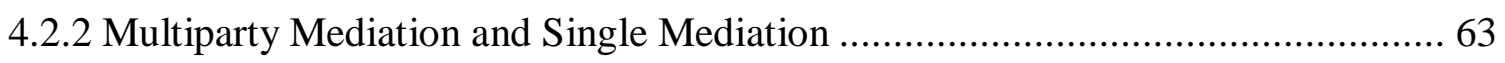

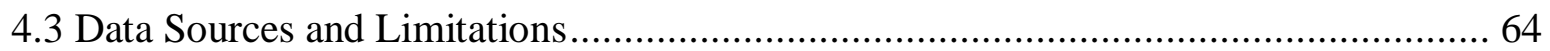

Chapter V: Case Study and Comparative Case Analysis ................................................ 66

5.1 Background of the Internal Armed Conflicts and Mediations ................................... 68

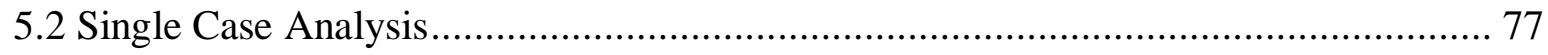

5.2.1 El-Salvador: Implementation of the Chapultepec Peace Agreement..................... 77

5.2.2 Lebanon: Implementation of the Ta' if Peace Agreement ................................. 99

5.2.3 Northern Ireland (UK): Implementation of the Good Friday Peace Agreement ...111

5.2.4 The Philippines: Implementation of the Mindanao Final Agreement ...................126

5.3 Comparative Case Analysis............................................................................... 141

5.3.1 Implementation of Ceasefire Arrangements ................................................ 141

5.3.2 Implementation of Institutional-governmental Power-sharing ..........................147

5.3.3 Implementation of Security Power-sharing ................................................158

5.3.4 Implementation of Human Rights and Reconciliation Arrangements ..................164

5.3.5 Implementation of Economic Power-Sharing ...............................................170

Chapter VI Conclusions: Academic and Practical Implications .....................................175

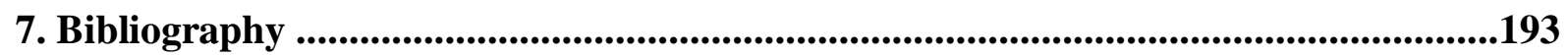

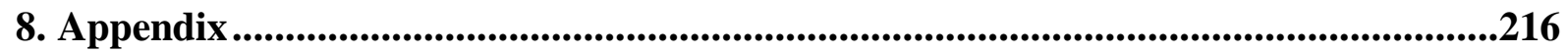

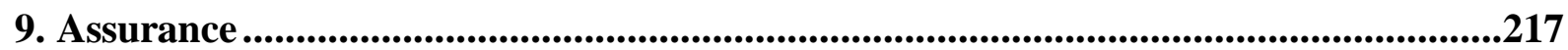




\section{Acknowledgments}

First and foremost, I would like to express my gratitude to Professor Anja Jetschke as the Chair of International Relations at Göttingen University. She was highly influential in the formulation of research problems and methods. Her constructive suggestions guided me to improve my perspective and raise the quality of my dissertation. Without her academic encouragement and interest, I would have been unable to launch my $\mathrm{PhD}$ thesis.

I would also like to thank my second supervisor, Prof. Dr. Isak Svenson, and my third supervisor, Assistant Professor Jonathan Hall, Department of Peace and Conflict Studies, University of Uppsala. They helped with everything, when I was a guest researcher at Uppsala University. I particularly appreciated the fact that they critically challenged some facets of my theoretical arguments, which taught me to equally consider different viewpoints and perspectives. I was happy to work closely together with them in a number of projects which were then published in peer-reviewed journals. I am especially grateful to Senior Professor Peter Wallensteen (Uppsala University), who initially supported my research project based on his suggestion that my research focus should be on problems in international mediation. I would also like to thank the staff of the Peace Research Institute Oslo for their great help. They largely contributed to the development of my dissertation, when I was a guest researcher there.

I would like to express my sincere gratitude to my mentor Wolfhard Goetzie, for his editorial feedback aimed at improving the syntax and correctness of my thesis. From the beginning of my master studies, he has always strongly supported me.

I would like to convey my gratitude to the Friedrich-Ebert Foundation for their generous support of my dissertation, conferences, and workshop travels. I would like to express my special gratitude to Kathrein Hölscher and Beate Eckstein, two staff members of the foundation, who assisted me in all kinds of scholarship questions throughout my entire research process.

Finally, I would like to thank my wife, Hatice Karakus, for all her wise advice, patience and love. 


\section{List of Figures}

Figure 1: Configuration of Most Similar, Different Outcome System Design (MSDO) ....... 56

Figure 2: Demonstration of single and multiple mediators in the selected cases 63

Figure 3: Triple-Team of Long-Term Mediators for Peace Agreement Implementation .....190

\section{List of Tables}

Table 1: Mediated and Non-Mediated Cases

Table 2: Implementation degree of peace agreements, names of short-term mediators before signing agreements.

Table 3: Pre-findings of mediator types between pure and power in selected cases before and after peace agreements. 62

Table 4: Police service of Northern Ireland 


\section{Acronyms}

$\begin{array}{ll}\text { ACT } & \text { Action for Conflict Transformation } \\ \text { AFP } & \text { Armed Forces of the Philippines } \\ \text { ARENA } & \text { Alianza Republicana Nacionalista } \\ \text { ARMM } & \text { Autonomous Region of Muslim Mindanao } \\ \text { ASEAN } & \text { Association of Southeast Asian Nations } \\ \text { ASG } & \text { Abu Sayyaf Group } \\ \text { AU } & \text { African Union } \\ \text { BBC } & \text { British Broadcasting Corporation } \\ \text { BIFM } & \text { Bangsamoro Islamic Freedom Movement } \\ \text { BIIC } & \text { British-Irish Intergovernmental Conference } \\ \text { CELAC } & \text { Community of Latin American and the Caribbean States } \\ \text { COPAZ } & \text { Comisión de Consolidación de la Paz } \\ \text { CRHRP } & \text { Country Report on Human Rights Practices } \\ \text { DDR } & \text { Disarmament, Demobilization and Reintegration } \\ \text { DRC } & \text { Democratic Republic of the Congo } \\ \text { ECHR } & \text { European Convention on Human Rights } \\ \text { ECRML } & \text { European Charter for Regional or Minority Languages } \\ \text { ECOMOG } & \text { Economic Community of West African States Monitoring Group } \\ \text { ECOWAS } & \text { Economic Community of West African States } \\ \text { ERP } & \text { People's Revolutionary Army } \\ \text { EU } & \text { European Union } \\ \text { FAES } & \text { Fuerza Armada de El Salvador } \\ \text { FMLN } & \text { Frente Farabundo Martí para la Liberación Nacional } \\ \text { FPL } & \text { Fuerzas Populares de Liberación } \\ \text { GFA } & \text { Good Friday Agreement } \\ \text { GRP } & \text { Government of the Republic Philippines } \\ \text { HIIK } & \text { Heidelberger Institute for International Conflict Research } \\ \text { ICTJ } & \text { International Center for Transitional Justice } \\ \text { ICTR } & \text { International Criminal Tribunal for Rwanda } \\ \text { ICTY } & \text { International Criminal Tribunal for the former Yugoslavia } \\ \text { IDP } & \text { Internally displaced people } \\ \text { IHREC } & \text { Irish Human Rights and Equality Commission } \\ \text { IICD } & \text { Independent International Commission on Decommissioning } \\ \text { IMF } & \text { International Monetary Fund } \\ \text { IMT } & \text { International Monitoring Team } \\ \text { IRA } & \text { Irish Republican Army } \\ \text { LVF } & \text { Loyalist Volunteer Force } \\ \text { MFA } & \text { Mindanao Final Agreement } \\ \text { MILF } & \text { Moro Islamic Liberation Front } \\ \text { MINUSAL } & \text { United Nations Mission in El Salvador } \\ \text { MNLF } & \text { Moro National Liberation Front } \\ \text { MSDO } & \text { Most Similar Different Outcome } \\ \text { NATO } & \text { North Atlantic Treaty Organization } \\ \text { NGO } & \text { Non-governmental Organizations } \\ & \end{array}$




$\begin{array}{ll}\text { ODECA } & \text { Organización de Estados Centroamericanos } \\
\text { OIC } & \text { Organisation of Islamic Cooperation } \\
\text { OMSAR } & \text { Office of the Minister of State for Administrative Reform } \\
\text { ONUSAL } & \text { United Nations Observer Group in El Salvador } \\
\text { ONUV } & \text { United Nations Office of Verification in El Salvador } \\
\text { ORDEN } & \text { Organización Democrática Nacionalista } \\
\text { PAM } & \text { Peace Accords Matrix } \\
\text { PIRA } & \text { Provisional Irish Republican Army } \\
\text { PNC } & \text { Policia Nacional Civil } \\
\text { PSNI } & \text { Policing in Northern Ireland } \\
\text { PTSD } & \text { Post Traumatic Stress Disorder } \\
\text { RUC } & \text { Royal Ulster Constabulary } \\
\text { SDLP } & \text { Social Democratic and Labour Party } \\
\text { SPCPD } & \text { Southern Philippines Council for Peace and Development } \\
\text { SZOPAD } & \text { Special Zone of Peace and Development } \\
\text { TJPA } & \text { Transitional Justice Peace Agreements } \\
\text { TRC } & \text { Truth and Reconciliation Commission } \\
\text { UCDP } & \text { Uppsala Conflict Data Program } \\
\text { UDA } & \text { Ulster Defense Association } \\
\text { UN } & \text { United Nations } \\
\text { UNDP } & \text { United Nations Development Program } \\
\text { UNIFIL } & \text { United Nations Interim Force in Lebanon } \\
\text { UNITA } & \text { National Union for the Total Independence of Angola } \\
\text { UNMDP } & \text { United Nations Multinational Donor Program } \\
\text { UNMIL } & \text { United Nations Mission in Liberia } \\
\text { UNPROFOR } & \text { United Nations Protection Force } \\
\text { UK } & \text { United Kingdom } \\
\text { USA } & \text { United States of America } \\
\text { USSR } & \text { Union of Soviet Socialist Republics } \\
\text { UUP } & \text { Ulster Unionist Party }\end{array}$




\section{Introduction}

Civil wars cause lots of humanitarian crises. Tens of thousands of people lose their lives or suffer severe physical injury. Civil-war victims suffer famine and malnutrition, as their country's economy and infrastructure has been utterly devastated. The deterioration of health services leads to the emergence of epidemic diseases. Many of those who witnessed civil war violence have been psychologically traumatized. Victims are internally displaced and leave their homes to seek political asylum in foreign countries. Many of them lose their lives on migration routes. Countries hosting large numbers of refugees are now facing clashes between refugees and their local population. Refugees are confronted with economic crises, racism and increasingly powerful right-wing political parties. The power vacuum in civil war-torn countries has given rise to terrorist organizations violently oppressing the civilian population. New power struggles and proxy wars occur between regional or international powers. Problems caused by civil wars pose a major challenge for the UN and regional organizations in terms of conflict resolution and humanitarian aid. As to the Uppsala Conflict Data Program, the number of civil wars between 1946 and 2017 largely increased (UCDP 2018) and has still been on the increase since then (e.g., Syria, Yemen, Libya, Afghanistan, Iraq).

Resolving civil wars is a challenging research task for scholars and policymakers aiming at peacebuilding. It requires a specific theoretical background, practical skills and a profound understanding of different cultures and history. Scholars engaged in peace and conflict studies have tried to identify possible causes of civil wars, maintaining that civil wars are generally due to governmental, territorial or economic power-sharing issues. Reaching a peaceful consensus in terms of governmental and territorial power-sharing between conflicting parties poses a great challenge. Trying to overcome such challenges, numerous political scientists in international mediation have developed various approaches to successfully mediate internal conflicts. However, mediation success is a relative concept. The question is what constitutes success (components of success) and how can it be adequately measured (Kleibor 1996; Bercovitch 2005, 289). It has been generally acknowledged that whenever a conflict termination has been achieved, the mediation has been assessed as successful. The Peace Accord Matrix of the Kroc Institute recorded 34 comprehensive peace agreements, dating from 1989 to 2012. Twenty-six 
of them were achieved employing external mediation (Joshi et al. 2015; Högbladh 2011; DeRouen et al. 2011).

As to resolving civil wars, the UN has repeatedly engaged itself in various peace initiatives at the international level because of its commitment for peacebuilding (Wallensteen 2015, 14). The same applies to the peacebuilding activities of regional organizations. After and during the Cold War, regional organizations (e.g., the EU, the African Union, the ECOWAS, the OIC, ASEAN), NGOs, and single states (Scandinavian countries, the US and Switzerland) also undertook peace initiatives in that respect. Civil wars are resolved via diplomatic channels (e.g., mediation, negotiations), economic or political sanctions, military intervention or one-sided victory. Some internal conflicts are "frozen” (e.g., Cyprus, Kosovo, Nagorno-Karabakh), which means, although peace is being kept, the conflict has not been completely resolved (Perry 2009, 40). Some civil wars seemed to end on a hopeful note, but a substantial peace agreement eventually failed. According to DeRouen et al. (2010, 333), studies have demonstrated that execution of civil war peace settlements is complex and likely to fail. Walter $(2002,5)$ likewise maintains that peace agreements in their implementation period are on the verge of failing, as former conflicting parties "have the greatest difficulty implementing the resulting terms." Implementation requires strict time-planning and urges rival parties to constant commitment. Third parties acting as mediators are empowered to provide security and perform monitoring implementation activities. If their implementation capacity were to fail, renewed internal conflicts would emerge and mistrust between the opposing parties would be spread. Another problem could be that conflicting parties were to vehemently oppose a third party's involvement in the implementation process. The third party's presence would then be erroneously understood as interference in internal affairs.

Recent studies have been focusing on the impact of mediation on intrastate armed conflicts, highlighting ceasefire and peace accords. However, they have given scant attention to peace agreements after the termination of internal conflicts, after a long time. I, therefore, wish to find out what happened ten years later, after the agreement had entered into force and to what extent the rules and obligations set out in the peace agreement were still obeyed by the respective parties. Those rules were implemented by signatories under new legal guarantees. There have been very few single cases analyses into the success of power-sharing peace agreements and 
post-agreement implementation periods. This field of research has not been thoroughly examined yet (DeRouen and Chowdhury 2013, 8-9). Accordingly, this dissertation is closing a gap in the field of international mediation and implementation research by exploring the following research question: Under what conditions can external (pure and power) mediators enhance the implementation of mediated intrastate peace agreements? In this thesis, single case analysis and a comparative analysis of four post-agreement countries have been conducted. Four countries out of 26 mediated peace agreements dating from 1989 to 2012 were systematically selected (Joshi et al. 2015). Pure mediators, such as international organizations (the UN, the Comisión de Consolidación de la Paz (COPAZ), the Organization of Islamic Cooperation (OIC) and power mediators (the UK, the Irish Republic, Syria) were all involved in the implementation processes over ten years.

I argue that multiple "power" or "pure" type third-party mediation" is crucial to enhance a successful implementation process. By contrast, single pure or single power mediators are less likely to enhance successful implementation, as shown in the comparative and single-case analyses of El Salvador, Northern Ireland (UK), Lebanon and Mindanao (the Philippines). As peace agreements include challenging provisions in terms of governmental and territorial power-sharing, disarmament and ceasefire, it requires multiple third-party monitoring, leverage, assistance, security, specific knowledge, coordination, facilitation, guarantee and financial support. Peace spoilers are likely to violate peace processes since they do not comply with any peace agreements. Third-party mediators providing security guarantee are necessary to prevent the violation of agreements and any kind of conflict recurrence. When the provision of disarming a rebel group has been implemented, an experienced third-party mediator should coordinate the specific decommissioning processes. Multiple mediators can likewise ensure secure elections and carefully monitor them. In case an implementation process should prove unsuccessful, third-party mediators could still persuade parties to keep the implementation process running by arranging financial and technical assistance. As long as multiple third

\footnotetext{
1 "Power mediators are defined as mediation efforts by great powers, colonial powers, and neighbouring states, whereas mediators who are representatives of international, regional, or non-governmental organizations, individuals, and small and distant states, are classified as pure mediators" (Svensson, 2007, 230). "Power - the ability to move a party in an intended direction - is often referred to in mediation as "leverage". The "powerless" or "pure" mediator, however, is to persuade parties lacking leverage to communicate more easily with each other (Zartman and Touval 1996, 436-439).
} 
parties work together and mutually share specific responsibilities, successful peace implementation will be more likely. A singly acting third-party mediator is less likely to be successful (e.g., Lebanon and Mindanao, the Philippines). The lack of political will, financial support, experience or personal skill hampers implementation processes. Sometimes a single mediator takes sides with one of the rival parties out of political, economic or military interest in the country concerned. In that case, specific provisions can only be partially implemented by a single mediator.

We remember the mediation work of certain implementation facilitators such as Martti Ahtisaari, former President of Finland, who personally committed himself to the implementation process of the Aceh Peace Agreement in Indonesia. Carl Bildt, former Swedish Prime Minister, served as a mediator in the implementation process of the Dayton Peace Agreement (1996-97). He was largely responsible for building up a democratic framework in Bosnia and Herzegovina. Nelson Mandela, former president of South Africa, arranged financial support for Burundi in the implementation process of the Arusha Peace and Reconciliation Agreement (2000). Successful mediators should share their valuable experience, assisting other mediators in future implementation processes, as they have become fully knowledgeable of core incompatibilities and have learnt to find proper solutions.

\subsection{Rationale and Contributions}

The dissertation takes extensive account of the difficult conditions under which governments and rebels have implemented peace agreements supported by third parties. Why is the impact of third-party mediation on implementation processes of intrastate peace agreements important? One main rationale justifies the necessity for this study. Dissatisfaction among post-agreement parties with missing implementation and power-sharing content are likely to engender a breach of agreements and nothing is done by state officials and third parties to provide lasting peace. DeRouen et al. $(2010,334)$ argue that international third parties are likely to contribute to conflict termination; however, they are not involved in implementation processes. In that sense, state capacity is required for successful implementation. Third parties should remain present 
until the full implementation of a peace agreement has been achieved. They should act on behalf of a weak state capacity and provide assistance and security in post-conflict periods. To implement the Dayton Peace Agreement "more than 20 billion dollars" were needed; "35 billion dollars" were spent on the Arusha Peace Agreement (Stedman 2002, 661). The Centre for Humanitarian Dialogue (2007, 13) maintains that a general lack of support for peace agreements might lead to failure. It states that " $43 \%$ of wars in the 1990s restarted within five years of an initial negotiated" arrangement. Failed peace agreements in Angola (1993) and Rwanda (1994) resulted in large numbers of casualties (Stedman 2001, 20). As any violation of peace agreements should be strictly avoided, external third parties should carefully monitor the implementation process. They should forecast spoiling problems soon, provide security, replace missing state capacity, provide confidence-building between hostile parties and create dialogue networks at local levels. In that regard, the role of third-party mediation remains underrated in the research field of international mediation. This dissertation aims to closely examine the long-term role of third-party mediation.

Power and pure mediators are from different international or regional organizations. They belong to different third countries and NGOs. Their impact on reaching a successful implementation is therefore highly diversified due to their different skills, capacity and support services. The implementation of single provisions (e.g., ceasefire arrangements, institutional reforms, security reforms or financial supports) presents a tremendous challenge to mediators, especially as certain provisions which are related to the outbreak of the conflict are more difficult to implement. A failure to implement those provisions might trigger an eruption of violence. Joshi and Darby $(2013,270)$ argue that conflict recurrence would increase in case of failed implementation of peace arrangements.

The single case analyses and comparative case analyses in this dissertation contribute the importance of different third parties in implementation processes: cooperation of the UN with COPAZ in El Salvador, the Organization of Islamic Cooperation (OIC) in Mindanao (the Philippines), the United Kingdom together with the Republic of Ireland in Ulster and Syria as the only third party in Lebanon. They provide new insights into the theory and practice of international mediation in terms of territorial, economic, security and governmental powersharing agreements. As to the above-mentioned rational, this thesis largely contributes to the 
theory of international mediation and the implementation of power-sharing peace agreements. It emphasizes post-conflict peacebuilding, the prevention of conflict recurrence and sustainable peace. It bridges the gap between present theory and the practice of international mediation.

\subsection{Structure of the Thesis}

The dissertation comprises various sections: introduction to the subject matter, rationales and contributions. The individual chapters address the following topics: Chapter II: Literature Review and Research Gaps and layout. Chapter III: Theoretical Framework, Chapter IV: Methodology and Research Design, Chapter V: Single Case and Comparative Case Analyses of El Salvador, Lebanon, Northern Ireland (UK) and the Philippines, Chapter VI: Main Conclusion - Academic and Practical Implications.

Firstly, Chapter III summarizes essential elements of the theoretical framework of discussions found in literature about intra-state peace agreements, territorial and governmental powersharing arrangements, transitional justice in post-conflict societies, international mediation, power mediation versus pure mediators, strategic coordination between multiple mediators versus single mediator which is to increase or diminish implementation success. Finally, the special tasks of external mediators in terms of peace agreement implementation processes are introduced. They are crucial functions for implementation: monitoring and verification, sponsoring and donor support, dispute resolution services, confidence-building mechanisms, third-party security guarantees, combating peace spoilers, commitment problems and external enforcement mechanisms, as well as implementation timetables. Chapter IV: Methodology and research design, single case and comparative case analyses (MSDO), case selection procedures, identification of dependent and independent variables, data sources and limitations, detailed elements of the thesis project.

Chapter V closely analyses the four selected cases individually and compares them with one another systematically, depending on the specified constant categories of implementation. They have clustered in five categories: 1) Implementation of ceasefire arrangement 2) 
Implementation of institutional-governmental power-sharing 3) Implementation of security power-sharing 4) Implementation of human rights and reconciliation arrangements 5) Implementation of economic power-sharing. In the framework of that procedure, the basic research question is strictly observed. This chapter deals with the respective backgrounds of internal armed conflicts, types of mediation, the enormous efforts made by mediators until peace agreements were signed, the presentation of various subject matters on power-sharing arrangements. Furthermore, arrangements are being examined individually, taking into account the given post-conflict conditions, the spheres of action and achieved agreements, ascribing importance to the assessment of long-term mediation over ten years. Finally, chapter VI contains the most significant conclusion to be drawn from this thesis. It presents the academic and practical implications of the findings. 
Chapter II:

Literature Review and Research Gaps 
Intra-state conflict mediation is playing an increasingly important part of peacebuilding and conflict resolution. In recent years, literature dealing with international mediation has emphasized short-term mediation efforts, effects and success in international armed conflicts, aiming at achieving ceasefires and peace agreements. However, less attention has been paid to long-term mediation effects in post-agreement implementation processes. Peace agreements are sometimes doomed to fail in implementation processes. This literature review predominantly presents research on conflict mediation, the conceptualization of successful mediation and peace-agreement implementation. Research gaps based on the present literature are identified. It will facilitate to concretize the research question of the thesis which has not been answered yet.

\subsection{Conflict Mediation and Conflict Termination}

Countries having suffered from civil wars are more likely to face new civil wars according to statistics from the World Development Report (Call 2012, 2). In that regard, successful international mediation plays an important role to resolve conflicts and prevent their recurrence. Literature dealing with international mediation emphasizes the active role of mediation in connection with the termination of internal conflicts. Research questions are asked; "When" should third-party mediation occur in a military conflict? "How" should it occur? Which "strategy of mediation" would be most successful? "What" should be done in the postagreement process to achieve lasting peace? (Duursma 2014, 82-83). However, international mediation success is a relative, temporal and complex concept. Conventionally, short-term assessments have been used to define success in mediation evaluation (Bercovitch and Simpson 2010, 69). Various approaches - mediator's identity and characteristics, mediation styles, conflict circumstances and intensity, the number of mediators - in terms of empirical measurement and assessment relating to international conflict mediation outcomes have been widely discussed and analysed by a great number of scholars (Frei 1975, 1976; Kleiboer 1996; Bercovitch 1991, 1996, 2011; Carnevale and Arad 1996; Walter 2002; Bercovitch and DeRouen 2004, 2005; Svensson 2006, 2007, 2009; Doyle and Sambanis 2006; Savun 2008; Greig and Regan 2008; Clayton 2013; Beardsley 2011; Bercovitch 2011; Sandu 2013; 
Wallensteen and Svensson 2014). Case analysis was conducted by Sisk (2009) to assess the role of international mediators in internal conflicts in South Africa, Liberia, Burundi, Kashmir, and Sri Lanka.

One of the historical contributions in the mediation field is provided by Frei (1975). He statistically evaluates causal mechanism and conditions that promote mediation success through a systematic comparison of historical cases, facts and mediation efforts in international conflicts (1960-1974). He argues that mediation success depends on conflict parties and structural preconditions. Mediation proves successful, if the conflicting parties are widely acknowledged as warring factions, have less conflict inside the parties, financially dependent on external actors, mediation is supported by an international organization, by superpowers and mediators that have not been involved in the conflict with either party. The success can be weakened by the conflict incompatibilities in terms of decolonization, power-sharing and security issues and the high intensity of ongoing conflict (Frei 1975, 484-486). The acceptance of external thirdparty mediation in certain internal conflicts has been interpreted as success. The variation of success is further conceptualized in terms of mediation occurrence and non-occurrence between conflicting parties by Frei $(1976,69)$. In the following theoretical development, the success of conflict mediation can be determined, when a ceasefire or peace agreement has been reached in a short-term process, a fact which has been commonly acknowledged (Savun 2008, 25). Similarly, success can be determined when a peace agreement has been signed through mediation (Bercovitch et al. 2009, 205-206; Pospieszna and Schneider 2011, 2). Once all parties are pleased with the procedure or the result, mediation is deemed successful. This subjective criterion is related to the perception of parties, mediators, and to some extent, to external actors (Bercovitch 2011, 85). The result Bercovitch has achieved is derived from two case studies (The Camp David and Oslo mediations) and an intensive quantitative study concerning the time of 1945 and 1995 (295 international conflicts and 1,666 mediation cases). The benchmark of satisfaction comes from Susskind and Cruikshank (1987) ${ }^{2}$. Here one can see that public satisfaction has been widely overlooked. It should equally play an important part in postagreement periods, otherwise, a conflict recurrence can occur in post-conflict societies.

\footnotetext{
2 See, Susskind, L. E., and Cruikshank, J. (1987). Breaking the Impasse: Consensual Approaches to Resolving Public Disputes. New Yorkl Basic Books. Inc., Publishers.
} 
Sandu (2013) qualitatively focuses on indicators and qualities impacting successful mediation processes and mediator skills. An assumption is developed by his fellow practitioners of the Transylvanian Institute for Mediation: "Successful mediation" would be one where the conflict parties should not appeal to someone else with identical issue in the long-term (ibid. 31), Sandu emphasizes four values of success in mediation processes, pointing out the positive effect of mediation: fairness, efficiency, satisfaction and effectiveness. Other factors are presented that might influence success: Selection of a fair mediator, proper preparation for mediation, a clear resolution mandate and personal qualities such as listening skills, confidentiality, neutrality, trust, optimism and modesty (ibid. 35-39). Kleiboer (1999, 13) insists that mediation eventually ends in a sustainable settlement agreed and endorsed by all parties to the dispute. In contrast, Nathan $(1999,3)$ defines success as the end of hostilities between former enemies and the beginning of democratic rule which is to support lasting peace. Svensson (2014), however, suggests having a peace institution regulating core incompatibilities in conflicts within the framework of "power, security, and justice".

Kleiboer (1996) critically deals with the state of the arts in terms of successful international mediation in the light of contextual factors i.e., "characteristics of the dispute, parties and their interrelationship, characteristics of the mediator and the international context". The most important point of criticism is the "conceptual" vagueness in terms of "dependent variables, how to measure success? and the independent variables i.e., when is conflict ripe for resolution? when can a mediator be considered powerful?" Explaining the success of mediation is not explicitly determined where it ends up (Kleiboer 1996, 376). Moreover, qualitative assessments can be empirically backed up. Bercovitch and Simpson contend that if we have a long-term interpretation of success, we should acknowledge it can take 10 to 15 years to assess if a peace deal will endure and would therefore be effective $(2010,73)$. A peace agreement can last even more than 10 years without a full implementation (e.g., General peace agreement between the Government of the Republic of Senegal and the Movement of Democratic Forces in the Casamance, 2004, Bodo Accord between the Government of India and the Government of Assam, 1993). Those peace agreements do not ensure the optimum of quality peace. The longterm perspective of success is closely related to the implementation success of peace agreements. This will be further discussed below. Quantitative analysis might prove to be 
problematic, as it might ignore some of the qualitative aspects of the components of success in post-agreement periods.

Another challenge regarding success conceptualization is the question of who defines the generally valid criteria of success. Should it be the third-party mediators or the rival parties? Is public satisfaction the ultimate step in the perception of mediation success? It is important to understand that all three questions belong together and depend on one another. As the mediator strictly aims to reach a peace agreement, the rival parties rigorously strive for an effective ceasefire agreement and the public eagerly wishes a beneficial agreement on specific provisions such as security or social justice, the high expectations and hopes of the mediator, rival parties and the civilian population seem to greatly differ from each other, but viewed in its entirety, they complement each other in terms of success achievement. Only if different expectations are fully respected in a peace-building process, mediation can prove itself successful.

\subsection{Mediation and Peace-Agreement Implementation}

The book, Ending Civil Wars - The Implementation of Peace Agreements was published in collaboration between the International Peace Academy and the Center for International Security and Cooperation (Edited by Stephen John Stedman, Donald Rothchild, Elizabeth M. Cousens 2002). Researchers, practitioners and diplomats contribute to implementation strategies and tasks based on case studies on how to ensure implementing peace agreements. Stedman $(2002,2)$ considers a mediation process as successful when a peace agreement has been signed and fully implemented and the help of a third party is no longer needed. This means sustainable peace has been achieved between former warring parties. The country's selfgovernance has been re-established, which underlines the utmost importance of sustained peace and prevents the recurrence of civil wars. The implementation of peace agreements is to be considered as a long-term temporal process that always requires improvement in the long run. Elizabeth Cousens, director of Strategy at the Centre for Humanitarian Dialogue, summarizes long-term mediation and implementation processes in unequivocal terms: 'it ain't over 'til it's over" (HD Center for Humanitarian Dialogue 2007). Accordingly, due to third-party mediation, 
success via implementation will provide a novel academic impulse to political scientists involved in international mediation. This research is based on concrete circumstances such as intra-state conflicts. Therefore mediation, peace agreements and implementation processes are successive in this context. They are related to each other and should be jointly considered.

In quantitative and qualitative literature dealing with peace duration and the implementation of peace agreements, consideration has been given to explaining variables. Bercovitch and Simpson (2010) have investigated three cases, Angola, Sri Lanka and Sierra Leone, emphasizing three main factors generally accepted in policy-related literature on lasting peace: Dealing with peace spoilers, international security guarantee, and military power-sharing. They explain that these factors should be considered carefully to facilitate lasting peace in postagreement periods. According to DeRouen and Chowdhury (2013, 1), who use logit models (1975-2011), the associated factors between implementation and peace agreements are "credible commitment problems". They are due to the government's incapability of implementing peace agreements and handling disputants starting a new wave of violence. Stedman points out that a peace agreement might be violated by a spoiler who has been opposing the agreement right from the outset or during the implementation process (i.e., excluding conflicting parties from the same location/region). Spoilers occurred in Angola (1992) and Rwanda, in 1994 (National Research Council 2000, 178). In 2008, the Center for Humanitarian Dialogue (2008, 66-67) summarized the following important factors for implementation in the Oslo Forum Networks for Mediators: Monitoring and dispute-resolution mechanisms, peace spoiler prevention mechanism and providing confidence-building support between local and regional actors.

Joshi and Darby (2013) introduced the Peace Accords Matrix which enables researchers to compare 35 peace agreements between 1989 and 2007. They emphasize socio-economic development and security-related provisions such as the military, police, DDR programs (disarmament, demobilization and reintegration of former fighters). These provisions and socio-economic development particularly support successful post-peacebuilding (Joshi and Darby 2013, 255, 268). Hoddie and Hartzell (2003) argue that implemented military powersharing provisions such as the reintegration of former fighters are beneficial to sustainable peace. Pospieszna and Schneider (2011) associate power-sharing provisions and security 
guarantees provided by third parties. According to them, both are successful to implement peace but do not guarantee durable peace. The result is derived from a probit regression models. Arnault (2006) emphasizes the interaction of UN peacekeeping forces and implementation, particular focus is set on the role of the UN in El Salvador and Guatemala.

According to Walter (2002), combatants eagerly require credible third-party enforcement comprising verification mechanisms and security guarantees, which ensures success in powersharing implementation. She empirically analyses numerous civil wars between 1940 and 1992 . Hartzell and Hoddie $(2003,327)$ point out that the involvement of a third-party executioner minimizes the likelihood of settlement collapse by 83 per cent. Numbers of external third-party arrangements occurring between 1989-2007 have been provided by Joshi and Darby (2013, 266): The most popular provision for an international settlement is involvement of the United Nations, the diplomatic or domestic monitoring mechanism and the UN peacekeeping arrangement. A statistical study undertaken by Fortna (2004) goes in the same direction to focus on the effect of peacekeeping: Peacekeeping following civil conflict does make a substantial contribution to peace preservation. Jarstad and Nilsson (2008) present a new dataset in terms of the implementation of power-sharing pacts after the time of the Cold War. According to Jarstad and Nilsson $(2008,219)$, the presence of a UN or non-UN organisation has no bearing on the likelihood of peace breaking down. An important sign of peace anticipation is identified, in case, if the military and territorial power-sharing provisions are implemented. In contrast, the impact of political power-sharing is insignificant for lasting peace. In this research, international mediators are not included to focus on implementation.

One of the less investigated factors in that context is the level of state capacity to implement peace agreements. Civil war-torn countries with fragile economies are not able to financially secure a peace process for lack of funds. "More than 20 billion dollars" were needed to implement the Dayton Peace Accord, "35 billion dollars" were needed in the Arusha-PeaceAgreement (Stedman 2002, 661). This variable has been thoroughly examined by DeRouen et al. (2010) utilizing 14 peace agreements which show that state capacity is urgently needed to maintain lasting peace. Sobek (2010) has also provided a close analysis of different variables about state capacity and the onset and outcome of civil wars. He argues that the risk of civil 
war is lower in countries with strong economies. If civil war should break out there, social conditions in those countries would generally facilitate peace negotiations.

Stedman $(2002,148)$ emphasizes five key elements leading to successful implementation processes: "the peace accord itself, the implementation environment, the implementers, the warring parties, and verification". 26 of 31 intra-state comprehensive peace agreements between 1989 and 2012 were achieved utilizing mediation efforts by accordance with the Civil War Mediation Dataset (DeRouen et al. 2011), the Peace Accord Matrix (Joshi et al. 2015) and "the UCDP Peace Agreement Dataset" (Högbladh 2011). Signing a peace agreement is seen as a successful, short-term mediation result by some scholars. However, the impact of mediators (type and number) on effective implementation processes in specific provisions has been neglected in previous research. The following illustration summaries the causal mechanisms which explain sustainable post-peace building and implementation of the peace agreement in the post-conflict stage:

\begin{tabular}{|c|c|c|c|}
\hline $\begin{array}{l}\text { Previous } \\
\text { research by }\end{array}$ & Causal mechanisms and factors & $\begin{array}{l}\text { Effect on } \\
\text { sustainable } \\
\text { post-peace } \\
\text { building }\end{array}$ & $\begin{array}{l}\text { Effect on } \\
\text { implementation } \\
\text { of the peace } \\
\text { agreement }\end{array}$ \\
\hline $\begin{array}{l}\text { Bercovitch } \\
\text { and Simpson } \\
(2010)\end{array}$ & $\begin{array}{l}\text { - dealing with peace spoilers } \\
\text { - } \text { international security guarantee } \\
\text { - military power-sharing } \\
\end{array}$ & $\checkmark$ & \\
\hline $\begin{array}{l}\text { DeRouen and } \\
\text { Chowdhury } \\
(2013)\end{array}$ & $\begin{array}{l}\text { - } \text { credible commitment problems } \\
\text { - government's incapability }\end{array}$ & $\sqrt{ }$ & \\
\hline $\begin{array}{l}\text { Stedman } \\
(2002)\end{array}$ & $\begin{array}{l}\text { - } \text { peace spoiler prevention } \\
\text { - } \text { state capacity } \\
\text { - financial support } \\
\text { - } \text { peace accord itself } \\
\text { - implementation environment } \\
\text { - implementers } \\
\text { - } \text { warring parties } \\
\text { - } \text { verification }\end{array}$ & & $\checkmark$ \\
\hline $\begin{array}{l}\text { Center for } \\
\text { Humanitarian } \\
\text { Dialogue } \\
(2008)\end{array}$ & $\begin{array}{l}\text { - monitoring and dispute-resolution } \\
\text { mechanisms } \\
\text { - peace spoiler prevention mechanism } \\
\text { - providing confidence-building }\end{array}$ & & $\sqrt{ }$ \\
\hline $\begin{array}{l}\text { Joshi and } \\
\text { Darby (2013) }\end{array}$ & $\begin{array}{l}\text { - } \text { socio-economic development } \\
\text { - security-related provisions such as } \\
\text { the military, police, DDR programs }\end{array}$ & $\sqrt{ }$ & \\
\hline
\end{tabular}




\begin{tabular}{|c|c|c|c|}
\hline $\begin{array}{l}\text { Hoddie and } \\
\text { Hartzell } \\
(2003)\end{array}$ & $\begin{array}{l}\text { - military power-sharing provisions } \\
\text { - third party enforcement }\end{array}$ & $\checkmark$ & $\checkmark$ \\
\hline $\begin{array}{l}\text { Pospieszna } \\
\text { and Schneider } \\
(2011)\end{array}$ & $\begin{array}{l}\text { - } \begin{array}{l}\text { power-sharing provisions and } \\
\text { arrangements } \\
\text { - security guarantees provided by third } \\
\text { parties }\end{array} \\
\end{array}$ & & $\sqrt{ }$ \\
\hline $\begin{array}{l}\text { Arnault } \\
\text { (2006) }\end{array}$ & UN peacekeeping forces & & $\sqrt{ }$ \\
\hline Walter (2002) & $\begin{array}{l}\text { - credible third-party enforcement } \\
\text { comprising verification mechanisms } \\
\text { and security guarantees }\end{array}$ & & $\sqrt{ }$ \\
\hline $\begin{array}{l}\text { Joshi and } \\
\text { Darby (2013) }\end{array}$ & - UN peacekeeping verification & & $\sqrt{ }$ \\
\hline $\begin{array}{l}\text { Jarstad and } \\
\text { Nilsson } \\
(2008) \\
\end{array}$ & $\begin{array}{l}\text { - Implementation performance of the } \\
\text { military and territorial power-sharing } \\
\text { provisions }\end{array}$ & $\sqrt{ }$ & \\
\hline $\begin{array}{l}\text { DeRouen et } \\
\text { al. }(2010)\end{array}$ & - state capacity & $\sqrt{ }$ & \\
\hline Sobek (2010) & $\begin{array}{l}\text { - state capacity and strong economy of } \\
\text { a post-conflict country }\end{array}$ & $\sqrt{ }$ & \\
\hline
\end{tabular}

In general, we can affirm that independent variables and causal mechanisms in the abovementioned table have been taken into due consideration by scholars to associate lasting peace and the implementation of peace agreements in quantitative analysis. However, the implementation of peace agreements has not been thoroughly investigated on the subject of long-term mediators over a long time yet, as these peace agreements comprise numerous single power-sharing provisions. Considering that there is no comprehensive study in that field, there is ample scope for an in-depth comparative case study. That will enable us to qualitatively assess the impact of third-party mediation (single or multiple mediation, pure or power mediation) on various provisions of peace agreements in implementation processes. This thesis aims at filling a research gap in international mediation, focusing on the time after the termination of internal conflicts and the implementation of a peace agreement. Therefore, this dissertation is exploring the following research question: Under what conditions can external (pure and power) mediators enhance the implementation of mediated intrastate peace agreements? 
Chapter III:

Theoretical Framework 
Any observational or semi theory of social or psychological processes, at diverse aspects, that can be generalized to the perception of phenomena is known as a theoretical framework (Anfara and Mertz 2015). To understand the phenomena of mediator impact on peace agreement implementation process, the following steps are organized:

Firstly, this chapter summarizes essential elements of the theoretical framework of discussions found in literature about mediation, peace-conceptualization, peacebuilding, a peace agreement, intra-state conflict and incompatibilities. Secondly, international mediation is dealt with in terms of international, regional and domestic actors, numbers, strategies, characteristics and success rate. The concepts of power versus pure mediation and strategic coordination of conflict mediation (single versus multiple mediators) are introduced. Long-term pure and power third-party mediation encompassing a wide range of tasks, procedures and factors during the implementation process of power-sharing peace agreements is discussed (e.g., monitoring and verification, sponsoring and donor support, resolution of dispute and commitment problems, security guarantee, enforcement and confidence-building, peace spoiler-prevention and implementation of timetable). The quality of peace agreements, mediator effect on transitional justice mechanisms is shown. Subsequently, internal peace agreements are summarized in which transitional justice regarding victim provisions has been incorporated. Thirdly, the main focus is set on the implementation issue of peace agreements, as it is an essential part of processing the research question. Finally, gaps and shortcomings that exist in the complex argumentation based on the present theory of international mediation are addressed.

\subsection{Internal Conflicts}

According to the definition of the Uppsala Conflict Data Program (UCDP), an intra-state conflict takes place "between a government and a non-governmental party, with no interference from other countries". It is defined in similar terms by the "Heidelberger Institute for International Conflict Research" (HIIK): "intra-state conflicts are conducted between non-state actors and national governments. Sub-state conflicts comprise only non-state actors" (HIIK 2016, 14). The typology of conflicts is mainly divided into inter-state and intra-state conflicts. There has been a substantial difference in numbers between intra-state and inter-state conflicts 
since the end of World War II. The type of intra-state incompatibilities is divided into territorial and governmental issues. They are ordinary types of intra-state conflicts which have different levels of challenges to be resolved and thus secure lasting peace (Pospieszna and Schneider 2011, 8).

The type of territorial conflict occurs within a state territory and aims at replacing or sharing official control in a certain limited geographical area that longs for autonomy or independence (UCDP 2017a). The incompatibilities may be caused by a lack of political, economic or security representation or lack of fairer power-sharing issues between different groups (e.g., majority versus minority). Those issues might be based on ideological, ethnic, religious diversities or some kind of oppression, discrimination against minorities and unjustified distribution of income. In contrast, governmental conflicts encompass the entire scope of state territory. They arise from the urge to control the whole state, which means the political system of the government, the military, economy, justice, and the constitution. Governmental and territorial issues have often occurred since the end of the Cold War, but governmental conflicts have resulted in more fatalities than territorial ones (Pettersson et al. 2019).

Intra-state incompatibilities cause high numbers of casualties. Wherever a humanitarian disaster occurs, the United Nations Security Council bears primary responsibility for peacekeeping and likewise assumes an obligation guaranteed by International Law, the "responsibility to protect "(R2P) civilians (Bellamy 2009). However, a common consensus in the UN Security Council is required. As to the Syrian Civil War, $12 \mathrm{UN}$ resolutions were vetoed by Russia and China, which made a UN peacekeeping intervention impossible (Sciboz 2018). Similarly, as there was not any consensus in the Arab League, measures failed to prevent massacres in Syria, one of its member states.

Call (2012) laments the high number of casualties in civil wars. Countries having suffered from civil wars are more likely to face new civil wars according to statistics from the World Development Report 2011. The failure of peace settlements leads to renewed conflicts, as in Liberia. Consolidating peace in post-war countries is a tremendous challenge. According to Call, there is no single variable that accounts for success in consolidating peace and averting 
internal war recurrence. However, in matters of political exclusion, political or governmental power-sharing among parties is more essential than economic power-sharing.

\subsection{Peace and Peace Agreements}

A classic contribution to peace research was made by German philosopher Immanuel Kant, whose famous essay, "Perpetual Peace", makes us understand the timeline of peace conceptualization (Kant and Humphrey 1970). Kant aims at ensuring sustainable peace among states, involving people in government utilizing a republican, legal order. His thoughts and insights were strongly influenced by the circumstances of his time. Nevertheless, he built his framework of thought. According to Kant, sustainable peace at an international level can only be guaranteed through a generally applicable legal system, such as an international law respected by all participants. People's rights should be held sacred. Needless to say, his concept of international law has inspired the Charter of the United Nations (Friedrich 1947). He opposes interference in the internal affairs of other states and argues that the degree of hostility between conflicting parties should not go beyond a certain limit. He maintains that overstepping the limit of hostility would make future peace talks difficult and that a multilateral peace treaty would decrease armed conflicts between states. Politics should be based on morality.

A pivotal contribution to the concept of peace was made by Johan Galtung, (1969) who published his paper "Violence, Peace and Peace Research" in 1969. He approaches the terminology of "peace" and "violence" from a semantic and also ontological point of view. He has turned peace research into a novel field, conceptualizing, classifying and framing definitions of peace and violence, focusing on the different meanings of the two terms. He interprets peace as a social goal and as social order and defines it as an absence of violence. He emphasizes six crucial dimensions of violence: the distinction between physical/psychological, negative/positive, object/subject aspects, and intended/unintended and manifest/latent. Some factors overlap. He ascribes great importance to perceived personal and structural violence, giving concrete examples of his concept of peace (Galtung 1969, 177). 
Peter Wallensteen's concept of "quality peace" differs from Galtung's "absence of violence" (Wallensteen 2015). Wallensteen takes a historical view of traditional rivalries between various countries and peace solutions. These rivalries reoccurred because of changing pragmatic, political conditions in the past. To avoid recurrent conflicts, there can be some kind of exemplary intergovernmental unification such as the EU, which has created lasting peace. Ending wars may be achieved by military victory or peacebuilding agreements. However, peace needs certain post-peace-building regulations which cannot simply be realized employing peace-agreements (negative peace), but by quality peace. Quality peace depends on human dignity, security and predictability. They may prevent recurring wars in post-conflict periods in different ways and enable a sustainable, peaceful social world order. For instance, the conflict in Sri Lanka was resolved by a one-sided victory. However, incompatibilities in terms of human dignity are still there, which might entail new conflicts. In his definition of peace, Call (2012) values the perception of peace among societies. According to him, returning refugees are indicators of perception. However, perception of peace, war, stability, termination of the conflict, onset of peace, determination of periods are relative concepts.

As we can see, contemporary conceptualizations of peace through a formal social contract or an agreement between states on an international level are highly beneficial to sustainable peace. However, lasting peace should not be taken for granted. Lessons from the past should be heeded. The absence of a peace agreement after a ceasefire or failure to implement a peace agreement may generate a recurrence of armed conflicts in a post-civil war society. "A peace agreement is a formal agreement between warring parties, which addresses the disputed incompatibility, either by settling all or part of it or by clearly outlining a process for how the warring parties plan to regulate the incompatibility" (UCDP 2017a). It might be signed after ceasefire agreements or a long negotiation process through mediators or absence of mediators. It is an important formal step, a social contract to build peace and prevent the recurrence of civil wars in post-conflict societies. However, peace needs regular maintenance. Peace should be maintained employing justice, democracy, human right, welfare, "security, dignity and equity", respect, mutual integration in post-conflict societies (Wallensteen 2015, $16,21)$. In that sense, the support of third parties in post-conflict countries is important, as civil war-torn countries are unable to restore orderly conditions by themselves. 
Call (2012) tackles the question of why terminated conflicts reoccur in some cases but not in others. Due to the lack of previous research, this question can barely be answered. He points out that research work on that issue has long been neglected, as scholars, so far, have mainly focused on the character of agreements, on the degree of commitment among the parties, on state capacity and the effort made by third parties. In contrast, there are civil war cases that did not comprise any real peace agreements: Kosovo (1998), East Timor (1999), Afghanistan (2001), Haiti (2004) and Sri Lanka (2009). He criticizes the theory of "effectiveness of peacekeeping" as a tool for maintaining peace, while armed conflicts were still going on in Liberia, Haiti and East Timor after peacekeeping agreements. He is not so much concerned with short-lived ceasefires nor with their statistical analysis. He is most concerned with stable ceasefires lasting at least for one year. Moreover, it is generally believed that the failure to establish peace agreements leads to renewed conflicts, as in Liberia. To avoid any type of misunderstanding or expectations in post-conflict periods, peace agreements have to be achieved subtly. Inclusionary strategies such as the integration of former enemies into political or security institutions fully contribute to successful peacebuilding and peace consolidation.

By comparison, there have been ceasefires that finally resulted in successful peace agreements after some years. Basic provisions such as power-sharing, democracy and human rights were fully implemented. One could conclude that that type of peace agreement might ensure lasting peace to a higher degree than stable ceasefires. To enhance the successful implementation of such agreements, external support from international, regional or neighbour states is necessary.

Transitional justice provisions are important parts of peace agreements that promote sustainable peace and peaceful coexistence. Transitional justice as a response to the systematic violation of human rights aims to re-establish the rule of law after a violent conflict. It should be administered at the turning point of a conflict-ridden past to a new peaceful settlement. Democratic principles should be practised in a conflict between repressive regimes and heavily polarized members and victims of a civil war (Kritz 1995; Crocker 2000; De Brito et al. 2001; Vinjamuri and Snyder 2004; Lincoln 2011). Transitional justice concepts should be intensified in institutional arrangements to guarantee truth-seeking and legal protection of victims in postpeace agreement societies. To live again peacefully together, one should resort to new coping mechanisms. A new social contract such as a peace agreement should be established, aiming at 
comprehensive reconciliation utilizing judicial and non-judicial strategies and external third parties.

International and national institutions assume responsibility, seeking justice and truth through legal procedures. They have been dealing successfully with political events of great historical importance: the Nuremberg Trials after World War II, the International Criminal Tribunal for former Yugoslavia and Rwanda, the Truth and Reconciliation Commission (TRC) in South Africa in the aftermath of the Cold War (Crocker, 2000; Roth-Arriza and Mariezcurrena, 2006). The International Criminal Court, the UN, civil societies and NGOs have undertaken transitional justice initiatives which have led to some reconciliation in former conflict-ridden countries (Brahm 2006; Lundy and McGovern 2008; Gissel 2015).

The literature on transitional justice provides crucial evidence of how an unlimited level of hostility, crime, violation, rape and loss has traumatized and divided societies, making it difficult to establish peace and trust between perpetrators and victims in post-conflict eras (Barsalou 2008; Mendeloff 2009). Transitional justice is not a particular kind of justice, but rather justice tailored to the needs of communities changing a phase of widespread human rights violations (International Center for Transitional Justice 2009). Previous literature focusing on the interdisciplinary nature of transitional justice emphasizes similar aspects as peace research (i.e., prevention of conflict recurrence, post-war peacebuilding, lasting and quality peace) (Vinjamuri and Snyder 2004; Lambourne 2009). In the concluding surveys of a 2011 discourse in the Economist, 76 per cent of discourse respondent believed with the argument that peace can only be maintained by the implementation of justice (Binder 2013, 24).

The transitional justice concept has been complemented through a set of individual subcomponents such as reparation programs, return of refugees, criminal justice (prosecutions), land issues, past mechanism (truth-seeking commission), amnesty, judicial reform (national reconciliation), prisoner release, gender justice, policing (security system reform), memorialization efforts, victims, disarmament, demobilization and reintegration programs (TJPA Database 2017; Theidon 2007). In that regard, the Transitional Justice Peace Agreements Database facilitates comparisons between transitional justice arrangements in post-war countries over a certain time. Each above-mentioned section suggests various 
procedures for safeguarding the rights of victims and aims at preventing prospective human right abuses in post-conflict societies (Teitel 2000; Bell 2009; Pham et al. 2010; Lambourne 2009). This process is an important step to achieving reconciliation and restoring the dignity of war-time victims (ICTJ 2009).

"Victim" has been defined in the resolution of 40/34 of the United Nations (1985), the Declaration of Basic Principles of Justice for Victims of Crime and Abuse of Power. A considerable number of countries have become prime examples of repressions endured under authoritarian regimes, incompatibility and intense and long-lasting armed conflicts entailing immense suffering among the civilian population: Bosnia, Nepal, Timor-Leste, South Africa, Argentina, Rwanda, Iraq, Guatemala, El Salvador, Colombia, the UK (Northern Ireland), the Philippines, Sierra Leone, and DR Congo. From those post-war countries, one can see that the preferences of victims concerning transitional justice show disparities. According to the TJPA Database (2017), seventeen internal armed post-conflict countries included victim provisions based on reconciliation purposes of transitional justice from 1990 to 2007 (e.g., accountability; truth-seeking, compensation, rehabilitation of post-trauma syndrome, indemnification, social integration; memorial, amnesty) They are basic requirements for new cohabitation and reconciliation (Aiken 2010).

Modern studies of transitional justice attitudes toward victims distinguish between retributive (i.e., trials, punishments) and restorative justice (i.e., truth, reparation, amnesty) in post-conflict settings. Focus is placed on a victim-centred investigation in the post-war era of different countries. For instance, an evidence collection has been provided by Backer (2010) about violations committed during the apartheid regime in South Africa through "153 victims". These victims preferred punitive justice to amnesty, thus expressing pent-up frustration about the reconciliation commission and its inability to find out the truth. Another correlation between "victimization and demands for punishment and truth" is found in post-conflict Burundi (Samii 2011, 3). Pham et al. (2004) surveyed 2,074 victims who had been exposed to trauma in the Rwandan Civil War and who had witnessed genocide there. The result clearly showed that the victims preferred criminal justice. "More respondents supported the local judicial responses (90.8\% supported Gacaca trials and $67.8 \%$ the Rwanda national trials) than the ICTR $(42.1 \%$ in support)". Accountability is one of the most preferred mechanisms seeking justice. It was 
required by " $85 \%$ of respondents" in the post-conflict setting of Eastern DR Congo. Victims preferred "national trials (45\%), followed by internationalized trials in the DRC (40\%)" (Vinck et al. 2008, 2). Taylor (2015) likewise identified the "perpetrator accountability" among the victims' preferences in Colombia.

In contrast, victims in the Nepalese post-conflict society desire truth-seeking for the disappearance of people and demand financial compensation rather than a judicial process (Robins 2011). Victim preferences for compensation, reconstruction or reparation have often been provided as options in various post-conflict settings (e.g., Uganda, Georgia/Abkhazia, Ethiopia/Eritrea, Ivory Coast, Iraq, the Philippines) (TJPA Database 2017). The civil war in Guatemala resulted in the deaths of 200,000 people; thousands were wounded or went missing. The struggle for truth-seeking was a big issue in Guatemala, where victims urgently required comprehensive truth-seeking mechanisms rather than reparations and justice (Isaacs 2010). In contrast, Biro et al. (2004) refer to evidence given by post-war victims in Bosnia and Croatia (in the cities of Vukovar, Mostar and Prijedor in 2000 and 2001). They point out "that the level of traumatic experience did not correlate with seeking war crime trials, or with positive attitudes towards the ICTY: One victim: "things lost will not be returned to me, nor will this ease my suffering." Another survivor said: "The best thing is to let everything be forgotten. The greatest justice for me would be to let me live and die in peace there where I was born."

In comparison, an interdisciplinary contribution to the effectiveness of transitional justice mechanisms has been made employing public health investigation (e.g., trauma exposure and PTSD). If the healing process is to be handled effectively, social steps taken in the wake of severe abuse must consider the effects of trauma and deprivation (Pahm et al. 2004). The scope of discussion about transitional justice preferences of victims has been widened, as religious beliefs of victims are also taken into account. A positive correlation has been identified between religiousness and forgiveness (David and Choi 2006; Worthington et al. 2000). There have been mixed results as to victimization and preferences for transitional justice in various post-war countries. It is also important to assess the requirements of victims living in a city or the country.

Peace agreements aim at ascertaining the full truth, some even require that human right abuses which occurred during the civil war be rigorously investigated by reconciliation commissions. 
This is a difficult task, as members of parties would refuse to stand trial for war crimes and take responsibility for the past. In that regard, third-party mediators should strongly call upon the former warring parties to demonstrate social responsibility. External mediators can provide help to facilitate reconciliation processes. Reconciliation will enhance co-existence and create lasting peace in post-conflict societies. Pure mediators must make trials easier by having unbiased international judges, whereas power mediators must make use of pressure to establish commissions, in case parties should postpone or slow down their commitment. Further pressure on governments and rebel sides must be exerted by power mediators to hand over suspected persons who committed crimes against civilians. Multiple mediators must closely cooperate to find out individuals responsible for war crimes in order to practice transitional justice procedures without restriction. Moreover, multiple third parties should bear the financial cost of compensation for war-crime victims, mobilize NGO's for documentation and initiate the building of war memorials.

\subsection{Power-sharing Concepts and Arrangements}

The concept of the power-sharing idea primarily originates from the "consociational democracy" approaches developed by Arend Lijphart (1969). Jarstad and Sisk (2009) argue that power-sharing doesn't absolutely guarantee democracy. It applies to cases where certain rival actors or political opponents are excluded from power-sharing agreements. Power-sharing concepts and their purpose vary in governmental, territorial, economic and military issues. Numerous scholars have investigated the impact of power-sharing on democratic transitions, government formation, political institutions, autonomy, peace-building processes (Binningsbø 2013, 90-95). These issues are most commonly based on territorial and governmental issues in countries. To overcome those incompatibilities, strict implementation of various power-sharing provisions is indispensable in peace agreements.

The first few years just after the peace deal is ratified are very vulnerable, as the threat of conflict relapse often exists (Collier et al. 2013, 83). The large bulk of faults occur throughout the first two years (Melander 2009, 11). According to Joshi and Mason (2009, 1), around 52 
per cent of the "125 civil wars" that erupted in "71 countries" between 1945 and 2005 did not resurface. One might conclude that almost every second peace accord eventually failed in postagreement societies. The implementation of provisions aiming at sustainable peace is especially difficult in the early stage. It is important that peace agreements should be drawn up clearly without giving rise to misinterpretation. We know from present-day literature that powersharing propositions facilitate the initiation of negotiations between conflicting parties and have a positive impact on situational conditions. Hartzell and Hoddie (2003, 330) maintain that power-sharing is "guarding against implementation failure". DeRouen and Chowdhury (2013, 8) argue that "power-sharing provisions do not head off peace agreement failure or return to violence after peace agreements." Walter $(2002,17)$ identifies a close link between third-party security guarantees, power-sharing arrangements, and the peaceful resolution of civil wars. In terms of security guarantees, pure or power mediators have different skills to maintain security. As to the conceptualization of power mediators, they are more likely to be successful than pure mediators at providing security guarantees in an implementation period.

Walter argues that ending civil wars is a difficult task, as there is a permanent risk of recurrence in post-conflict countries in terms of "economic and political conditions". She explains, the antagonists are neither capable of decisively defeating the other nor capable of reaching and implementing mutually beneficial agreements. They are afflicted with a circumstance in which the parties are unable to settle their own disagreement (Walter 2011, 32-33). In such a case, third-party support for dispute resolution is extremely urgent, as sustainable peace can only be achieved employing skilful mediation. If governments of post-conflict countries do not strongly commit themselves to implement power-sharing agreements, respecting laws, building up democratic structures and strengthening the economy of the country, they cannot avoid renewed future conflicts. In a different study Walter $(1997,361)$ argues that "enforcement" mechanisms by third parties and "inclusive institutions" which guarantee pluralistic decision-making in political processes are necessary to implement peace agreements in short and long-term processes.

Jarstad and Nilsson (2008) examine utilizing a self-established dataset (IMPACT) to what extent the implementation of political, military and territorial power-sharing stipulations has led to lasting peace. They point out that "when the parties engage in costly concessions by 
implementing military and territorial provisions, the likelihood of peace prevailing is increased". In relations to this issue, DeRouen et al. $(2009,384)$ examine the impact of certain provisions (governmental, autonomy related and military power-sharing) on the duration of the time of peace. They conclude that territorial and military power-sharing is less hazardous than governmental power-sharing in terms of lasting intrastate peace agreements.

Binningsbø and Dupuy (2009) have conducted a case analysis in Sierra Leone to investigate the correlation between power-sharing provisions and the termination of the civil war there. In their study, power-sharing is positively related to the outcome of post-agreement peace in Sierra Leone. A further cross-country analysis - Angola, Somalia, Ethiopia and Rwanda - was conducted by Spears in 2000. In his study, he examines the discrepancy between theory and failed practices of power-sharing arrangements, closely analysing implementation processes and explaining why those agreements have failed. He concludes that the successful implementation of power-sharing is only possible if leaders are fully committed to maintaining peace and establishing institutions for that purpose (Spears 2000, 117). Walter (2002) likewise argues that the commitment problem is a hazard problem for a negotiated peace. Moreover, Mattes and Savun $(2010,511)$ emphasize the importance of credible "international monitoring" and "information asymmetries" between rival parties. They advocate the idea of an accurate design of peace agreements to prevent civil war recurrence.

Call (2012) further develops the theory of post-conflict peacebuilding and power-sharing procedures by emphasizing four approaches: Firstly, exclusion from the participation of other parties in politics, as security policy is more likely to engender war recurrence than economycentred approaches in previous theories. Secondly, the presence of third-party military troops maintaining stability once a ceasefire has been reached. Thirdly, "the legitimacy of post-war regimes vs. state-building”. Fourthly, understanding governance in post-conflict societies is expanded beyond electoral democracy to encompass different forms of distributing power and animate inclusion and participation. Power-sharing is the most prevalent form of inclusionary behaviour. In particular, power-sharing securely maintained by military and police forces provides crucial guarantees to alleviate fears of physical violence against demobilized fighters. That particular issue triggered war recurrence in Liberia, the Central African Republic, and East Timor. To avoid any type of misunderstanding or expectations in post-conflict periods, peace 
agreements have to be achieved subtly. It is maintained that inclusionary behaviour and the integration of former enemies into politics or security institutions closely correspond to successful peacebuilding and peace consolidation in modern times. In that regard, failed powersharing is harmful to lasting peace in post-agreement periods. Call (2012) investigates various cases, starting with Liberia, which provides a perfect example of Charles Taylor's exclusionary behaviour (e.g., lack of political power-sharing, repression of political opponents). It also underlines the correlation with civil war recurrence.

The UCDP Peace Agreement Dataset is based on "5 main characteristics of the peace agreement: these are provisions on military, political, territorial, justice matters and, finally, provisions concerned with the implementation of the accords." (Högbladh 2011, 44). They include ceasefire, integration into the army, DDR, withdrawal of foreign forces, regulation of violent behaviour exhibited by party members in terms of governmental incompatibility regulation. Consequently, rebuilding a well ordered state based on democratic principles requires many provisions: political party (right for rebel groups to found a political party), integration into government/civil service, elections, interim government (rebel integration into the interim government), national talks to solve incompatibility, power-sharing in government, political provisions regarding the regulation of territorial incompatibility: autonomy, federalism, independence, referendums, local power-sharing, regional development, cultural freedom (language in schools, flag, anthem), border demarcation, local government, territorial provisions, amnesty, release of prisoners, national reconciliation, return of refugees, justice (ibid. 2011).

I argue that we still know very little about external factors such as third-party mediators promoting or hampering the implementation of power-sharing provisions in post-agreement processes. As third-party mediation occurs in different short-term peace processes, it should also support the implementation of power-sharing that has been reached so far. In this context, third parties have different identities, qualities and quantities. Pure mediators are more able to provide communication and facilitation between rival parties, whereas power mediators often make leverage parties to reach and implement an agreement. Therefore, both types, pure and power mediators, are likely to provide power-sharing implementation at different levels of success. 
Security power-sharing agreements such as disarmament, demobilization, ceasefire, the formation of new police forces can be best put into practice by power mediators, as they have the military capacity to leverage hostile parties and provide professional personnel to support the implementation on the ground, whereas pure mediators help to establish confidencebuilding which can increase trust-building. Pure mediators use their communication skills (e.g., persuasion) to gain support for the peaceful existence of rival parties. Another challenge for both types of mediators is the scope of power-sharing responsibilities during the implementation process. If certain mediation players (pure or power mediators) are more strongly represented in the field, they will be able to better monitor ceasefire processes, identify peace-spoilers, organize disarmament, demobilization and reintegration of ex-fighters, facilitate returning IDP, initiate judiciary reforms and finance the peace process. If a single pure or power mediator were to strive for the implementation of all those provisions, he would certainly be overburdened due to the large scope of responsibilities. This would inevitably entail failure. Moreover, the mediator's credibility would be highly questioned. Another failure of a single mediator is likely to occur if he is interested in the implementation of specific powersharing such as governmental power-sharing in parliament between rival parties but not in security arrangements in peace agreements. As a general rule in designing peace agreements, the presence of foreign peacekeeping troops has got a limited schedule to stay. They will have to leave when their time is over if the duration of their stay has not been extended by governments, regional organisations or the United Nations. Peacekeeping personal might be provided by third countries. This can happen if single third parties have their own secret political or financial agenda in the post-conflict country concerned. In contrast, multiple third parties can block each other by following such secret agendas.

A single pure or power mediator has limited skills according to previous conceptualization. For instance, a regional organisation can provide very good diplomacy between parties to implement disarmament of rebels and integrate them into the new governmental security forces. If technical and legal assistance or financial support is not sufficient, the security power-sharing can fail as well. Or if the pure single mediator does not have monitoring personal on the ground, the failure of implementation is unavoidable. 


\subsection{International Mediation}

What does international mediation mean? What is its aim in a peace agreement implementation process? Based on historical, national and local experiences of mediators in different places of the world, international mediation has been conceptualized differently. Mediation is a historical phenomenon that occurs between warring parties to solve incompatibilities employing thirdparty support. Third-party conflict mediation is based on the theoretical framework of peacemaking, peacebuilding, peacekeeping and conflict resolution and is considered a crucial tool for ending intra-state conflicts. Bercovitch and DeRouen (2004, 153-154) state mediation as a dispute-management phase, where the contestants desire the help of an individual, party, nation or institution to resolve their disagreement without recourse to physical violence.

To the present day, research facilities and third-party mediation have been particularly developed within the scope of intrastate conflict resolution. Mediation plays an important role in peace and conflict transformation periods. Third parties might be international or regional organizations, NGO's, states, universities or eminent personalities (UCDP 2017a). The strategy of mediation can be either "communicative/facilitative, procedural" or "directive" (DeRouen et al. 2011, 665-666). These mediation approaches differ from third-party peace initiatives in terms of power, interest, circumstances, culture, history, the intensity of conflict, and the willingness of conflicting parties to cooperate.

In the course of the last years many scholars have been conducting research on international mediation (Frei 1976; Zartman and Touval 1985; Stedman 1991; Sisk 1996, 2009; Bercovitch 1996, 2011; Kleiboer 1996; De Soto 1999; Walter 2002; Bercovitch and DeRouen 2004; Doyle and Sambanis 2006; Zartman 2007; Savun 2008; Clayton 2013; Wallensteen 2011; Wallensteen and Svensson 2014). They all focus on mediation effectiveness and conceptualize mediation success differently from each other. Some researchers merely focus on the effect mediation has on intrastate conflicts, on how mediation can lead to a ceasefire or a peace agreement between the conflicting parties. The relationship between short-term mediation success and conflict termination has been eagerly debated. Less attention has been paid to long-term mediation in intra-state conflicts, post-agreement peace in connection with implementation processes. Some 
studies dealing with long-term mediation reveal that the successful implementation of peace agreements is due to successful mediation (Bercovitch and Simpson 2010, 73). Accordingly, one might assume that long-term mediation is a solid base for keeping and supporting peace in post-agreement periods. The concept that peace agreement processes can indeed be successful through long-term mediation effort is shared by Bercovitch and Simpson (2010, 94-95). Situational factors should also be taken into account. Long-term mediation units have special tasks during implementation processes, as stated below.

A fundamental question about long-term mediation and post-conflict societies is raised by Call (2012, 237): Can external actors build legitimacy after the war? He argues that external actors play a positive role, enhancing inclusionary behaviour and legitimacy-focused peacebuilding, despite the limits and perils of recurring civil wars. He defines four temporal junctures for postconflict societies regarding the transition from warfare: the decision on what structures and which individuals will rule for an interim period, the long-term design of the state, elections and the end of an interim administration and the post-electoral period. There might be a great deal of conflict potential in the first years after the election, which is seen to mark the end of a transition from war, as there might be the danger of war recurrence.

All in all, the crucial conditions to prevent the recurrence of civil war in post-conflict societies should be duly considered because they bear a striking resemblance to implementation conditions during a post-agreement period. They are factors that facilitate or hamper mediation effectiveness: political-governmental, economic and security power-sharing, state capacity, electoral democracy, presence of third-party military troops maintaining stability, DDR programs, social factors, ethnic diversity and integration, repression of political opponents, state weakness, external factors from neighbouring countries leading to recurrence of civil war. Third-party mediators should always consider these factors to enhance proper implementation over a long time. In the following, the quantity, coordination and type of external mediators will be discussed, since external mediators bear full responsibility for the implementation of peace agreements. 


\subsubsection{Power Mediators and Pure Mediators}

The conceptualization and characteristics of conflict mediation in terms of communication skills (e.g., persuasion) and leverage effect (e.g., coercion) have been interpreted differently by scholars and therefore classified accordingly (Bercovitch and Rubin 1992; Beardsley 2009). Power mediation and pure mediation have been classified by Zartman and Touval (1996) as follows: "Power - the ability to move a party in an intended direction - is often referred to in mediation as "leverage". The "powerless" or "pure" mediator, however, is to persuade parties lacking leverage to communicate more easily with each other (Zartman and Touval 1996, 436-439). A similar distinction between the two types of mediation for conflict resolution is made by (Ramsbotham et al. 2011). They argue that power mediators possess sufficient power to have a significant influence on parties and negotiations. In that regard, major powers, such as the members of the UNSC, are likely to be effective in the conflict prevention of minor conflicts, as they have military and economic capacities (Melander et al. 2009). On the other hand, powerless mediators are supposed to open lines of communication and assume facilitation responsibility (Ramsbotham et al. 2011, 23). These types of mediation can result in different outcomes in intra-state conflicts depending on conflict environments, power of conflicting parties, cultural backgrounds, incompatibilities, power-sharing contents or intensity.

Due to the large variety of different statements, an empirical analysis of "pure" and "power" mediation in civil wars was undertaken by Svensson (2007). He points out that power mediation may be preferred by parties in internal armed conflicts which require particular security guarantees such as sponsoring post-agreement implementation processes, monitoring proper power-sharing and fair elections. He examines the impact of pure versus power mediators in terms of reaching a peace agreement with specific provisions based on territorial, governmental and military power-sharing in internal armed conflicts.

\footnotetext{
"Power mediators are defined as mediation efforts by great powers, colonial powers, and neighbouring states, whereas mediators who are representatives of international, regional, or non-governmental organizations, individuals, and small and distant states, are classified as pure mediators" (Svensson, 2007, 230).
} 
In terms of political, territorial and military power-sharing, the type of pure versus power mediation yields different results. "Pure mediators tend to outperform power mediators in terms of getting agreements with provisions for political and territorial power-sharing [...] Power mediators are particularly suitable for reaching agreements where the military power is regulated" (ibid. 231). Investigations of numerous international mediators engaged during and after armed conflicts have shown that some countries employed "pure" mediators (e.g., El Salvador, Guinea-Bissau, Indonesia, Philippines and Sierra Leone), whereas others had recourse to power mediators (e.g., Northern Ireland (UK), Lebanon, Bosnia, and Mali). According to Svensson, a combination of pure and power mediators has yielded better results in conflict resolution than the use of a single, one-type mediator (Svensson 2007).

International and regional organizations are supplying external security guarantees in pre-and post-agreement peace affairs as "pure" mediators. Although the UN's objective is to keep peace in civil war-torn countries, its peacekeeping missions have sometimes failed in countries such as East Timor, Rwanda, Somalia (Ghoniem 2003, 11, 21; Doyle and Sambanis 2006, 24, 157) or UNPROFOR in Bosnia-Herzegovina concerning the Massacre of Srebrenica (Karakus 2015a, 47). The role of UN peacekeeping forces in the modern world is multifaceted. The following survey shows how many mediated peace accords were achieved due to the intervention of UN peacekeeping forces from 1989 to 2012, Angola, Bosnia, Burundi, Cambodia, Croatia, Ivory Coast, Liberia, Mozambique, Rwanda, Sierra Leone, Sudan, and Timor-Leste (East Timor). 12 out of 26 mediated peace-agreement cases encompassed UN peacekeeping force mechanisms (Joshi et al. 2015). Almost half of them adopted the UN peacekeeping force mechanism which decreases aggression and makes it easier to enforce the deal (DeRouen and Chowdhury 2018).

Nations such as Liberia, Sierra Leone and Burundi have acquainted themselves with the role of UN international and regional peacekeeping forces (e.g., ECOMOG-ECOWAS). Regional peacekeeping forces have the same responsibility as UN peacekeeping forces and are committed to maintaining unity and trying to reach a peace settlement (Joshi et al. 2015). The international (UN) and regional security of external third parties mostly facilitated implementation processes. At the same time, the sponsoring of implementation processes by third parties is indispensable. Successful implementation also depends on how strong the country's economic power is. 
Both types of mediation have been closely examined in pre-peace agreement processes in terms of conflict termination. Nevertheless, there is still a wide research gap left in post-agreement processes as far as the two mediation types are concerned. In that sense, the role of pure mediation facilitating "direct negotiation" has not yet been adequately examined. According to Harris and Reilly, "pure mediation involves the use of process skills, techniques and experience to urge the parties on, or ease their path, towards a solution which they design, re-fine and ultimately implement." However, power mediators can dominate parties and drive them into a negotiation process: The power mediator has the power to apply appropriate sanctions to ensure that the agreed-upon outcomes have been achieved and that conformity is maintained (Harris and Reilly 1998, 108-110). The conceptualization of power mediation is extended by Heemsbergen and Siniver $(2011,1172)$. They "propose a heuristic framework which entails a typology of four distinct 'routes' to power mediation, defined here as real, made, critical and structural". The power mediation type is associated with the approaches of international relations such as neo-realism associated with "real power", constructivism with "made power", structuralism with "structural power", idealism with "critical power".

Nathan $(1999,3)$ points out that third-party mediation with "muscle" is supposed to be a risky strategy to deal with internal conflicts. He attaches importance to confidence-building between parties in the first place: "The emphasis is on facilitating dialogue and joint problem-solving rather on pressuring the disputants to settle. The reasons for adversaries' resistance to negotiations are referred to as "psycho-political dynamics'." This aspect is certainly a highly sensitive issue in pre-peace processes and might be difficult to handle by mediators and rival parties concerned. Admittedly, both types of mediation can be diligently balanced and carefully evaluated by mediators in an implemented post-agreement peace process. Transitional justice procedures of peace agreements (Truth and Reconciliation Commission) will always involve highly sensitive implementation processes.

Based on the four selected countries, the impact of the two types of mediation will be analysed within a time frame of 10 years to find out to what extent the two types of mediation have facilitated or hampered the implementation process of peace agreements. The results might open up new ways to critical discussions about the concept of power and pure mediation. Power 
and pure mediation have scored high and low implementation in this thesis. This discrepancy is to be examined in close comparative case analyses. One might be inclined to assume that specific names or identities of power and pure mediators largely determine the success of the implementation. Svensson $(2007,231)$ points out that "pure mediators" succeeded in reaching agreements, whenever "provisions for political and territorial power-sharing" were largely granted. In contrast, military power-sharing provisions were mainly achieved by power mediators. According to Svensson, such differences as to provisions achieved in implementation processes can only be accounted for by the specific nature of power and pure mediators (ibid. 246). His highly revealing observations lead to the question to what extent power and pure mediators can enhance successful implementations of peace agreements.

I argue that one can draw a clear line between conflict termination and implementation processes. Both types of mediation possess certain characteristics, skills and qualifications. They therefore can contribute to successful peace agreement implementations, each in their way. A certain type (power or pure mediation) with different skills would be desirable in postagreement countries, as they might considerably enhance the success of the implementation. It might be possible that both types of mediation positively influence provisions in terms of governmental, territorial or security power-sharing. Pure mediators are international and regional organizations such as the UN, the EU, ASEAN, the African Union or the OSCE. The same applies to power mediators between neighbouring or powerful states. There is also the question of whether external pure and power mediators are seriously interested in implementation processes and whether they are accepted as peace-brokers by rival parties. Melin and Svenson (2009) take a clear stand on this, as they differentiate between interstate conflicts and intrastate conflicts. They claim that the political price of endorsing "international mediation" would be far more in "civil wars" than it does in "international conflicts".

Another concern has been raised over the conceptualization of mediator types in terms of skills, quality and power. As both types largely vary in their characteristics, their different skills can be successfully combined into implementation processes. As the UN and regional organizations are classified as pure mediators (persuasive), they can be power mediators as well. On the one hand, the UN can facilitate land-sharing between the government and rebels on the table, on the other hand, it can provide security personal on the ground to set up lines or buffer zones. 
In that regard, the peace-building interest of organizations, mandate time, financial support and number of available peacekeeping personal for implementation should be taken into account. The UN, the African Union, the ECOWAS, the Arab League have a military (i.e., leverage) and economic power and can replace a power mediator. Therefore, short-term conceptualization (conflict termination and effect on power-sharing agreement) and skills of power mediator can deviate in long-term implementation periods. The power mediators can use communication and facilitation skills without the necessity of military enforcement in implementation processes as well. Therefore, the quantity and quality of both types should be considered during the implementation process. They might have a different impact on governmental, territorial, economic and military power-sharing implementation. However, I still believe that the leverage effect of single power mediators is strong to prevent ceasefire violations, implementation of security provisions as it can swiftly employ military personal and equipment on the ground. The single pure mediator UN can be different from other pure mediators such as the Organisation of Islamic Cooperation or ASEAN as they do not have any military capacity. That means within pure and power mediation units, the skills and effectiveness for implementation success can vary. In the following, strategic coordination of mediation is introduced to show to what extent the quantity of mediators makes sense for conflict termination in internal conflicts and thus for implementation processes.

\subsubsection{Multiparty Mediation and Single Mediation}

A comprehensive analysis has been conducted in terms of strategic coordination in armed conflict mediation. The role of single mediators and one of the multiple mediators between locals, states, regional or international organizations have been widely discussed by numerous researchers (Crocker et al. 1999; Jones 2001; Walter 2002; Herrhausen 2007; Svensson 2011; Beardsley 2011; Böhmelt 2012; Vuković 2015; Menninga 2015). Böhmelt (2012, 713) emphasizes the double-sided effectiveness of multiple mediators. They have different strength and weaknesses, fully bearing responsibility for conflict termination. He points out that a coalition of mediators can share labour, bear responsibility in coordination and use joint, strong leverage. In contrast, mediation coalitions might display weaknesses: "States may face the more 
difficult cases here, or they might signal to other actors that their economy is weak or that they highly value the accountability of their regime type." Vuković $(2015,66)$ argues that legitimate multiple mediation efforts by neighbouring states were successful in the case of Tajikistan. Mediation there was coordinated by the UN. In terms of single versus multiple mediators, success is also measured by duration, over several years. Beardsley $(2011,129)$ emphasizes that single mediators may outperform multiple mediations in the long run. Negative outcomes are often caused by a lack of coordination between multiple mediators.

Stedman et al. $(2002,94)$ points out that about "200 official and unofficial actors" intervened in the Burundi peace-building process between 1993 and 1995. It has been argued that stubborn refusal to respond to requests from the other side may give rise to peace spoilers there, generating physical violence. That was the case in "Bosnia, Rwanda and Burundi" (Stedman 2002, 90). Consequently, as far as proficient coordination is concerned, "clear leadership" and a stringent calculation method of priorities are indispensable (Von Hehn 2011, 388-389; Urbain 2017, 87). Inadequate teamwork is generally observed by political representatives including local administration in obtaining very „different messages“ from a multitude of UN agencies. In contrast, mediation in coordination with UN authorities has produced good results (Stedman 2002, 110).

Stedman (2001, 14) argues that half-hearted attempts at peacebuilding were made by international or regional powers in conflict-ridden countries, such as Somalia and Rwanda. As long as the conflict environment and its impact zone were geographically limited and did not pose a serious threat to the integrity of the whole country, international or regional powers refrained from full political or military intervention. As regional and international powers are, in general, well experienced, militarily and financially strong, their involvement is of great importance: In either particular circumstance, the efficacy of implementation would be significantly diminished without appropriate cooperation by the UN, a related regional or international agency, or a capable state (Stedman et al. 2002, 112). Walter $(2002,15)$ noticed that about half of the fighters having authorized substantive arrangements for peace in the 19401992 era wanted to go back to fighting instead of incorporating the provisions of the accord. 
Svenson $(2017,86)$ investigates the effect of multiparty mediators dealing with conflict termination in internal conflicts. He argues that combining different qualities of biased and unbiased mediators might result in a successful mediation, as they have different skills to access information and its flow. As the necessity of mediation coalitions in the implementation of peace agreements has been widely overlooked, there is a need to investigate the power or pure mediation types. Multiple power or pure mediators might be more likely to enhance the successful implementation of peace agreements than single power or pure mediators. One might assume that coalitions consisting of the UN and mediators from peace-supported countries should be far more successful than a random single mediator from a single state, regional and international organization. A coalition of multiparty mediators has different skills in dealing with conflicting parties. Besides, the UN has ample military and financial capacity, political power and a great deal of experience in this field. Due to its large enforcement power, it can solve the "commitment problems" of conflicting parties more easily (Walter 2002, 15).

Jones $(2001,23)$ points out that post-conflict environments are highly challenging. In that sense, the high number of mediators might be justified to facilitate a peace-implementation process, provided that mediators work together in a coordinated manner, given specific implementation provisions (e.g., civilian security, policing, refugee resettlement, human rights, elections, economic reconstruction and development, governmental power-sharing in an interim government). However, if coordination fails among third parties, in case of overlapping responsibilities, incompatible priorities or subdued interest, implementation processes are also bound to fail.

I argue that multiparty pure mediators or power mediators in cooperation could outperform single mediators in the implementation process of a peace agreement. They will be more able to share implementation tasks and tools than a single mediator to support parties. If a single mediator has limited personnel on the ground or limited technology to monitor ceasefire implementation, the peace spoilers will take advantage of an opportunity to disturb peace implementation between the contracting parties. This could be prevented by multiple mediators as one would have proper peace-keeping personnel and the other one technology. In the implementation process, commitment problems are likely to emerge between parties. They can be solved more easily by multiple international, regional organizations or credible personalities 
as they might have different skills, styles, and communication channels between parties to persuade them. They are more capable of motivating local people, reaching distinguished local personalities to pressure the government or rebel groups into keeping the implementation process going. Implementing the disarmament of rebels requires a higher level of trust between mediators and rebel leaders. The trust-building process might have gone wrong with a single mediator if it failed to provide a security guarantee. The second or third mediators could repair the mistakes of the past and set up a new relationship on a long-term basis. The mediators can cooperate to create a new expert group that is professionalized in the disarmament program and sophisticated in suspending legal proceedings of former fighters after the implementation of disarmament.

Commitment problems to peace can emerge by single mediators in the run as well. Providing implementation assistance by single mediators could be limited if their mandate is not extended, financial support is not granted anymore, or if a single country does no longer take interest in the peace-building process in other countries due to internal political change. On the one hand, one president can be fully committed to the sustainable peace process in other countries, whereas the new president is not. To avoid such cases, multiple mediators could be a replacement of the missing support for implementation.

\subsection{Mediator Tasks for Implementing Peace agreements}

In the following, the light will be shed on special tasks of mediators in terms of implementing peace-agreements. These major tasks have been selected from the previous pieces of literature and the Peace Accord Matrix (Stedman 1997, 2002; Nathan 1999; Hartzell et al. 2001; Walter 2002, 2011; Hoddie and Hartzell 2003; Fortna 2004; Bercovitch and Simpson 2010; Pospieszna and Schneider 2011; Joshi and Darby 2013; DeRouen and Chowdhury 2013; Joshi et al. 2015). They are complementary to each other and are to enhance successful implementation. They can be provided in a different manner by pure and power, single and multiple mediators in longterm power-sharing peace processes:

- Monitoring and verification 
- Sponsoring and donor support

- Resolution of dispute and commitment problems

- Security guarantees, enforcement and confidence building

- Combating peace spoilers

- Implementation timetable

\subsubsection{Monitoring and Verification}

Third parties such as international and regional organizations, NGOs, single states or institutes are in charge of monitoring post-agreement peace processes. Verification of an implementation process is closely monitored in terms of a special task force. Focus is set on whether the conflicting parties perform their agreed duties as part of the peace agreement provisions, such as elections or the release of prisoners according to a detailed implementation timeline.

The monitoring task might be fulfilled by the same third-party mediating in the pre-agreement peace process or by a new third party that is active only in the implementation period of the agreement. Monitoring provisions is a difficult task. One could even say it is performed by an external actor. It involves official invitations, legal status and creates a tangible framework for the monitoring team. 20 out of 26 mediated peace-agreements cases included monitoring provisions (1989-2012) (Joshi et al. 2015).

A large number of cases of civil-war torn countries confirms the necessity of a third-party monitoring mechanism aiming at the verification of the implementation of various governmental and territorial power-sharing provisions. Although 20 of the above-mentioned cases comprise monitoring provisions, the degree of implementation score largely differs between low and high over ten years. Pure or power mediators such as the UN, NATO or individual countries as mediators meet the needs of monitoring and verification differently. Some post-agreement countries insist on monitoring mechanisms to protect civilians and have security structures rebuilt in post-war periods. The absence of monitoring mechanisms during an implementation process might make it impossible to find out which party has not fulfilled its commitments. It is difficult to prevent violations of agreements due to a "commitment 
problem" (Walter 2002, 15). The absence of a third-party monitoring mechanism or third eye might lead to a failure in peacebuilding.

I argue that monitoring and verification mechanisms provided by third-party mediators at a time when power-sharing is implemented are important to enhance the peace process. The provisions in the agreement are supposed to be implemented within a certain time and the third party regularly monitors their implementation. If the implementation progress slows down or is postponed by one side, the third-party urges the conflicting parties to proceed with the implementation process. That way, leverage power, communication and facilitation skills are exerted by both, pure and power mediators. Pure mediators can enforce communication between opposing sides, whereas power mediators can put massive pressure on parties. However, if monitoring and verification tasks are shared between multiple third-party mediators in a post-conflict country, enhancing implementations will be more successful. It means that the number of third parties is essential.

\subsubsection{Sponsoring and Donor Support}

The civil war countries are generally exhausted in terms of economy, security and functioning government system. Lack of economic strength makes it difficult to rebuild a country and finance the implementation of peace agreement provisions in terms of a fair electoral process, emergency programs for the reintegration of displaced persons, refugees, justice system, education system, health care, disarmament, demobilized soldiers, rehabilitation and reconstruction, restoring the national economy, modernization and professionalization of the public security system. Only some post-agreements countries were given financial aid because there was a "major or regional power interest" in those countries, which led to successfully implemented peace-agreement processes (Stedman 2001, 11). External countries as well as multinational organisations are encouraged to contribute financially to the execution of the negotiated peace, as stated in the agreement (Joshi et al. 2015). 16 out of 26 post-agreement countries received financial donor support: Burundi, Cambodia, El Salvador, Guatemala, Liberia, Macedonia, Mali, Mozambique, Niger, the Philippines, Rwanda, Sierra Leone, Sudan, Tajikistan, and Timor-Leste (ibid. 2015). 
I argue that the lack of sponsoring and donor support for implementation can negatively affect the implementation progress. The implementation process of provisions needs to be financially supported by external countries or international donors. In that sense, the donor support of thirdparty mediators is a key factor. Mediators can organise an international donor conference to invite donors for the country concerned. The pure or power mediators have different networks and connections with countries, regional and international actors. A coalition of third parties sponsoring the implementation of a peace agreement would be most desirable.

\subsubsection{Resolution of Dispute and Commitment Problems}

Although implementation processes are financially sponsored by organizations or single states, disputes due to a "commitment problem" sometimes occur between rival parties during the implementation period. Dispute resolution mechanisms are therefore compulsory (DeRouen and Chowdhury 2013). The credible commitment problem is one of the factors which endanger negotiations and the post-agreement implementation period. That means "even the combatants reach a mutually agreeable bargain, they will not implement its terms unless credible guarantees on the terms of the treaty are included" (Walter 2002, 8). They are concerned about a safe demobilization process without any attack from the rival side and want power-sharing to be guaranteed (ibid. 26). To overcome credible commitment problems or further postponement obstacles during a peace-agreement implementation process, credible external enforcement mechanisms are required in the long run to put pressure on the conflicting parties.

They are urgently needed between conflicting parties showing disdainful distrust for each other and having very limited communication channels. This kind of assistance is provided by third parties such as regional security organizations, peacekeeping units or individual nations. For instance, during the implementation of the peace process agreement in post-war Bosnia, NATO alone shouldered the responsibility for the "international police force and an internationally appointed High Representative for civilian affairs" (Wallensteen 2012, 294). Legitimacy was granted in compliance with the Charter of United Nations, "Chapter VII: Action with respect to threats to the peace, breaches of the peace, and acts of aggression" (United Nations Chapter VII) (UN 2017). 
An unsettled dispute or commitment problem might cause damage in an implementation operation. It might even seriously violate a peace accord. That was the case when the "two worst humanitarian emergencies of the 1990s in Angola and Rwanda in 1994" occurred. They resulted in a high number of casualties (Stedman 2001, 20). An external third-party as a dispute resolution authority can perform long-term mediation, as in reaching a ceasefire, calling on the "Council of Elders and Religious Leaders for resolution" to reach a peace deal (Lomé Peace agreement), looking for resolution through mediation, arbitration or court (Bougainville Peace Agreement, Accra Peace Agreement).

Dispute resolution should be provided by external mediators (pure or power mediator) having power, influence and experience in intervention capacity. However, those mediators sometimes fail to prevent disputes in post-implementation processes, although short-term mediators have done their best to facilitate communication between conflicting parties and even have had them sign an agreement. "Domestic commission (national, sub-national, or local) can be set up to solve disagreements that arise during the implementation process. The focus of these bodies is the implementation of the accord and the channelling of conflicts through institutions" (Joshi et al. 2015). The following 15 countries accommodated a dispute resolution provision: Angola, Bosnia, Burundi, El Salvador, Indonesia, Ivory Coast, Lebanon, Liberia, Mali, Mozambique, Niger, Sierra Leone, Sudan, Tajikistan, and the United Kingdom (ibid. 2015). As powerful states and international organizations such as the UN, the African Union, the EU and NATO have such enormous potential, they should responsibly extend their political and economic influence.

I argue, as the conflict causes are different in countries, various disputes in terms of economic, security or governmental power-sharing might emerge during the implementation period of stipulations. In terms of dispute resolution, pure and power mediators can use different skills to solve incompatibilities. If the implementation procedures of specific provisions are not clearly stated in detail (farmland sharing between former rebels and government, returning Internally Displaced People to the area, disarmament schedule for rebels), the parties involved might interpret them to their benefit. So, expectations in dispute cases might largely differ. This problem can be solved through subtle communication skills displayed by pure mediators or 
strong leverage applied by power mediators. In the case of ceasefire violation, a power mediator could be more assertive than a pure mediator, as he might be able to use military power. In contrast, a commitment problem or postponements of implementation can be solved by pure mediators using their communication and facilitation skills or applying economic sanctions. All in all, multiple pure or power mediators will be more effective to persuade parties to fulfil their promises. Different responsibilities of dispute resolution can be shared easily by multiple mediators. However, it should be noted that certain mediators (pure or power) enjoy more respect and trust in dispute situations than others on account of their high level of assertiveness based on previous experiences and reputation.

\subsubsection{Security Guarantees, Enforcement and Confidence-Building}

Confidence-building measures and associated stipulations in peace agreements pave the way to building trust and "security" between conflicting parties at the time of a ceasefire or peace agreement process (Hopmann 2000, 572). They could be referred to as violation preventing mechanisms, such as the release of prisoners, jointly controlled checkpoints, information exchange, and establishing a mutual local court, etc. Accordingly, confidence-building measures play an indispensable role in successfully implementing ceasefires and peace agreements.

Military power-sharing, demilitarization, reintegration of rebels into national army forces and parliaments after peace treaties are likely to create a favourable confidence-building environment. Peace agreements include military reform provisions for confidence-building. „The accord calls for changes in the structure, leadership, or composition of the national armed forces, changes in training procedures; civilian control over the use of the military; the integration of opposition troops into the national army“ (Joshi et al. 2015). Several postagreement countries have reintegration provisions in their peace-agreements. Reintegration processes aim at normalization, the demilitarization of ex-fighters and their integration into civil life. They are, in particular, beneficial to traumatized child soldiers, assisting them psychologically. 
Confidence-building measures such as disarmament, demobilization and reintegration (DDR) programs and military reform provisions could be positively associated with lasting peace agreements. Lack of confidence-building provisions might diminish trust between parties. Mutual trust is considered the key focal point in post-agreement processes. Lacking trust hampers the efforts of mediators. It might even impair the entire implementation process (Arnault 2006, 15).

Third-party "security" protections and "power-sharing pacts" are the two most critical aspects in persuading adversaries to agree and pursue peace agreements. Then will we be able to coexist (Walter 2002, 17). Third-party security guarantee keeps implementation processes safe in a long-term time. According to Joshi and Darby $(2013,268)$ third party security "existed either in the form of a UN Observer Mission, as in El Salvador, or a UN Transitional Authority, as in Cambodia". The third-party security factor is to solve any commitment problem between parties in case of doubt or uncertainty. Mattes and Savun $(2009,752)$ point out that "the presence of third-party security guarantees decreases the likelihood of renewed conflict by $69 \%$ ". Svenson (2009, 464) emphasizes the positive correlation between third-party security guarantee and lasting peace. He claims that security guarantees prolong and improve the durability of postagreement peace. However, according to Pospieszna and Schneider (2011, 17), third-party security guarantees do not contribute significantly to assessing long-term mediation effectiveness. Walter emphasizes that "third-party security guarantees" give motivational power to implement agreements (Bercovitch and Simpson 2010, 75-76). According to Walter (1997, 360), while mediation is simple to use and easy, merely having clearer intelligence and improved diplomatic relations between local rivals does not seem to be adequate to resolve major security challenges. The mediation will not be able to persuade groups to make agreements without preceding security guarantees.

Enforcement doesn't necessarily mean military enforcement or threatening others to impose mechanisms involving violence. It refers to an operating principle that encourages "compliance" and cooperation between parties. "Transparency", "bureaucracy" and conflict resolution tasks facilitate missions of enforcement mechanism. In case the implementation process is blocked by one side, a light political or economic "sanction" might give a fresh impetus to the derailed peace process (Ouellet 2004). The task of conflict resolution mechanism 
is also related to third-party responsibilities such as monitoring, dispute-resolution, confidencebuilding and verification mechanisms. Pure or power third parties are essential factors, as they contribute to enhancing the quality and environment of implementation work.

Fortna $(2004,288)$ emphasizes that foreign assistance involvement is not an ultimate solution; it does not ensure permanent peace in either occasion, but it does achieve peace more likely to last. According to Fortna's Peacekeeping List, peace accords based on UN enforcement missions and other regional organizations were accomplished in the following cases (19671995): Congo/Zaire, Georgia-Abkhazia, Haiti, Iraq-Kurds, Iraq-Shia, Liberia, Rwanda, Sierra Leone, Tajikistan, Yugoslavia-Bosnia, and Yugoslavia-Croatia (ibid. 289-290). Similarly, a positive statistical correlation has been identified between third-party enforcement and peace maintenance after civil wars (Hartzell et al. 2001, 199). In South Africa and the Philippines, peace agreements were successfully implemented despite the absence of an external enforcement mechanism (Hoddie and Hartzell 2003, 316). However, the implementation score of the peace agreement in the Philippines is low. There is concern that the peace accord might be violated in the future. This goes to show that the requirement of external enforcement mechanisms is related to various factors such as the quality of agreement or post-conflict conditions.

I argue that the promotion of security guarantee, enforcement and confidence building can be differently enhanced by pure and power mediators during the implementation. One the one hand, pure mediators such as the UN, African Union or NATO can take full responsibility in the post-war country. They can send peacekeeping military forces to ensure security and help for confidence building in the society. The quantity and duration of peacekeepers play an important role during the implementation process. Shortage of staff and failing interest in external mediators can be hazardous to security and confidence-building. It may even endanger the lives of people being involved in the peace agreement process (Rwanda, Bosnia). On the other hand, power mediators such as the US, UK or France can also provide greater numbers of peacekeeping personnel, equipment and financial help for new security forces. In that case, greater numbers of personnel and an appropriate time to carry out the mandate are needed. Ideally, a coalition of multiple pure or power mediators should share tasks. This was organized 
very well in the case of Bosnia-Herzegovina in the post-agreement period. The UN, NATO and the EU have shared equal responsibility for post-peacebuilding there.

\subsubsection{Combating Peace Spoilers}

As far as long-term third-party mediation is concerned, peace spoilers are a critical factor occurring in the framework of a peace accord implementation procedure. The notion of peace spoilers and long-lasting third-party involvement is closely related to each other. Due to the absence or weakness of pure or power mediators, peace spoilers may obstruct a peace process by violent activities such as the assassination of VIPs from either side, bomb attacks, kidnapping or hate propaganda.

Peace spoilers versus third-party mediators compete in maintaining and violating peace agreements at the same time. So, the question may be raised whether the failure of the Arusha Peace Agreement was due to the weakness of the UN peace-keeping unit or to the power of peace spoilers in Rwanda. It is pivotal for future research to more closely investigate the correlation between spoilers violating a peace process and fully motivated mediators trying to get the process going. Stedman (1997) describes spoiler problems in peacebuilding period as leaders and parties who perceive the evolving peace threatens their power, values, or priorities, and those who use aggression to sabotage efforts to achieve it (Stedman 1997, 178). He emphasizes his views, giving striking examples from recent history: Rwandan President Juvenal Habyarimana, who declined to enforce the Arusha Accords to resolve his country's internal conflict; Cambodia's Khmer Rouge (KR), which ratified the Paris Peace Agreements but rejected to demobilize its soldiers and started boycotting elections; and the Union for Total Independence of Angola (UNITA), who approved the Bicesse Pacts in 1991 however headed back to fighting after losing the referendum in 1992 (ibid. 180-181).

Spoilers are similarly identified by Call as leaders, parties or excluded groups having lost local or national power in terms of government, security, economy (Call 2012, 38). They might be parties that were originally active in the peace process, but eventually changed their minds and deliberately failed to comply with the peace process conditions. According to Stedman (1997, 179), third-party mediators such as international organizations are "custodians of peace". 
International, regional powers (e.g., the UN, ECOWAS, NATO) proved to be powerful mediators in Sierra Leone, Liberia, Bosnia and Kosovo, as they succeeded in maintaining substantial post-agreement peace there (Karakus 2015a). Thanks to their vigorous engagement and dedication, there have not been any reports on peace-breaking activities in those countries recently, as spoilers are being kept in check.

The strategy, quantity, quality and identity of spoilers are classified by Stedman in terms of spoiler management mechanisms. There are four sections in his "typological theory of spoiler management". The first deals with the typology of potential spoilers and their leverage, i.e., to what extent they can obstruct peace processes. Once the spoiler's negative influence has exceeded the limits to an alarming degree, a prevention strategy is generated against the spoiler to overcome obstacles. Secondly, depending on the level of the spoiler's leverage, diverse compatible action plans can be developed for custodians to "manage spoilers". Thirdly, as there are different strategies to be chosen from, the most compatible one will be applied, counteracting efficiently the spoiler's negative output. Fourthly, it is important to "sensitize policymakers to the complexities and uncertainties of correctly diagnosing the type of spoiler". The final section comprises previously gained experiences of "successful and failed cases of spoiler management". They are to be critically assessed since they might eventually provide valuable information for future cases (Stedman 1997, 179-180). Research gaps in peace-spoiler activities have been identified, as little attention has been paid to micro-level spoiling effects of domestic actors, national communication media, social networks, NGOs and high ranked people. This can be discussed and developed in future research.

I argue that greater numbers of powerful third parties are involved in implementation processes. They will be more able than single external mediators to prevent spoilers and facilitate implementation. Power mediators can be regularly alerted to monitor peace spoilers with their peacekeeping workforce and communication technology on the spot. Spoilers can be prevented by military means when required. On the other hand, pure mediators can forecast a potential peace spoiler and avert it in advance through intelligence and communication tools. Close communication with locals and national level leaders can help to identify them and their possible spoiling strategies. Society can be regularly informed about their violation potential. As spoiling activities largely vary (assassination, hate propaganda through social networks and 
newspapers, mobilization of civilians against the peace-building process), strategic cooperation of multiple mediators would be best to deal with them. Whenever a third party begins to show weakness, the negative effect of the peace spoiler will be intensified.

\subsubsection{Implementation Timetable}

Implementation procedures leading to peace agreements are to be issued to parties concerned according to a detailed timetable (Arnault 2006). The performance of both sides is then to be evaluated. There is a need to find out to what extent the commitments made by the conflicting parties are met following the agreed timetable. Time lags in implementation processes may delay peace agreements and facilitate the advent of peace spoilers. Conflicting parties should strictly adhere to a specific timetable, which is a basic necessity for coordinated action in building up peace agreements. Moreover, the release of prisoners and disarmament of exguerrillas should be coordinated chronologically in peace negotiations, which could have a soothing effect on the opposing parties. This might help to overcome commitment issues and build up mutual trust for the following step of implementation. 19 out of 26 mediated peaceagreement cases comprised timetable provisions between 1989 and 2012, Angola, Bosnia, Burundi, El Salvador, Guatemala, Guinea-Bissau, Indonesia, Ivory Coast, Lebanon, Liberia, Macedonia, Mali, Mozambique, the Philippines, Rwanda, Sierra Leone, Sudan, Timor-Leste (East Timor), and the UK. Agreements also have several deadlines with various clauses (Joshi et al. 2015).

If there were any delay or postponements (Arnault 2006, 4), adequate solutions should be proposed to overcome such problems to avoid any violent recurrence of conflict. Statistical data concerning conflict recurrence have been provided by Gates et al. (2016). They argue that "135 different countries experienced conflict recurrence. 68 were minor conflicts and 24 were wars. The median duration of post-conflict peace spells was seven years." As we can see from the above-mentioned cases, many international peace agreements contained timetable provisions. To avoid any type of delay, the assigned pure or power third-party mechanism can operate impeccably by the designated timetable. 
I argue that multiple third parties (pure or power mediators) can complete these special tasks more efficiently than a single mediator. Multiple mediators can share the responsibilities and work with each party separately to keep the timetable up. In case of a postponement and commitment problem, pure mediators can utilize their facilitation and communication capacity to rapidly identify the reason. It sometimes happens that in post-war countries communication attempts made by single pure mediators fail to convince the conflicting parties. Other methods such as an economic sanction are believed to give impetus to the implementation of road maps. In some post-agreement countries, power mediators are required to apply military leverage on parties to keep the process going. A coalition of power mediators is likely to exert a greater deal of mediation power. If parties fail to adhere to the timetable despite strenuous mediation efforts, the implementation process is likely to fail. Implementation processes are sometimes hampered by financial shortcomings in post-agreement countries due to their weak economy. In that case, multiple pure or power mediators could share financial costs. A single mediator would be unable to do so or be overstrained. 
Chapter IV:

Methodology and Research Design 
This section introduces the research design, single case and comparative analyses, case selection procedures, identification of dependent and independent variables and detailed elements of the thesis project. There are two specific methods of processing the research question. Firstly, the case analysis is conducted in selected cases. This method facilitates "an in-depth, multifaceted investigation, using qualitative research methods, of a single social phenomenon." (Feagin et al. 1991, 2). It enables us to assess the implementation success/performance of mediators (pure and power mediation, single and multiple mediation types) regarding the provisions imposed in the single cases. Secondly, the selected cases are investigated employing "comparative case studies" (Bennett 2004, 29), which ensures an indepth, comparative investigation of the research question. Comparative case analysis is conducted to specify the correlation between the type of third-party mediation (e.g., pure and power mediations) and the level of implementation success of mediated agreements (i.e., high and low scores) over ten years. Gerring $(2004,342)$ emphasizes the case study as "an intensive study of a single unit for the purpose of understanding a larger class of (similar) units. A unit connotes a spatially bounded phenomenon-e.g., a nation-state, revolution, political party, election, or person - observed at a single point in time or over some delimited period of time". Thus, this research focuses on four selected cases separately and comprises a comparison between the limited number of mediated peace agreement cases which have been picked on the base of constant variable and certain scope condition (Mahoney 2007, 128). Consequently, based on the determined scope condition, the "most similar, different outcome system" (MSDO) will be applied (Rihoux and Ragin 2009, 22-23). This enables us to understand why the degree of successful implementation largely differs in the selected cases, although they are similar.

In quantitative analysis, some scholars went far beyond the conflict termination period, explaining variables of security arrangements, the content of agreements, guarantee for thirdparty, power-sharing and state-capacity for sustainable peace and implementation (Walter 2002; Stedman 2002; Hoddie and Hartzell 2003; Arnault 2006; DeRouen et al. 2010; Pospieszna and Schneider 2011). Studies relating to the implementation of peace agreements have mainly focused on the success and failure of peace agreements. The causal mechanism between certain mediation styles, quantity and the successful implementation of peace agreements has not been extensively investigated yet. 
Svenson examines the impact of mediation on the outcome of power-sharing peace arrangements (2007). He argues that "power mediators outperform pure mediators". Peace agreements vary in their content. Power mediators are more likely to achieve a peace agreement based on military power-sharing, whereas pure mediators are able to pass on "conflictresolution provisions" more easily than power mediators (Svenson 2007, 238). As the impact of pure or power mediation on the implementation of peace agreements has been subject to scant research so far, I feel strongly motivated to delve into this field of research, utilizing single case and comparative case analyses in this dissertation. I wish to point out that a comparative case analysis has never been methodologically carried out in that particular field before, nor have the selected cases ever been compared with one another. This does not only mean entering new territory, it also means providing an essential contribution to conflict prevention and sustainable peace in the framework of international mediation.

The success rate regarding the implementation of peace agreements in the four selected countries varies between high and low scores. According to the elimination process of existing peace agreements, the implementation degree is high when it has reached more than $95 \%$ in ten years. If the degree is less than $59 \%$ within ten years, this reveals that there is a serious problem as far as the implementation process is concerned. It also indicates that the peace agreement is likely to be violated. That kind of peace agreement is referred to as vulnerable or less successful. Peace agreement implementations are assessed by the rules and obligations set up by pure or power mediators over ten years. The implementation and outcome of intrastate peace agreements are evaluated in the dataset of the "Peace Accord Matrix" every year. This unique quantitative data bank enables us to see high and low scores and facilitates the comparison of cases depending on variables (Joshi et al. 2015, 554). This type of evaluation is essential since peace agreements comprise objective or normative conditions such as governmental, military, economic and territorial power-sharing provisions to reach an agreement. However, it does not guarantee successful implementation in a post-agreement process over many years because a post-agreement is an open-end process.

As to the above research question, the type pure and power mediator is identified in the context of the four selected cases. Svensson $(2007,230)$ classifies power mediators as "great powers, 
colonial powers, and neighbouring states, whereas mediators who are representatives of international, regional, or non-governmental organizations, individuals, and small and distant states, are classified as pure mediators". According to that codification, the UN in cooperation with COPAZ in El Salvador and the Organization of Islamic Cooperation (OIC) in the Philippines are pure mediators. By contrast, the Republic of Ireland, the UK in Northern Ireland and Syria in Lebanon are classified as power mediators who were actively engaged in peace processes for ten years. In the following, emphasis will be placed on the method of single-case and comparative case analyses applied in this thesis. Other focal topics are case selection procedures, operationalization of dependent and independent variables and detailed elements of the thesis.

\subsection{Most Similar Different Outcome System (MSDO)}

MSDO enables political scientists to examine different outcomes systematically under the same scope conditions, depending on the number of cases and variables (Rihoux and Ragin 2009, 20). This type of methodological procedure applied in this thesis facilitates investigating implemented cases in terms of power-sharing peace arrangements and third-party mediation. The results vary between high and low scores due to the implementation level and are assessed over ten years. This process sheds light on the factors which complicate or encourage the implementation process under the same scope conditions. The identical characteristics for case selection are a) intra-state conflicts b) signed intra-state peace agreements c) third parties involved in implementation d) implementation time is limited to ten years after signing the peace agreement, e) All peace agreement cases based on power-sharing arrangements are ruled by electoral democratic systems. The following figure comprises the major research unit with its identification of dependent and independent variables: 


\section{Power-Sharing Peace Agreements}

\begin{tabular}{c|c|c|c}
\hline $\begin{array}{c}\text { High } \\
\text { degree of } \\
\text { implementation }\end{array}$ & $\begin{array}{c}\text { Low } \\
\text { degree of } \\
\text { implementation }\end{array}$ & $\begin{array}{c}\text { High } \\
\text { degree of } \\
\text { implementation }\end{array}$ & $\begin{array}{c}\text { Low } \\
\text { degree of } \\
\text { implementation }\end{array}$ \\
\hline Case & Case & Case & Case \\
I & II & III & IV \\
\hline
\end{tabular}

In this dissertation, the Peace Accord Matrix has been used to assess implementation processes and the active involvement of third-party mediators. The data provided by this database enable statistical comparison (Joshi et al. 2015). PAM shows 51 different provisions occurring in 34 different peace agreements (e.g., ceasefire, constitutional reform, DDR, dispute resolution committee, ratification mechanism, electoral/political party reform, human rights, prisoner release, verification mechanisms, military reform, transitional power-sharing government, decentralization/federalism, economic and social development, transitional justice mechanism). Based on the four selected cases, they are categorized into five following groups:

1) The implementation of ceasefire arrangement

2) The implementation of institutional-governmental power-sharing

3) The implementation of security power-sharing

4) The implementation of human rights and reconciliation arrangements

5) The implementation of economic power-sharing

Those five categories feature in the four selected cases and are used throughout the entire comparative case analysis. They face different challenges during the implementation process.

\subsection{Case Selection Procedures}

"Most similar case selection proceeds by (1) defining the relevant universe of cases, (2) identifying key variables of interest that should be similar across the target cases, (3) identifying a variable or variables that should vary meaningfully across the target cases, and 
(4) selecting the desired number of cases - often a pair but sometimes more - that have the specified similarities and differences."(Nielsen 2016, 571).

It is important to clarify on what grounds those four mediated internal conflict cases have been selected to form a new research unit. 26 mediated peace agreements out of 34 resolved intrastate conflicts are documented in the Peace Accord Matrix (Joshi et al. 2015), the "Civil Wars Mediation Datasets" (DeRouen et al. 2011) and "the UCDP Peace Agreement Dataset" (Högbladh 2011). The four cases have been selected based on their similarity, i.e., involving third-party mediators. Their similarity is assessed utilizing the same "independent variables" (Seawright and Gerring 2008, 304). External third parties are involved in all four cases. Selection bias has been avoided, as one should refrain from making general statements. Filtering criteria have been used to select the four final cases. The data figuring in the first table have been supplied by the three above-mentioned datasets, covering a period from 1989 to 2012. They comprise all comprehensive peace agreements, mediated or not, between 1989 and 2012.

Table 1: Mediated and Non-Mediated Cases

\begin{tabular}{lcc}
\hline $\begin{array}{l}\text { Countries with peace } \\
\text { agreements } \\
\text { from 1989 to 2012 }\end{array}$ & $\begin{array}{c}\text { Implementation } \\
\text { Degree after } \\
\text { 10 years }\end{array}$ & $\begin{array}{c}\text { Third-party } \\
\text { experience during the } \\
\text { implementation } \\
\text { Yes: 1 No: 0 }\end{array}$ \\
\hline 1. *Angola (4/4/2002) & $88 \%$ & 1 \\
\hline 2. Bangladesh (12/2/1997) & $49 \%$ & 0 \\
\hline 3. Bosnia (11/21/1995) & $93 \%$ & 1 \\
\hline 4. Burundi (8/28/2000) & $78 \%$ & 1 \\
\hline 5. Cambodia (10/23/1991) & $73 \%$ & 1 \\
\hline 6. Congo-Brazzaville (12/29/1999) & $73 \%$ & 0 \\
\hline 7. Croatia (11/12/1995) & $73 \%$ & 1 \\
\hline 8. *Djibouti (5/12/2001) & $52 \%$ & 1 \\
\hline 9. El Salvador (16/01/1992) & $96 \%$ & 1 \\
\hline 10. Guatemala (12/29/1996) & $69 \%$ & 1 \\
\hline 11. Guinea-Bissau (11/1/1998) & $96 \%$ & 1 \\
\hline
\end{tabular}




\begin{tabular}{lll}
\hline 12. India (2/20/1993) & $24 \%$ & 0 \\
\hline 13. Indonesia (8/15/2005) & $87 \%$ & 1 \\
\hline 14. Ivory Coast (3/4/2007) & $83 \%$ & 1 \\
\hline 15. Lebanon (10/22/1989) & $59 \%$ & 1 \\
\hline 16. Liberia (8/18/2003) & $88 \%$ & 1 \\
\hline 17. Macedonia (08/13/2001) & $91 \%$ & 1 \\
\hline 18. Mali (1/6/1991) & $83 \%$ & 1 \\
\hline 19. Mozambique (10/4/1992) & $92 \%$ & 1 \\
\hline 20. Nepal (11/21/2006) & $72 \%$ & 1 \\
\hline 21. Niger (4/15/1995) & $65 \%$ & 1 \\
\hline 22. UK (Northern Ireland) (04/10/98) & $95 \%$ & 1 \\
\hline 23. Papua New Guinea (8/30/2001) & $89 \%$ & 1 \\
\hline 24. Philippines (9/2/1996) & $59 \%$ & 1 \\
\hline 25. Rwanda (8/4/1993) & $74 \%$ & 1 \\
\hline 26. Senegal (12/30/2004) & $33 \%$ & 0 \\
\hline 27. *Sierra Leone (7/7/1999) & $83 \%$ & 1 \\
\hline 28. South Africa (11/17/1993) & $92 \%$ & 1 \\
\hline 29. Sudan (1/9/2005) & $73 \%$ & 1 \\
\hline 30. Tajikistan (6/27/1997) & $94 \%$ & 1 \\
\hline 31. Timor-Leste (5/5/1999) & & 1 \\
\hline & & 1 \\
\hline
\end{tabular}

Grand Total: 31 countries

26 peace agreements

implemented by

means of mediation

*Note: Angola, Djibouti and Sierra Leone had agreements twice and the most recent ones are listed in the table. Source: Data collection from the Peace Accord Matrix (Joshi et al. 2015), the "Civil Wars Mediation" dataset (DeRouen et al. 2011) and "the UCDP Peace Agreement Dataset” (Högbladh 2011).

26 out of 31 peace agreements were mediated according to Table 1. Peace agreements that were successfully mediated show a high degree of implementations (3/4 implementation at least). According to table 1, 3 implementation cases are having scored the highest and 3 having scored the lowest. The 3 highest scores in mediated peace agreements reached 94\% and more. By contrast, the 3 lowest scorers reached less than $60 \%$. In the following table, six countries are listed according to their implementation scores. It is shown that more than $93 \%$ and less than 
$59 \%$ of implementation have been achieved. Those countries experienced different mediation procedures conducted by international and regional organizations, single countries and famous people until a final peace agreement was achieved. After the 26 cases have been classified into two categories (high and low score implementation), the number of cases reduced to 6 cases.

Table 2: Implementation degree of peace agreements, names of short-term mediators before signing agreements.

\begin{tabular}{|c|c|c|c|}
\hline $\begin{array}{l}\text { Mediated } \\
\text { peace } \\
\text { agreement } \\
\text { cases: }\end{array}$ & $\begin{array}{c}\text { Implementation } \\
\text { degree after } \\
10 \text { years }\end{array}$ & $\begin{array}{c}\text { Signing } \\
\text { date of } \\
\text { peace } \\
\text { agreements } \\
\end{array}$ & $\begin{array}{l}\text { Name of third-party mediators } \\
\text { and/or signatories until conflict } \\
\text { termination }\end{array}$ \\
\hline EI Salvador & $96 \%$ & $(16 / 01 / 1992)$ & UN \\
\hline $\begin{array}{l}\text { UK (Northern } \\
\text { Ireland) }\end{array}$ & $95 \%$ & $(04 / 10 / 1998)$ & $\begin{array}{l}\text { US President Bill Clinton, } \\
\text { Ireland, George Mitchell, (IICD) }\end{array}$ \\
\hline Timor-Leste & $94 \%$ & $(5 / 5 / 1999)$ & UN \\
\hline Lebanon & $59 \%$ & $(10 / 22 / 1989)$ & $\begin{array}{c}\text { US, France, Arab League } \\
\text { Morocco, Algeria, Saudi Arabia }\end{array}$ \\
\hline Senegal & $33 \%$ & $(12 / 30 / 2004)$ & AU med. \\
\hline $\begin{array}{l}\text { The } \\
\text { Philippines }\end{array}$ & $59 \%$ & $(9 / 2 / 1996)$ & OIC \\
\hline
\end{tabular}

Source: Data collections from the "Peace Accord Matrix" (Joshi et al. 2015), "the Civil Wars Mediation" dataset (DeRouen et al. 2011) and "the UCDP Peace Agreement Dataset" (Högbladh 2011).

In the following, the cases have been reduced from six to four. This elimination process is based on the two highest (95\%) and two lowest (59\%) scores of implementations and depends on the 
availability and variation of external mediators. Although the implementation of the Senegalese peace agreement reached the lowest degree (only 33\%), Senegal was excluded, as a long-term mediator could not be identified there. Timor-Leste was excluded because its implementation degree was slightly less than El Salvador's and Northern Ireland's (UK).

Those four remaining countries El Salvador, Lebanon, Northern Ireland (UK), the Philippines, all experienced long-term external mediation. Every country that has experienced a civil war or intra-state conflicts, has its own different story of arranging provisions of peace agreements. Although the provisions of the four peace agreements were not $100 \%$ identical in detail, ${ }^{3}$ they were identical on power-sharing and arrangements grounds. The above-mentioned provisions are grouped into similar categories set up by Joshi et al. $(2015,554)$. Their categorization is extended in the following five subjects:

1) Implementation of ceasefire arrangement 2) Implementation of institutional-governmental power-sharing 3) Implementation of security power-sharing 4) Implementation of human rights and reconciliation arrangements 5) Implementation of economic power-sharing. Each category contains different topic-related provisions. For instance, provisions of "demobilization, disarmament, military reform, paramilitary groups, police reform, prisoner release, reintegration" (Lee et. al. 2016, 498), are summarized in Category 3 (security power-sharing). That means, at least one security-related provision is always available in the "implementation of security power-sharing" category. They are constantly applied in systematic comparative case analysis. Another way of grouping provisions for comparative analysis would be to put them in two categories: governmental and territorial power-sharing arrangements. One could object that these categories would be too broad, and details might be lost in comparative analysis. In the following, the five categories set up will be examined to find out if they apply to all four selected cases:

\footnotetext{
${ }^{3}$ See https://peaceaccords.nd.edu/search-pam
} 


\begin{tabular}{l|c|c|c|c|c} 
& $\begin{array}{c}\text { 1) } \\
\text { Implementati } \\
\text { on of } \\
\text { ceasefire } \\
\text { arrangement }\end{array}$ & $\begin{array}{c}\text { 2) } \\
\text { Implementation } \\
\text { of institutional- } \\
\text { governmental } \\
\text { power-sharing }\end{array}$ & $\begin{array}{c}\text { 3) } \\
\text { Implementation } \\
\text { of security } \\
\text { power-sharing }\end{array}$ & $\begin{array}{c}\text { 4) } \\
\text { Implementation } \\
\text { of human rights } \\
\text { and } \\
\text { reconciliation } \\
\text { arrangements }\end{array}$ & $\begin{array}{c}\text { 5) } \\
\text { Implementation } \\
\text { of economic } \\
\text { power-sharing }\end{array}$ \\
\hline El Salvador: & $\checkmark$ & $\checkmark$ & $\checkmark$ & $\checkmark$ & $\checkmark$ \\
\hline Lebanon: & $\checkmark$ & $\checkmark$ & $\checkmark$ & $\checkmark$ & $\checkmark$ \\
\hline $\begin{array}{l}\text { Northern } \\
\text { Ireland (UK): }\end{array}$ & $\checkmark$ & $\checkmark$ & $\checkmark$ & $\checkmark$ & $\checkmark$ \\
\hline $\begin{array}{l}\text { The } \\
\text { Philippines: }\end{array}$ & $\checkmark$ & $\checkmark$ & $\checkmark$ & $\checkmark$ & $\checkmark$ \\
& & & & &
\end{tabular}

Categories are present and equal in all the selected cases. After the four cases have been carefully analysed and the active role of third-party mediators has been fully identified, the quality of third-party mediation (independent variable) will be subject to a more thorough discussion. The four selected cases will be presented in the configuration of the MSDO system design. In order to investigate the research question, the identification of dependent and independent variables facilitates the ability for systematic research. According to the research question of this dissertation, the dependent variable is the implementation success of peace agreements and the independent variable is mediation conducted by single and multiple pure or power third parties.

\subsubsection{Power Mediators and Pure Mediators}

Power mediation and pure mediation types have achieved different results in peace settlements as far as power-sharing agreements are concerned (Svensson 2007). As there is only limited knowledge about the roles of these two types concerning implementation processes, various aspects of those roles will be clarified in this thesis. External mediators acting before or after peace-agreement processes can be either the same or different actors. The following table is to illustrate this and to classify mediator types in the selected four cases: 
Table 3: Pre-findings of mediator types between pure and power in selected cases before and after peace agreements.

\begin{tabular}{l|l|l|l}
$\begin{array}{l}\text { Country name and } \\
\text { implementation } \\
\text { scores with peace } \\
\text { agreements }\end{array}$ & $\begin{array}{l}\text { Name and type of } \\
\text { mediators } \\
\text { in pre-agreement } \\
\text { (Until conflict } \\
\text { termination) }\end{array}$ & $\begin{array}{l}\text { Name and type of } \\
\text { mediators } \\
\text { in post-agreement } \\
\text { (Implementation } \\
\text { process) }\end{array}$ & $\begin{array}{l}\text { Power versus } \\
\text { Pure Mediators }\end{array}$ \\
\hline $\begin{array}{l}\text { El Salvador } \\
(96 \%)\end{array}$ & $\begin{array}{l}\text { Pure Mediator: } \\
\text { UN }\end{array}$ & $\begin{array}{l}\text { Pure Mediators: } \\
\text { UN and COPAZ }\end{array}$ & $\begin{array}{l}\text { Same pure } \\
\text { mediator }\end{array}$ \\
\hline $\begin{array}{l}\text { Lebanon } \\
(59 \%)\end{array}$ & $\begin{array}{l}\text { Power and Pure } \\
\text { mediators: } \\
\text { US, France, Arab } \\
\text { League } \\
\text { Morocco, Algeria, } \\
\text { Saudi Arabia }\end{array}$ & $\begin{array}{l}\text { Power mediator: } \\
\text { Syria }\end{array}$ & $\begin{array}{l}\text { Different } \\
\text { power/pure } \\
\text { mixed } \\
\text { mediators }\end{array}$ \\
\hline $\begin{array}{l}\text { UK (Northern } \\
(96 \%)\end{array}$ & $\begin{array}{l}\text { Power Mediators: } \\
\text { USA (then US } \\
\text { President Bill Clinton), } \\
\text { Ireland, George, } \\
\text { Mitchell, (IICD) }\end{array}$ & $\begin{array}{l}\text { Power Mediators: } \\
\text { (British-Irish } \\
\text { Intergovernmental } \\
\text { Conference) }\end{array}$ & $\begin{array}{l}\text { Different names } \\
\text { of power } \\
\text { mediators }\end{array}$ \\
\hline $\begin{array}{l}\text { The Philippines } \\
(59 \%)\end{array}$ & $\begin{array}{l}\text { Pure Mediator: } \\
\text { Organization of Islamic } \\
\text { Cooperation (OIC) }\end{array}$ & $\begin{array}{l}\text { Pure Mediator: } \\
\text { Organization of Islamic } \\
\text { Cooperation (OIC) }\end{array}$ & $\begin{array}{l}\text { Same pure } \\
\text { mediators }\end{array}$ \\
\hline
\end{tabular}

Source: Data based on Svensson (2007) and the PAM (Joshi et al. 2015).

Although third parties tried to achieve successful peace agreements in the four countries, implementation scores differ widely. In that regard, the number of pure and power mediators in the field might make a difference in terms of implementation effects. 


\subsubsection{Multiparty Mediation and Single Mediation}

Strategic coordination between multiple mediation or single mediation aims at reaching a successful conflict termination or peace agreement. Scant attention has been paid to mediators' impact on implementation processes. As their quantity and strategic coordination in long-term implementation processes are seen as somewhat vague, this will be investigated in this thesis as a research gap. The four selected cases based on the diversity of long-term third-party mediators and the different results they have attained.

Figure 2: Demonstration of single and multiple mediators in the selected cases

Implementation of Mediated Intrastate Peace Agreements

\begin{tabular}{|c|c|c|c|}
\hline $\begin{array}{c}\text { High } \\
\text { degree of } \\
\text { implementation } \\
\text { case }\end{array}$ & $\begin{array}{c}\text { Low } \\
\text { degree of } \\
\text { implementation } \\
\text { case }\end{array}$ & $\begin{array}{c}\text { High } \\
\text { degree of } \\
\text { implementation } \\
\text { case }\end{array}$ & $\begin{array}{c}\text { Low } \\
\text { degree of } \\
\text { implementation } \\
\text { case }\end{array}$ \\
\hline $\begin{array}{l}\text { El Salvador } \\
\quad(96 \%)\end{array}$ & $\begin{array}{c}\text { Lebanon } \\
(59 \%)\end{array}$ & $\begin{array}{c}\text { Northern Ireland } \\
\qquad(95 \%)\end{array}$ & $\begin{array}{c}\text { The Philippines } \\
(59 \%)\end{array}$ \\
\hline $\begin{array}{c}\text { Multiple } \\
\text { Third-party }\end{array}$ & $\begin{array}{c}\text { Single } \\
\text { Third-Party }\end{array}$ & $\begin{array}{l}\text { Multiple } \\
\text { Third-party }\end{array}$ & $\begin{array}{c}\text { Single } \\
\text { Third-Party }\end{array}$ \\
\hline $\begin{array}{l}\text { UN in cooperation } \\
\text { with COPAZ }\end{array}$ & Syria & $\begin{array}{c}\text { British-Irish } \\
\text { Intergovernmental } \\
\text { Conference }\end{array}$ & $\begin{array}{l}\text { Organization of } \\
\text { Islamic Cooperation } \\
\text { (OIC) }\end{array}$ \\
\hline
\end{tabular}

Source: Data collection from the "Peace Accord Matrix" (Joshi et al. 2015) and (Svensson, 2007, 2009).

As shown in the figure, the independent variable (third-party mediation) is present in all four cases but varies in implementation score. The core argument of the thesis greatly influences implementation scores. This leads to the hypothesis that there is a causal relationship between the mediator's quantity and implementation success, which is fully consistent with the research question. As power and pure mediators reached high scores and low scores twice in all four cases (figure 2), the result doesn't show any variation in success. The research field should therefore be extended in terms of strategic coordination between multiple mediations and single mediation types. The increasing number of third parties on the ground can make the process easier through sharing implementation tasks and responsibilities. 
The following hypothesis is put forward by the combination of existing theories of international mediation: If multiple mediators (pure or power) support an implementation process, they are by far more successful than singly acting mediators. The validity of this assumption will be put to the test. The implementation processes in the four cases will be primarily analysed using the method of the single case study. Subsequently, they will be compared with each other according to the abovementioned five categories. The causal pathway will be identified, and the conclusion will be drawn from the empirical analysis.

\subsection{Data Sources and Limitations}

The impact of third parties on implementation processes in the four countries is assessed employing secondary literature, including academic articles, books, national and international newspapers, reports of NGOs and datasets. The major datasets such as "the UCDP Peace Agreement Dataset" (Högbladh 2011) and the "Peace Accords Matrix" (Joshi et al. 2015) comprise implementation data on intrastate peace agreements. "Introducing the Civil Wars Mediation Dataset" is a relevant dataset compiled by DeRouen Jr, Bercovitch and Pospieszna (DeRouen et al. 2011). The type of mediators (pure versus power) is determined utilizing the classification which has been made by Svensson (2007). It enables us to view and analyse statistical information about implementation rates, mediation success depending on different criteria, type of third parties and different levels of mediation outcomes of various cases.

The flow of information differs widely, depending on the case. National and cross-national reports on how the peace agreements had been successfully implemented have proved to be reliable, valuable sources of information. For instance, the Organization of the Islamic Conference (OIC), the Regional Government of the Autonomous Region of Muslim, the Southern Philippines Council for Peace and Development (SPCPD), the Special Zone of Peace and Development (SZOPAD) kept reporting on the memorable peace agreement in the Philippines, at a national level. The Review of the Criminal Justice System in Northern Ireland, the Independent Commission on Policing for Northern Ireland, the Northern Ireland Community Relations Council, the British-Irish Intergovernmental Conference (BIIC) and the 
Independent International Commission on Decommissioning (IICD) continuously reported on the Good Friday Agreement. COPAZ reported extensively on the Chapultepec Agreement in El Salvador. As there were not any reports at the national level in Lebanon and an appropriate academic environment was missing there, the Annual Country Reports on Human Rights Practices run by the U.S. Department of State is used for evaluation on a year-by-year basis.

The Annual Country Reports on Human Rights Practices by the U.S Department of State, the Human Right Watch, Amnesty International and the Helsinki Commission provide a great deal of cross-national reports. Although these organizations do not focus on the entire implementation of peace agreements, they regularly report on essential components of peace agreements such as human rights, democracy, freedom, security, election, violence, press, justice, institutional reforms and ceasefire. National and cross-national reports, specific literature dealing with politics are complementary to each other in all four selected cases. The combination of these sources mutually provides information about the 5 above-mentioned categories for implementation processes. 
Chapter V:

Case Study and Comparative Case Analysis 
The following chapters describe the single case and comparative analyses concerning peace agreement implementations in El-Salvador (Chapultepec Peace Agreement), Lebanon (Ta'if Peace Agreement), Northern Ireland (UK) (Good Friday Agreement) and the Philippines (Mindanao Final Agreement) viewed in the long run. Firstly, the backgrounds of the respective internal armed conflicts and short-term mediations will be presented which led to peace agreements. Secondly, the implementation of the peace-agreement provisions will be individually investigated in each case. The effect of long-term third-party mediation on implementation processes will be closely examined. The provisions analysed in those peace agreements have been clustered in five categories according to the research design. They will be assessed comparatively for over ten years. Provisions are equally clustered in the following five categories:

1) Implementation of ceasefire arrangements

2) Implementation of institutional-governmental power-sharing

3) Implementation of security power-sharing

4) Implementation of human rights and reconciliation arrangements

5) Implementation of economic power-sharing

These clusters are constantly utilized for a systematic comparative case analysis. The pure third parties in El Salvador and the Philippines, the power third parties in Northern Ireland and Lebanon will be compared in the categories concerned. Pure and power mediations have different strengths and skills for conflict termination. The positive attributes of pure mediators are process skills, communication, facilitation, persuasion, arranging political and territorial power-sharing. Different competencies are attributed to power mediators: military and economic (sponsoring) capacities, leverage (coercion), security guarantee, arranging military power-sharing. Those strengths will be tested when the question arises to what extent they influence implementation processes. Success or failure of long-term third-party mediation will be evaluated. Conditions favouring a quick and straightforward implementation process in a post-conflict society will be examined. Finally, the results of the analyses will be critically discussed comparatively based on findings. 


\subsection{Background of the Internal Armed Conflicts and Mediations}

The backgrounds of the respective internal armed conflicts, mediations up to peace agreements are briefly presented in the selected cases:

1- El-Salvador (Chapultepec Peace Agreement)

2- Lebanon (Ta'if Peace Agreement)

3- Northern Ireland (UK) (Good Friday Agreement)

4- Philippines (Mindanao Final Agreement)

\section{El Salvador (1980-1991):}

The Latin American continent has experienced European colonization, numerous violent intrastate and interstate conflicts, civil resistance, a quick succession of governments, many of them being military or pro-military governments. Following the conclusion of the Cold War, peace agreements were signed in countries where armed conflicts had taken place, in ElSalvador (1992), Guatemala (1996) and Colombia (2016).

Following the chronological order of conflicts and human rights violations in Salvadorian history, one would begin with the massacre of the Salvadorian indigenous people in the city of La Matanza, committed by the military regime in 1932 (General Maximiliano Hernandez Martinez). Society in El Salvador was historically divided into two groups: a) 14 affluent, ultraconservative clans of landowners who dominated the government until the peace agreement was signed in 1992. b) workers and peasants (left-oriented). Property rights of indigenous communities were abolished in 1881-1882 by the Salvadorian government and replaced by a privatization policy. The new strategy of the government (1932) consisted of forcing farmers to plant coffee in western El Salvador, but the indigenous communities rebelled against this new policy. Their rebellion endangered their livelihood. They lost their lands, submitting them to the full control of the fourteen landowners (Benítez 2011, 10). The intensive confrontation between the two sides finally resulted in the genocide of the indigenous (Pipils) in 1932, which led to the (establishment of) various rival insurgent and guerrilla organizations established 
between 1960 and 1990. Those included anti-government paramilitary and political organizations (e.g., the Fuerzas Populares de Liberación (FPL), the People's Revolutionary Army (ERP) and the Farabundo Martí National Liberation Front - (FMLN). In contrast, promilitary and nationalist organisations were also established (e.g., Organización Democrática Nacionalista (ORDEN), La Alianza Republicana Nacionalista - (ARENA).

Salvadorians had to face numerous political crises, military coups and assassinations of people in the public eye. Archbishop Oscar Arnulfo Romero was brutally assassinated. He had dedicated his entire life to equality, justice and peace in El Salvador. The 12 years of internal conflict resulted in approximately 70,000 deaths, with neither side achieving victory. The internal political and military conflict continued until the UN was requested to act as a thirdparty to monitor human rights violations in the framework of the San Jose Accords in 1990. Finally, in 1992, the Chapultepec peace agreement was signed in Mexico City (Wood 2003, 275-277; Peetz 2008).

Both conflicting parties had the urge to stop fighting and invited the UN as a third-party to mediate between them. This shows their strong desire for peace. Crocker et al. $(1999,356)$ argue that there seemed to be a military standoff. Neither side was capable of defeating the other. When the fighting ceased, it became clear that the war could not be won by military means, and that its continuation was causing suffering that could no longer be tolerated. The fight solidified the stalemate, which was costly to both parties. When conflicting parties directly invite third parties as mediators, while a conflict is still ongoing, third-party mediation tends to be more successful. The US played a pivotal role, refusing to support the Salvadorian military any longer. Eventually, the US forced the Salvadorian government to sit down at the negotiation table together with the Farabundo Martí National Liberation Front (FMLN) (Studemeister 2001, 7). Call $(2002,388)$ maintains that following a series of diplomatic gestures, besides a collaborative letter signed by James Baker in favour of the UN's mediation in the conflict, thenUS Secretary-General Javier Perez de Cuellar announced in April 1990 that now the UN would operate as the facilitator. On behalf of the Secretary-General, Alvaro de Soto accepted the role of mediator. 
Signing the Chapultepec peace agreement (1992): The Chapultepec peace agreement „signed on January 16, 1992, in Mexico City, culminated twenty months of negotiations and a series of partial settlements between the government of El Salvador and the FMLN" (Studemeister 2001, 7). The agreement aimed at governmental power-sharing, the regulation of ceasefire, reforming the judicial system, reducing and re-establishing - disarmament, demobilisation, reintegration (DDR) - of military and police forces and guerrillas, the transformation of FMLN into a political party, participation in civil political life and the strengthening of human rights (ibid. 7-8). Even though fundamental reform in the country's economic system was a vital FMLN priority after the conflict, only around $10 \%$ of the ultimate arrangements were devoted to social and economic problems (Stedman 2002, 390). This might be interpreted as weakness, as mediators in short-term negotiation processes might apply a great deal of pressure on conflicting parties to establish a solid basis for dialogues to address the root causes of conflicts. Long-term mediators face a difficult task, as in case of failure the implementation of various provisions might be seriously at stake.

Implementation of Provisions (1992-2002):

The implementation of the Chapultepec Peace Agreement will be closely examined, with a strong focus on the third parties' performance monitored by the ONUSAL in its reports from 1992 to 2002. Implementation conditions, challenges, success and failure will be analysed, conclusions will be drawn by referring to the research question. In the case of El Salvador, the United Nations Observer Mission in El Salvador (ONUSAL) acted as a third party, assuming the prime responsibility for the peace-provision implementation mandated by the Security Council, resolution 693 on 20 May 1991. The UN cooperated very well with the national actor COPAZ. Its mediation type is classified as multiple pure types of mediation that provided power-sharing in El Salvador.

\section{Lebanon (1975-1990):}

Root causes of the Civil War in Lebanon between 1975 and 1990 have been identified by scholars differently. They were attributed to the unfair practice of socio-economic privileges granted to political parties (lack of power-sharing), religion facing confessionalism and sectarianism (rivalry between Maronite Christians, Druze, Sunni, and Shi'a), political ideology 
(right-left, pro-and anti-communism), pro-and anti-status quo for the constitution, assassinations of prominent personalities, opposing foreign-policy priorities and goals (Arabization versus westernization), foreign interference (e.g., Syria, Iran, Israel, France, Saudi Arabia) (O'Ballance 1998; Zahar 2005; Wimmen 2016; Hodali 2018; Enders 2017; UCDP 2017b). All in all, one might say that the above-mentioned reasons provoked the conflict altogether. The causes are likewise related to the historical origins of cleavages. Zahar (2005, 231) summarizes the causes and the onset of the conflict as follows: The Lebanese Civil War officially began on April 13, 1975. A primary cause was frustration with the power-sharing formula that favoured Christians. Traditional elites (primarily Maronites) gained the upper hand and access to state resources, whereas socioeconomically disadvantaged communities (mostly Shia) struggled for more power and access to government resources.

During the civil war, Israel, Syria and the Palestinians were involved in the conflict, cooperating with different conflicting sides according to the political preferences in their respective countries. Christians collaborated with Israel, France and the USA, whereas Muslim parties were supported by Muslim countries such as Syria and Iran. Before the Ta'if Accord was signed in 1989, several ceasefires (e.g., 1975, 1976, 1977, 1984, 1985, 1986, 1989) occurred due to the mediation efforts of third parties (e.g., the UN, the US, Syria, Saudi Arabia, Egypt, the Arab League). However, they were repeatedly violated (O'Ballance 1998). The civil war given rise to the killing of approximately 120,000 individuals (UN 2006, 18).

Signing Ta'if Peace Agreement (1989):

The Ta'if Peace Agreement, which mainly regulated the governmental power-sharing between the conflicting parties in Lebanon, was brokered by Saudi Arabia and the Arab League in the Saudi city of Ta'if in 1989 (Zahar 2005, 13) and guaranteed by the Syrian forces (Stedman et al. 2002, 567; O'Ballance 1998, 193). The power-sharing agreement primarily aimed at the cessation of hostilities, stability, security, good governance, institutionalization, ceasefire, conducting parliamentary and general municipal elections, economic recovery, social development and media reform (Stedman et al. 2002, 567; Zahar 2005, 233). 
The implementation of the stipulated provisions within categories will be carefully scrutinized in the context of the third party-performance from 1989 to 1999. In particular, the Annual Country Reports on Human Rights Practices from the U.S Department of State, Human Right Watch and some previous literature provide very detailed information on a year-by-year basis. Conditions, chances, challenges, success and failures will be examined, conclusions will be taken into consideration as to the outcome of the Ta'if Peace Agreement.

Implementation of Provisions (1989-1999):

Although the implementation degree of the Ta'if Peace Agreement was low (59\%), the agreement has not been violated yet (Joshi et al. 2015). In that regard, Syria as a third-party nation took the prime responsibility to achieve post-war security in Lebanon, as stated in the Ta'if agreement. Besides, Syria and Lebanon had signed an agreement of brotherhood on May 22, 1991, which allowed Syria a kind of guardianship in Lebanon in terms of political and economic security, cooperation in terms of cultural and scientific fields "for the benefit of both fraternal countries" (Tucker 2008, 1409). Syria used to have near-total influence over Lebanon's internal and external politics from 1991 until April 26, 2005. Syria became, in large part, the dominant domestic actor in Lebanon at the same time as the significant key entity orchestrating the changeover from conflict to peace throughout that time frame (Salloukh 2005, 18). After the assassination of Lebanese Prime Minister Hariri in 2005, the political climate grew tense. The Cedar revolution took place. Demonstrators vehemently demanded the withdrawal of the Syrian armed forces. They no longer tolerated Syria's interference in Lebanon's domestic affairs, pleading for an independent Lebanon (Knio 2005). Under the pressure of those events, the Syrian security forces finally withdrew from Lebanon on April 27, 2005. This goes to show how quickly the political climate in Lebanon had changed.

The implementation of the stipulated categories will be carefully scrutinized in light of the third party-performance from 1989 to 1999. Conditions, chances, challenges, success and failures will be examined, conclusions will be taken into consideration as to the outcome of the Ta'if Peace Agreement. 


\section{Northern Ireland (UK) (1968-1998):}

The historical origin of Northern Ireland's internal armed conflict goes back hundreds of years when Oliver Cromwell conquered Ireland and Protestant settlers from Northern England and Scotland took possession of Northern Ireland (Darby 1995; McCarney 1996; McCabe 2001, 548). After the partition of Ireland (1921) into the Republic of Ireland (South) and Ulster (British), the Catholics in Ulster remained under British Protestant rule. The Protestants strongly wished Northern Ireland to remain a territorial part of Britain, whereas the Catholic minority envisaged unification with the Republic of Ireland. Consequently, the Irish Catholic minority was systematically discriminated against by the Protestant rulers over the decades. Unlike the Catholic minority, the Northern Irish Protestants enjoyed a high standard of living and full civil rights. One should have a closer look at the period from 1968 to 1998 to understand the social incompatibilities in Northern Ireland. Harsh discontent caused by harassing sectarianism and discrimination led to the first civil rights movement. The Catholics demanded equal rights such as the "removal of discrimination in the allocation of jobs and houses, permanent emergency legislation and electoral abuses" in 1967 (Darby 1995, 18).

The rising civil movement with its stress on disobedience was ruthlessly suppressed by the British armed forces. As tensions increased, the civil rights movement gradually turned into an armed conflict between the Provisional Irish Republican Army (PIRA), the British armed forces and the Protestant paramilitaries (loyalists) (ibid. 1995). Numerous bomb blasts occurred: Bloody Sunday (1972), the Shankill Road bombing (1993), the London Docklands bombing (1996), the bombing in Omagh (1998). A great number of civilians lost their lives or were severely wounded in the bloody armed struggle. "The violence never reached the most common currently agreed threshold of a 'war' - over 1,000 deaths in a year. Nevertheless, its impact on society in Northern Ireland - an enclave with a population of about 1.5 million - was considerable, with over 3,500 killed and up to 50,000 injured over a thirty-year period." (Dorney 2015).

The conflict continued with different intensity until the Good Friday Peace Agreement was signed in 1998. It petered out in 1999. Several secret peace talks had been held (e.g., Sunningdale talks 1973, Sinn Fein leader Gerry Adams and SDLP leader John Hume in 1980). 
Short-term mediation attempts had been carried out by third parties (e.g., Bill Clinton and US senator George Mitchell). Some peace talks resulted in agreements such as the Anglo-Irish agreement in 1985 (BBC - The Troubles 2017; Dorney 2015). However, it was doomed to fail. Dorney (2015) briefly outlines how the Good Friday Peace Agreement was achieved: The IRA announced its truce in 1997, and Sinn Fein was re-admitted to negotiations. The nationalist SDLP, the Irish government, the Ulster Unionist Party, the Alliance Party, the Progressive Unionist Party, and the Ulster Democratic Party (representing loyalist paramilitaries), as well as the Women's Coalition, were all interested. Ian Paisley's Democratic Unionist Party refused to take part as far as Sinn Fein does. The Good Friday Agreement of 1998 has been the outcome of these arrangements.

Signing Good Friday Agreement (1998):

After a long peace talk, the multilateral power-sharing peace agreement was signed by the Catholic (nationalist) and Protestant (unionist) parties of Northern Ireland, the Republic of Ireland and the United Kingdom on 10 April 1998. Referendums were held in Northern Ireland and the Republic of Ireland after the agreement had been signed. Voters were asked whether they would agree to the terms stated in the peace agreement and whether they would allow necessary constitutional changes $\left(18^{\text {th }}\right.$ Amendment of the Constitution of the Republic of Ireland) to facilitate the Good Friday Agreement (GFA). The majority of the voters in all of Ireland - nationalist, republican, loyalist, unionist - supported the new peace settlement and favoured constitutional changes in the Republic of Ireland. General elections were held on 25 June 1998. It was the first time, since 1918, that the two rival groups jointly voted in favour of a proposed peace agreement (Dunn and Nolan-Halley 1998, 1372-1373).

Implementation of Provisions (1998 - 2008):

Although some delay had occurred in the implementation process of the GFA, it has not been violated so far (after two decades). The implementation of the GFA scored very high in 2008, 95\% (Joshi et al. 2015). In appointing the British-Irish Council and the British-Irish Intergovernmental Conference in the GFA, the third-party assumed the prime responsibility as 
a third-party of creating a post-war implementation monitoring system with reviews and reports. Moreover, an independent international commission was established to monitor the decommissioning process concerning all paramilitary arms. The commission was chaired by former US Senator George Mitchell (Debraggio 2010, 33). The post-conflict process in Northern Ireland and the performance of third parties will be discussed with special emphasis upon the implementation of the peace agreement.

\section{Philippines (Mindanao) (1975 - 1996):}

The Philippines had been part of the Spanish Empire until 1898 when the islands were "ceded by Spain to the United States" of America after the Spanish-American War. Philippine independence was proclaimed in 1946 (Republic of the Philippines) (Halili 2004, 22). The Filipinos belong to ethnically diverse groups with different religions. The majority of the Filipinos are members of the Roman Catholic Church (80-85\%), whereas Muslims (Mindanao) account for 5-10\% (Cavendish 2007, 1256; Dong 2016, 314; Abinales and Amoroso 2017, 11; Nolan 1996, 26).

After the proclamation of the Philippine Republic, the government pursued a strong resettlement policy in Mindanao. The landless Catholic Filipinos were encouraged by the government to move from the northern and central islands to Mindanao, which was "rich in natural resources such as oil and natural gas" (UCDP - Philippines 2018). Mindanao was mainly inhabited by native Moro Muslims. Due to the government's systematic migration policy, land re-distribution problems arose which resulted in a social conflict between Muslims and the new settlers (ibid. 2018). The conflict has been commonly interpreted as a sectarian, ethnic-confessional or ideological dispute between settlers and local inhabitants. However, it was also due to the long-lasting, socio-economic injustice committed by Spain, the former colonial power, and the government of the Republic of the Philippines (GRP). The GRP proved unable to remedy the injustice.

The systematic oppression of Muslims led to violent clashes as in the "Jabidah massacre in March 1968" and a great number of battle-related deaths (120,000 in total) (ibid. 2018) The Bangsamoro movement emerged, aiming for an independent Mindanao for Muslims. Rebel 
factions such as "the Moro National Liberation Front (MNLF), the Moro Islamic Liberation Front (MILF), the Abu Sayyaf Group (ASG), and the Bangsamoro Islamic Freedom Movement (BIFM)" fought for equal rights. The violent conflict bears similarities to the confessional conflicts in Northern Ireland (between Protestants and Catholics), in Lebanon between Christians and Muslims.

Short-term mediations between the GRP and rebel groups (MNLF, MILF) were conducted by third parties between 1975 and 1994. Those third parties were the Organization of the Islamic Conference (OIC) and single countries such as Libya (Muammar Gaddafi), Somalia, Senegal, Saudi Arabia, Indonesia and some unidentified Moslem groups. Those mediations culminated in the Tripoli Agreement (1976) and the Mindanao Peace Agreement in 1996 (DeRouen et al. 2011).

Signing the Mindanao Final Agreement (1996):

The Mindanao Agreement was signed by the Moro National Liberation Front (MNLF) and the GRP many years after negotiations had been held in Jakarta (1993-1996). As the Tripoli Agreement (1976) had proved incomplete, it could not be implemented. It was therefore supplemented by the Mindanao Final Agreement in 1996. The Tripoli Agreement served as a base for the Mindanao Final Peace Agreement which could only be achieved through the active participation of the two rebel parties, the MNLF and the GRP, the Islamic Conference of the Ministerial Six and the Secretary-General of the OIC.

The OIC, in particular, undertook the difficult task of monitoring and implementing the process as a third-party providing long-term mediation. The OIC cooperated with the National Council and independent groups such as the Southern Philippines Council for Peace and Development (SPCPD) and a Joint Monitoring Committee which had been established by the GRP and the MNLF (Mindanao Final Agreement 1996). Financial support for the implementation process was provided by the United Nations (multinational donor program GOP-UNMDP) and other countries. 
Implementation of Provisions (1996-2006):

The impact of a third party such as the OIC will be examined (1996-2006). Moreover, importance is ascribed to the Country Reports on the Human Rights Practices in the Philippines (1996-2006) issued by the U.S. Department of State annually. The reports were very detailed and reflected the political conditions of the Philippines in those days, which enables us to understand the underlying causal mechanism affecting the implementation of success or failure of the specific arrangements. In conclusion, the most important findings will be summed up.

\subsection{Single Case Analysis}

\subsubsection{El-Salvador: Implementation of the Chapultepec Peace Agreement}

\section{Ceasefire}

Several problems posed a risk to the successful implementation of the Chapultepec Peace Agreement (De Soto and Del Castillo 1995, 189). In the case of El Salvador, the ceasefire was implemented after signing the peace agreement which was fully acknowledged as a provision in 1992 (Stedman et al. 2002, 389). The ceasefire was successful, as the conflicting parties were seriously committed to proper disarmament, demobilization of paramilitary groups and rebels in a set schedule under the supervision of multiple mediators. One problem arose because of land issues delaying the implementation process. "The provisions of the land issue had not been spelled out with sufficient clarity in the Chapultepec Agreement. Fortunately, with assistance from various quarters and the cooperation of the parties, it proved possible to resolve the land question in October.“(UN 1992, 5).

The lesson to be learnt from this was that incompatibilities had to be solved by third parties in the peace negotiation process to avoid similar obstacles during the implementation process. This goes to show that uncertainties might violate agreements and endow peace spoilers with more strength. The report emphatically praised the successful ceasefire under the supervision of the UN in May 1992, "The government and FLMN are to be commended for their success 
in maintaining the ceasefire, which has not once been broken." (UN 1992:13). In 1993, it was reported that FMLN had failed to decommission all its weapons. This news "nearly dismantled the peace process in May 1993, while internal political differences produced more delays" (Montgomery 1995, 140). Furthermore, it was found out later that the FMLN had secretly delivered weapons to Nicaragua, which again seriously delayed implementation proceedings. Other peace spoilers "death squads" appeared. They committed heinous atrocities, along with the murder of former FMLN rebels, and harassed to carry out more. Admittedly, both sides to the Peace Accord, in collaborative efforts with the ONUSAL and the UN Secretary-General's publicly denounced the death squads' acts and decided to take sensible precautions to restrain them (Boxcar-admin 2019).

The ceasefire provision was successfully completed from 1994 to 2002. A further lesson learnt from the implementation of this ceasefire-provision is that parties should strictly comply with a set schedule. Third parties ought to monitor processes more closely and cooperate with local and national actors. "Coordination is vital at all stages of the process, whether within the UN system or with appropriate regional and other organizations." (Studemeister 2001, 39). This coordination will be explicitly dealt with in Chapter VII, Cessation of the Armed Forces (Boutros-Ghali 1995, 211).

As uncertainty might violate or hamper progress, dispute issues should be resolved in peacetalks and should not be postponed to post-agreement periods. After a time of 10 years, the overall result was assessed as successful. The success of the ceasefire mainly depended on the conflicting parties' commitment to a scheduled plan providing proper disarmament and demobilization of paramilitary groups and rebels at the same time. The close cooperation and communication between the ONUSAL, the office of the UN Secretary-General, COPAZ, the government and other parties at a national level, civil societies on a local level facilitated the successful implementation process and banned peace spoilers. The multiple pure mediators paved the way for implementation, performing tasks involving monitoring, verification and peace spoiling prevention, resolving commitment problems and enforcing dispute resolution. 


\section{Constitutional Reform}

The constitutional reform focused on the armed forces, the electoral system, the judicial system and human rights. Those four sections were essentially implemented in 1992/1993. Apart from the security forces, "the National Civil Police shall be a new force with a new organization, new officers, new education and training mechanisms and a new doctrine." (Boutros-Ghali 1995, 194-198). This doctrine was based on democratic principles, free from political ideologies. Human rights and constitutional civil authorities were fully respected. The rights of civilians engaging in political activities were not to "be impaired by police activities" (ibid. 199). The judicial system based on the National Council of the Judiciary and Office of the National Council for the Defence of Human Rights was reformed (ibid. 205). The electoral system, in particular the political participation of the FMLN, was newly regulated. "The conversion of the FMLN into a political party, and electoral reform as mandated in the accords, have led to unprecedented levels of political pluralism, highly competitive political processes, and free and fair elections, and more generally to vibrant political debates in El Salvador." (Studemeister 2001, 5). Only one obstacle occurred on November 25, 1992: Three weeks after the culmination of a shaky peace process, El Salvador's left-wing guerrillas on Tuesday halted the disarmament of their militia, claiming that the government has refused to make progress on its pledge to grant land to squatters. Guerrilla leader Shafik Handal has said no more insurgents will lay down their arms until the government provides legal assurances that villagers and some former soldiers who have seized farmland will not be evacuated (Wilkinson 1992).

One obstacle was identified during the implementation process on November 25, 1992. The former FMLN warriors stopped demobilization, as the government had failed to implement the farmland issue. The failure to implement one provision also blocked the following implementation process, which had become a common procedure in El Salvador. The problem was finally solved by the ONUSAL. Needless to say, the success depended on the parties sticking to an imposed schedule and strictly abiding by their commitments. The commitment problems were solved by a mediator, the UN (ONUSAL). It closely monitored the process in cooperation with COPAZ. Communication and facilitation between the conflicting parties were regularly provided by the two pure mediators. 


\section{Electoral/Political Party Reform}

Paving the way to the transformation of the FMLN into a political party, a legal basis was established by the legislative assembly which allowed for pluralism. Promoting the political participation of former rebel groups was one of the key factors for sustainable peace and good democracy. This enhanced governmental power-sharing, which is considered by many researchers as an essential element for peacebuilding (Hartzel and Hoddie 2003, 321). "On 23 January 1992, the Legislative Assembly of El Salvador adopted a new law on national reconciliation, granting amnesty for political crimes and offences under ordinary law, with the exception of cases within the purview of the Commission on the Truth or those committed by individuals already convicted in a jury trial." (Boutros-Ghali 1995, 243). This was the FMLN's first step towards political participation. The following problems were caused by the ONUSAL during the implementation process of electoral/political party reform in May 1992, The government delayed legalizing FMLN as a political party (ibid. 245). Moreover, the parties interpreted the stipulations to be implemented from different points of view, thus adding further delay to the implementation process. However, the ONUSAL got the process back on track. The land issue was one of the central points of conflict, which was finally solved by the ONUSAL. The leaders of the two conflicting parties both had personal telephone contact with the Secretary-General, who strongly complained to them about the implementation delay. After their phone conversation, both parties promised to get the implementation back on the right track. They even made creative suggestions on how to solve the problem (ibid. 245-246).

FMLN was successfully transformed into a political party (Unruh and Williams 2013, 321). The election date was scheduled for March 1994, when the FMLN would participate for the first time in its history. The government required monitoring for those elections. In response to this request, the ONUSAL established an electoral assistance division. This was "an electoral component for the purpose of observing and verifying the Salvadorian general elections scheduled for March 1994 until the proclamation of final results by the Supreme Electoral Tribunal of El Salvador." (Boutros-Ghali 1995, 442). However, the registration of voters proved partially inefficient, as more than 74,000 persons who had requested registration were not included on the electoral roll "because their application could not be validated by a birth 
certificate." (ibid. 51). Finally, the overall conduct of the elections was successful and in full compliance with the ONUSAL's monitoring plan (ibid. 531).

Granting amnesty to former FMLN members and establishing a new legal basis for their equal political participation in the upcoming elections were significant implementations. All that supported governmental power-sharing which is generally considered as one of the main factors securing peace. One problem occurred, as the text dealing with the provisions was diversely interpreted by the conflicting parties. That problem could have been avoided if the text had been composed in a way to set out an appropriate strategy in an unequivocal manner. A similar problem regarding postponements reoccurred. However, those problems were skilfully resolved by the mediator Secretary-General, by Mr. Handals (FMLN leader) and El Salvador's President Cristiani. Communication tools with the rival parties and observers were continuously applied on the spot by the Secretary-General of the UN. Multiple mediators monitored and verified the implementation process to make sure that the implementation of power-sharing would be successful.

\section{Civil Administration Reform}

This provision was aimed at achieving civil administration and "institution-building" in conflict zones after the ceasefire had occurred (Stanley and Holiday 1997). In the case of El Salvador, urgent actions were taken to provide services for a post-conflict society. They relate to water, electricity, telecommunication, roads, agriculture, education, health, new setting of the administration of justice, effectiveness of the legislative, functioning of the non-governmental organizations, guaranteeing members of the FMLN full exercise of their civil and political rights (Boutros-Ghali 1995, 218). Government officials such as former court judges and mayors in exile were free to return to the conflict zones. However, the return of those officials was made difficult, as the FMLN and some local communities raised concerns against it. Eager to resolve this issue, the ONUSAL appealed to the local communities to strive for more communication and overcome this problem to achieve lasting peace and reconciliation (ibid. 244). A collaboration agreement was signed by the opposing parties, allowing officials to return to El Salvador (16 September 1992). That agreement had been achieved through joint action by the ONUSAL and the national Supreme Court of Justice (ibid. 278). As a result, the 
implementation of the civil administration reform was successfully accomplished at the end of 1994. According to Document 118, the Secretary-General's report on the activities of the ONUSAL (14 November 1994) stated that the delay of implementations was due to the shortage of financial funds and resources, "lack of organization and expertise - a common phenomenon in developing countries [...]". In that regard, "the presence and assistance of the United Nations" played a vital role (ibid. 589). The security guarantee was finally established by the parties under the supervision of the UN. The provision was successfully fulfilled.

\section{Truth and Reconciliation Mechanism}

Most Salvadorians did not believe in a successful reconciliation process in El Salvador and feared "social violence" after the implementation process of the peace agreement (Cuevas 2002, 39). A provision relating to reconciliation is indispensable in the process of investigating war crimes in post-conflict societies, as it enhances accountability and ensures human rights. "The Commission on the Truth was established in accordance with the Mexico Agreements of 27 April 1991 (S/23130, pp. 5 and 16-18). It was entrusted with the task of investigating serious acts of violence that had occurred since 1980 and whose impact on society was deemed to require an urgent public knowledge of the truth.” (Boutros-Ghali 1995, 433). 22,000 complaints were filed in court after numerous crimes had been successfully investigated by a commission. Crimes had been committed mainly by security forces against civilians, peasants (extrajudicial executions, death squads' assassinations and torture). Judges had been killed by the FMLN between 1980 and 1991 (ibid. 433). The commission identified most of the serious crimes. Recommendations were made as to reforming the constitution. Reconciliation was acknowledged as a core condition to prevent further crimes in the future (ibid. 434). The adhoc commission urgently requested President Christiani to dismiss 102 officers, as well as the Minister and Vice-Minister of Defence, the significant proportion of commanding officers and colonels (Call 2002, 564). Defence Minister Rene Emilio Ponce and Vice-Minister General Juan Orlando Zepeda stepped down, high-ranking military officials were removed from their posts, as the most atrocious crimes had been committed in their terms of office (ibid. 564).

Further challenges occurred, when the truth commission was pleading with civilian victims to report crimes that had been committed during the civil war. Victims were frightened to tell their 
stories, as they did not want to be exposed personally and put their loved ones at risk. Besides, local human right organizations in El Salvador lacked experience in cooperating with the commission by comparison with other international human rights organizations. Moreover, the government was reluctant to provide information about criminal acts in the past. Military officers lied or withheld the truth (Buergenthal 1994, 513-515). "A few days after the publication of the Report, the government of President Cristiani and the national legislature controlled by his party granted an across-the-board amnesty to all individuals charged with serious acts of violence." (ibid. 537). The unexpected decision triggered lively discussions on whether this kind of amnesty had been planned beforehand to obstruct the work of the truth and reconciliation commission.

\footnotetext{
"However, while amnesties after a civil war may be a legitimate way to put an end to the conflict, the manner in which this amnesty was rushed through the Salvadoran legislature in which the FMLN was not represented- with no time or opportunity for a full national debate on the subject, was unseemly at the very least, indicative of a lack of respect for democratic processes, and thus incompatible with the spirit of the Peace Accords." (ibid. 538).
}

The truth and reconciliation processes were also critically viewed by the UN Secretary-General, who was deeply concerned about the development in El Salvador in July 1997. "In sum, a less than positive evaluation of the actions taken in response to the substantive recommendations of the Commission on the Truth is unavoidable". This is a frustrating setback to seize the Commission's rare chance to make significant progress in the fight against impunity and the advancement of an environment of national reconciliation through its function (UN 1997b, 7).

The implementation did not fully meet the expectations harboured by the commission and the victims. Nevertheless, the truth and reconciliation process aiming at establishing accountability has been unique in Salvadorian history (Call 2002, 576). The UN and COPAZ were unable to apply pressure on the government and the FMLN in terms of seeking the truth. In that regard, the UN should have utilized its position of power more effectively to implement the truth and reconciliation mechanism.

\section{Dispute Resolution Committee}

The dispute resolution committee was one of the major factors guaranteeing implementation safety and peacebuilding. The Commission de Consolidation de la Paz (COPAZ), the 
commission aiming at the consolidation of peace, was established to monitor the implementation process. The COPAZ consisted of "two representatives of the government, including a member of the armed forces, two representatives of the FMLN and one representative of each of the parties or coalitions represented in the Legislative Assembly“ (Boutros-Ghali 1995, 20). In the event of any uncertainties and disputes, COPAZ, the ad-hoc commission supported by the UN, took charge of finding solutions, reporting on the peace process and consulting the conflicting parties. As the mandated ad-hoc commission (19921997) had no executive power, its function was highly inefficient (Boutros-Ghali 1995, 160). The government was able to postpone its responsibilities due to COPAZ's failure to make decisions (Call 2002, 570). The establishment of the Dispute Resolution Committee was successful in terms of cooperation and coordination between the government, FMLN, local communities and ONUSAL. Its mandate expired in 1996.

\section{Judiciary Reform}

The establishment of people's confidence in an impartial legal system seems to have been crucial to the long efficacy of the any peace accord. El Salvador has never had this level of confidence in the past. As a result, it's own establishment used to be a required basis of the modern El Salvador (Negroponte 2012, 158). The judicial system was to be newly reformed following the internationally recognized values of universal human rights such as the division of powers. In that regard, the focus was set on the following subsections:

"(a) Reorganization of the Supreme Court of Justice and a new procedure for the election of
Supreme Court judges [...] (b) An annual allocation from the State budget to the judiciary
amounting to no less than 6 per cent of current income. (c) Creation of the post of a National
Council for the Defence of Human Rights, (d) Election of the Attorney-General of the
Republic [...] (b) Judicial Training School. (c) Career judicial service.“ (Boutros-Ghali 1995,
167-168).

Although several reforms had been achieved in the field of judiciary provisions, the result hoped for by many Salvadorians was rather dissatisfactory. In 1992, a delay of implementation was experienced due to the "tightness of the timetable, an integral component of the accords, together with the complexity of the various commitments undertaken by the two sides, led to major delays in completing certain crucial commitments" (ibid. 266). That issue was solved by Under-Secretary-General Marrack Goulding of the ONUSAL. He repeatedly organized consultations with the parties involved. In matters of legal proceedings such as the prolongation 
of pre-trial detention, several delays reoccurred. They were regularly reported by the ONUSAL under specific numbers such as (A/47/968 S/26033) (UN 1993, 36-38). Accordingly, the UN criticized the Salvadorian judiciary for its lack of proper practice: "Public discontent with the administration of justice has been mounting. The weaknesses in this sector are a fundamental impediment to the consolidation of a truly democratic State." (UN 1997b, 18) Besides, several postponements were identified due to the lack of ratifications, of coordination, of capacity for investigation, due to the lacking political will of government officials (Popkin 2010, 86), due to a sluggish, languid criminal justice system in charge of punishing human rights violations (UN 1997b, 4-19). Call (2002, 580) adequately describes the implementation of the judiciary reform occurring in 1998, "the judicial system remained weak, inefficient, antiquated, overly partisan, and subject to corruption." Although the UN criticized the slow implementation processes, it abstained from imposing sanctions against El Salvador. On the contrary, several recommendations were made by the UN to facilitate implementation processes in the near future.

\section{Military Reform}

"Power correlations are relative and civil-military correlations are not exception... diminishing military autonomy is best accomplished by augmenting civilian power" (Juhn 2006, 12). The provision of military reform was integrated into the peace accord as a sub-section within the framework of constitutional reform. The quality, quantity and doctrinal principles of the armed forces were newly established in line with the democratic values, political order, respect for the constitution and the rule of law, human rights and dignity. From now on, the armed forces were to act only on the level of national defence, maintaining internal peace and nothing else. According to the new regulations, a reform was adopted, i.e., an educational system for the armed forces was introduced, free from any political influence. Cleansing was conducted, seeking out security officers who had abused human rights in the past while on duty. All that was done following the criteria of human rights and dignity. Consequently, the number of armed forces was reduced. New reform procedures were established by the National Intelligence Department. The newly created State Intelligence Agency was to be directly coordinated with civil Salvadorian authorities and the President of the Republic (Boutros-Ghali 1995, 194-198). 
Although there were considerable postponements and problems as to the implementation of a new structure in the armed forces (reduction of armed forces, reform of intelligence services between 1992 and 2002), the government was able to fully implement the provision in compliance with the recommendation of the UN and COPAZ. Former security force officers strongly opposed demobilization. They organized protests, occupying government buildings such as the Legislative Assembly and the Supreme Court of Justice. Demonstrators and the newly established security forces clashed violently in the same place where previous demonstrations had taken place (UN 1995a, 13-14). As the newly established government security forces lacked experience in handling such a violent clash, the implementation process was severely hampered. Whenever peace spoilers come into action, they always cause frustration and political deadlock. Another problem occurred, as members of demobilized forces were given career prospects in civilian life. This project, however, required a lot of money. The multiple pure mediators successfully cooperated with the different parties to prevent peace spoilers. On the whole, the provision was finally implemented.

\section{Police Reform}

The Ministry of Defense was in charge of El Salvador's three law enforcements, i.e., "National Guard, Treasury Police, and National Police" (Montgomery 1995, 168). The establishment of new police forces shows many similarities to the obstacles and problems of military reform. "National Civil Police shall be a new force with a new organization, new officers, new education and training mechanisms and a new doctrine." (Boutros-Ghali 1995, 198). The implementation was fully completed in 1997. However, demobilization and the massive dismissal of former security officers posed a severe problem during the implementation process, as Salvadorian police officers had a great deal of resistance power and formed a new paramilitary organization. The reorganization of security forces was a crucial factor in the peace-building process. "The first difficulty was the government's failure in March 1992 to demobilize the Treasury Police and the National Guard.” (Call 2002, 568). Another mistake was, when Oscar Pena Duran, a former military officer was appointed director of the PNC by the government. The "ONUSAL persisted in opposing the appointment as a violation of the peace accords. When opposition to Pena Duran emerged from Salvadoran conservatives and 
from the previously supportive US government, Pena Duran was forced to resign.” (ibid. 570). The government took every opportunity to employ former security officers in the newly established police forces to maintain its former power impact (ibid. 571). It is obvious that the selfish strategy of the government slowed down the implementation process to a large extent. However, the strong pressure exerted by the US and the ONUSAL on the Salvadorian government largely contributed to the successful implementation. The US leverage helped the ONUSAL. In its reports, the ONUSAL kept referring to the financial shortcomings of the Salvadorian police forces, so it is understood that money played a pivotal role to implement the rest of the peace agreement (Boutros-Ghali 1995, 442). The disarmament process of security forces and guerrilla in El Salvador abandoned numerous fighters from both sides jobless and socially inept, causing a rise in public insecurity (Hopmann 1999, 5).

\section{Demobilization and Disarmament}

According to the Chapultepec Peace Accord, demobilization of former combatants of the FMLN meant returning to normal life, ending armed activities, joining the newly established army and police forces. This predominantly facilitated the implementation process. The number of regular armed forces (FAES) was reduced and its structure newly designed. FMLN fighters were ordered to return to designated locations stated in the agreement. The primary aim of demobilization was that all combatants in the country should withdraw from the conflict zones to their barracks and report in detail on the number of weapons they possessed (e.g., arms, ammunition, mines). That process was to be closely monitored by the ONUSAL in cooperation with COPAZ. Once the weapons had been handed in, they were destroyed in a scheduled timeframe (Boutros-Ghali 1995, 210-212). The implementation was slowed down by the government's lethargic implementation efforts. It was supposed to be achieved in a parallel timeframe. The FMLN complained that "it could not comply with its calendar of demobilization unless the Government met the deadlines for the implementation of political agreements, especially those related to land, political participation by FMLN and recruitment into the National Civil Police.” (ibid. 278-279). 
This type of problem has been identified in other provisions as well. The ONUSAL finally succeeded in solving the land issue, jointly assisted by experts and parties. One of the most flagrant violations of the peace agreement occurred when the FMLN's hidden armoury was discovered in Nicaragua. Facing this emergency issue, Boutros-Ghali wrote to the President of the Security Council (1993), complaining about "the maintenance of such clandestine arms deposits, which is considered the most serious violation to date of the commitments assumed under the Peace Accords." (ibid. 458). Thanks to the initiative taken by the ONUSAL, the weapons were destroyed by the FMLN and the Nicaraguan government. The discovery of the FMLN's clandestine arsenal in Nicaragua proved to be the biggest obstacle for the FMLN to be recognized as a legal, political party by the Supreme Electoral Tribunal. The provision was partially implemented after a ten-year process. It was completed in 1995, disarmament was fully implemented in 2000 . Further proceedings were initiated by the government later.

\section{Reintegration}

The reintegration process of ex-combatants is a sophisticated work that requires the technical assistance of third parties. It was supplied by the UN (Del Castillo 1997; Pugh 2009). The political participation of the FMLN was an important step towards a successful reintegration process. Reintegrating the former combatants of the FMLN meant that they could fully exercise their civil, political and institutional rights. The confidence-building measures proved successful to reintegrate former FMLN combatants (Boutros-Ghali 1995, 219-210).

The ONUSAL continuously cooperated with COPAZ, the government and FMLN in the implementation process, which ended in 2000. Problems arose when the government transformed the Treasury Police and National Guards into the Military Police and the Frontier Guards in March 1992. The government's strategy was to keep security power on its side. This was highly contradictory to the spirit of the peace accord. The ONUSAL urgently requested the government to carry out the cleansing process. After the ONUSAL had made it clear that they would not agree to the government's strategy, the government promised to put an end to the Treasury Police and the National Guards (ibid. 240). Due to the pressure exerted by the ONUSAL, the government abolished the Treasury Police and the National Guards in September 1992 (Call 2002, 559). In order to fully implement the integration, external financial aid and 
technical assistance were urgently needed in the entire post-conflict period (Boutros-Ghali 1995, 584). Several postponements occurred in the implementation process. Cooperation and mutual monitoring between multiple mediators facilitated the implementation process of reintegration.

\section{Prisoner Release}

In matters of guaranteeing human rights and political participation to the FLMN, a provision of prisoner release was stipulated by the parties. The target group consisted of persons in jail for political crimes. There was an "exception of cases within the purview of the Commission on the Truth or those committed by individuals already convicted in a jury trial" (Boutros-Ghali 1995, 243). This step was very important, aiming at full political participation (ibid. 209-210). A general amnesty was proclaimed by the legislative assembly with the intention of positively influencing further peace settlement efforts. After six-month research the truth commission was able to identify who had been the perpetrator or victim (Call 2002, 575). The prisoner release process was assisted by the Salvadorian church, local diplomats, members of the International Committee of the Red Cross, Amnesty International and Americas Watch (Boutros-Ghali 1995, 346). Obstacles did not occur in the implementation process of prisoner release. What facilitated the prisoner release process was the continuous help offered by multiple local and international actors for human rights.

\section{Paramilitary Group}

"El Salvador as "escuadrones muertes," or death squads, operated in tandem with eightythousand member right-wing organisation that supported paramilitary activities and served as the hub of the death squads network."(Mazzei 2009, 130). Several paramilitary groups (e.g., death squads) were established during the Civil War (1960-1990). "The report estimated that the military and paramilitary death squads were responsible for 95 percent of all human rights abuses committed between 1980 and 1992, with the FMLN responsible for the remainder." (Call 2002, 574). The paramilitary organizations were guilty of crimes against the civilian population (e.g., assassination, torture, kidnapping, genocide). Those crimes entailed violent fighting between guerrillas and government forces in different places. "The parties recognize 
the principle that any paramilitary force or group must be proscribed in a State governed by the rule of law." (Boutros-Ghali 1995, 197). The organization, structure and activity of private security were newly regulated following the principles of human rights.

Implementation was difficult because the process of recovering military weapons from private individuals was deliberately slowed down by the government. Although a great number of military weapons had been recovered, the process could not be adequately completed because of uncontrolled weapon proliferation in the past (Call 2002, 549). Moreover, various paramilitary groups had joined together beyond the government's control, adopting new names and refusing to dissolve. The failure of disarmament was, to some extent, due to an inadequate reintegration program, lack of funds and lack of career prospects for ex-warriors. "Over two years after the accords were signed, only 6,000 of 18,000 ex-soldiers had received their severance pay." (ibid. 563). The government failed to fully implement the stipulation. ONUSAL and COPAZ were ineffective to exert pressure on the government.

\section{Human Rights}

Respecting and observing human rights are a solid basis for living together in post-conflict societies. Human rights are an integral part of peace accords to prevent conflict recurrence, to create reconciliation and ensure lasting peace. They are enshrined, interalia, in the UN Charter of Fundamental Rights and the European Convention for the Protection of Human Rights and Fundamental Freedom. In the Chapultepec Accord, human rights and the judicial system were dealt with together, as mentioned above. A new office was created, named "the National Council for the Defence of Human Rights." The human rights process was slowed down due to a financial issue, in 1992. This was a common problem that equally occurred in the implementation process of other provisions (Boutros-Ghali 1995, 247). Although core human rights issues were solved, which was a positive development, many problems remained. The right to life and liberty was continuously violated for political motives, physical and psychological abuse of detained or imprisoned persons, abductions, torture, an inefficient judicial system to protect the rights of individuals, lack of investigations (ibid. 247). The lack of judges and court personnel at district courts posed an insoluble problem (ibid. 248, 254, 378). For a long time, the inefficient standard of the Salvadorian judicial system failed to comply 
with international standards. Moreover, FMLN leaders and supreme court members were assassinated by illegal groups (ibid. 46, 373). In the reports issued by the ONUSAL the following facts were considered as serious obstacles on the way to improve human rights practice according to universal standards: “... the high crime indexes, particularly the proven existence of complex organized-crime networks, coupled with the impunity resulting from the inadequate functioning of the justice system, are currently the greatest obstacles to the effective exercise of human rights in El Salvador." (ibid. 574-575). What made the implementation of the human rights provision extremely difficult were financial issues, frequent impunity due to the lack of investigations or court judges, vengeance committed by death squads. The "accountability for past human rights violations" has equally been identified by Call (2002, 563 ) as a major obstacle in the implementation process. Over the years, respect for human rights and fundamental freedoms has been continuously consolidated in El Salvador.

\section{Refugee}

Refugee crises always occur in civil wars. The return of refugees and displaced persons to their homes poses a major challenge for post-war countries. It was expressly stipulated in the Chapultepec Agreement. "It is estimated that about half a million persons were displaced and approximately 45,000 became refugees. Many of the displaced persons have settled in communities, some of them on abandoned lands." (Boutros-Ghali 1995, 242). Although the implementation of the refugee provision was a matter of great interest for displaced Salvadorians, many refugees and displaced persons living in the USA were reluctant to return home. The offers were not accepted as one would expect, on account of economic and security reasons. As only very few legal issues concerning the return of refugees were reported in $\mathrm{El}$ Salvador, the third parties did not have to bother about implementation.

\section{Internally Displaced Persons}

750,000 civilians have been forcibly displaced, as seen by figures (Call 2002, 548). Their return posed a new challenge as to land ownership in conflict zones. It also affected their right to vote or to run for office. The land question has been characterized as one of the major cause of the military confrontation, which has culminated in the loss of many lands and the displacement of 
many local inhabitants. Whereas the landowners' right to stay on their land was guaranteed in the agreement, peasants were evicted by armed forces. Serious diplomatic efforts were pursued by the Under-Secretary-General, ONUSAL, COPAZ, by the government and FMLN to solve this problem. As they proved successful, occupation and eviction were suspended (BoutrosGhali 1995, 242). The idea that landowners, peasants, former FMLN members and fighters should share farmlands, posed a new challenge. "In August 1993, the Government presented a plan to accelerate land transfers to former combatants of FMLN and landholders" (ibid. 555). The Land Transfer Programme (PTT) tackled the issue of sharing lands in disputed areas. The implementation process continued for years, facing all kinds of bureaucratic and technical problems (UN 1997a, 1-3).

\section{Media Reform}

In the Salvadorian post-conflict society, the mass media widely promoted the political participation of FMLN and the importance of reconciliation. They were a strong pillar of the democratic spirit of the Peace Agreement, widely supporting peace restoration, trying to prevent further political conflicts. COPAZ took charge of monitoring the process and made new suggestions. At the same time, ONUSAL verified the implementation process (Boutros-Ghali 1995, 218). FMLN “obtained licenses for two radio stations and one television channel." (ibid. 243). It was found out in 1994 that the ARENA and the Convergencia Democratica had violated Article 18 which regulated the rules of electoral propaganda. ONUSAL cooperated with the Supreme Electoral Tribunal in order to cope with complaints effectively.

\footnotetext{
"Some 300 complaints were presented to ONUSAL during the campaign period, most of them (23 per cent) dealing with arbitrary or illegitimate action by public authorities. The remainder consisted of acts of intimidation (21 per cent), destruction of propaganda materials (18 per cent), aggression ( 9 per cent), murder ( 7 per cent) and miscellaneous complaints (22 per cent)." (ibid. 529).
}

The implementation of the media reform was successfully implemented in 1995 (Joshi et al. 2015). Serious obstacles were not recorded during the implementation process. 


\section{Economics and Social Developments}

The agrarian issue, one of the main causes of the civil war, was a serious problem in the postwar implementation process. It constituted a key factor for economic and social development in the post-conflict period. The government established a "National Reconstruction Plan" for sharing land between former warriors (Del Castillo 2008, 111). Moreover, a "Forum for Economic and Social Development" was created in which the government and "labour and business sectors" worked together to find answers to land issues (Boutros-Ghali 1995, 161). A problem occurred in conflict zones when the present residents of lands were told to remain on their lands and own them. The security forces evicted the peasants from some areas, as they wished to occupy these lands themselves. COPAZ and ONUSAL mediated between peasants and the government, trying to find a solution but eventually failed. Secretary-General Boutros Boutros-Ghali personally intervened on October 13, 1992, urging President Christiani to fulfil his commitments regarding land transfers (ibid. 256). Although the process was hampered by technical, financial and logistical issues, the land was "legally transferred to almost 35,500 beneficiaries", according to a UN report. Implementation in that regard was completed, as Kofi Annan cooperated with the UNDP and donor governments (UN 1998, 2). The provision was fully implemented thanks to Kofi Annan's intensive diplomatic efforts (1997-1998). Although the UN and COPAZ worked closely together, they could not entirely resolve the commitment problem. In the end, Kofi Annan's constant pressure on the Salvadorian government helped to calm down the situation.

\section{Donor Supports}

Donor support of third parties is very important to facilitate the transition process from conflict to lasting peace. This "would permit the financing of peace accord programs" (Eriksson and Arnold 2000, 37). Financial issues as to reconstruction and reconciliation are a common problem in post-conflict societies.

\footnotetext{
“On 1 April 1993, at the Consultative Group Meeting of donors convened in Paris by the World Bank, the Government of El-Salvador asked the international community to fill a $\$ 600$ million gap in the financing required for programmes directly related to the peace accords for the period 1993-1996. Of the $\$ 1.2$ billion needed overall, the Government had already committed over $\$ 300$ million and the international community just under $\$ 300$ million." (Boutros-Ghali 1995, 50).
} 
Donor countries, international and regional institutions (e.g., The World Bank, IMF, InterAmerican Development Bank, the US) took great interest in financing the process with certain preferences, such as primarily "infrastructural and environmental projects" and less "the promotion of democratic institutions, the reintegration of ex-combatants, housing, purchase farmland, agriculture." (ibid. 44-45). Preference issues were resolved without too much delay, with the help of the UN and donor countries. Resolving those problems strongly facilitated further implementations. The need for technical help was also fully met.

\section{Detailed Implementation Timeline}

Implementations continuously faced delays and postponements. A contractual commitment should be measured by the conflicting parties' compliance with the set schedule of implementation. In the Agreement, the schedule was very well detailed, comprising specific steps to be done on specific days. However, details as to certain provisions had not been worked out by third parties (e.g., the specification of conflict zones, land redistribution to peasants, reconstruction and reformation of security forces). Moreover, considerable delays occurred after the discovery of secret FMLN weapons in Nicaragua and after armed forces had forcibly occupied the land of farmers. Those delays occurred in different periods. Problems of timetable and uncertainty were solved, new agreements were reached between the parties thanks to ONUSAL's brilliant mediation skills (Boutros-Ghali 1995, 598).

The implementation process was closely monitored by ONUSAL and COPAZ. Delays and commitment problems hampered the process. Until 1996, numerous obstacles as to time commitment were caused by both parties. In the course of the mediation process, they have gradually removed thanks to the help of pure mediators, the UN (ONUSAL) and COPAZ. They gave advice, technical assistance and financial support. Studemeister (2001, 40) argues that "the international community should be prepared for the fact that institution-building is a slow process; its progress cannot necessarily be tied to a strict timetable." Numerous delays occurred before the conflicting parties approved of the final agreement. 


\section{Natural Resource Management}

The content of this provision was based on the land distribution between peasants and has been dealt with in the provision of economics and social development.

\section{Review of Agreement}

Based on the New York Agreement of September 1991, the "National Commission for the Consolidation of Peace (COPAZ)" was established for supervising implementation processes and giving advice on how they should be conducted efficiently (Tyroler 1991). COPAZ closely worked together with other parties such as ONUSAL and civil societies, in compliance with the Chapultepec Peace Agreement. COPAZ did not have any executive power in parliament. However, it benefitted from certain privileges such as having direct access to the president. The parties were supposed to inform COPAZ regularly about their implementation efforts. As agreed, COPAZ was given the task of preparing draft laws and amendments to accelerate the implementation process which was to be submitted to parliament (Boutros-Ghali 1995, 160). As COPAZ did not have the right to enforce sanctions, the government repeatedly slowed down the implementation process, reluctant to follow the advice offered by COPAZ (Call 2002, 569). COPAZ as a national and internal third-party between ONUSAL, the government, civil societies and FMLN poured oil on troubled water and got the negotiations back on track, whenever a setback occurred. Difficulties mainly occurred in the following topics:

- truth and reconciliation

- disarmament-demobilization-reintegration process

- farmland redistribution

- return of refugees and internally displaced persons

- judicial system for the protection of human rights

- lack of investigations into previously committed crimes against people

- a reorganisation of security forces (e.g., purification and reduction of armed forces).

Although certain provisions had not been fully implemented, the mandate of COPAZ expired 
in January 1996 (Krennerich 2013, 358). All in all, one can say that the role played by COPAZ was highly beneficial to the implementation process. The pressure exerted by ONUSAL and the US, the positive cooperation of the third parties greatly facilitated the implementation of these provisions.

\section{Verification and Monitoring Mechanism}

The implementation process in El Salvador was regularly monitored by ONUSAL until April 30, 1995. The UN observer mission (ONUSAL) in El-Salvador was legally based on "the San Jose, Mexico City and New York Agreements of 26 July 1990, 27 April 1991 and 25 September 1991." (Boutros-Ghali 1995, 218). It was mandated by the Security Council “on 20 May 1991" in connection with resolution S/RES/693(1991) (The UN Security Council 1991, 33). ONUSAL subdivided its responsibilities into "Human Rights Division," a new "Military Division", "Police Division" and an "electoral division" which monitored the elections (Call 2002, 555). After the agreement had come into force, ONUSAL cooperated with COPAZ, the government and the FMLN to verify, guarantee, supervise and support the implementation process.

ONUSAL regularly issued reports about the implementation efforts taken by the parties. Whenever the process was hampered by delays, postponements and commitment problems, ONUSAL pressured the parties into putting the process back on track. After ONUSAL had completed its mission, MINUSAL started to work on a smaller scale, pursuing the same goal in El Salvador on May 1st, 1995. It was financially supported by Denmark, Norway and Sweden (UN 1995b, 1-2). This mission was replaced by ONUV later (May 1st, 1996- December 31st, 1996). "ONUV consisted of only eight staff members plus three civilian police consultants, and its mandate was to follow up the implementation of pending aspects of the peace accords in El Salvador." (Call 2002, 556).

\section{Result}

The UN and COPAZ are classified as pure and multiple mediation types. They both provided security guarantees and power-sharing between former adversaries in post-conflict El Salvador. 
The implementation of provisions was put into practice stepwise under the clear leadership of the UN. The UN (ONUSAL) closely cooperated with groups such as COPAZ, civil societies and parties at national and local levels. COPAZ dealt with them in a prudent, well-organized manner. It seriously took into account the particular conditions that had caused the conflict in El Salvador. Furthermore, it was largely responsible for the design of the Chapultepec Peace Agreement, which proved to be successful, as misunderstandings had been cleared up and conflict recurrence was prevented. Its skilful negotiation style had already been displayed in previous mediation efforts between the Salvadorian government and guerrilla groups. The implementation of certain provisions proved difficult, such as the truth and reconciliation provision, the disarmament demobilization-reintegration provision (DDR), the farmland redistribution, the return of refugees and internally displaced persons, the judicial system for the protection of human rights, the lack of investigations into previously committed crimes against people. Some issues such as farmland, redistribution or disarmament of rebels needed proper technical and scientific assistance from third parties.

Mediators should be technically trained and legally supported. They should have prior knowledge of the core causes of the conflict, which requires short- and long-term mediation experience. However, specific technical knowledge alone is not sufficient in an implementation process. Multiple long-term mediators should have enough financial capacity and security personnel. They should also possess a great deal of leverage power, should be able to communicate and cooperate with others skilfully. They should also know how to provide power-sharing in an implementation process. The UN demonstrated all those qualities when it successfully dealt with COPAZ, FMLN and the Salvadorian government. It set a perfect example of a successful, long-term implementation of a peace agreement.

ONUSAL likewise displayed excellent communication skills, when it was dealing with various commissions and leaders of both parties at local and national levels during the implementation process. It always acted cautiously and regularly warned UN bodies about new obstacles occurring in the implementation process. Kofi Annan, the then UN Secretary-General, repeatedly addressed both sides personally, complaining to them about specific commitment problems and implementation postponements. For that reason, the UN found it necessary to put pressure on both parties, which facilitated the implementation process. As new technical issues 
emerged, expert commissions were created to provide help. Another pivotal factor that facilitated the implementation process was financial support for the promotion of democratic institutions and the reintegration of ex-combatants. Lack of financial support for implementation would have seriously hampered the peace process. The UN acted jointly with the Salvadorian government, the Salvadorian church, local diplomats, members of the International Committee of the Red Cross, Amnesty International and Americas Watch for granting amnesty to former FMLN members. The Salvadorian government established a new legal basis for equal political participation in future elections, which guaranteed the political inclusion of former rebels. The UN firmly supported the practice of governmental powersharing, as it was very much aware that it was the basis for securing peace. As required by the Salvadorian government, the UN established a monitoring system to be applied in the next national elections. New challenges arose, when an FMLN arms cache was discovered in Nicaragua and when the Salvadorian government granted a general amnesty to assassins from both sides (death squads, illegal organisations).

One aspect that has often been neglected is the impact of national and local media on peace implementation processes. They play a significant role in restoring peace and preventing further political conflicts. They can decrease the power of peace spoilers through peace journalism. Their role should be examined more closely in scientific terms.

The Roman Catholic Church in El Salvador also assumed responsibility in the peace-building process. It successfully brought about a prisoners' exchange between the government and guerrillas. Archbishop Romero was assassinated by a rightist paramilitary in 1980, which made the peace-making efforts of the church look weak and vulnerable. However, the Catholic Church (Archbishop Arturo Rivera y Damas) continued to strongly commit itself to peacebuilding activities from 1984 to 1991 (Chavez 1984). Their activities did not result in any ceasefire or peace agreement.

As the UN was the biggest security power in El Salvador, it conducted most negotiations. It also enjoyed a high level of confidence and was generally considered an unbiased and influential third party internationally. It was genuinely determined to resolve the peace problem in El Salvador, which was not always the case in internal armed conflicts. Peace agreements in 
Rwanda, Bosnia and South Sudan failed. Maybe other external third parties such as ODECA (Organication de Estados Centroamericanos), CELAC (The Community of Latin American and the Caribbean States), the US or Cuba would have been able to provide a successful implementation in El Salvador. Although the US has a great deal of military and economic capacity, it would have certainly been rejected as a third-party mediator by FMLN, since the US had supported the Salvadorian government in times of the Cold War (financial support, intelligence and combat equipment). Despite its former generous support, the USA pressured the Salvadorian government into peace talks and forced it to implement the agreement. On the other hand, the Salvadorian government wouldn't have agreed to have Cuba as a third-party mediator on account of its communist ideology. It was obvious that both parties would eventually ask the UN to be their peace mediator. As there were not any other external third parties in the Salvadorian post-agreement process, a proper implementation process would have seemed impossible there. Powerful peace spoilers and commitment problems occurred regularly. The final peace agreement solved many core issues in terms of government policy and security in the post-conflict era. It should be continuously respected by all Salvadorians to preserve lasting peace. After 10 years the implementation score reached 96\% (Joshi et al. 2015).

\subsubsection{Lebanon: Implementation of the Ta'if Peace Agreement}

\section{Power-sharing Transitional Government}

This provision deals with the transition process from war to peace, in which the former conflicting parties were to share the power of a state apparatus such as executive, legislative and judicial power. This provision likewise occurred in the post-war periods of several countries such as Burundi, Somalia, Rwanda (DeRouen et al. 2010, 337; Pospieszna and Schneider 2011, 20). In the case of Lebanon, the legislative assembly, i.e., the chamber of deputies which regulates government policy, was reformed. There were 108 seats in parliament, equally shared by Christians and Muslims, proportionately shared by the denominations of each sect and by the different administrative districts (UN 2014). The provision was fully implemented in 1992 after law 154 had been passed in parliament (Joshi et al. 2015). A change occurred, when the number of parliamentary seats was increased from 108 to 128 . As per the 
new power-sharing transition government, the President must be a Maronite, the Prime Minister must be a Sunni Muslim, and the Speaker of the House of Deputies must be a Shi'a Muslim. Christians and Muslims are divided proportionally among the 128 deputies. In 1992, a general election took place, albeit in an environment of antagonism (CHRRP 1992, 1044).

Lebanon and Syria signed a mutual accord that underlined the strategic cooperation of both countries and in which the single power mediator Syria was to provide security to Lebanon. It allowed Syria to deploy approximately 35,000 troops, plus intelligent services in different parts of Lebanon (ibid. 1044-1045; Rosiny 2015, 491). The implementation of this accord secured Syria's guardianship in Lebanon. The entry of Syrian armed forces into Lebanon meant direct involvement of the Syrian government in Lebanese domestic political affairs. Although there is not sufficient proof that Syria pushed through the successful implementation of a transitional government, it cannot be denied that the strong presence of Syrian military forces in Lebanon guaranteed a successful implementation of governmental power-sharing.

\section{Executive Branch Reform}

This provision aimed to achieve the power and structure of the executive in post-war Lebanon. The rights, duties and obligations of the President of the Republic, the Prime Minister and the Cabinet were explicitly determined. This reform faced serious obstacles after the newly elected Maronite president Rene Moawad (Cristian Maronite) had been assassinated in November 1989. Another Maronite, Elias Hrawi, was elected president by Parliament, an event critically commented on by Krayem (1997):

\footnotetext{
"Members of this sect were to occupy major positions in key ministries, in the army and in the courts. Such positions included the commander-in-chief of the army, the highest judicial position (President of the Court of Cassation), the positions of the Director-General of both internal security and intelligence and that of Governor of the Central Bank."
}

The authority of the central government had not yet been fully established in Lebanon because of internal and external armed militant groups occupying about 30\% of Lebanese territory (CHRRP 1989, 1468). Their power overlapped with the power of the central government at a national level. The Lebanese Army Commander General Michel Awn strongly opposed the agreement with Syria. He considered the presence of the Syrian army in Lebanon as a blatant 
threat to a fully independent Lebanon. This led to a war between Awn's troops and the Syrian army. Awn lost. This enabled the central authority to further expand its executive power (Zahar 2005, 234). This was the first direct Syrian armed confrontation with Lebanese armed groups in Lebanon. If Syria's military intervention in Lebanon (security guarantee and peace spoiler prevention) had not occurred, previously armed groups in Lebanon would have conserved their political and military status quo, which would have seriously hampered the implementation process. So, the power of balance was ensured, and the executive branch provision was fully implemented in 1990.

\section{Legislative Branch Reform}

Along with the establishment of the Chamber of Deputies assuming legislative power, the establishment of a second senate was agreed upon as an additional chamber (Bicameralism). The idea was to grant representatives of religious groups or "spiritual families" a privilege allowing them to use "veto power" in state affairs. However, a new senate could not be established, as sectarianism was considered to be the main reason for the civil war, posing a serious risk to national cohesion (Rosiny 2015, 492). The first national election in 1992 didn't fulfil the required quality standard in terms of security compliance and full participation of all parties. It could not "reflect the full spectrum of the body politic and cast doubt on the people's ability to change their government democratically." (CHRRP 1994). Christian communities in Lebanon mainly boycotted the election because of the hateful presence of the Syrian army in their country and also because "Sunni prime minister Rafiq al-Hariri" (assassinated in 2005) enjoyed a close relationship with Saudi Arabia (Rosiny 2015, 497). The provision was largely implemented despite serious shortcomings (failure to establish a second Senate, Christians boycotting the polls) (Joshi et al. 2015). The implementation process was very much geared to the benefit of Syria, the power mediator. Syria's political influence on Lebanon was not apparent at first glance.

\section{Electoral/Political Party Reform}

The regulation reform of the electoral law and political party system in the Ta'if Accord is expressed as follows: 
"D. Parliamentary Election Law: Parliamentary elections shall be held in accordance with a new law on the basis of provinces and in the light of rules that guarantee common coexistence between the Lebanese, and that ensure the sound and efficient political representation of all the people's factions and generations [...]" (Ta'if Accords 1989).

In order to guarantee the representation of different religious communities, "Law 154 of 1992 raised the number of parliamentary seats to 128 instead of 108, thus adding 29 new seats to the pre-war parliament." (Salloukh 2006, 644). The Lebanese electoral system is dissimilar from other democracies due to its "confessional" political system (specified seat balances in parliament). Despite controversial discussions in Lebanon, structural sectarianism and confessionalism have helped to enhance the country's national unity in the post-war period. The Christians boycotting the 1992 elections because of the presence of foreign troops in their country, clearly manifested a great deal of national pride. Besides, "there were credible reports of the Syrian Government's involvement in the formation of candidacy ticket alliances" (CHRRP 1992, 1049). It could therefore be assumed that after the implementation of the provision, Syria might have misused its presence in Lebanon to influence domestic policy there. It might also be proof of Syria's biased mediation practice and justified interference in Lebanon's internal affairs.

\section{Decentralization/Federalism}

Administrative decentralization as a major element in governmental power-sharing between parties was part of the Ta'if Peace Accord for governorates and municipalities but was not implemented (Karam 2012, 38; Harb and Atallah 2015, 188; Joshi et al. 2015). The main obstacle to achieving decentralization was the general fear of confessional secession at a national level (Harb and Atallah 2015, 192). A further implementation action was not identified until 1999. Only in 1999 did the Syrian government put pressure (leverage and enforcement) in Lebanon to initiate further implementation actions.

\section{Civil Administration Reform}

This provision named "G. Abolition of Political Sectarianism" dealt with sharing public jobs. It brought about a new policy concerning identity documents. The new selection criteria for 
employment were agreed upon in terms of qualification requirements. They deliberately excluded names of confessions in "the judiciary, the military, security, public, and joint institutions, and in the independent agencies." (Ta'if Accords 1989). The names of sects or denominations did not figure on identity cards anymore. Interior Minister Ziad Baroud issued a circular on February 11, 2009, permitting the Lebanese to remove any link to their faith from the Civil Registry (HRW 2009). The Lebanese government tried to get rid of job selection practices based on confession (lower-paid administrative jobs). This proved to be a difficult task at the beginning (CHRRP 1991, 1492).

The final implementation was realized by Prime Minister Hariri between 1993 and 1997. He established the "Office of the Minister of State for Administrative Reform" in 1993 (OMSAR), which performed implementation activities in administrative issues (El-Zein and Sims 2004, 280). Consequently, the amendments stuck at an impasse for two key reasons: 1) the absence of an arbitrator; and 2) the consensus governance mindset (Karam 2012, 37). The arbiter role was to be played by a national reconciliation commission which was to be formed by the former conflicting parties, neutral parties and NGO's. Syria assumed the long-term mediation responsibility to pressure the conflicting parties into reaching mutual understanding. Another problem occurred in Lebanon: "contradictory interpretations of legal texts and the Constitution" (ibid. 37). The same issue was identified in El Salvador, where political parties interpreted provisions differently for their benefit. An important step towards peace occurred one decade later when the names of people's religious beliefs were barred from IDs in 2009 (Human Rights Watch 2009). This was done to combat religious excesses in Lebanon and promote national unity.

\section{Dispute Resolution Committee}

The dispute resolution committee was stipulated under the "B. Courts" regulation. "2. A constitutional council shall be created to interpret the constitution, to observe the constitutionality of the laws, and to settle disputes and contests emanating from presidential and parliamentary elections." (Ta'if Accord 1989). In 1993 (Law No. 250), the independent constitutional council consisting of 10 members (Christians and Muslims), five "by the Parliament and five by the Council of Ministers" was established by the Parliament's 
ratification and "amended by law No. 43" in 2008 (International Foundation for Electoral Systems 2009). The commission was not instructed to monitor the implementation process of the Ta'if Agreement. Their duty was to control the constitutionality of the laws. Nevertheless, the provision was fully implemented without any Syrian mediation (Joshi et al. 2015).

\section{Judiciary Reform}

"[3]. To ensure the judiciary's independence, a certain number of the Higher Judiciary Council shall be elected by the judiciary body." (Ta'if Accords 1989). The partiality of the judiciary was repeatedly criticized in the report on human rights practices. It was claimed that local or national powers such as the militias on a local level, influential politicians or Syrian intelligence officers constantly intervened "to protect their supporters from detention and prosecution" (CRHRP 1989, 1471; CRHRP 1990, 1525; CRHRP 1991, 1488; CRHRP 1992, 1047; CRHRP 1994; CHRRP 1995). Although the implementation took place in 1989 without any noticeable resistance, the lack of impartiality affected the reputation of the judiciary. Moreover, the interference of the Syrian intelligence service in the Lebanese judiciary proved Syria's selfish political intentions. Syrians constantly pressured the Lebanese judiciary into arresting demonstrators against their presence in Lebanon (Assi 2016, 97).

\section{Military and Paramilitary Reforms}

A military reform was intended in the agreement to ensure domestic security in cooperation with internal security agencies and to defend the homeland against external threats (e.g., Israel). Prime Minister Rafiq Hariri and General Emile Lahoud (1989-1989) were unable to reach a compromise on the reconstruction strategy of Lebanon. As Lahoud did not trust Sunni security officers, he controlled the Republican Guards and Hariri the internal security forces (Knudsen and Gade 2017, 26). The implementation of military reform was blocked because of General Aoun's stubborn attitude against "Syrian tutelage, Hezbollah and the Amal Movement" in Lebanon. He argued that the Syrian presence in Lebanon might cause sectarianism and do harm to national unity (Rosiny 2015, 491). He strongly opposed the new legal government and the armed forces, mobilizing his loyal armed forces which consisted mainly of Maronite Christians (CRHRP 1990, 1522). The Lebanese government required security assistance from Syria to 
defeat Aoun. The clash between Aoun's and Syrian troops "resulted in casualties on both sides and among the civilian population" (CRHRP 1990:1527).

General Aoun was defeated by the Syrian army in October 1990 (Picard and Ramsbotham 2012, 71). This military victory (security guarantee and peace spoiler prevention) enabled Syria to take Lebanon under its tutelage. When the Lebanese parliament decided in favour of a general demobilization and the reorganization of all militias to establish a national army, Hezbollah and Palestinian militias were excluded in the demobilization process, as they were defending South Lebanon against Israel (ibid. 24). Although this provision was implemented about essential issues (Joshi et al. 2015), shortcomings were obvious. The Lebanese armed forces could not operate as a single power for a long time. "Syrian military and intelligence units in Lebanon" conducted "their activities independently of the agreement" (CRHRP 1995). Syrian presence in Lebanon also proved beneficial to internal security. However, Hezbollah forces are still acting independently to maintain regional security. In this context, "Syria has violated the sections of the Ta'if Accord calling for a Syrian military redeployment and the reigning in of outlaw militia groups. Presently, Syria has neither effectuated a redeployment nor moved to disband and disarm the remaining militias in Lebanon." (Slomich 1999, 637).

\section{Refugees and Internally Displaced Persons}

Lebanon has been facing an enormous challenge, as lots of its people were internally and externally displaced due to cruel intrastate conflicts. Moreover, it has had to come to grips with the Palestinian refugee question since the outbreak of the first Arab-Israeli war in 1948 (Picard and Ramsbotham 2012, 100). Upwards of 600,000 Lebanese were relocated during the military conflict, and the soon declared motivating them to come back home. Limited resources, and also persisting insecurity among the displaced, stalled the plan (CRHRP 1994). Unfortunately, this provision could not be entirely implemented for the following reasons (Joshi et al. 2015): political incompatibilities, economic weakness and insecurity in the country negatively impacted returning preferences of Lebanese. Palestinian refugees in the country were not granted Lebanese citizenship due to their involvement in internal conflicts in Lebanon. They were considered an economic burden on account of their integration into the social system. As Lebanon was a small country based on multi-ethnic and multi-religious principles, the complete 
naturalization of Palestinian refugees constituted a challenge to the confessional balance in Lebanon (CRHRP 1989, 1474-1975). Although the government was handing out work permits to Palestinian refugees, Palestinians suffered systematic discrimination in "government services as the national social security fund or to be employed by the government. Some encounter difficulties in obtaining employment in the private sector as well." (CRHRP 1993, 1050). After the peace agreement had been signed, the entire Lebanese cabinet opted against Palestinians permanently staying in Lebanon (Talhami 2003, 97). Syria did not deal with refugee and IDP problems.

As in the case of El Salvador, developmental deficit, poverty, lack of perspective caused insecurity, unrest and chaos in the country. Palestinian refugee camps in Lebanon were a serious problem, as they were dominated by Palestinians who administered justice according to their judicial system, showing disrespect for the young state authority which was still weak in the post-agreement period. After the outbreak of the Syrian Civil War in 2011, the refugee population in Lebanon has dramatically increased, as many Syrians had taken refuge in Lebanon.

\section{Education Reform}

Development, reconstruction and reconciliation in the educational system were agreed upon for schools and universities. Primarily, an obligatory elementary school for all children was required. The state was to have control over books at private schools, encouraging "national belonging, fusion, spiritual and cultural openness, and everything that unifies textbooks on the subjects of history and national education" (Ta'if Accords 1989). The spirit of the Ta'if Accords aimed at the abolishment of sectarianism and confessionalism. Nevertheless, it was noted in the Report on Human Rights Practices that private Lebanese schools propagated religious "hatred" and "confessional segregation" (CRHRP 1989, 1773; CRHRP 1992, 1048). Children from lower-income families had to work for money, lacking the opportunity to attend school. Even if poor families could afford sending their children to school, boys would generally get more education than girls who usually remained at home, doing housework (CRHRP 1995). Social inequality was not reduced by the government. The UN was unable to help financially due to a lack of fund (CRHRP 1995). As a result, the provision could not be fully implemented (Joshi 
et al. 2015). The development of the educational system was more positive at Lebanese universities. The government-guaranteed academic freedom for "professors, curricula, or student groups" which wanted to establish campus associations (CRHRP 1994). Syria never forced the Lebanese government to seek improvement in that field and "abolition of political sectarianism" (Fontana 2016, 75).

\section{Media Reform}

The media provision was regulated in the section "G. Information" to "[...] serve the cautious tendencies and the objective of ending the state of war." (Ta'if Accords 1989). As the Lebanese mass media emphatically voiced the specific political attitudes of the conflicting parties in Lebanon, access to printed media of rival parties was deliberately hampered in areas dominated by one major party (CRHRP 1989, 1473). "The 1991 Lebanese-Syrian security agreement contains a provision effectively banning informational activity that could endanger the security of either state." Several newspapers (e.g., Nida' Al-Watan, Al-Safir and Al-Sharq) were temporarily banned since they targeted rival politicians, which was not in the spirit of the provision aiming at abolishing sectarianism (CRHRP 1994). Although some bills were submitted in parliament, this provision could not be implemented as required (Joshi et al. 2015). Syria did not seem to take any serious interest in a proper implementation process, nor did it pressure the conflicting parties into doing so.

\section{Economic and Social Developments}

This provision was to cope with the economic and social development of Lebanon. "E. Creation of a socio-economic council for development: A socio-economic council shall be created to ensure that representatives of the various sectors participate in drafting the state's socioeconomic policy and providing advice and proposals." (Ta'if Accords 1989). The Hariri government seemed to be successful in restoring trust of the public, stabilizing the economic system, and launching a plan to rebuild the economy's facilities (CRHRP 1994). Although Lebanon urgently required a proper reconstruction in terms of economic and social development, the council that was to solve this problem had not been established in parliament yet. However, "while the costs of this external involvement came in the form of human rights 
abuses, stunted democracy and a lack of reconciliation, Syria provided the space for Lebanon to re-forge its national institutions, begin economic recovery" (Mac Ginty 2016, 154). Substantial, external support was lacking during the first 10 years of the implementation period, which could have facilitated the implementation process to a greater extent.

\section{Ratification Mechanism}

As mentioned before, "the Ta' if Agreement ratified by Parliament in November 1989. [...] gives Muslims and Christians an equal number of seats in an expanded 108-seat parliament and transfers some powers from the President to the Prime Minister and the Council of Ministers." (CRHRP 1989, 1475).

\section{Detailed Implementation Timeline}

Although the Ta'if Peace Agreement (1989) did not contain a detailed timeline for specific provisions (as in the Chapultepec Peace Agreement), it stipulated that the Syrian armed forces should assist the Lebanese forces over "two years" after the ratification. However, the withdrawal of the Syrian armed forces occurred 15 years later (2005). In terms of disarmament, the militias were to deliver their weapons to the Lebanese government "within a period of 6 months, beginning with the approval of the national accord charter." (Ta'if Accords 1989). It is obvious that the agreement failed, as it did not maintain the time envisaged in the agreement. It clearly shows the negotiators' inability to implement the agreement in a phased approach. This demonstrates Syria's lack of comprehensive overview and its inefficiency as a third party.

\section{Withdrawal of Troops}

The provision was regulated within section $\mathrm{C}$ "Third, liberating Lebanon from the Israeli occupation" (Ta'if Accords 1989). The provision was intended to maintain full sovereignty over Lebanon's territory and borders which had been internationally recognized. Two countries, Israel and Syria, retained a strong military presence in Lebanon. Israel had approximately 1,000 soldiers in Lebanon, whereas Syria had 30,000 to 35,000 in 1990 (CRHRP 1990, 1522). As mentioned above, the withdrawal of the Syrian army was delayed until 2005. 
The continuous presence of Syrian soldiers in Lebanon caused an internal armed conflict in 1990, between General Aoun and other Lebanese armed forces backed by Syria. The Ta'if Peace Agreement referred to resolution 425 of the UN Security Council which had ordered a full withdrawal of Israeli forces from Southern Lebanon, which finally occurred in 2000 (Picard and Ramsbotham 2012,37). Due to the pressure exerted by the UN Security Council on Israel and Syria, the withdrawal of both armed forces from Lebanon finally took place.

The Ta'if Peace Agreement was not sufficiently detailed and designed. As the verification mechanism proved inefficient (disarmament of the militias, withdrawal of the Syrian armed forces within two years), the implementation process was considerably delayed. Facing the failed implementation of other provisions, the Lebanese parties postponed implementing provisions. During the implementation process, the "powerful, traditional elites (mostly Maronites) were fighting to maintain their privileges, while socio-economically disadvantaged groups (mostly Shi`a) were fighting for more power and access to state resources (Zahar 2005, 231). Although the conflict in Lebanon seemed to be primarily due to confessional disputes, it was also due to a socio-economic reason.

\section{Result}

In the case of Lebanon, Syria as a third-party mediator is characterized as a single power mediator type. It was responsible for internal security and governmental power-sharing for conflicting parties. Syria's power mediation was only partially successful in the peace agreement implementation. It directly interfered in Lebanon's internal affairs due to a bilateral ,agreement of brotherhood”. By interfering in Lebanon's domestic policy, it acted mainly for its benefit. Although it gained support from Muslim parties in the Lebanese Parliament, the Christian Maronites were strongly opposed to Syrian interference in Lebanon. For that reason, a recurrence of internal armed conflicts occurred (Maronites against Syrian troops). If single countries such as Israel, France, Saudi Arabia, Iran or Turkey had acted as mediators in Lebanon, they would certainly not have been able to achieve better mediation results, since the rival parties in Lebanon are strictly divided into religious groups and stubbornly insist on their cultural identity (Muslims versus Christians). The presence of an unbiased power country or an international organization such as the UN with multiple power mediators would have probably 
been more beneficial to the peace process in Lebanon. The UN is generally considered a nondenominational international agent. It would have certainly been welcomed by the conflicting parties in Lebanon, as it is neutral and strives for international peacekeeping.

In terms of strategic coordination, Syria didn't cooperate with the opposition and other international organization such as Amnesty International or Human Rights Watch. It was unable to establish a national-level monitoring committee consisting of members of rival parties. It was unable to deal with the disputes of rival parties efficiently. It could not resolve commitment problems or cope with numerous postponements of implementation processes at a local and national level. Its exclusionary behaviour as a third party reflects a selfish interest in Lebanese policy.

The inclusion of territorial or governmental power-sharing provisions in peace agreements increases the chance for successful implementation in the long run. Although governmental power-sharing was guaranteed in the constitution in terms of several seats and governmental representations, several provisions were neglected and not implemented (Joshi et al. 2015). Excluding Maronite Christians from governmental power-sharing in Parliament would be a big mistake, as this would possibly cause another internal conflict, so their political participation should be fully guaranteed. The Muslim population in Lebanon is steadily increasing and will be much higher than the Christian population in the future. Therefore, a demographic change might require a new constitutional constellation. Another problem is the huge number of Syrian and Palestinian refugees and their integration into Lebanese society.

Although Syria's military intervention prevented peace-agreement violation and kept the implementation process going, the final implementation scores remained low after 10 years. The strong presence of Syrian troops in Lebanon could not prevent the military revolt of Army Commander General Michel Awn, who used his military power to block governmental powersharing in the Constitution to secure Maronite privileges and maintain the status quo. Lebanon's political sectarianism and pluralistic democracy have remained the subject of vigorous political discussion. Future research is to examine to what extent sectarianism should be abolished in Lebanese post-agreement society. 
The fact that there is hardly any detailed official documentation on the agreement implementation achieved by Syrian and Lebanese authorities, makes it difficult to precisely assess Syria's role in Lebanon. In the case of El Salvador, the UN and COPAZ regularly informed the public about the reasons for success and failure in the implementation process. They assumed full responsibility whenever some failure occurred. Moreover, they stayed in close contact with the parties involved. Lebanon experienced a great number of cruel events such as massacres, assassinations and human right crimes. The transitional justice and reconciliation mechanism could have facilitated reconciliation in Lebanese society but failed in many respects. Moreover, there was not any international third committee to monitor a proper way of implementation. Although a great number of provisions were implemented (Joshi et al. 2015), a lack of quality was identified. Syria's inefficient performance as a third party considerably delayed the implementation process in Lebanon and accounts for a series of failed provisions.

\subsubsection{Northern Ireland (UK): Implementation of the Good Friday Peace Agreement}

\section{Ceasefire}

The ceasefire provision was not dealt with in the Good Friday Agreement. Unlike the ceasefire in El Salvador, the ceasefire in Northern Ireland was first declared by the IRA and some rival paramilitaries in 1994, before the signature of the peace agreement (Connolly 2006, 412). The ceasefire decision was taken unilaterally by the IRA. It was the result of secret talks held from 1990 to 1998, by John Hume of the SDLP and Gerry Adams of Sinn Fein (Debraggio 2010, 32; Nolan 2012, 21). The ceasefire deals greatly facilitated negotiations between the governments of the Republic of Ireland, the UK and the warring parties in Northern Ireland. When the British government and the IRA disagreed on the deadline for decommissioning arms, the ceasefire was violated by the IRA in 1996 (Debraggio 2010, 33; Mac Ginty et al. 2007, 6). A lasting ceasefire was closely related to disarmament. It was understood that the peace process should commence by decommissioning IRA weapons. After considerable delays, the decommissioning process was successfully completed in the post-agreement period in 2005 (BBC 2009). 
A further obstacle to the ceasefire implementation occurred, when an IRA splinter group, emerged. It called itself "The Real IRA" and repeatedly broke the agreed ceasefire (heavy bombing in Omagh 1999 and Derry 2011). It targeted business and trade, even killed two soldiers in 2009 (Nolan 2012, 44). This splinter group posed a serious threat to the ceasefire. In 1999, the issue of decommissioning arms reoccurred in the peace process. "The Loyalist Volunteer Force (LVF) warned that there would be a great strain on its ceasefire if the Irish Republican Army (IRA) did not begin decommissioning." (CAIN 1999). Former Prime Minister Tony Blair greatly contributed to resolving the problem of "the decommissioning of paramilitary weapons and the release of paramilitary prisoners" (BBC 2017a). Eight years after the signature of the GFA, the British-Irish Intergovernmental Conference (BIIC) reported that one of the last remaining paramilitary groups, PIRA, had officially declared the termination of armed actions (2006): The PIRA leadership has pioneered a new decision to give up the armed program in favour of a political trajectory. The good news raised hopes for a lasting ceasefire (CAIN 2006). Although there had been various attempts at violating peace talks before and after the signature of the peace agreement, the leaders of the main parties remained patient, fully determined to secure peace and prevent peace spoilers. Intensive dialogues between multiparty commissions such as the British-Irish Intergovernmental Conference, the BritishIrish Council and the Independent International Commission on Decommissioning (IICD) ensured the ceasefire. These groups also closely monitored them. The completion of decommissioning (disarmament) was the last stage of the ceasefire process in Northern Ireland. The final ceasefire implementation mainly succeeded on account of multilateral monitoring, security guarantee, confidence-building, dispute resolution efforts and cooperation between power mediators and other independent teams.

\section{Power-sharing Transitional Government}

The transitional power-sharing government in Northern Ireland proved to be a sensible phase of implementation procedures. In that regard, it should be noted that it was not only composed of the conflicting parties of Northern Ireland but that the UK also shared its governmental power with Northern Ireland. Two months after the signature of the GFA, the first assembly election 
of Northern Ireland was held on 25 June 1998 (CAIN 1998). The seats were allocated according to the D'Hondt method (See Appendix B).

A coalition government was formed. David Trimble (UUP) and Seamus Mallon (SDLP) were nominated "as First and Deputy First Minister Designate at the inaugural meeting of the shadow Assembly on 1 July 1998." (Wilford 2000, 581). Besides, 10 ministerial posts were nominated by the coalition parties. However, the IRA's delay in decommissioning weapons suspended the power-sharing and executive process in 2002. The issue was resolved by the Independent International Commission on Decommissioning (IICD). The inspectors of IICD reported that the IRA continued to cooperate in the decommissioning process. Martti Ahtisaari and Cyril Ramaphosa, who were inspectors, confirmed on 30 May 2001 that the arms depot "remained secure. We observed that the weapons and explosives continued to be safely and adequately stored. We remain confident that they cannot be used without our detection." (IICD 2001). After IICD's positive report, the executive power body continued to work successfully. The issue of the IRA's reluctance to decommission its arms reoccurred in 2002.

The paramilitary Ulster Defense Association (UDA) equally failed to meet its obligations as to disarmament. This caused the suspension of the executive until 2007. From 2002 to 2007, the independent monitoring commissions (IICD), representatives of the Republic of Ireland and the UK tried their best to resolve the issue. They met in Leeds Castle several times to work out a solution. The solution process of power-sharing was also postponed due to national and European elections in the UK. As money was needed for the implementation process, one billion pounds in financial support was provided by the Republic of Ireland and the UK. On 28 July 2005, the IRA declared an "end to armed campaign" (BBC 2009). On 7 March 2007, the Northern Ireland elections took place, after the issue of the IRA's disarmament had been resolved due to the multilateral meetings, inspections of independent monitoring and agreements. The results were as follows: 


\begin{tabular}{|c|c|c|c|c|c|}
\hline \multicolumn{6}{|c|}{ NORTHERN IRELAND: FINAL RESULT } \\
\hline Party & Seats & Seats $+/-$ & Votes* & Votes \% & $+/-\%$ \\
\hline DUP & 36 & +6 & 207,721 & 30.1 & +4.4 \\
\hline SF & 28 & +4 & 180,573 & 26.2 & +2.6 \\
\hline UUP & 18 & -9 & 103,145 & 14.9 & -7.7 \\
\hline SDLP & 16 & -2 & 105,164 & 15.2 & -1.8 \\
\hline $\mathrm{AP}$ & 7 & +1 & 36,139 & 5.2 & +1.6 \\
\hline GP & 1 & +1 & 11,985 & 1.7 & +1.4 \\
\hline PUP & 1 & 0 & 3,822 & 0.6 & -0.6 \\
\hline UKIP & 0 & 0 & 1,229 & 0.2 & +0.2 \\
\hline
\end{tabular}

Source: BBC (2007) Northern Ireland election overview

Sinn Fein and DUP increased the number of their parliamentary seats compared to previous elections in 1998. The power-sharing of the executive was maintained at the same level as in the election of 2007. As governmental power was now being adequately shared in Stormont (Northern Irish Parliament), the provision had been fully implemented (Joshi et al. 2015). The main obstacle to the implementation of the power-sharing provision had been the delayed decommissioning of weapons, as the IRA was reluctant to disarm. There had also been a great deal of mutual distrust severely hampering the ceasefire process.

\section{Constitutional Reform}

The territorial definition of the border in Ireland required an amendment in the Constitution of the Irish Republic. The constitutional reform was implemented by referendum in the Republic of Ireland on 22 May 1998. "The Irish parliament passed the 19th Amendment to the Constitution Bill which would allow for the necessary changes following the Good Friday Agreement." (CAIN 1998). As a result of this reform, the Republic of Ireland no longer makes 
territorial claims to Northern Ireland. It emphasizes the cultural unity of Irish people in different parts of the island.

\section{Inter-Ethnic / State Council}

Although there was dissatisfaction with the establishment of the Civic Forum (e.g., lack of gender balance, members of anti-agreement unionist groups), the Forum started working on 9 October 2000. "The Forum must report back to the Assembly every twelve months." (BBC 2018). Its duties such as the consultation of the government "on social, economic and cultural issues" are stated in detail in the GFA, paragraph 34 (Nolan 2012, 171). It is necessary to solve issues effectively by multi-party committees, forums, councils, groups, conferences. As systematically dealing with issues facilitated the implementation process, the provision was largely implemented. The implementation of this provision shows multi-party power mediators successfully cooperated with other external and internal experts.

\section{Electoral / Political Party Reform}

The parliamentary system of Northern Ireland is entirely different from the electoral system in Lebanon with its confessional segregation and guaranteed number of seats. The Northern Ireland assembly consists of 108 seats and their allocation is based on the D'Hondt System. The proportional representation system is based only on one transferable single vote. The voters were familiar with the electoral system which originated in 1973 and which had been practised before the governmental power-sharing in Northern Ireland (Barnett 2017, 55). Sinn Fein achieved significant electoral gains in the second election, particularly after the GFA and disarmament of the IRA. This shows that, as soon as an armed conflict has been terminated, the political arms of insurgent movements stand a good chance to gain public support. No reciprocity problems were reported for full implementation.

\section{Decentralization / Federalism}

Decentralization was achieved by a properly working parliamentary system based on the D’Hondt System (Unionists and Republican Parties). Although cross-community participation 
in politics was guaranteed in the agreement, the power-sharing process was repeatedly hampered. It was even suspended because of the decommissioning issue between 2002 and 2007. The draft law had been adopted by the House of Commons and the House of Lords at Westminster on 19 Nv, 1998 (Hazell 2000, 2).

\section{Dispute Resolution Commission}

The agreement stated that legislative disputes in Northern Ireland were to be resolved in courts. The British-Irish Intergovernmental Conference was established for that purpose on $17 \mathrm{De}$, 1998. The conference encouraged cooperation between both countries to resolve implementation issues, monitored the governmental development, established institutions, decommissioned arms, engendered reconciliation in Northern Ireland. The conference settled the following issues in bilateral cooperation:

\footnotetext{
"Asylum and immigration, including common travel area issues, European Union and international issues, social security including methods of fraud detection, education, policy on the misuse of drugs: combating organized crime and associated money laundering, fiscal issues [...], rights, policing, criminal justice, normalization of security arrangements and practices, cross-border security co-operation, victims of violence, prison issues, drugs and drug trafficking," (CAIN 2018).
}

The representatives of Northern Ireland were also invited to the regular meetings. The meetings were held regularly from 17 December 1999 to 26 February 2007. The implementation process was reviewed by the commission in reports.

\section{Judiciary Reform}

It was stipulated in the agreement that a review group should be formed to establish a functioning and equitable criminal justice system with an effective legal prosecution for the communities. This group made "294 recommendations" and brought about a great deal of improvement concerning the Northern Ireland Parliament (CSCE 2004, 145). However, the amending proposals failed to reform criminal justice in Northern Ireland at that time. The fact that the "preliminary implementation plan" was drafted as a Criminal Justice Bill (2001) was a step forward. Later, in 2004, the Justice Act received "Royal Assent" (McKernan and McQuade 2004, 124). Although the members of the British-Irish Intergovernmental Conference regularly 
discussed the significance of implementation and emphasized the importance of cooperation regarding criminal justice, only several changes were made in public prosecution (2005) and policing (2006) (CAIN 2006). It took 10 years altogether to complete the implementation process. In the case of Northern Ireland, a truth commission was missing. The creation of a truth commission would have been of great help. It could have helped traumatized victims and facilitated reconciliation between the post-conflict communities. The two power mediators worked well together with the British-Irish Intergovernmental Conference to enable the implementation of judiciary reform.

\section{Police Reform}

It was stated in Annex A that a new police service should be established in Northern Ireland. An Independent Commission on Policing for Northern Ireland was set up with experts and international representatives on policing (Patten 1999). Although the Unionists and Sein Fein initially opposed the implementation of recommendations in the first phase, the recommendations were fully implemented (2002-2007) (Joshi et al. 2015).

The commission found fault with the Royal Ulster Constabulary (RUC), which had been the police force in Northern Ireland from 1922 to 1998. It criticized the inordinate employment of personnel from unionist and nationalist communities. Furthermore, the RUC was seen traditionally as a symbol of "oppression" in the Protestant communities (Patten 1999, 2). By the draft resolution, a 50:50 basis police recruitment from Catholic and Protestant communities was recommended (ibid. 88). The RUC was renamed the Police Service of Northern Ireland on November 4, 2001, and the Police Committee universally acknowledged on a "badge for the new service on December 12" (BBC 2015a). The latest statistics as to the number of staffs in the Police Service of Northern Ireland are as follows:

Table 4: Police service of Northern Ireland

Workforce Composition (Police) Statistics in Northern Ireland 


\begin{tabular}{llc} 
& $\begin{array}{l}\text { Police } \\
\text { Officers }\end{array}$ & $\begin{array}{l}\text { Police } \\
\text { Staff }\end{array}$ \\
\hline \% Perceived Protestant & $\mathbf{6 7 . 1 6}$ & $\mathbf{7 8 . 0 9}$ \\
\% Perceived Roman Catholic & $\mathbf{3 1 . 5 0}$ & $\mathbf{1 9 . 3 5}$ \\
\% Not Determined & 1.34 & 2.56 \\
\% Female & 29.09 & 58.58 \\
$\%$ Male & 70.91 & 41.42 \\
$\%$ Ethnic Minority & 0.52 & 0.63 \\
Total & 6756 & 2383 \\
\hline
\end{tabular}

Source: Police Service of Northern Ireland 2017

The police reform in Northern Ireland has similarities with the police reform in El Salvador regarding its proportional recruitment between rival parties, new structure and policy, form, training, education, development in human rights. International representatives on policing supported the implementation process.

\section{Demobilization}

The demobilization issue focused on the removal of the British security forces from Northern Ireland. The removal of the troops lasted until 2007. The delay of the removal was due to the IRA's delayed decommissioning of arms. According to Archick (2017, 7), the British army concluded its 38-year military campaign in Northern Ireland in July 2007 as part of the peace settlement and strengthened security conditions. While a force of 5,000 British soldiers is stationed in Northern Ireland, they are no longer responsible for security and will be dispatched elsewhere in the part of the world. The PSNI is now in charge of policing in Northern Ireland. The implementation was largely successful in Northern Ireland despite numerous postponements of security questions. 


\section{Disarmament}

Disarmament was a key issue before and after the signature of the Good Friday Agreement. It was stipulated in Art. 7.4 that the implementation procedures should be monitored by the Independent International Commission on Decommissioning (IICD): The Independent Body would then track, evaluate, as well as ascertain advancement upon on decommissioning of illegal weapons, and also provide constant updates between both government agencies (Good Friday Agreement 1998). The first meeting was chaired by former Prime Minister Tony Blair and Bertie Ahern TD on 19 December 1999. The regular meetings lasted from 4 July 1999 to 2011 (IICD 1999-2011). Several problems occurred while the decommissioning of paramilitary organizations was going on (IRA). Due to continuous, multilateral pressure from different independent commissions, political figures and parties, the implementation was successfully completed. The consolidation of governmental power-sharing had also provided an impetus for the implementation process. The BBC (2009) confirmed that the IRA had finalized its decommissioning of arms on 28 July 2005. In the report made by IICD in September 2005, the inspectors stated: Nevertheless, we may document that the weapons used in the recent events include a wide variety of bullets, shotguns, automatic weapons, mortars, rockets, handguns, bombs, destructive materials, and other arms, covering all of the components listed in the security forces' figures.

An approximate estimate of the IRA's quantity of arms was made, based on Security Estimates/Jane's Intelligence Review, which was published by the BBC in (2005): "1,000 rifles, 2 tonnes of Semtex, 20-30 heavy machine guns, 7 Surface-to-air missiles (unused), 7 flame throwers, 1,200 detonators, 11 rocket-propelled grenade launchers, 90 handguns, 100+ grenades". All in all, the implementation process was sped up by continuous, multilateral pressure from mediators, different independent commissions, international commissions, political parties and politicians.

\section{Reintegration}

A program facilitating the return of paramilitaries from prisons into society was established within the financial limits of the reintegration provision. It provided employment opportunities 
by using re-training and educational facilities. The voluntary bodies administered reintegration procedures in Northern Ireland, which were financed by the European Union (Williamson and Halfpenny 2000). The provision was fully implemented in 1998 (Joshi et al. 2015). The reintegration process in El Salvador was more difficult than the one in Northern Ireland due to the high number of paramilitaries and the lack of financial resources there.

\section{Prisoner Release}

Amnesty for prisoners was one of the most notable features of the ceasefire and the Peace Agreement. Paramilitaries were released as long as they remained fully committed to the ceasefire agreement. The paramilitary organisations were "The Continuity Irish Republican Army, the Loyalist Volunteer Force, the Orange Volunteers", the "Real" Irish Republican Army, the Red Hand Commando, the Red Hand Defenders, the Ulster Volunteer Force" (The Sentence Review Commissioners 2008). Sinn Fein and the British Government did not agree on the timing of the prisoners' release (time-varying between 1 and 3 years). Due to the mediation of then US President Bill Clinton and Sinn Fein leader Gerry Adams, time was shortened to 1 year (Debraggio 2010, 37).

The Sentence Review Commissioners was appointed by the British Parliament in July 1998 by the GFA (The Sentence Review Commissioners 2008). It was to review and regulate the prisoner release. Up to 500 loyalist and republican inmates convicted until the deal could be freed by July 28, 2000 (BBC 2015b). The agreement was fully implemented thanks to the Sentence Review Commissioners. Although former US President Bill Clinton was a power mediator, he was in full command of communication and facilitation strategies which are usually attributed to pure mediators. He and Sinn Fein leader Gerry Adams made strenuous efforts to achieve the implementation of this provision.

\section{Paramilitary Groups}

Under the regulation for security issues in the Good Friday Agreement, it was agreed that the Secretary of State will interact including the Irish Government and political factions on progressing premise development and the response towards ongoing paramilitary violence, 
whenever relevant (Walsh 2017, 221). Different independent commissions were established to monitor paramilitary issues concerning the ceasefire, the decommissioning of arms, prisoner release, demobilization, re-integration. Several key measures were taken by paramilitaries to secure the ceasefire and peace agreement. The provision was largely implemented within 10 years (Joshi et al. 2015).

\title{
Human Rights
}

In the Good Friday Agreement, the rival parties unanimously declared to respect human rights. They are equivalent to those adopted by the European Convention on Human Rights (ECHR). The Northern Ireland Human Rights Commission was established. Its task consisted of dealing efficiently with human right issues by monitoring human rights activities. "The inaugural meeting" of the commission was held on 1 March 1999 (NIHRC 1999). It emphasized the following aspects:

\begin{abstract}
"Advising the Westminster government, the Northern Ireland Executive and Assembly, and key agencies on legislation and compliance with human rights frameworks, Our work to promote awareness of human rights through education, training and research, Our international treaty monitoring work, Our legal advice work including taking strategic legal cases, Our engagement with other national human rights institutions in the UK, Our work as part of the Joint Committee with the Irish Human Rights and Equality Commission (IHREC)" (NIHRC 2020).
\end{abstract}

The implementation was successful under the supervision of the British-Irish Intergovernmental Conference. Multiple challenges had to be overcome (e.g., deep-rooted sectarian hatred, mutual discrimination, harassment, violence). There are still socially explosive areas in Northern Ireland (i.e., traditional parades organized by Protestant Unionists and Irish Nationalists, "peace walls" in working-class urban areas separating Catholics and Protestants).

\section{Right to Self-Determination}

The right to self-determination was achieved by a referendum in Northern Ireland in 1998. The question was: "Do you support the Agreement reached the multi-party talks on Northern Ireland and set out in Command Paper 3883?". The result was: "Yes 676,966 (71.1\%), No 274,879 (28.9\%) "(Riley 2000). Accordingly, the right to self-determination was guaranteed and thus implemented under the supervision of multiple conciliators. Although Northern Ireland remains 
part of the United Kingdom, the North Ireland voters can decide at any time if they wt sovereignty united Ireland in the future (McCabe 2001, 551). By comparison, the Spanish constitution recognizes the autonomies in Spain; however, it prohibits an independence referendum for its autonomies. We experienced the Independence Referendum in Catalonia which was rejected by the constitutional court of Spain in 2017. In the case of Colombia, the peace agreement was rejected by a narrow majority in the referendum of 2016. The result was: No: 50.22\% and Yes: 49.78\% (BBC 2016; El Tiempo 2016).

\section{Citizenship Reform}

In the wake of constitutional changes, the agreement provided the citizens of Northern Ireland with a referendum of choice between having Irish, British or both citizenships (Debraggio 2010, 46). The amendment concerning citizenship in the Constitution of the Republic of Ireland was changed on 24 June, 204 (Ward 2010, 46). A public referendum in Ireland supported the change with the following results. "The total number of votes recorded in favour of the proposal was $1,427,520$ and the total number recorded against the proposal was 375,695." (Gov.ie 2016). The implementation was successfully completed.

\section{Women's Rights}

Women's rights constitute an important step and quality test for equality. Women are eager to participate in policymaking processes, fight for fair participation in the public sector. As far as their political participation in Northern Ireland is concerned, the Northern Ireland Assembly in 2011 had "the lowest proportion of female representation of any of the four parliaments in the UK. The Republic of Ireland is lower still (15\%), and considerably lower than the worldwide average, which the Inter-Parliamentary Union puts at 20\%.” (Nolan 2012, 166) This clearly shows a lack of female equality in Northern Ireland. The gender issue remained an unresolved problem at that time. 


\section{Minority rights (Education Reform, Official Languages and Symbols)}

In the agreement, the stipulation for education is closely related to the language issue. As the UK is a contracting party in the European Charter for Regional or Minority Languages (ECRML), changes were made in North Ireland education (1998). The UK fulfilled its responsibilities in matters of education and language. The North/South Ministerial (Irish) Council was established on 13 December 1999 to implement language procedures. The most important cooperation area was agreed upon in terms of education (North-South Ministerial Council 1999). The implementation was successful. There had been no obstacles. Although the language reforms had proved successful in promoting cultural diversity, sectarianism between Protestants and Catholics could not be prevented. "While $6.5 \%$ of children now attend integrated schools, this means the other $93.5 \%$ are separated into Catholic and Protestant schools" (Nolan 2012, 10). This means there is a serious lack of integration concerning Protestants and Catholics. The same problem is also identified in Lebanon where children attend schools according to their religious faith. Several regulations were made in the Good Friday Agreement as to flags, symbols and emblems which were to inspire mutual respect and enhance integration into the post-conflict society rather than cause further separation. Important changes as to flying and removing Union Flags in Northern Irish government buildings on specific days were brought about by Parliament (Legislation.gov.uk 2000). Research on Northern Irish flags and emblems in different locations and different years showed that the frequency of flying a flag had been reduced "from 161 in 2006 to 73 in 2009" (Nolan and Bryan 2016, 30). The flag issue, however, could not be fully solved between Nationalist and Unionists in certain districts. In that regard, no action was identified by the mediators.

\section{Reparations}

The agreement dealt with the reparation issue which was regulated under "Strand Three: Reconciliation and Victims of Violence". Reparation procedures constituted good arrangements for victims in terms of restorative transitional justice, as they promoted community-based reconciliation in Northern Ireland. In 2006, "The Commission for Victims and Survivors for Northern Ireland" was established "to promote the interests of victims and survivors." (Legislation.gov.uk 2006). According to an investigation conducted in 2016, the 
number of troubles related deaths had risen to "3,649" (Potter and Campbell 2014, 16). The Peace III Program (2007-2013) allocated nearly 37 million pounds in support to organizations that offer care to survivors of domestic violence (ibid. 2). However, reparation does not only refer to financial or material recovery. In the case of Northern Ireland, no truth commission would help traumatized victims, prevent future conflicts or facilitate reconciliation between post-conflict communities. In that regard, no action was identified by the mediators.

\section{Economic and Social Development}

The Good Friday Agreement regulated the economic and social development of the divided society in urban, rural and border areas, addressing issues such as gender equality, transportation and infrastructure, employment, security etc. A commission was established to implement necessary changes, in particular as to discrimination and equal chances in employment. The commission was "providing protection against discrimination on the grounds of age, disability, race, religion and political opinion, sex and sexual orientation" (Obe 1998). The commission regularly monitored and reported on current problems and various solution processes. Finally, the provision was fully implemented (Joshi et al. 2015).

\section{Ratification Mechanism}

The Good Friday Agreement was ratified by two concurrent referendums in the Republic of Ireland and Northern Ireland on 22 May 1998. By the same token, it was ratified by the House of Commons, the House of Lords and the royal on 19 Nov 1998 (Hazell 2000, 2). The implementation of provisions was regularly reviewed and subsequently ratified by the NorthSouth Ministerial Council, the British-Irish Council, and the British-Irish Intergovernmental Conference. Those councils closely cooperated with further established councils such as the Independent International Commission on Decommissioning (IICD) or Equality Commission, in matters of specific stipulations. Full implementation was identified employing multilateral efforts of power mediators. 


\section{Detailed Timeline}

The most important time schedules in the peace agreement process were the ratifications in the Republic of Ireland, Northern Ireland and the British Parliament, which were mostly implemented on schedule. In contrast, the decommissioning process of arms was deliberately delayed by the IRA and other paramilitary groups. Although delays in the implementation of some provisions had occurred, the provisions were all implemented according to the set schedule (Joshi et al. 2015).

\section{Independence Referendum}

In the course of constitutional reforms, people's freedom of choice was guaranteed in the Good Friday Agreement 1998. It was concluded that the incoming government should respect the validity of any course of action a majority of the citizens of Northern Ireland make about their position, either they chose to remain in the United Kingdom or endorse an independent united Ireland (Gov.uk 1998). That means voters are free to decide on Northern Ireland's future by referendum. Full independence from the United Kingdom or the Republic of Ireland has never been a serious issue, as self-determination has been guaranteed to the people of Northern Ireland. Brexit will affect Northern Ireland's economic, social and foreign affairs with the EU and the UK in the long run. It might also influence the integration process of Unionists and Republicans. As the Republic of Ireland is an EU member, there might be border restrictions again, which might lead to new tension.

\section{Review, Verification and Monitoring Mechanisms of Agreement}

The implementation of the Agreement with its specific provisions was regularly reviewed, verified, sponsored and monitored by power mediators, British, Irish and North Irish officials, assisted by several national, international and independent commissions and mixed councils. Commitment problems and spoiler problems were resolved, confidence-building was improved. Reports were issued to the parties, instructing them how to reform and implement missing implementations. 


\section{Result}

In the case of Northern Ireland, the most important third parties assisting and monitoring the implementation process of the Friday Agreement were the British-Irish Intergovernmental Conference, the Independent International Commission on Decommissioning and the Independent Commission on Policing in Northern Ireland. They were established by external third parties, the UK and the Republic of Ireland (multiple power mediators), as those two countries were considered to be guarantors of a long-term implementation process. Under their leadership, further independent commissions guaranteed security, disarmament and established governmental power-sharing. Due to the enormous efforts of those mediators, successful implementation was achieved. Their success mainly derived from the constant, fruitful dialogues with the rival parties in Northern Ireland and the creation of independent international and national commissions. They resolutely aspired for lasting peace and seriously committed themselves to the prevention of recurrence conflicts. They strove for social integration of all citizens in Northern Ireland and organized financial support for the peace process.

\subsubsection{The Philippines: Implementation of the Mindanao Final Agreement}

\section{Ceasefire}

Several ceasefire arrangements were identified before and after the signature of the peace agreement between the Government of the Republic Philippines (GRP) and the MNLF. Some were long-lasting but not sustainable. In 1975, „Marcos called for a ceasefire and opened the door to negotiations. "More negotiations followed in 1993 and in 1997 (GRP-MILF General Cessation of Hostilities Agreement, Cagayan de Oro City, Philippines - 18 July). A committee for the monitoring of ceasefire was agreed upon, regarding resolution No.1 (Stankovitch 1999, 36, 88-89; Bell and Utley 2015, 4).

The Mindanao Final Agreement did not specify any particular ceasefire provisions, as several ceasefire agreements had already been achieved previously which had paved the way for peace 
talks and the Final Agreement. The OIC, a joint committee of the MNLF and the government were appointed to monitor and implement the ceasefire by the Tripoli Agreement (1976). However, one of the main conflicting parties, the Moro Islamic Liberation Front (MILF) was reluctant to comply with the Mindanao Final Agreement, which might have severely hampered the ceasefire. Fortunately, MILF and the government signed the "Agreement for General Cessation of Hostilities" on 18 July 1997 (Stankovitch 1999, 89) and likewise the new Tripoli Peace Agreement in 2001, which was crucial to the success of the implementation of the ceasefire provision (Amer and Zou 2011, 69).

According to the Country Reports on Human Rights Practices in the Philippines, several violent clashes occurred in Mindanao. When the Armed Forces of the Philippines (AFP) conducted anti-insurgency missions, 14 civilians were killed during the first half of 1997 and shortly afterwards, "10 Muslim students and a teacher" (CRHRP 1998). The commanding officers of both parties then readily agreed on monitoring the ceasefire more efficiently (Bell and Utley $2015,6)$.

Some violent clashes erupted between AFP and MILF in August 2001. The implementation of the ceasefire provision was severely endangered. As the US government was tightening its counter-terrorism policy after 9/11, Philippine president Joseph Estrada followed suit, proclaiming an "all-out war policy" aiming at suppressing autonomy endeavours. In 2003 fighting broke out between AFP and MILF (Amer and Zou 2011, 69; Özerdem 2012, 405-406).

\footnotetext{
"One of the key security challenges for the peace process in this period was the availability of small arms, which has in fact, always been a critical issue in the Mindanao context for the sustainment of the conflict. For example, over 1.3 million arms were in circulation in 2006 only half a million of which were registered, while Mindanao was home to 45 legal weapons businesses and 522 authorised arms dealers." (Özerdem 2012, 406)
}

The third-party monitoring of the ceasefire conducted by the OIC was very weak. One of the main challenges was that the OIC did not have any peacekeeping military personnel in the conflict area. A peacekeeping unit was recruited from the member states by the OIC after signing the Tripoli Ceasefire Agreement in 1976 to monitor and prevent violations in Mindanao. It utterly failed (Lingga 2006, 8). The International Monitoring Team (IMT) did not exist at that time. It was founded at a later date. In 2004, it was in charge of the monitoring of 
GRP and MILF (Herbolzheimer 2015). The US launched a tough counter-terrorism policy targeting Muslim groups after the 9/11 events. GRP reacted similarly, adopting strict military measures against insurgents.

As there had been several cases of kidnapping, AFP conducted military operations in Mindanao. Internally organized crime in the region affected the ceasefire process and the failing decommissioning of weapons facilitated the recurrence of violence. Although there were several violations of the Peace Agreement, the parties did not officially withdraw from the agreement. The OIC, the single pure mediator and arbitrator, was unable to prevent violation and peace spoilers. Nevertheless, it provided successful ceasefire mediation before the signature of the agreement and subsequently settled the dispute between the Moro Islamic Liberation Front (MILF) and GRP in Mindanao (Kohen 2006, 339). Challenging geographic conditions made proper monitoring extremely difficult.

\section{Power-sharing Transitional Government}

Governmental power-sharing was agreed upon within the framework of the Regional Autonomous Government in the peace accord which required ratification by the Government of the Republic of the Philippines (GRP). The OIC (2006) reports the issue with Muslims in Southern Philippines that GRP had failed to fulfil its commitment as stipulated in the Peace Agreement, in terms of national government positions, executive council, legislative assembly and administration. It was pointed out in the report that "the Senate and Congress, instead of ratifying the agreement, have made an organic act-RA 9054 on March 31, 2001". The government's one-sided action meant "disregarding the MNLF participation as the principal party to the agreement". The agreement could therefore not be implemented (OIC 2006, 1112). Implementation efforts varied over time, as different presidents took different approaches to solve the implementation problem: Fidel Ramos (1992-1998), Joseph Estrada (1998-2001) and Gloria Macapagal Arroyo (2001-2010). So, the OIC kept urging the Philippine government to overcome impediments. Peace policy in Mindanao was largely affected by changes in government. The OIC could not make any leverage on parties as a single, powerless third-party. 


\section{Executive Branch Reform}

Article 65 of the Mindanao agreement is an essential part of the following stipulation for executive reform: "It shall be policy of the National Government that there shall be at least one (1) member of the Cabinet (with the rank of Department Secretary) who is an inhabitant of the Autonomous Region to be recommended by the Head of the Autonomous Government." In 2005 the candidates were elected in the autonomous region of Mindanao (ARMM) but were not appointed to the executive government branches by the central Philippine government as mentioned above. They were only appointed to certain posts such as "Nasser Pangandamam, Department of Agrarian Reform, and Mr. Zamzamin Ampatuan, National Anti-Poverty Commission Chairman." (OIC 2006, 7). The failure of implementation was mainly due to the one-sided Republic Act 9054 (2001). Atty Randolph Parcasio, legal counsel and spokesperson for the Moro National Liberation Front (MNLF), criticized that "RA 9054 was passed in the Senate at a time when "nobody was looking" [...] The government was having a serious commitment problem in terms of autonomy, law-making and further rights which were stipulated in the Agreement. The MNLF continued to question the legitimacy of RA 9054 because, in their eyes, it remained violative of the 1996 Final Peace Agreement (iag.org.ph 2015)". The OIC did not appeal in due time.

\section{Legislative Branch Reform}

Although the executive council, the legislative assembly, the administrative system and representation in the national executive government council were not established as regulated in the Peace Agreement, regional legislative power (based on the Republic Act No 9054) was conveyed to the Autonomous Region in Muslim Mindanao (ARMM). Exceptions were regulated in 2001:

\footnotetext{
"(a)Foreign affairs; (b)National defence and security; (c)Postal service;(d) Coinage and fiscal and monetary policies; (e)Administration of justice. It may, however, legislate on matters covered by the Shari'ah. The Shari'ah shall apply only to Muslims. Its application shall be limited by pertinent constitutional provisions, particularly by the prohibition against cruel and unusual punishment and by pertinent national legislation that promotes human rights and the universally accepted legal principles and precepts;"' [...] (Lawphil 2018).
} 
The OIC (2006) reported that the provisions had only been partially implemented, as the stipulated changes had been made by the government unilaterally (Joshi et al. 2015). As no communication took place between The OIC and the Government, the role of the OIC was virtually insignificant.

\section{Constitutional Reform}

The constitutional reform was based on the Republic Act No. 9054 in 2001. It was carried out by the government in a one-sided manner without the participation of the OIC and the MNLF during the law-making process. The OIC was excluded from the law-making process by the Government.

\section{Inter-Ethnic/State Relationship}

Article 4 of the Agreement called for more cooperation between Muslims, Christians and other cultural communities. The Southern Philippines Council for Peace and Development (SPCPD) was established in the framework of Executive Order NO 371. It aimed at full participation of the main cultural community representations (Stankovitch 1999, 89). Following the Agreement, a Special Zone of Peace and Development (SZOPAD) was established in Mindanao, so special heed was paid to underdeveloped areas. This was one of the most important reform projects in Mindanao to promote peace, economic and social development, infrastructure, telecommunication, reconciliation between rival groups (Muslims and Christians) and, in particular, the integration of Mindanao into the Philippines (Lawphil 2018b).

Moreover, SPCPD did not have any law-making authority. While the presence of "nongovernment organizations (NGO's), and people's organizations (POs)" in the Consultative Assembly was guaranteed by the Republic Act No. 371, the OIC was excluded from direct cooperation for regional peace and development. So, it could not cooperate with other organizations in matters of regional peace and development. 
Nevertheless, the OIC kept emphasizing the significance of the provision implementation in the Autonomous Region in its reports (OIC 2006, 6). The structure and aims of the Southern Philippines Council for Peace and Development (SPCPD) are, to some extent, similar to those of COPAZ in El Salvador and the British-Irish Inter-Governmental Conference in Northern Ireland. As the OIC possessed inadequate communication skills, it was unable to develop appropriate powers of persuasion. Moreover, it was not authorized to impose sanctions against the Government.

\title{
Boundary Demarcation
}

The Peace Agreement provided for an Autonomous Region in Muslim Mindanao, in which the demarcation line was to be approved by plebiscite in specific areas. The Republic Act No. 9054 stated:

\begin{abstract}
„(1)The Autonomous Region in Muslim Mindanao which, under the provisions of Republic Act No. 6734, the Organic Act for the Autonomous Region in Muslim Mindanao, is composed of the four provinces of Lanao del Sur, Maguindanao, Sulu and Tawi-Tawi, is hereby expanded to include the provinces and cities, enumerated hereunder, which vote favorably to be included in the expanded area of the autonomous region and for other purposes, in a plebiscite called for that purpose in accordance with Section 18, Article X of the Constitution" [...]
\end{abstract}

The plebiscite in question caused incompatibilities between the Government and MNLF. The MNLF would not accept the GRP's unconstitutional referendum organized on August 20, 2001. The GRP threatened and assaulted MNLF groups for blatantly ignoring the binding referendum, eventually capturing and illegally imprisoning Leader Nur Misuari (OIC 2006, 8). The government's actions violated the ceasefire, caused a breach of confidence, severely hampered the implementation process. In August 2001, the plebiscite resulted in the creation of a new province, Basilan. "One new city, Marawi, voted to join Lanao del Sur, Maguindanao, Sulu, and Tawi-Tawi provinces in the ARMM." CRHRP (2002). The provision was partially implemented in a one-sided manner (Joshi et al. 2015). MNLF strongly opposed it.

\section{Decentralization / Federalism}

An "Autonomous Region of Muslim Mindanao "(ARMM) was required by the Congress of the Philippines. Although the Government had a commitment problem, postponing decisions, the 
reform was carried out in the Republic Act No. 9054 (2001), which guaranteed decentralization through governmental and territorial power-sharing. Although not all FMLN demands such as plebiscite were approved by the Government, the regional autonomous region was established. The provision was implemented almost completely (Joshi et al. 2015). The OIC criticized Republic Act No. 9054 for being contrary to the 1976 Tripoli and the 1996 Mindanao Peace Agreement (OIC 2006, 10).

\section{Civil Administration Reform}

The reform of the civil service commission which had not been implemented yet by the government (Joshi et al. 2015), was dealt with in Article 72 of the Agreement. No action was taken by the OIC.

\section{Judiciary Reform}

Articles 69, 70 and 71 of the Peace Agreement stipulated that the central government should employ qualified and recommended personnel from the Autonomous Region, at least one person in the Bar Council, one person in the "Supreme Court and at least two in the Court of Appeals" [...] Although those demands were to be implemented in the Republic Act No. 9054 (2001), they were never implemented (Joshi et al. 2015). Moreover, "Section E, Article 152 of the Agreement simply states, without elaboration, that the Regional Legislative Assembly of the area of autonomy shall establish Shari'ah Courts in accordance with the existing laws." (Bauzon 1999, 259). According to the OIC reports, "there are today five Sharia District Courts with two District Judges, and 30 Sharia Circuit Courts with 27 Circuit Court Judges functioning within and outside the ARMM." (OIC 2006, 7). According to Human Rights Practices (CRHRP 1996-2006) the judicial system of the Philippines was inefficient and "suffered from corruption and inefficiency". The transitional justice mechanism was not integrated into the Agreement, nor was it released in the Republic Acts, although 120,000 people had lost their life due to internal-armed conflict since 1969 (Herbolzheimer 2015). So, the provision could only be partially implemented (Joshi et al. 2015). The OIC activity could not be identified in this context. 


\section{Military and Police Reforms}

The Agreement did not provide any provisions in terms of disarmament, demobilisation or reintegration (DDR) program. Terms like "disarmament" and "demobilization" did not figure in the text because they might have been interpreted by MNLF members negatively, in terms of capitulation or total surrender (Makinano and Lubang 2001, 25). Nevertheless, a vigorous socio-economic development program was designed specifically for Mindanao (Santos 2010, 178). Articles 19.a and 20.a of the Agreement stated that 1,500 MNLF combatants in the PNP and "5,750 MNLF members" were to "be integrated into the Armed Forces of the Philippines (AFP), 250" of whom were to work in auxiliary services. The recruitment area was to be in the Special Zone of Peace and Development (SZOPAD) in Mindanao. Due to the integration program, 7,000 rebel fighters were successfully integrated into the national army and police forces. The number of MNLF fighters being integrated was considerably smaller in comparison to the former MNLF army (Santos 2010, 163). Nevertheless, this was symbolically significant in terms of the cessation of hostilities. Full implementation was achieved in terms of military reform in Northern Ireland.

\section{Reintegration}

In Article 19.a of the Agreement, it was stipulated that particular socio-economic, cultural and educational integration projects were to help former MNLF members and their families, who were excluded from the reintegration program, to enter the national security forces. Various commissions and experts cooperated in the Mindanao reintegration program (e.g., the Commission on Higher Education and National Peace Unification, Development Council). They provided training and courses in ,,agriculture, education, arts, and sciences, basic literacy programs, health and medical care", and an "internationalization program". The "Bring a Rifle Improve your Livelihood" program encouraged disarmament (Makinano and Lubang 2001, 3132; Stankovitch 1999, 280). The UN provided financial support for the integration programs through the Action for Conflict Transformation (ACT). The overall budget allocated to the Peace Program (2005-2010) amounted to 16,201,360\$ (United Nation Development Program 2018). The implementation of the integration process was achieved on account of the help of 
various commissions, groups, councils and experts. It, therefore, constituted a successful example. The OIC was playing only a minor part.

\section{Human Rights}

Human rights had only been partly respected in the Philippines for many years. According to the Country Reports on Human Rights Practices in the Philippines (1996-2006), both opposing parties violated human rights. Those violations were investigated by various NGOs and neutral observers. They were highly diversified: "arbitrary interference with privacy, family, home, or correspondence; use of excessive force and violations of humanitarian law in internal conflicts", violence against women. A ray of hope in that dark chapter of history was that the government allowed activists to investigate complaints of human rights violations throughout the country (CRHRP 1996-2006).

The CHR, its core task ought to prosecute cases of crimes against humanity, raised the volume of local monitoring inspectors; during mid-year, there are far „more than 13,000 local human rights“ personnel worldwide, up to „8,000“ at the later part of 1998 (CRHRP 2000). A great number of activists were killed. "The resulting report (the 'Melo Report') was made public on 22 January 2007. It reported the human rights group Karapatan's claim that at least 724 activists had been killed since President Arroyo came to power, Amnesty International's official list of 244 victims" (Kraft 2010, 187). The provision could not be properly implemented (Joshi et al. 2015). The OIC did not carry out any activity in that context.

\section{Education Reform, Official Language and Symbols}

In Articles 94 to 125 of the Mindanao Peace Agreement, it was stipulated that the educational system which had been under the supervision of the Regional Autonomous Government should be, from now on, by the educational policies, standards and authorities of the National Government. Articles 95 and 97 emphasized that the educational system should "perpetuate Filipino and Islamic ideals and aspirations, Islamic values and orientations of the Bangsamoro people" and should "promote solidarity, unity in diversity". Those aspirations were similar to the ones in Lebanon and Northern Ireland. There, however, the educational system could not 
promote the kind of unity and reconciliation between rival societies as could have been desired. Moreover, the educational reform proclaimed freedom of language at schools in the autonomous region. Article 114 stated that the "regional languages may be used as auxiliary official languages in the region as well as auxiliary medium of instruction and communication." The urgently required reforms in the Philippines were carried out under the Republic Act 9195 and DepED Order No. 51. The Organization of the Islamic Conference (OIC) criticized that the educational reform lacked financial funds, that Muslims were not treated equally, having any access to higher education in the Southern Philippines. The OIC promised to provide financial aid for "Muslim Minorities in the non-OIC Member States" (OIC 2006, 4-7). The provision was successfully implemented (Joshi et al. 2015).

\section{Cultural Protection}

Article 103 of the Peace Agreement structured the protection of cultural diversity, languages, values, traditions and history of Muslims, Christians and indigenous societies in education. The provision and educational reform were mainly implemented (Joshi et al. 2015).

\section{Economic and Social Developments}

In the framework of the Autonomous Region in Muslim Mindanao, the Southern Philippines Council for Peace and Development (SPCPD) was created by Republic Act Order No. 371 in 1996 and likewise the Special Zone of Peace and Development (SZOPAD) in 2001, which received international financial support from Japan etc. (The World Bank 2002). The OIC reported that the Philippine national government financed an amount of up to " 67 Billion Pesos" for the "infrastructure and other government programs" in the Autonomous Region (OIC 2006, 8). The OIC blamed the national government's discrimination policy and unfair distribution of wealth, as, in their view, the government-controlled the "natural resources in the Muslim areas" and was responsible for the underdeveloped conditions in Mindanao (OIC 2006, 6). The Philippines Country Report on Human Rights Practices (1997) reported that Nur Misuari had been complaining that the country's financial assistance for the zone remained insufficient, and also that new employment and spending fell short of expectations (CRHRP 1998). The Asian Development Bank stated that the Muslim provinces in Mindanao lagged "behind the rest of 
the island in almost all aspects of socio-economic development" in 1998 (CRHRP 1999), 10 years after the signature of the Agreement, the CRHRP (2006) estimated that the "percentage of the population under the poverty level in the Autonomous Region in Muslim Mindanao (ARMM) was almost twice as high as the national average, with per capita income of $\$ 309$ (P15,760) per year." Regional economic and social development plans (e.g., establishing an Islamic Bank) and further financial support for the region were postponed for many years. Implementation was only partially achieved (Joshi et al. 2015).

\section{Ratification Mechanism}

Although the Philippine government had passed republic acts in favour of Mindanao autonomy, the SZOPAD and the SPCDP, The OIC $(2006,11)$ still criticized the national government's strategy of ratification and its implementation plan as follows:

\footnotetext{
"Phase two of the September 2, 1996 Peace Agreement can never be implemented because the Senate and Congress, instead of ratifying the agreement, have made an organic act-RA 9054 on March 31, 2001, as a solid stumbling block on the path towards the implementation of PA 1996. The GRP has already violated the PA 1996 unilaterally by disregarding the MNLF participation as the principal party to the agreement, let alone the OIC, in any plan of action."
}

The government had been acting in an exclusionary behaviour. The cooperation between the OIC and the government had failed. The OIC was simply too inactive, failing to provide an incentive to the government. The provision was partially implemented (Joshi et al. 2015).

\section{Donor Support}

Article 12 of the Peace Agreement stated that the OIC's assistance was needed to finance the implementation process. So, the $\mathrm{OIC}$ and several single countries participating in the GoPUN/Multi-Donor Program financially supported the Southern Philippines in its economic and social development and helped to provide sustainable peace for more than ten years. Between 1997 and 2000, the program funded \$40 million (UNDP 2003). Moreover, at the same time, the US-funded \$2.15 million for "NGO activities" in Mindanao (Heard and Magno 2000, 2). During and after the implementation period, the Philippines and the Autonomous Region in Muslim Mindanao (ARMM) received further financial support. All in all, the provision was 
fully implemented (Joshi et al. 2015). Lack of external financial support had delayed the implementation process.

\section{Detailed Implementation Timetable}

The Peace Agreement had set up specific dates concerning constitutional lawmaking and further reforms for Mindanao (referendums, Special Zone of Peace and Development in the Southern Philippines (SZOPAD). Nevertheless, the implementation process was repeatedly postponed. This was due to several reasons: ceasefire violations, financial shortcomings, constitutional reviews, exclusion of conflicting parties, timing incompatibilities as to referendums and national elections. Further reasons for the delay are identified by DictaanBang-oa $(2004,161)$ : Trust was a huge barrier for the Moro people. Trust was difficult to come by, particularly in the government, which had failed to demonstrate its seriousness in resolving their complaints. The administrative strategy, a lack of resources among supporters, and the lack of access of project areas, among other factors, have all led to the lag in execution, according to project implementers.

The OIC as the main third party and other external actors utterly failed to accelerate the proceedings. As mentioned before, delays always constitute a risk that the agreement might be violated by spoilers. In the case of the Philippines, this risk was identified by Dr. Danda Juanday, a member of the board of the Bangsamoro Development Council and executive director of the Bangsamoro Development Agency. He feared that "delaying the negotiation will give way to the breaking up of the Moro front into small groups which will be an invitation to "catastrophe". There are radical members of the Moro front who might take over the moderates." (Ampatuan et al. 2010, 40). Ten years after the implementation period, several improvements had been achieved in Mindanao which is not being discussed in this thesis, as they did not occur in the time set in this thesis. The OIC were unable to pressure the government into accelerating proceedings. The provision was partially executed (Joshi et al. 2015). 


\section{Natural Resources Management}

Articles 134, 143 and 147 regulate the issue of mining and mineral processing in the Autonomous Region in Muslim Mindanao (ARMM). Article 147 stated that the strategic minerals should be defined later and be shared equally between the government and the ARMM. Although Mindanao is very poor compared to other regions in the Philippines, it is very important to the national wealth of the whole country in terms of mineral resources and productions. Alparslan Özerdem emphasizes that the region "produces 90 per cent of the iron ore, 89 per cent of the nickel and cobalt, 62 per cent of limestone, almost 100 per cent of all the banana and pineapple exports, 50 per cent of all the corn and coconut, 50 per cent of all the fish, 40 per cent of all the cattle and 20 per cent of all the rice.” (Wolff and Dursun-Özkanca 2016, 399). The Republic Act 9054 Art X (2001 stated new regulations as to tax collection, defining strategic minerals, the inhabitants' preferences for mineral processing (Lawphil 2018). The OIC strongly criticized the government's one-sided decision on strategic mineral regulation, blaming the government for having violated the Peace Agreement.

\footnotetext{
"The GRP, acting through Congress, has unilaterally arrogated to itself the power to define strategic mines and minerals, which violated Paragraphs 146 and 147 of 1996 PA. This contravenes the agreement, which mandates that the MNLF and the GRP, with the positive contribution of the technical experts of the OIC, will mutually agree on the definition of the strategic mines and minerals on a later date." (OIC 2006, 9)
}

The regional recovery was not as effective as expected. The provision was not implemented as agreed (Joshi et al. 2015). The OIC did nothing else but report about the lack of implementation.

\section{Review of Agreement, Verification and Monitoring Mechanism}

Articles 12 and 13 of the Agreement gave authority to the OIC and other parties to review the implementation process. The OIC's first general and comprehensive review was reported 10 years after the signature of the agreement. The OIC did not regularly issue any reviews. When it issued its reports, they were not considered adequate by the Government. The provision was implemented in a sluggish manner (Joshi et al. 2015). 


\section{Result}

24 different provision types were involved in the Mindanao Final Agreement (MFA). Examining each provision one by one, over 10 years, reveals under what conditions they could be implemented or not. Articles 12 and 13 of the Mindanao Final Agreement (MFA) gave authority to the Organization of Islamic Conference (OIC) as the third party assisting, to guarantee and monitor the implementation process. The OIC's mediation in the Mindanao peace process has the features of a single pure mediator. There was also the considerable impact of the Organisation of Islamic Countries (OIC) as a third party and of other independent organizations on the peace process (1996 - 2006). The Country Reports on Human Rights Practices on the Philippines between 1996 and 2006, submitted annually by the U.S. Department of State to the U.S. Congress, greatly contributed to this purpose.

The OIC Secretary General Prof. Ekmeleddin Ihsanoglu pointed out that partial success in Mindanao had been achieved after the 10-years long peace process: "Regrettably, this peace agreement did not bring real peace. Disagreement on the interpretations of some provisions of the agreement led to resumption of hostilities" (Lingga 2006, 9). The OIC was less capable of achieving a successful peace agreement implementation in Mindanao. The main obstacle to implementation was that the government acted in a one-sided manner, releasing the Republic Acts, systematically discriminating against the OIC in the implementation process. The OIC was too weak to put pressure on the government and did not ask the UN for help. However, it operated successfully as a short-term mediator in agreements as to ceasefire. "According to Misuari, the talks and the agreement would have been impossible without the OIC because the MNLF was determined for sovereignty” “(Stankovitch 1999, 76). Although the peace agreement was an extremely arduous task, the implementation of the MFA scored as much as 59\% (Joshi et al. 2015). If countries or organizations (e.g., US, Malaysia, Australia, UN, ASEAN) or a strong coalition of third parties had pressured the Philippine government into seriously overcoming commitment problems, the peace process would have been far more successful. The US, in particular, had close relations with the Philippine government and it had succeeded in El Salvador at a moment when the implementation process had come to a standstill there. However, as it had shifted its international security policy against Muslim insurgents after $9 / 11$, the US playing the role of facilitator in Mindanao was out of the question. So, 
ASEAN could have been a powerful actor. It was not involved in the peace talks, although one of its purposes is "to maintain and enhance peace, security and stability and further strengthen peace-oriented values in the region" (The Association of Southeast Asian Nations 1967, 3). The UN did not engage in the peace process as a third-party either. Nevertheless, it provided financial support for integration programs through the Action for Conflict Transformation (ACT). As it was successful in El Salvador and was supported by the US, it could have contributed to better implementation as a neutral and powerful international third-party in Mindanao. International and regional organizations and third countries are not always interested in being involved for various reasons (i.e., personal capacity, financial issues or authorizations).

There was always the danger that the fragile agreement would be shattered. MNLF rejected a plebiscite conducted by the Government. "For refusing to accept the said plebiscite the GRP provoked and attacked MNLF forces and finally arrested illegally detained Chairman Nur Misuari" (OIC 2006, 8). The government's action violated the ceasefire, caused a breach of confidence and violated the demarcation of territorial lines. All this could have been prevented if power mediators had been there.

Including territorial or governmental power-sharing provisions in peace, agreements increase the chance for successful implementation in the long run. Power-sharing was partially implemented in terms of extensive, territorial power-sharing provisions (Joshi et al. 2015). Implementation efforts in terms of power-sharing varied over time, as different presidents took different approaches to solve the implementation problem. When the Autonomous Region of Muslim Mindanao (ARMM) was established, there was no third-party security guarantee during the implementation process. The presence of UN peacekeeping forces would have balanced the power and improved security guarantee, enforcement and confidence building. As the Philippine government remains pragmatic and is likely to change its policy regarding Mindanao because of national elections, the peace process might be jeopardized and engender a new conflict in future. To avoid it, the peace process should be regularly monitored by multiple third parties. 


\subsection{Comparative Case Analysis}

\subsubsection{Implementation of Ceasefire Arrangements}

„Ceasefire agreements, or the first or last in a series of agreements, does not include any resolution of the incompatibility. Typically, ceasefires are but concerned with ending the use of force by the warring sides“ (Kreutz 2010). The termination of an armed conflict can be temporary or permanent in a particular area. Its implementation can be effectively consolidated by mediators providing regular monitoring, assistance and security. As ceasefire agreements usually occur before signing peace agreements, which opens the way to peace-talks, some countries have reached ceasefires only after peace agreements. Ceasefire implementation is to be found in all of the four selected cases. The success level of ceasefire implementation was achieved differently by single or multiple mediators, pure or power mediators.

The United Nations Observer Mission in El Salvador (ONUSAL) acted together with COPAZ as third parties, assuming the prime responsibility for the ceasefire implementation mandated by the Security Council, resolution 693 on 20 May 1991. COPAZ, the commission aiming at peace consolidation, was established to monitor the implementation process in El Salvador. It was supported by the UN. In the case of uncertainties and disputes, COPAZ as the ad-hoc commission took charge of identifying obstacles, finding solutions, reporting on the peace process and consulting the conflicting parties. In El Salvador, the ceasefire was implemented after signing the peace agreement, which was fully acknowledged as a provision in 1992 (Stedman et al. 2002, 389). The ceasefire was successful for some time, as the conflicting parties were seriously committed to proper disarmament, demobilization of paramilitary groups and rebels on a set schedule. Some problems arose because of land issues, delaying the implementation process. The land issue was finally resolved due to the strategic coordination of the UN and COPAZ in cooperation with rival parties (UN 1992, 5).

When FMLN had failed to destroy all its weapons in 1993, the implementation process was at stake (Montgomery 1995, 140). It had also secretly delivered weapons to Nicaragua, which again seriously delayed implementation proceedings. Moreover, an armed group of peace spoilers were identified, the anti-communist "death squads" which had been established by former military and police members (UN 1994, 3). They carried out assassinations of former 
FMLN combatants in different locations. Violence increased prior to the general elections. Human rights violations and complaints were regularly collected by ONUSAL. Close communication and cooperation between ONUSAL, COPAZ, the Salvadorian Government and FMLN prevented further violation of the ceasefire. The Government took action against illegal groups, investigating each case and punishing the perpetrators (ibid. 4-6). Multiple mediators continuously put pressure on the conflicting parties, admonishing them to strongly commit themselves to the implementation of the ceasefire. The successful coordination of those third parties will be dealt with more closely in Chapter VII, Cessation of the Armed Forces (BoutrosGhali 1995, 211). Studemeister strongly suggests that mediators monitor processes very closely and cooperate with actors (Studemeister 2001, 39). As uncertainty might violate the ceasefire progress, disputed issues should be resolved during peace-talks and not be postponed to postagreement periods. The success of the ceasefire mainly depended on the third parties' coordination and commitment to a scheduled plan providing proper disarmament and demobilization of paramilitary groups and rebels. Securing ceasefire was hampered by rivalling political parties after the election.

External third-party mediators repeatedly warned the conflicting parties of the imminent danger of peace spoilers but failed to prevent acts of violence. The close cooperation between ONUSAL, COPAZ, the government and other civil societies facilitated the implementation process and banned peace spoilers. Signatory parties are continuously warned by third parties to distance themselves from splintering groups and other paramilitary armed groups in postagreement processes. As to El Salvador, the presence of the UN could not prevent minor ceasefire violations which might have endangered the entire peace process. In Northern Ireland, splinter armed groups (e.g., the Real IRA) were established by separatists who opposed the peace agreement. They were neither supported by the signatory parties nor the citizens of the post-conflict society. In Lebanon, the former army commander did not recognize the peace agreement, putting the ceasefire at risk. For that reason, power mediator Syria and various splinter groups waged war against each other. Thanks to Syria's military power, massive peace spoilers were kept away. If multiple power mediators had been in charge of the implementation process, the armed conflict between Syria and the Maronite general could have been avoided in a joint effort of intensive communication. 
In Mindanao (Philippines), several ceasefire arrangements were identified before the signature of the peace agreement between the GRP and MNLF. Some were long-lasting but not sustainable. The Mindanao Final Agreement did not specify any particular ceasefire provisions, as several ceasefire agreements had already been achieved previously which had paved the way for peace talks and the Final Agreement. The OIC, a joint committee of MNLF, and the government were appointed to monitor and implement the ceasefire following the Tripoli Agreement (1976). However, one of the main conflicting parties in Mindanao, the Moro Islamic Liberation Front (MILF) was reluctant to comply with the Mindanao Final Agreement. This could have severely hampered the ceasefire. MILF and the "government signed a ceasefire agreement in 1997" (CISAC 2019; Stankovitch 1999, 89) and likewise the new Tripoli Peace Agreement in 2001, which was crucial to the success of the implementation of the ceasefire (Amer and Zou 2011, 69).

According to the Country Reports on Human Rights Practices in the Philippines, several violent clashes occurred in Mindanao. When the Armed Forces of the Philippines (AFP) conducted anti-insurgency missions, a numerous civilian was killed (CRHRP 1998). The commanding officers of both parties then readily agreed on monitoring the ceasefire more efficiently (Bell and Utley 2015, 6). Due to several kidnapping cases, AFP kept conducting military operations. Some violent clashes erupted between AFP and MILF in August 2001. Implementing and guaranteeing the ceasefire were severely endangered due to other conflicting parties in Mindanao. As the US government was tightening its counter-terrorism policy after 9/11, Philippine president Joseph Estrada followed suit, proclaiming an "all-out war policy" aiming at suppressing autonomy endeavours. In 2003, fighting broke out between AFP and MILF (Amer and Zou 2011, 69; Özerdem 2012, 405-406). Compared to the positive effect of third parties on the ceasefire in Northern Ireland, Lebanon and El-Salvador, the consolidation of the ceasefire proved weak in Mindanao. The OIC, acting as a single pure mediator, failed to guarantee the non-resumption of hostilities. It neither had any military peacekeeping personnel nor any field experts. Monitoring proved difficult because of the difficult geographical circumstances. Although peace negotiations were repeatedly suspended because of renewed armed conflicts involving large numbers of casualties, the agreement in Mindanao was considered successful on official terms. 
As the failure to decommission weapons facilitated the recurrence of violence, organized crime hampered the ceasefire process in Mindanao. Despite serious violations of the peace agreement, the third parties did not abandon their efforts to achieve an effective ceasefire. The OIC provided successful ceasefire mediation before the signature of the agreement and settled the dispute between the Moro Islamic Liberation Front (MILF) and GRP in Mindanao (Kohen 2006, 339). The UN and the OIC are pure mediators belonging to international organizations. However, the UN's power to communicate and cooperate with implementers is by far larger than the OIC's. This makes a big difference in matters of success. As the UN closely cooperated with COPAZ and other local actors in El Salvador, this facilitated countrylevel control over the ceasefire.

The OIC identified implementation problems in terms of peace spoilers. It very irregularly reported on the problems in Mindanao and did not take any initiative to prevent violations at the right time. Its lack of regular communication and cooperation with local and national actors considerably slowed the peace process down. This corroborates the assumption that to enhance the successful implementation of the ceasefire, sharing responsibilities among multiple pure or power mediators is by far more effective than single pure or power mediators acting by themselves. Besides, the UN is being a pure mediator, has more leverage and facilitation impact than the OIC to prevent ceasefire violations because the UN Security Council is authorized to impose sanctions against governments. Both pure mediators, the UN and the OIC, equally face the same challenges to prevent peace spoilers. Only close cooperation with the conflicting parties and shared interest in the implementation process can minimize the risk of spoilers. If there had been one more mediator in Mindanao, he would have been able to consolidate the ceasefire implementation more effectively. It implies that uncertainties, the absence of multiple and powerful mediators give more strength to peace spoilers. Proper ceasefire implementation needs specific solutions and a fixed schedule. In that regard, the Chapultepec Agreement was more clearly conceived than the Ta'if Peace Accord and Mindanao Peace Agreements. Accuracy is one of the key elements of the implementation process, eliminating uncertainties.

In Northern Ireland, the ceasefire provision was not dealt with in the Good Friday Agreement. Unlike the ceasefire in El Salvador, the ceasefire in Northern Ireland was first declared by the 
IRA and some rival paramilitaries in 1994, before the peace agreement was signed (Connolly 2006, 412). The ceasefire decision was taken unilaterally by the IRA, which could be interpreted as a result of secret talks (Debraggio 2010, 32; Nolan 2012, 21). The ceasefire deals greatly facilitated the negotiations between the governments of the Republic of Ireland, the UK and the warring parties in Northern Ireland. When the British Government and the IRA disagreed on the deadline for decommissioning arms, the ceasefire was violated by the IRA in 1996 (Debraggio 2010, 33; Mac Ginty et al. 2007, 6). A lasting ceasefire was closely related to disarmament which was fully supported by multiple powerful third parties. Therefore, it was generally assumed that the peace process should commence with the decommissioning of IRA weapons. At a later date, the decommissioning process was successfully completed in the postagreement period in 2005 (BBC 2009). An obstacle to the ceasefire implementation occurred when a new armed group that had split from the IRA emerged. This splinter group posed a serious threat to the ceasefire. In 1999, the issue of decommissioning arms reoccurred in the peace process. The then Prime Minister Tony Blair greatly contributed to resolving the problem of "the decommissioning of paramilitary weapons and the release of paramilitary prisoners" (BBC 2017a). In that context, British peace facilitation in Northern Ireland was similar to US peace facilitation in El Salvador. However, there was no US peace facilitation in Mindanao.

Eight years after the signature of the GFA, the British-Irish Intergovernmental Conference (BIIC) reported that one of the last remaining paramilitary groups, PIRA, had officially declared the termination of armed actions in favour of lasting peace (BIIC 2006). Although there had been various attempts at violating the peace talks before and after the signature of the peace agreement, the leaders of the main parties remained patient, fully determined to secure peace and prevent peace spoilers. The intensive dialogues between the multiparty commissions such as the British-Irish Intergovernmental Conference, the British-Irish Council and the Independent International Commission on Decommissioning (IICD) ensured the ceasefire. These groups also closely monitored the ceasefire. Their role in the peace process resembles the role COPAZ played in El Salvador. However, international monitoring of ceasefire was missing in Mindanao and Lebanon. The completion of decommissioning (disarmament) was the last stage of the ceasefire process in Northern Ireland. In comparison to El Salvador, the ceasefire in Northern Ireland began before the IRA and some rival paramilitaries signed the peace agreement in 1994. The then Prime Minister Tony Blair helped to solve the problem of 
mutual trust. Intensive dialogue meetings were held in which multiparty commissions emphasized their cooperation and ensured the success of the ceasefire implementation (BritishIrish Intergovernmental Conference, British-Irish Council, Independent International Commission on Decommissioning). In contrast, Syria (power mediator) used its great military power to enhance the ceasefire in Lebanon. In Mindanao, the single pure mediator OIC was unable to prevent any ceasefire violations, as it acted alone and did not have the capacity to prevent it. It did not show much interest in the implementation process either. In Lebanon, Syria could have stopped ceasefire violation after the armed conflict had come to an end.

Thanks to the third parties' mediation efforts numerous ceasefires were achieved in Lebanon. The last ceasefire was violated by former military general Aoun, whose army was defeated by the Syrian troops. Although the UK and the Republic of Ireland (power mediators) had sufficient military capacity to guarantee the ceasefire in Northern Ireland, they primarily used communication, providing a guarantee, technical assistance and dialogue. Syria, however, exerted its military power to enhance the ceasefire which resulted in a large number of casualties and triggered off new hostility. It put the rival parties in an uncomfortable situation and diminished public confidence. Its single military presence in Lebanon led to high uncertainty among Christians. Multiple mediations involving France, the US or the UN could have resolved the internal, military power-sharing arrangement more effectively. It could have brought about a stable armistice which would have inspired confidence in the peace process. Multiple mediations would have kept a proper balance of power between the rival parties.

Based on the findings in the comparative case analysis, it can be assumed that multiple pure mediations or multiple power mediation are more successful than single pure mediation or power mediation to enhance ceasefire implementation in a post-conflict country. It implies that multiple mediators are more effective than single mediators. The two mediator types have different characteristics. Power mediators generally display military capacity, leverage, financial power, whereas pure mediators are believed to exhibit communication and facilitation skills. However, power mediators can also display characteristics generally attributed to pure mediators and vice versa. So, a power mediator may equally display communication and facilitation skills like a pure mediator. This was the case in Northern Ireland, where the Republic of Ireland and the United Kingdom displayed facilitation and communication skills 
simultaneously throughout the entire peacebuilding process. However, if a pure or single power mediator were to act solely, his individual skills would be weakened. So, both types of mediators (power and pure) should exploit their full potential of communication, facilitation and persuasion to convince the rival parties to avoid military leverage. If the mediators are multiple in the field, they can share responsibility for ceasefire implementation in different parts of conflict zones. They are more able to provide confidence-building, solve commitment problems, prevent peace spoilers and enforce security guarantee in post-conflict societies.

\subsubsection{Implementation of Institutional-governmental Power-sharing}

Achieving institutional-governmental power-sharing in conflict zones was an important goal after the ceasefire had occurred and the peace agreement had been signed. In El Salvador, the following actions were primarily taken to provide services for a post-conflict society: new setting of the administration of justice, effectiveness of the legislative, functioning of nongovernmental organizations, guaranteeing FMLN members the full exercise of their civil and political rights (Boutros-Ghali 1995, 218). Within the framework of institutional reform, the government officials such as former court judges and mayors in exile were requested to return to the conflict zones. However, the return of those officials was made difficult, as FMLN and some local communities raised concerns against that project. Eager to resolve those issues, ONUSAL appealed to the local communities to strive for more communication and overcome that problem to achieve lasting peace and reconciliation. A collaboration agreement was signed by the opposing parties, allowing officials to return to El Salvador (16 September 1992). The agreement had been achieved through joint action, by ONUSAL and the Supreme Court of Justice (ibid. 278). As a result, the implementation of the civil administration reform was successfully accomplished in 1994. If a single, pure third-party had been trying to achieve the same result independently, it might have failed to enhance implementation because of the lack of communication. Similarly, the OIC was not able to support governmental power-sharing on its own in Mindanao. Thanks to the efforts of third parties, the establishment of governmental power-sharing was successful in Northern Ireland and Lebanon. 
In El Salvador, the Secretary-General stated that the implementation of power-sharing had been delayed due to the lack of "financial funds and resources" (ibid. 589). In this context, the financial sponsoring of power-sharing implementation is of great importance. Thanks to its credibility and reliability, the UN succeeded in raising funds for the implementation process. In contrast, the IOC, the other pure mediator, was financially weak and unable to support the implementation process financially. In Northern Ireland, money was not an issue as the two power mediators were able to arrange enough financial support. Syria (single, power mediator) was unable to solve the financial problem in Lebanon.

In El Salvador, the constitutional reform was implemented by the UN and COPAZ. It emphasized the armed forces, the electoral system and the judicial system. Those sections were implemented in 1992/1993 (Joshi et al. 2015). In Northern Ireland, institutional changes given a constitutional reform took place following the peace agreement. The territorial definition of the border in Ireland required an amendment in the Constitution of the Irish Republic. The constitutional reform was implemented by referendum in the Republic of Ireland on 22 May 1998 (CAIN 1998). As a result of this reform, the Republic of Ireland no longer makes territorial claims to Northern Ireland. The right to self-determination was achieved by a referendum in Northern Ireland in 1998 (ARK 2002). Accordingly, the right to selfdetermination was guaranteed and implemented there. Brexit might affect Northern Ireland's economic, social and foreign affairs with the EU and the UK in the long run. It might also affect the integration process of Unionists and Republicans (pro- or anti-EU). New border restrictions with the Republic of Ireland might constitute new difficulties. This could result in a new referendum in favour of a United Ireland. The multiple mediators utilize their communication and facilitation power for institutional-governmental power-sharing. The constitutional reform in Mindanao was carried out by the government in a one-sided manner without the participation of the OIC. In Lebanon, constitutional reform was lacking and only in 1999 did the Syrian government put pressure (leverage and enforcement) on Lebanon to initiate further implementation actions.

Paving the way for FMLN to establish their political party, the legal basis was established by the legislative assembly which allowed pluralism. Promoting the political participation of former rebel groups was one of the key factors for sustainable peace and good democracy. This 
enhanced governmental power-sharing, which is considered by many researchers as an essential element for peacebuilding (Hartzel and Hoddie 2003, 321). This was to be FMLN's first step towards political participation. As ONUSAL raised concerns as to FMLN's credibility during the implementation process of an electoral/political party reform in May 1992, the government delayed legalizing FMLN as a political party (Boutros-Ghali 1995, 245). Moreover, the parties interpreted the stipulations to be implemented differently, thus adding further delay to the implementation process. ONUSAL got the process back on track. The land issue was one of the central points of conflict which was finally solved by ONUSAL. The leaders of the two conflicting parties kept in touch with the Secretary-General by telephone. He expressed his disappointment to them about the implementation delay. After their telephone conversation, both parties promised to get the implementation back on the right track. ONUSAL's communication and facilitation efforts could not have been better (ibid. 245-246).

FMLN finally participated in the 1994 elections for the first time in its history. As the Government had required monitoring for those elections, ONUSAL established an electoral assistance division (Unruh and Williams 2013, 442). However, the registration of voters proved partially inefficient (Boutros-Ghali 1995, 51). In the end, the overall conduct of the elections was successful and in full compliance with ONUSAL's monitoring plan. Similar monitoring efforts made by third parties could not be identified in Lebanon or Mindanao. Granting amnesty to former FMLN members and establishing a new legal basis for their equal political participation in the upcoming elections were indeed significant domestic events in El Salvador. Those provisions strongly supported governmental power-sharing and thus contributed to ensuring peace, which is generally considered as one of the main factors of securing peace. One problem occurred, when the agreement dealing with certain provisions was interpreted differently by each of the conflicting parties, as some passages of the agreement had been formulated inaccurately. The problem was resolved by the Secretary-General, Mr. Handals, the FMLN leader, and El Salvador's President Cristiani. The cooperation between the third parties and the signatory parties was not always as effective as required. In Mindanao, there was no cooperation between the Government and the OIC. 
In El Salvador, the judicial system was to be newly reformed following the internationally recognized values of universal human rights such as the division of powers (Boutros-Ghali 1995, 167-168). In 1992, a delay of implementation was experienced due to the "tightness of the timetable" (ibid. 266). That issue was solved by ONUSAL's Under-Secretary-General Marrack Goulding. He repeatedly organized consultations with the parties involved and delays were regularly reported by ONUSAL (A/47/968 S/26033) (UN 1993, 36-38). Also, several postponements were identified due to the lack of ratifications, of coordination, of capacity for investigation, due to the lacking political will of government officials, due to a sluggish and languid criminal justice system (UN 1997b, 4-19). The UN levelled further criticism at the lack of implementation in the judiciary and identified further shortcomings. Many issues in terms of the judiciary were resolved by Under-Secretary-General Marrack Goulding (ONUSAL), who personally intervened. Although the UN criticized the slow implementation processes, it abstained from imposing sanctions against El Salvador.

On the contrary, several recommendations were made by the UN to facilitate the implementation of provisions soon. In Lebanon, the judiciary reform was regulated in the Ta' if Agreement (1989). The partiality of the judiciary was repeatedly criticized in the report on human rights practices. It was argued that local or national powers such as the militias at a local level, influential politicians or Syrian intelligence officers constantly intervened "to protect their supporters from detention and prosecution" (CRHRP 1989, 1471; CRHRP 1990, 1525; CRHRP 1991, 1488; CRHRP 1992, 1047; CRHRP 1994; CHRRP 1995). Although the implementation of judiciary reform took place in 1989 without any noticeable resistance, the lack of impartiality seriously affected the reputation of the judiciary. Moreover, the interference of the Syrian intelligence service in the Lebanese judiciary shed light on Syria's selfish political intentions. It implies that as long as Syria as a single mediator had free rein in Lebanon, it could not be bothered about improving implementation processes there. If multiple mediators or INGOs had been actively involved in the peace processes in Lebanon and Mindanao, they could have made sure that all mediators equally supported the implementation processes there.

As to judiciary reform in Mindanao, the Reports on Human Right Practices (CRHRP 19962006) stated that the judicial system of the Philippines also "suffered from corruption and inefficiency" over a long time. The OIC reported that the stipulated reforms in the ARMM had 
been successfully carried out. The implementation was conducted without any direct involvement of the OIC. In Northern Ireland, the judiciary reform for institutional arrangements was stipulated in the agreement that a review group should be formed to establish a functioning and equitable criminal justice system with an effective legal prosecution for the communities. This group made "294 recommendations" and brought about plenty of improvements concerning the Northern Ireland Parliament (United States. Congress. Commission on Security and Cooperation in Europe 2005, 37-38). However, the amending proposals failed to reform criminal justice in Northern Ireland at that time. Although the members of the British-Irish Intergovernmental Conference regularly discussed the significance of implementation and emphasized the importance of cooperation regarding criminal justice, only several changes were made in public prosecution (2005) and policing (2006) (BIIC 2006). It took ten years altogether to complete the implementation process employing the direct involvement of third parties and commissions. In other cases, a review group for the judiciary was not formed by mediators. In Lebanon in term of administrative power-sharing, the names of sects or denominations did not figure on identity cards anymore. The new selection criteria for employment were agreed upon in terms of qualification requirements and not based on confession (UN Peacemaker 1989). The final implementation was achieved by Prime Minister Hariri (1993-1997). He successfully performed other implementation activities in administrative issues (El- Zein and Sims 2004, 280). As things had gone out of control in Lebanon, Syria assumed a long-term mediation responsibility to pressure the conflicting parties into reaching mutual understanding.

As there was no governmental spirit of compromise in Lebanon, a problem occurred which was similar to the one in El Salvador (misinterpretation of legal texts). The provision to be implemented was interpreted differently by the conflicting parties, each of them seeking its advantage. In such conflicts, legal experts and short-term mediators should closely cooperate with long-term mediators to clarify the implementation details. Although administrative decentralization and governmental power-sharing were the essential elements of the Ta' if Peace Accord for Governorates and Municipalities, they were not implemented (Karam 2012, 38; Harb and Atallah 2015, 188). The main obstacle to achieving decentralization was the general fear of confessional secession at a national level (Harb and Atallah 2015, 192). 
To guarantee the representation of different religious communities, the number of parliamentary seats was increased to 128 and equally shared between them (Salloukh 2006, 644). Although the confessional, political system in Lebanon has always been a highly controversial topic, structural sectarianism and confessionalism have helped to enhance the country's national unity in the post-war period. Christians protested against elections because of the presence of Syrian troops in Lebanon (CHRRP 1992, 1049). Syria misused its presence in Lebanon to influence domestic policy for its benefit. The rights, duties and obligations of the President of the Republic, the Prime Minister and the Cabinet were explicitly determined. This reform faced serious obstacles, after the newly elected Maronite president, Rene Moawad (Cristian Maronite), had been assassinated in November 1989. Assassinations are disastrous peace spoilers. Mediators in the four selected cases were unable to prevent them. Another Maronite, Elias Hrawi, was elected president by Parliament. If Syria's military intervention in Lebanon had not occurred, previously armed groups would have preserved their political and military status quo, which would have seriously hampered the implementation process. So, the power of balance was maintained by the Syrian army. The struggle against an internal armed force was put to an end by third parties having a strong military capacity over a long time. In the other three cases (El Salvador, Northern Ireland, Philippines), military intervention initiated by mediators was not an option.

The first national election in Lebanon (1992) did not fulfil the required standard of quality one might have expected to expect in terms of security compliance and full participation of all parties (CHRRP 1994). The implementation process was very much in favour of Syria playing the role of the third party, although Syria's political influence was not apparent at first glance. In contrast, the Northern Ireland elections took place on 7 March 2007, after the issue of the IRA's disarmament had been resolved thanks to the strenuous efforts of the third parties organizing multilateral meetings and inspections of independent monitoring groups. Sinn Fein and DUP increased their numbers of parliamentary seats compared to the previous elections in 1998. The power-sharing of the executive was maintained at the same level as in the 2007 elections. The governmental power was now adequately shared in Stormont. The main obstacle to the implementation of the power-sharing provision was the delayed decommissioning of weapons, as the IRA had been reluctant to disarm. There was also a great deal of mutual distrust 
which severely hampered implementation. The third parties' strong commitment and Tony Blair's promising, personal promise finally helped to resolve the decommissioning problem. In contrast, the OIC was incapable of controlling the disarmament or reintegration of former fighters in Mindanao. The President of the OIC never communicated personally with the leaders of the conflicting parties in Mindanao, as implementations were in a deadlock there.

The transitional power-sharing government came into action in the transition process from war to peace, in which the former conflicting parties were to share the power of a state apparatus such as executive, legislative and judicial power. In Lebanon, the new power-sharing transition government decreed that the President would have to be a Maronite, the Prime Minister a Sunni Muslim, and the Speaker of the Chamber of Deputies a Shi'a Muslim. Lebanon and Syria signed a mutual accord that underlined the strategic cooperation of both countries and in which Syria was to provide security to Lebanon. The implementation of this accord secured Syria's guardianship in Lebanon. Syria guaranteed the successful implementation of governmental power-sharing.

The Philippine Government failed to implement the reform of civil administration according to Article 72 of the Agreement (Joshi et al. 2015). In terms of boundary demarcation, the Peace Agreement provided for an Autonomous Region in Muslim Mindanao, in which the demarcation line was to be approved by plebiscite in specific areas. The plebiscite caused incompatibilities between the Government and MNLF. As a result, government forces attacked MNLF (OIC 2006, 8). The Government's activities caused a breach of confidence and hampered the implementation process. The OIC reported that in August 2001, the plebiscite had resulted in the creation of a new province, Basilan. MNLF strongly opposed it. As to decentralization by Article 2 in the Peace Agreement, an amendment concerning the Autonomous Region of Muslim Mindanao (ARMM) was required by the Philippine Congress. Although the government had a serious commitment problem and decisions kept being postponed, the reform was carried out in the Republic Act No. 9054 (2001), which guaranteed decentralization through governmental and territorial power-sharing. Although not all of FMLN's demands (plebiscite) were approved by the Government, the regional autonomous region was established. The OIC only criticized the Republic Act No. 9054, for being contrary to the Tripoli and Mindanao Peace Agreements (OIC 2006, 10). In contrast, the multiple 
mediators in El Salvador closely communicated with the Salvadorian Government in every single step of implementation failure. The same efforts were made by the multiple mediators in Northern Ireland.

Article 65 of the Mindanao Agreement is an essential part of the reform of the executive. In 2005 the candidates were elected in the autonomous region of Mindanao (ARMM) but were not appointed to the executive branches of the Government by the central Philippine Government as stated in Article 65. The failure of implementation was mainly due to the Government's one-sided Republic Act 9054 (2001). Atty Randolph Parcasio, the legal counsel and spokesperson for the Moro National Liberation Front (MNLF), criticized the Senate's delaying tactics (iag.org.ph 2015). The OIC remained passive. If there had been an international committee in charge of the implementation of institutional-governmental power-sharing, democratic processes would have been more respected. The government was having a serious commitment problem in terms of autonomy, law-making and further rights stipulated in the Agreement. MNLF continuously questioned the legitimacy of the Republic Act because, in their opinion, the Republic Act had violated the 1996 Final Peace Agreement. The OIC did not engage in any dialogue with the Government to solve commitment problems. In El Salvador and Northern Ireland, the multiple third parties were striving hard to avoid commitment problems and fulfil the criteria laid down.

Article 4 of the Mindanao Agreement called for more cooperation between Muslims, Christians and other cultural communities in terms of "inter-ethnic/state relationship". The Southern Philippines Council for Peace and Development (SPCPD) was established in the framework of Executive Order NO 371. It strove for the full participation of the main cultural community representations. By the agreement, a Special Zone of Peace and Development (SZOPAD) was created in Mindanao. Particular emphasis was put on people's needs in that underdeveloped area. Reform projects were launched to promote peace, economic and social development, infrastructure, telecommunication, reconciliation between rival groups (Muslims and Christians) and, in particular, the integration of Mindanao into the Philippines (Lawphil 2021). Moreover, SPCPD did not have any law-making authority like COPAZ in El Salvador. While the presence of "non-government organizations (NGOs), and people's organizations (POs)" in the Consultative Assembly was guaranteed by the Republic Act No. 371, the OIC was excluded 
from direct cooperation for regional peace and development. Nevertheless, in its reports, the OIC kept emphasizing the significance of the provision implementation in the Autonomous Region (OIC 2006, 6).

The structure and aims of the Southern Philippines Council for Peace and Development (SPCPD) are, to some extent, similar to those of COPAZ in El Salvador and the British-Irish Inter-Governmental Conference in Northern Ireland. However, their efforts to achieve implementation were very limited. The inter-ethnic/state relationship was successfully guaranteed through the establishment of the Southern Philippines Council for Peace and Development (SPCPD) and the Special Zone of Peace and Development (SZOPAD). However, the transitional justice mechanism was not dealt with in the Agreement and the Republic Act, although 120,000 people had lost their lives in internal-armed conflicts since 1969 (Herbolzheimer 2015).

Although the executive council and the legislative assembly had not been appointed in the national executive government council as regulated in the Peace Agreement, regional legislative power was conveyed to the Autonomous Region in Muslim Mindanao (ARMM). The OIC reported (2006) that the provisions had only been partially implemented, as stipulated changes had been made by the Government unilaterally without the participation of the OIC and MNLF during the law-making process.

Governmental power-sharing was agreed upon within the framework of the Regional Autonomous Government in the peace accord which required ratification by the Government of the Republic of the Philippines (GRP). According to the Secretary-General's report on the question of Muslims in the Southern Philippines, issued by the OIC in 2006, the GRP had failed to fulfil its commitment as stipulated in the Peace Agreement, in terms of national government positions, executive council, legislative assembly and administration. It was pointed out in the report that the government's one-sided action meant "disregarding the MNLF participation as the principal party to the agreement". The agreement could therefore not be implemented (OIC 2006, 11-12). Implementation efforts varied under different presidents in the course of time. The OIC, as a pure mediator, kept urging the Philippine Government to finally overcome impediments after such a long time. The OIC did not have any leverage power. Nor did it have 
any military capacity or authorization to impose sanctions against the Republic of the Philippines.

As in El Salvador, the US would have been able to pressure the Philippine Government into achieving full implementation. However, it was reluctant to engage in mediation between two conflicting parties (Christians vs. Muslims), especially because US foreign policy was strictly directed against Muslim rebels after the 9/11 events. The OIC seemed to have not exhausted all its possibilities in terms of communication, persuasion and facilitation. In contrast, the UN undertook a major effort to achieve peace in El Salvador. It closely cooperated with multiple local actors and rival parties. In Northern Ireland, the power-sharing process was repeatedly hampered and even suspended. The British-Irish Intergovernmental Conference encouraged cooperation between both parties to resolve implementation issues, monitored the governmental development, established institutions, decommissioned arms, engendered reconciliation in Northern Ireland (CAIN 2018). The implementation process was reviewed by the commission in reports. The commission's functions were similar to those of COPAZ in El Salvador.

The parliamentary system of Northern Ireland is entirely different from the electoral system in Lebanon with its confessional segregation and guaranteed number of seats. No reciprocity problems were reported for full implementation in Northern Ireland. Sinn Fein made significant electoral gains in the second election, particularly after the Good Friday Agreement and the disarmament of the IRA. This shows that as soon as an armed conflict has been terminated, the political arms of insurgent movements stand a good chance to gain public support. Although there was dissatisfaction with the establishment of the Civic Forum (e.g., lack of gender balance, members of anti-agreement Unionist groups), the Forum started working on 9 October 2000. Its duties such as the consultation of the government on social, economic and cultural issues are stated in detail in the Good Friday Agreement, Paragraph 34 (Nolan 2012, 171). It is necessary to solve issues effectively through multi-party committees, forums, councils, groups, conferences. Systematic dealing with issues greatly facilitates implementation processes.

The transitional power-sharing government in Northern Ireland proved to be a sensible phase of implementation procedures. Two months after the signature of the Good Friday Agreement, 
the first assembly election was held in Northern Ireland on 25 June 1998. David Trimble (UUP) and Seamus Mallon (SDLP) were nominated candidates for ministerial office (Wilford 2000, 581). However, the IRA's delay in decommissioning weapons suspended the power-sharing and executive process in 2002. The issue was resolved successfully by the Independent International Commission on Decommissioning (IICD). The IICD inspectors reported that the IRA had continued to cooperate in the decommissioning process. The inspectors, Martti Ahtisaari and Cyril Ramaphosa confirmed on 30 May 2001 that the arms depot was under control (IICD 2001). After IICD's positive report, the executive power body continued to work successfully. The issue of the IRA's reluctance to decommission its arms reoccurred in 2002. The paramilitary Ulster Defence Association (UDA) equally failed to meet its obligations as to disarmament. This caused the suspension of the executive until 2007. From 2002 to 2007, the Independent Monitoring Commissions (IICD), representatives of the Republic of Ireland and the UK tried their best to resolve the issue. They met in Leeds Castle several times to work out a solution. As money was needed for the implementation process, $£ 1$ bn in financial support was provided by Ireland and the UK. On 28 July 2005, the IRA declared an "end to armed campaign" (BBC 2009). The postponement of implementation was likewise caused by disarmament problems in El Salvador. The UN successfully resolved it through intensive communication.

All in all, in the four cases the implementation of institutional-governmental power-sharing mainly depended on the quantity, dedication, expertise and full interest of multiple third parties. Although the communication and facilitation skills displayed by the pure mediators proved successful, the UN and COPAZ outperformed the OIC as the single pure mediator. The OIC was weak and not as much dedicated to the implementation process as the UN or intergovernmental third parties in Northern Ireland. The OIC and Syria did not get involved in every step of the implementation process and completely exhausted their communication and facilitation skills. The OIC did not organise any personnel on the ground or include other international organisations which could have informed them about the ongoing implementations efforts. Syria had a great deal of security forces and intelligent services in Lebanon. This shows that Syria was not engaged in any diplomatic efforts or dialogue attempts in Lebanon. The signatory Governments in the four selected cases did not equally show enthusiasm for implementation processes and peace agreements. The Philippine Government 
even went so far as to exclude the OIC, the only pure mediator, from the implementation process dealing with governmental power-sharing. Moreover, the implementation process in the Philippines had run into trouble because of changing governments. The Salvadorian government repeatedly tried to ignore third parties and the opposition. Only the strong commitment of the UN and COPAZ could overcome resistance and peace spoilers. The intergovernmental power mediators in Northern Ireland largely differed from single power mediator Syria. A group of specialists took charge of the implementation process under the leadership of the two mediators. Several trustworthy politicians, regional organisations and peace-building countries were involved in completing the implementation of institutionalgovernmental power-sharing. Although the UK and the Republic of Ireland had sufficient leverage power, they did not use it and entirely relied on experts and communication with the signatory parties. Syria, however, fully used its military power and refrained from using communication or facilitation skills. It did not appoint any experts concerning the specific implementation of power-sharing, as it fulfilled selfish political interests in Lebanon. Only multiple mediators in post-agreement societies are able to prevent such infringements in the future.

\subsubsection{Implementation of Security Power-sharing}

In El Salvador, demobilization and disarmament for security reforms were regulated in the Chapultepec Peace Accord. Demobilization of former FMLN combatants meant returning to normal life, ending armed activities, joining the newly established army and police forces which could facilitate other parts of implementation procedures. The number of regular armed forces (FAES) was reduced and its structure newly designed. FMLN fighters were ordered to return to designated locations stated in the agreement. The primary aim of demobilization was that all combatants in the country should withdraw from the conflict zones to their barracks and report in detail on the number of weapons they possessed (e.g., arms, ammunition, mines). This was to be closely monitored and verified by ONUSAL and COPAZ. Once the weapons had been handed in, they were destroyed in a scheduled timeframe (Boutros-Ghali 1995, 210-212). Implementation was slowed down because of the government's lethargic implementation effort. It was to be achieved in a parallel timeframe (ibid. 278-279). Another problem occurred 
in the land-sharing provisions in El Salvador. ONUSAL finally succeeded in solving this issue with COPAZ, jointly assisted by experts and rival parties.

Compared to the Philippines, the agreement did not contain terms such as disarmament, demobilisation or reintegration (DDR) program because MNLF members might have interpreted those terms negatively, in terms of capitulation (Makinano and Lubang 2001, 25). Articles 19.a and 20.a of the Agreement stated that 1,500 MNLF combatants in the PNP and "5,750 MNLF members" were to "be integrated into the Armed Forces of the Philippines (AFP), 250" of them were to work in auxiliary services. The recruitment area was to be in the Special Zone of Peace and Development (SZOPAD) in Mindanao. The symbolic step in matters of integration was made, when 7,000 fighters of the MNLF were integrated into the regular national army and police forces (Santos 2010, 163). Nevertheless, this was symbolically significant in terms of the cessation of hostilities. In El Salvador, the reintegration and demobilization process were more challenging due to the higher number of paramilitaries and the lack of financial resources. A parallel can be drawn to Northern Ireland, where the main issue was also decommissioning which took approximately seven years. The financing of DDR in Northern Ireland was not an issue for mediators there, compared to El Salvador and Mindanao. The number of ex-combatants in El Salvador and Mindanao was higher than in Northern Ireland, which posed even greater challenges to the third parties there. The problem of financing DDR is difficult to resolve but can be best resolved by the successful cooperation of multiple mediators.

In Northern Ireland, the demobilization issue focused on the removal of the British security forces from Northern Ireland. The removal of the troops lasted until 2007. The delay of the removal was due to the IRA's delayed decommissioning of arms. The implementation was largely successful in Northern Ireland despite numerous postponements of security questions. Demobilization was sluggish. Disarmament was a key issue before and after the signature of the Good Friday Agreement. It was stipulated in Art. 7.4 that the implementation procedures should be monitored by the Independent International Commission on Decommissioning (IICD) (Good Friday Agreement 1998). The first meeting was chaired by former Prime Minister Tony Blair and Bertie Ahern TD on 19 December 1999 (IICD 1999-2011). Several problems occurred while the decommissioning of paramilitary organizations was still going on (IRA). 
However, implementation was successfully completed due to continuous, multilateral pressure from different independent commissions, political figures and parties. The consolidation of governmental power-sharing had also provided an impetus for the implementation process.

In Lebanon, a military reform was intended in the agreement to ensure domestic security in cooperation with internal security agencies and to defend the homeland from external threats (e.g., Israel). The implementation was blocked by General Aoun. An armed conflict broke out between his forces and the Syrian army. Gen. Aoun was defeated in October 1990 (Picard and Ramsbotham 2012, 71). Syria, the power mediator, did not engage in communication, facilitation or dispute resolution. It was more interesting in a military counterattack against Gen. Aoun. A peace agreement fully including Gen. Aoun and his supporters might have avoided peace spoiling through an internal armed confrontation. In El Salvador, one of the most flagrant violations of the peace agreement occurred, when the FMLN's hidden armoury was discovered in Nicaragua. Facing this emergency issue, Boutros-Ghali and ONUSAL took initiative. The secret armoury was destroyed by FMLN and the Nicaraguan Government. The sudden discovery of the FMLN's secret arms cache proved to be the biggest obstacle for FMLN to be recognized as a political party by the Supreme Electoral Tribunal. The provision of demobilization was completed in 1995, disarmament was fully implemented in 2000 (Joshi et al. 2015). The paramilitary organizations (death squads) were found guilty of crimes against the civilian population (e.g., assassination, torture, kidnapping, genocide) (Call 2002, 574). Those crimes entailed violent fighting between guerrillas and government forces in different places of the country. The organization, structure and activity of private security were newly regulated following the principles of human rights. Implementation was difficult because the process of recovering military weapons from private individuals was deliberately slowed down by the Government. Although a great number of military weapons had been recovered, the process could not be adequately completed because of uncontrolled weapon proliferation in the past (ibid. 549). The failure of disarmament was, to some extent, due to an inadequate reintegration program, lack of funds and lack of career prospects for ex-warriors (Call 2002, 563). The Government failed to fully implement the stipulation.

El Salvador had three "security forces all of which were under the control of the Ministry of Defence" (Montgomery 1995, 168). The establishment of new police forces created a great deal 
of obstacles to military reform (Boutros-Ghali 1995, 198). The implementation was fully completed in 1997 under the watchful eyes of multiple observers. In its reports, ONUSAL kept referring to the financial shortcomings of the Salvadorian police forces, which means that money played a pivotal role in implementing the rest of the peace agreement (Boutros-Ghali 1995, 442). It was fraudulent that the government took every opportunity to employ former security officers in the newly established police forces to maintain its former power impact (ibid. 570-571). The Government's selfish strategy considerably slowed down the implementation process. Strong pressure exerted by the US and ONUSAL on the Salvadorian government largely contributed to successful implementation.

A general amnesty was proclaimed by the legislative assembly to positively influence further peace settlement efforts. After six-month research, the truth commission was able to identify who had been the perpetrator or victim (Call 2002, 575). The prisoner release process was assisted by the Salvadorian Church, local diplomats, the International Committee of the Red Cross, Amnesty International and Americas Watch (Boutros-Ghali 1995, 346). Obstacles did not occur in the implementation process of prisoner release. Lack of financial support, commitment problems and postponements of implementation decelerated the peace process. The close cooperation between the US, ONUSAL and other national actors facilitated the implementation of security reforms.

The OIC's involvement as a pure mediator in the implementation process in Mindanao was unsuccessful, as its members kept lamenting and complaining instead of acting responsibly. If the parties had implemented specific provisions in a coordinated manner and a parallel time frame, there would not have been any complaint about failing commitment. The Dispute Resolution Committee was one of the major factors to guarantee implementation safety, security and peacebuilding. COPAZ was founded to monitor implementation processes. In the event of any uncertainties and disputes, COPAZ, which was supported by the UN, took charge of finding solutions, reporting on the peace process and consulting the conflicting parties. The mandated ad-hoc commission COPAZ did not have any executive power, its function was highly inefficient (Boutros-Ghali 1995, 160). The dispute resolution committee was stipulated in the Ta'if Accords in 1989. In 1993 (Law No. 250), the independent constitutional council consisting of 10 members was established following Parliament's ratification in 2008 
(International Foundation for Electoral Systems 2009). The commission's function did not include monitoring the implementation process of the Ta'if Agreement. Its duty was merely to control the constitutionality of the laws. In Northern Ireland, the governments of the UK and the Republic of Ireland cooperated intensely to solve disputes (disarmament of the IRA). The OIC failed to solve any disputes.

The Ta'if Peace Agreement (1989) did not contain a detailed timeline for specific provisions (as in the Chapultepec peace agreement). It stipulated that the Syrian armed forces should assist the Lebanese forces over two years after the ratification. However, the withdrawal of the Syrian armed forces occurred 15 years later, in 2005. In terms of disarmament, the militias were to deliver their weapons to the Lebanese government (UN Peacemaker 1989). The implementation failed, as the militias did not keep the timeframe as stipulated in the agreement. This clearly shows the negotiators' inability to implement the agreement in a phased approach, as they did not have any comprehensive overview of the particular situation in Lebanon. The Lebanese armed forces were unable to operate as a single power for a longer time.

Hezbollah forces are still acting independently to maintain national and regional security. The provision of troop withdrawal was regulated within section C "Third, Liberating Lebanon from the Israeli Occupation" (UN Peacemaker 1989). The provision was intended to maintain full sovereignty over Lebanon's territory and its borders which had been internationally recognized. Two countries, Israel and Syria, retained a strong military presence in Lebanon. Israel had approximately 1,000 soldiers in Lebanon, whereas Syria had 30,000 to 35,000 in 1990 (CRHRP 1990, 1522). As mentioned above, the withdrawal of the Syrian army was delayed until 2005. The Ta'if Peace Agreement referred to resolution 425 of the UN Security Council which had ordered a full withdrawal of Israeli forces from Southern Lebanon, which finally occurred in 2000 (Picard and Ramsbotham 2012, 37). Due to the pressure exerted on Israel and Syria by the UN Security Council, the withdrawal of both armed forces from Lebanon finally took place. This demonstrates the UN's powerful role in successful implementation processes. It thus would be highly desirable, if implementation processes in post-conflict countries were to be conducted under the auspices of the UN. 
In Northern Ireland, the BBC (2009) documented that the IRA had finalized its decommissioning of arms on 28 July 2005. Different independent commissions were established to monitor paramilitary issues concerning the ceasefire, the decommissioning of arms, prisoner release, demobilization, and reintegration. Key measures were taken to make sure that the ceasefire and the peace agreements would not be violated by paramilitaries.

An Independent Commission on Policing for Northern Ireland was set up with experts and international representatives on policing (Patten 1999). Although the Unionists and Sein Fein initially opposed the implementation of recommendations in the first phase, the recommendations were fully implemented (2002-2007) (Joshi et al. 2015). The commission found fault with the Royal Ulster Constabulary (RUC), which had been the police force in Northern Ireland from 1922 to 1998. It criticized the inordinate employment of personnel from unionist and nationalist communities. The police reform in Northern Ireland has similarities with the police reform in El Salvador regarding proportional recruitment among rival parties, new structure and policy, form, training, education, development in terms of human rights. The UN faced the same difficulties in El Salvador, trying to prevent the employment of former loyal security government personnel in the post-agreement process. Lebanon did not have any proper national army or police forces during the implementation process. This power vacuum was filled by different armed groups and the Syrian army. In Mindanao, the OIC didn't deal with any such problems.

Pure and power mediators in the four selected cases faced various challenges in implementing security power-sharing. In Northern Ireland, power mediators were given assistance and support by different independent organisations and famous representatives of the world of politics. Disarmament, demobilization, the establishment of new security forces and the withdrawal of foreign troops required specific regulations, monitoring and financial support by third parties. In Lebanon, Syria was unable to get Israeli troops out of Southern Lebanon and implement disarmament of the paramilitary forces. The UN provided assistance to Lebanon. Israel and Syria withdraw from Lebanon after a long time. The UN also had difficulties in El Salvador, where the Government tried to keep former security officers employed in order to maintain its power. The process of bringing about a security reform was regularly monitored by the UN in cooperation with COPAZ. The Government was urged to keep its promise. At the 
same time, the guerrillas were pressured into accepting disarmament. The Nicaraguan Government provided help for disarmament procedures. In Mindanao, the OIC was too weak to put pressure on both sides. It could not persuade the parties to reach a compromise. It did not have sufficient financial funds to support or guarantee the process. It failed to establish communication between rebels and the Government in terms of security stipulations. There was not any help from the US, as the US had close relations with the Philippine Government. Their relations were even intensified after the 9/11 attacks against Muslim insurgents. In that sense, it can be said that the implementation of security power-sharing arrangements in internal postconflict countries is likely to be influenced by the international security agendas of great powers.

\subsubsection{Implementation of Human Rights and Reconciliation Arrangements}

Respect for human rights and human "dignity" is a solid basis for living together in post-conflict societies. It determines "quality peace" (Wallensteen 2015, 5). In the Chapultepec Accord, which concluded the peace process in El Salvador, human rights and the judicial system were dealt with together, as mentioned above. The human rights process had been slowed down due to a financial issue in 1992. This was a common problem that equally occurred in the implementation processes of other provisions (Boutros-Ghali 1995, 247). Although the implementation of core human rights issues had been solved, which was a positive development, many problems remained in El Salvador. The right to life and liberty was continuously violated for political motives. Moreover, physical and psychological abuse of detained persons, abductions, torture frequently occurred. All this was aggravated by an inefficient judicial system to protect the rights of individuals and a deplorable lack of criminal investigations. The lack of judges and court personnel at district courts posed an insoluble problem (ibid. 248, 254, 378). Similarly, Syrian presence in Lebanon could not prevent assassinations which likewise occurred in Mindanao and Northern Ireland. Those violations abated when peace spoilers lost their backup and peace was achieved. The signatory parties distanced themselves from violent acts. In the reports issued by ONUSAL violent crimes were considered as serious obstacles on the way to improve human rights practice according to universal standards (ibid. 574-575). What implemented the human rights provision extremely 
difficult were financial issues, frequent impunity due to the lack of investigations or court judges, vengeance committed by death squads. The "accountability for past human rights violations" has been equally identified by Call $(2002$, 563) as a major obstacle in the implementation process. Over the years, respect for human rights and fundamental freedoms has been continuously consolidated in El Salvador under the supervision of the UN and COPAZ.

Truth and reconciliation mechanisms are indispensable in the process of investigating war crimes in post-conflict societies, as they enhance accountability and ensure human rights. 22,000 complaints were filed in court after numerous crimes had been successfully investigated by a commission. Crimes had been committed mainly by security forces against civilians, especially against peasants (extrajudicial executions, death squad assassinations and torture). Judges had been killed by the FMLN between 1980 and 1991 (Boutros-Ghali 1995, 433). The commission identified most of the serious crimes. Recommendations were made as to reforming the constitution. Reconciliation was acknowledged as a core condition to prevent further crimes in the future (ibid. 434). The ad-hoc commission urgently requested President Christiani to remove former officers from office (Call 2002, 564). Defence Minister Rene Emilio Ponce and Vice-Minister General Juan Orlando Zepeda stepped down, high-ranking military officials were removed from their posts, as the most atrocious crimes had been committed in their terms of office (ibid. 564).

Besides, local human right organizations in El Salvador lacked experience in cooperating with the commission by comparison with other international human rights organizations. Moreover, the government was reluctant to provide information about criminal acts in the past. Military officers lied or withheld the truth (Buergenthal 1994, 513-515). President Cristiani granted amnesty for persons who had been involved in human rights violations (ibid. 537). In Northern Ireland, amnesty for prisoners was one of the most notable features of the ceasefire and peace agreement. Paramilitaries were released as long as they remained fully committed to the ceasefire agreement (The Sentence Review Commissioners 2008). Sinn Fein and the British government did not agree on the timing of the prisoners' release (time-varying between 1 and 3 years). Due to the personal intervention of US President Bill Clinton and Sinn Fein leader Gerry Adams, time was shortened to 1 year (Debraggio 2010, 37). The Sentence Review 
Commission was appointed by the British Parliament in July 1998 by the GFA (The Sentence Review Commissioners 2008). It was to regulate prisoner release (BBC 2015b). The agreement was fully implemented thanks to the Sentence Review Commissioners.

The truth and reconciliation processes were also critically viewed by the UN Secretary-General, who was deeply concerned about the development in El Salvador in July 1997 (UN 1997b, 7). Further challenges occurred when the truth commission was pleading with civilian victims to report crimes that had been committed during the Civil War. Victims were frightened to tell their stories, as they did not want to be exposed personally and put their loved ones at risk. Although the provision was implemented successfully (Joshi et al. 2015), this did not fully meet the expectations harboured by the commission and the victims. Moreover, local human rights organizations were not experienced enough to cooperate with the commission. Furthermore, the government granted amnesty to all individuals charged with serious acts of violence. This act is to be interpreted as a typical example of peace spoilers trying to violate the peace agreement. As ONUSAL had not anticipated the unusual step made by the Government, it utterly failed to cope with it. Such unexpected, one-sided political decisions taken by the Philippine Government frequently occurred in the Philippines. The mediators could not prevent such a decision in advance.

The Organization of the Islamic Conference (OIC) in the Philippines criticized that the educational reform lacked financial funds, that Muslims were not treated equally, as they had no access to higher education in the Southern Philippines. The OIC promised to provide financial aid (OIC 2006, 4-7). Human rights had been partly respected in the Philippines for many years. According to the Country Reports on Human Rights Practices in the Philippines (1996-2006), both parties violated human rights. Those violations were investigated by various NGOs and neutral observers. It was good that the Government allowed activists to investigate complaints of human rights violations throughout the country (CRHRP 1996-2006). However, over the years, a great number of activists were killed (Kraft 2010,187). The provision could not be properly implemented. The OIC did not carry out any activity in that context. It did not inform the UN about those human rights crimes. All in all, the provision could not be implemented (Joshi et al. 2015). The OIC activities were not identified in that regard. 
Jetschke (2011, 231-232) points out that the US global anti-terrorism policy after the 9/11 events (2001) posed a great challenge to the GRP's domestic security policy, as the Philippine Government had to find the right balance between fighting Muslim insurgents and respect for human rights in Mindanao. In that regard, ongoing peace agreement processes might be affected by the great powers' international security policy (e.g., Libya, Syria). In order to address these questions more specifically, one should ask to what extent international security trends can affect ongoing domestic peace agreement processes. Human rights had never been adequately respected in the Philippines. The OIC activities were not identified in that regard. In Northern Ireland, as everywhere else in the UK, the right stipulations are mainly agreed on in terms of basic human rights, citizenship reform, minority rights. They include education reform, official languages and symbols, reparations, right of self-determination, women's rights, independence referendum. In the wake of constitutional changes, the agreement provided the citizens of Northern Ireland with the freedom of choice between having Irish, British or both citizenships (Debraggio 2010, 46). The amendment concerning citizenship in the Constitution of the Republic of Ireland was changed on 24 June 2004 (Ward 2010, 46). In that regard, implementation resolved itself.

In the agreement, the stipulation for education is closely related to the language issue. As the UK was a contracting party in the European Charter for Regional or Minority Languages (ECRML), changes were made in the educational system of Northern Ireland in 1998 (Legislation.gov.uk 1998). The UK fulfilled its responsibilities in matters of education and language. The North/South Ministerial (Irish) Council was established on 13 December 1999 to implement language procedures. Implementation was successful. There were not any obstacles. Although the language reform had proved successful in promoting cultural diversity, sectarianism between Protestants and Catholics could not be prevented as expected (Nolan 2012, 10). The situation in Northern Ireland resembles the one in Lebanon, insofar as children go to denominational schools according to their religious faith.

Multiple challenges had to be overcome, as there are still socially explosive areas in Northern Ireland. Displacement is another serious issue in post-conflict societies. In El Salvador, 
thousands of people were internally displaced (Call 2002, 548). Their return posed a new challenge as to land ownership in conflict zones. It also affected their right to vote or to run for an office. The landowners' right to stay on their land was guaranteed in the Agreement, peasants were evicted by armed forces. Significant diplomatic efforts were pursued by the UnderSecretary-General, ONUSAL, COPAZ and equally by the government and FMLN. As they proved successful, occupation and eviction were suspended (Boutros-Ghali 1995, 242). The idea that landowners, peasants, former FMLN members and fighters should share farmlands, posed a new challenge. The land transfer programme (PTT) put the sharing of lands in disputed areas back on the right track. The implementation process continued for years, facing all kinds of bureaucratic, technical problems (UN 1997b, 1-3). The problem was solved by the UnderSecretary-General, who unflaggingly engaged in substantial talks with ONUSAL and COPAZ. The government and FMLN likewise held intensive talks. As those talks had proved successful, occupation and eviction were suspended. Farmland sharing was not an issue in other cases.

In the Salvadorian post-conflict society, mass media widely promoted the political participation of FMLN and the importance of reconciliation. They were a strong pillar of the democratic spirit of the Peace Agreement, widely supporting peace restoration, trying to prevent further political conflicts. COPAZ took charge of monitoring the process and made new suggestions. At the same time, ONUSAL verified the implementation process (Boutros-Ghali 1995, 218). It was found out in 1994 that the ARENA and the Convergencia Democratica had violated Article 18 which regulated the rules of electoral propaganda. ONUSAL cooperated with the Supreme Electoral Tribunal to cope with complaints effectively (ibid. 529). In Lebanon, human right reforms against discrimination were also established. Development, reconstruction and reconciliation in the educational system were agreed upon for schools and universities (UN Peacemaker 1989). The spirit of the Ta'if Accords aimed at the abolishment of sectarianism and confessionalism. Nevertheless, it was noted in the Report on Human Rights Practices that private Lebanese schools propagated confessional discrimination (CRHRP 1989, 1773; CRHRP 1992, 1048). Social inequality was not diminished by the Government and third-party Syria. The UN was unable to help financially due to a lack of funds (CRHRP 1995). As a result, the provision could not be fully implemented (Joshi et al. 2015). Syria had never pressured the Lebanese Government into improving the human rights situation in Lebanon. Lebanon is facing an enormous challenge, as lots of its people were internally and externally displaced due to 
numerous cruel intra-state conflicts. Moreover, it has had to come to grips with the Palestinian refugee question since the outbreak of the first Arab-Israeli war in 1948 (Picard and Ramsbotham 2012, 100). Unfortunately, human rights could not be entirely implemented (Joshi et al. 2015). As Lebanon was a small country based on multi-ethnic and multi-religious principles, the complete naturalization of Palestinian refugees constituted a challenge to the confessional balance in Lebanon (CRHRP 1989, 1474-1975).

As the Lebanese mass media emphatically voiced the specific political attitudes of the conflicting parties in Lebanon, access to printed media of rival parties was deliberately hampered in areas dominated by one major party (CRHRP 1989, 1473). Although some bills were submitted in Parliament, the human rights provision could not be implemented as required. Pressure from Syria was not identified in the implementation process. Syria neither documented the complaints in detail nor did it communicate with the parties to implement human right stipulations. As long as Syria's military and political interests were not affected by the conflicting parties, Syria did not do anything to support any rights implementation. In El Salvador, ONUSAL documented complaints in detail and communicated intensely with the parties to solve problems in terms of rights implementation.

In the Philippines, essential human right issues were regulated such as crimes against humanity, discrimination, cultural protection, education reform, official language and symbols. Article 103 of the Peace Agreement emphasized the following aspects in education: protection of cultural diversity, languages, values and traditions, history of Muslims, Christians and indigenous societies. Those educational goals were similar to the ones in Lebanon and Northern Ireland. In Mindanao, the educational system could not promote the kind of unity and reconciliation between rival societies as desired. Although the educational reform proclaimed freedom of language at schools in the autonomous region, discrimination of minority languages in favour of national (official) languages has been an ongoing issue (May 2012; Karakus 2015b). The urgently required reforms in the Philippines were carried out following the Republic Act 9195 and DepED Order No. 51. The implementation efforts made by multiple third parties in Northern Ireland outperformed the OIC in Mindanao and Syria in Lebanon. Anti-discrimination human rights arrangements were taken more seriously in Northern Ireland to prevent future clashes. 
The Good Friday agreement dealt with the reparation issue. According to an investigation conducted in 2016, the number of troubles related deaths had risen to "3,649" (Potter and Campbell 2014, 16). The Peace III Program (2007-2013) allocated nearly 37 million pounds in support to organizations that offer care to survivors of domestic violence (ibid. 2). However, reparation does not only refer to financial or material recovery. In Northern Ireland, no truth commission would help traumatized victims, prevent future conflicts or facilitate reconciliation between post-conflict communities.

In terms of human rights reforms, the four cases addressed some core issues in their respective peace agreements. Pure and power mediators performed differently to enhance implementation. Multiple pure and power mediators in El Salvador and Northern Ireland outperformed single mediators such as Syria in Lebanon and the OIC in Mindanao. Multiple third parties worked closely together with human right experts and different independent groups. They regularly noted missing implementations and exerted pressure on parties to complete implementations. The activities of the two single mediators were inefficient. Syria's low level of implementation effort, the OIC's inability to persuade the conflicting parties to seek a compromise. International Human Rights organizations made a tremendous effort to identify the lack of human rights. Unfortunately, numerous volunteers working for human rights organizations lost their lives in their fieldwork.

\subsubsection{Implementation of Economic Power-Sharing}

In El Salvador, implementations in terms of economic and social development continuously faced delays and postponements. A contractual commitment should be measured by the conflicting parties' compliance with the set schedule of implementation. In the agreement, the schedule was very detailed, comprising specific steps to be done on specific days. However, details as to certain provisions had not been clearly worked out by third parties, e.g., the specification of conflict zones, land redistribution to peasants and reconstruction. Considerable delays occurred after the discovery of secret FMLN weapons in Nicaragua and after armed forces had forcibly occupied the land of farmers. Those delays occurred in different periods. 
Problems of timetable and uncertainty were solved, with the help of ONUSAL's communication and monitoring skills (Boutros-Ghali 1995, 598). Delays and commitment problems caused by both sides hampered the process. They were gradually removed in the course of the mediation process. This was largely achieved through advice, pressure, technical assistance and financial funds provided by the UN (ONUSAL) and COPAZ. Studemeister (2001, 40) argues that "institution-building is a slow process". Financial issues as to reconstruction and reconciliation are a common problem in post-conflict societies (BoutrosGhali 1995, 50). Donor countries, international and regional institutions (The World Bank, IMF, Inter-American Development Bank, the US) took great interest in financing the process with certain preferences (ibid. 44-45). Preference issues were resolved without too much delay, with the help of the UN and donor countries. Resolving those problems strongly facilitated further implementations.

The need for technical help was also fully met. The agrarian issue, one of the main causes of the Salvadorian Civil War, was a serious problem in the post-war implementation process. It constituted a key factor for economic and social development in the post-conflict period. The government established a "National Reconstruction Plan" for sharing lands between former warriors (Boutros-Ghali 1995, 29). Moreover, a "Forum for economic and social" development was created in which the government and "labour and business sectors" worked together to find answers to land issues (ibid. 161). A problem occurred again as to the actual residents of lands in conflict zones. The security forces evicted the peasants from some areas, as they wished to occupy these lands themselves. COPAZ and ONUSAL mediated between peasants and the Government, trying to find a solution but eventually failed. Secretary-General Boutros-Ghali personally intervened on October 13, 1992, urging President Christiani to fulfil his commitments regarding land transfers (ibid. 256). Completing further implementation in that regard, Kofi Annan cooperated with the UNDP and donor governments (UN 1998, 2). The provision was fully implemented thanks to intensive diplomatic efforts (1997-1998) (Joshi et al. 2015). In Lebanon, one provision was to be dealt with in terms of economic and social development (UN Peacemaker 1989). Although Lebanon urgently required proper reconciliation and reconstruction, the council that was to solve this problem had not been established in Parliament yet. Syria did not provide any substantial, external support during the 
first 10 years of the implementation period, which could have facilitated the implementation process to a great extent, as in El Salvador and Northern Ireland.

In the Philippines, the OIC and other parties were to review the implementation of Economic and Social Development. The OIC issued only a few reports which were considered inadequate by the Government. Its first general and comprehensive review occurred 10 years after the signature of the Agreement. Although the Government had passed Republic Acts in favour of Mindanao autonomy, SZOPAD and SPCDP, the OIC $(2006,11)$ heavily criticized the National Government's strategy of ratification, as the government had been acting autocratically, ignoring critical opinions. The OIC as a single third party was too inactive, failing to provide an incentive to the government. The implementation process was repeatedly postponed. This was due to several reasons: ceasefire violations, financial shortcomings, constitutional reviews, exclusion of conflicting parties, timing incompatibilities as to referendums and national elections. The OIC and other external actors failed to accelerate proceedings. As mentioned before, delays always constitute a risk, as the agreement might be violated by "spoilers". In the Philippines, this risk was emphasized by Dr. Danda Juanday, a member of the board of the Bangsamoro Development Council and executive director of the Bangsamoro Development Agency (Ampatuan et al. 2010, 40).

Article 12 of the Peace Agreement stated that OIC assistance was needed to finance the implementation process. In the framework of the Autonomous Region in Muslim Mindanao, the Southern Philippines Council for Peace and Development (SPCPD) was created by Republic Act Order No. 371 in 1996. The Special Zone of Peace and Development (SZOPAD) was established in 2001, which received international financial support (The World Bank 2002). The OIC reported that the Philippine National Government was providing a limited amount for the "infrastructure and other government programs" in Mindanao (OIC 2006, 8). The OIC blamed the National Government's discrimination policy and unfair distribution of wealth, as, in its view, the government-controlled the "natural resources in the Muslim areas" and was responsible for the underdeveloped conditions in Mindanao (OIC 2006, 6). The Philippines Country Report on Human Rights Practices (1997) reported that Nur Misuari had been complaining about the lack of government support for Mindanao (CRHRP 1998). CRHRP 
(2006) estimated that there was a high level of poverty in Mindanao. The OIC strongly criticized the government's one-sided decision on strategic mineral regulation, blaming the government for having violated the Peace Agreement (OIC 2006, 9) The regional recovery of the economy was not as effective as expected. The provision was not implemented as desired. Although the OIC complained about the failed implementation, it remained inactive for the most part.

In Northern Ireland, the Good Friday Agreement took account of the economic and social development of the divided society. A special commission was established to implement necessary changes, especially as to discrimination and equal chances in employment (Obe and Obe 1998). The implementation of economic and social development was regularly reviewed, verified and monitored by officials from the UK, the Republic of Ireland and Northern Ireland. They were assisted by several national, international and independent commissions and mixed councils. They issued reports to the parties, instructing them on how to reform and implement disarmament and policing, on how to combat discrimination and unemployment. The most important steps in the Peace Agreement Process were the ratifications in the Republic of Ireland, Northern Ireland and the British Parliament, which were mostly implemented on schedule. In contrast, the decommissioning process of arms was deliberately delayed by the IRA and other paramilitary groups. Although delays in the implementation of some provisions had occurred, all the provisions were implemented according to the set schedule (Joshi et al. 2015).

In sum, multiple pure mediators such as the UN and COPAZ in El Salvador faced several commitment problems in terms of economic power-sharing. Secretary-General Boutros Boutros-Ghali personally intervened to enhance implementation. As he needed money for the implementation process, he organized donor support from different countries, international and regional institutions for the implementation process. In contrast, the other single pure mediator, the OIC, was simply too inactive, failing to impact positively on the Government in a sustainable manner. It strongly rejected the Government's discriminatory attitude and the unequal socio-economic power-sharing with Muslim areas. It also criticized the Government's one-sided decision on strategic mineral regulation. However, it should have intensely 
communicated with the Philippine Government in the way the UN did in El Salvador. Power mediators in Northern Ireland cooperated and communicated very closely with other independent councils and conflicting parties and thus achieved successful implementation. In Lebanon, however, substantial, external economic support was lacking during the first ten years of the implementation period. Syria proudly relied on its military power. It did not improve the socio-economic conditions there. International financial support was also lacking. Multiple mediators such as France, Saudi Arabia, Egypt or the EU could have financially supported the economy in Lebanon. 
Chapter VI Conclusions:

Academic and Practical Implications 
In order to assess the impact of international mediators on the implementation of peace agreements, this dissertation has been guided by the following research question: Under what conditions can external (pure and power) mediators enhance the implementation of mediated intrastate peace agreements? Based on empirical analysis, some general and specific results are identified in terms of the present-day international mediation theory, implementation research and sustainable peace. I have reached the central conclusion that multiple power or pure type third-party mediation is crucial to enhance a proper implementation of peace agreements in the long-term. By contrast, single pure or single power mediators are less likely to ensure implementation as shown in the comparative analysis and single case analysis of El Salvador, Northern Ireland, Lebanon and Mindanao. This result also confirms my hypothesis: If multiple mediators (pure or power) support a peace implementation process, they are by far more successful than singly acting mediators. How does this relate to previous research in mediation strategy? As to previous research on conflict resolution, Svensson (2007) argues that an alliance of pure and power mediators is more successful in reaching power-sharing agreements than the action of a one type of mediator. His findings are aimed for short-term mediation in terms of conflict resolution. My findings, however, are not based on a pure+power combination, but rather on one type of pure+pure or power+power combination. This will enable future research to focus on the impact of pure+power combination on implementation. The common point of the two different arguments is that multiple mediators exert a positive influence on peacebuilding. Vuković $(2015,66)$ supports this theory, pointing out that multiple mediation efforts of neighbouring states were successful in Tajikistan. However, the role of multiple mediation as a success factor largely differs from single mediation supported by Beardsley (2011), who argues that long-term mediation might fail due to lack of coordination between multiple mediators.

When the Good Friday Agreement was implemented in Northern Ireland, the most important associations providing multiple mediation were the British-Irish Intergovernmental Conference, the North-South Ministerial Council, the Independent International Commission on Decommissioning supported by the Equality Commission and the Independent Commission on Policing in Northern Ireland. They were firmly established associations, supported by the UK and the Republic of Ireland, as those two countries were considered to be the guarantors of a long-term implementation process. Due to the enormous peace efforts of these mediators, 
successful implementation was achieved. The most urgent core incompatibilities, such as disarmament paramilitary groups and reforming police forces were solved by the Independent International Commission on Decommissioning and the Independent Commission on Policing in Northern Ireland. External, independent, international or regional organisations and NGOs were required to implement provisions such as transitional justice, reconciliation, DDR processes and elections. Such organisations were technically advanced in specific issues. Implementation conducted under the leadership of multiple mediators resulted in more success. Their success was largely due to their cooperation with the rival parties in Northern Ireland. They created independent, international and national commissions, aspired for lasting peace, committed themselves to the prevention of recurrence conflict, emphasized the inclusion of all social strata and claimed financial support for peace.

One can conclude from the post-agreement conditions in Lebanon, El Salvador and Northern Ireland that two or more external parties give proper balance power and confidence to rival parties supporting the implementation process. Nathan (1999) also suggests enhancing confidence-building between rival parties and discourages the use of power/leverage for longterm peacebuilding. Syria, the single guarantor or protection provider in Lebanon, provided only partial implementation, as it was mainly interested in its own national benefit in a onesided manner. Had France been involved as a third party in Lebanon together with Syria, the two powers could have reached a proper balance between the rival parties and could have more adequately satisfied the demands of the Maronite Christians. The participation of an international or regional party such as the UN could have put the process on the right track.

The main objectives of external mediators are to ensure successful implementation of ceasefire arrangements, institutional-governmental power-sharing, security power-sharing, economic power-sharing, respect of human rights and reconciliation arrangements. However, there are also situational factors promoting or hampering the efforts of mediators to implement peace agreements: varying difficulty of implementing provisions, commitment problems of parties in the implementation process, peace spoilers, financial situation of post-conflict countries as to funding peace and security, design of peace agreements to avoid misinterpretations in the implementation period, the challenge of early-stage implementation and occasionally US agenda for international security. This means successful implementation does not only depend 
on the skills and efforts of long-term mediators. Situational factors should also be taken into account in implementation processes. Coping with all those challenges is the ultimate task for multiple mediators.

My second conclusion is that different aspects of provisions have been dealt with as steps towards implementation. Certain stipulations in the four cases were more difficult to implement than others. The most challenging provisions to implement were related to the core incompatibilities which led to intrastate conflicts in all four cases. The conflicting parties primarily insisted that their demands be implemented first. Claims were made as to new elections, constitution reforms for autonomy, equal opportunity for election campaigns, security issues such as a ceasefire, disarmament, demobilization, reintegration of former rebels and security forces, prevention of peace spoilers, justice issues such as law-making for democratic institutions, transitional justice, reconciliation, a merit-based system for appointment of the heads in the executive instead of ethnic, religion-oriented nepotism, economic issues such as equality and social justice, equal distribution of farmland. The implementation of certain provisions required proper technical and scientific assistance from third parties such as farmland redistribution or the disarmament of rebels. Skilful mediators having detailed knowledge of the root causes of the conflict and being fully aware of what was at stake, devoted their energy to achieve successful implementation. Without their expertise, provisions could not have been adequately implemented, as stipulations might have been incorrectly interpreted by rival parties for their own benefit, which was the case in El Salvador, Lebanon and Mindanao. Therefore, the formulation of stipulations should be as clear as possible to avoid misinterpretations. Mattes and Savun $(2010,511)$ also point out that the proper design of agreements is crucial to prevent civil war recurrence.

As shown in the case analysis, Syria, the power mediator, was more successful in Lebanon than the OIC (pure mediator). It enhanced the implementation of ceasefire arrangements and internal security. The prevention of armed confrontation between rival parties was achieved by putting military enforcement, by providing security and recruiting personnel on the ground. That means a single power mediator can outperform a single pure mediator to implement ceasefires and military/security arrangements. This idea is closely linked to Svensson's concept of power mediators: "Power mediators are particularly suitable for reaching agreements where the military power is regulated" $(2007,231)$. This seems to be applicable to short-term mediation 
and conflict resolution. However, it focuses on the presence of a security guarantee which may encourage the longevity of peace agreements (Svenson 2009; Walter 2002). A security guarantee was properly provided in the Lebanon case, but not in Mindanao.

My third conclusion is that commitment problems frequently occurred in the implementation period. Whenever some implementation was postponed, there were mutual recriminations, with each party accusing the other of having started the trouble. This could have been avoided if both sides had been seriously committed to an implementation process supervised by multiple mediators appealing to both sides in parallel timeframes. The implementation of the following provisions proved a difficult task: demobilization-disarmament-reintegration, farmland sharing, organising elections and referendums, ceasefire, transitional justice, confidence building. Technical assistance and financial support were strongly needed. In search of a comprehensive solution, independent experts should be consulted by mediators. The comparative case analysis reveals that commitment problems can be solved by building up trust between mediators and rival parties. Single mediators might not be up to the task, as they might misuse their actions for their own profit. Multiple mediators are better at solving commitment problems, as a peaceful settlement of a dispute and the well-being of a country is their ultimate goal. A strong commitment was an indispensable prerequisite for the implementation of the peace agreement in Northern Ireland. It was impressively demonstrated by Unionists and Republicans in the Northern Ireland peace implementation process. Power-sharing and human rights which people had longed for, were finally guaranteed by referendum and ratified by Parliament. External technical and financial support was provided by the EU, the UN, the US and several other countries before and after the signature of the agreement. The fact that the UK and the Republic of Ireland were responsible members of the EU and European organizations such as the European Charter for Regional or Minority Languages (ECRML), the European Convention on Human Rights (ECHR), provided a great deal of impetus to the implementation process in Northern Ireland. The decommissioning of IRA arms and other paramilitary arms was a serious challenge. The problem of the suspension of the executive was solved by the British-Irish Council and the Independent International Commission on Decommissioning. Decommissioning was guaranteed by Prime Minister Tony Blair. Other unresolved issues were addressed by Gerry Adams (leader of Sinn Fein) and US President Bill Clinton. In El Salvador, delays and commitment problems caused by both sides hampered the 
peace process. They were gradually removed in the course of the mediation process. This was largely achieved through advice, pressure, technical assistance and financial funds provided by the UN (ONUSAL) and COPAZ.

The following peace-supporting activities performed by mediators greatly helped to reduce commitment problems: 1. technical assistance and advice, 2. financial/donor support for implementation, 3. confidence building, 4. personal guarantees given by credible leaders (Prime Minister Tony Blair, Bill Clinton, Gerry Adams, UN Secretaries). Peace-supporting activities should always be performed by multiple mediators jointly and not by single mediators to avoid undue benefit for single mediators in the country concerned. The above-mentioned peacesupporting activities complement each other, building on the idea that a third-party security guarantee is crucial for long-term peace (Walter 2002, DeRouen and Chowdhury 2013). At the same time, mediators perform verification and monitoring tasks more adequately than single mediators in the field, as multiple mediators are supported by expert groups. Whenever these tasks are performed inadequately, one can tell right away which side does not fulfil its implementation promise properly. Once commitment problems have been identified, mediators are asked to increase leverage. This finding is consistent with the concept of verification mechanisms to overcome commitment problems (Mattes and Savun 2010, 9).

My fourth conclusion is that peace spoilers regularly tried to violate implementation processes. They were rigorously kept under control and eliminated by multiple mediators. They emerged as excluded parties or splinter groups opposing the peace agreement. They also affected the signatories of peace agreements (government and rebel sides) and singly acting third parties. The most striking examples of peace spoilers seriously impeding implementation processes were identified in El Salvador (rebels' secret arms cache, governmental recruitment plan) and Northern Ireland (IRA's withdrawal from the decommissioning process) and Syria (initiating a military struggle led by a former general). The Philippine Government reneged on its promise, refusing to fulfil the requirements related to the implementation. It had passed new laws (Republic Acts) which were incompatible with the spirit of the peace agreement and even had the chairman of the rival party (MNLF) arrested. As governments frequently changed in the Philippines (2001-2010), it so happened that the new government did not approve of the current peace agreement and simply suspended it. Peace spoilers should therefore be carefully monitored by multiple third parties, which did not occur very often in the past. If the UN had 
intervened in war-torn Lebanon, it might have been able to keep the warring parties and the single mediators' self-interest under control. Lack of leverage power and weak capacity displayed by third parties encouraged peace spoilers to violate implementation processes. In three cases of my comparative analysis, peace spoilers were the parties themselves and in one case (Lebanon) a former army general acted as peace spoiler, as he vehemently opposed peace agreements. My finding is that a strategic cooperation of multiple mediators can more easily prevent peace spoilers and facilitate implementation than a single mediator, as they have multiple communication channels with locals, monitoring and verification capacities on the spot. They are more able to identify peace spoiling strategies. In the Syrian case, where there was a single third-party, military power was successfully used to prevent peace spoilers. The Syrian military success confirms Call's theory (2012) that the presence of third-party military troops maintains stability and helps to build up sustainable peace. All in all, peace spoiler prevention largely contributes to implementation success. The concept of sustainable peace as expressed in my analysis is consistent with the findings of Stedman (1997, 2002) and Bercovitch and Simpson (2010).

My fifth conclusion is that external financial support for implementation is very important. My research reveals that post-agreement societies were exhausted after a long history of internal conflicts. They were economically weak. Their political and governmental conditions were shattered, security was poor. Rival parties tried to obtain financial support for the reconstruction of their country. I maintain that a cooperation of multiple mediators can cope more easily with the financial challenges of post-agreement societies. It has various financial capacities, networks and connections with other countries and donors, regional and international actors. External financial support was provided in a satisfactory manner in El Salvador and Northern Ireland and but not in Lebanon and Mindanao. State capacity and the strong economy of a postconflict country are significant requirements to support peace implementation and lasting peace. Similar conclusions have been reached by Sobek (2010), Stedman (2002) and DeRouen et al. (2010).

My sixth conclusion is about UN involvement in the implementation process in El Salvador, where the ONUSAL acted as an external mediator, closely cooperating with COPAZ in a successful peace-building process. Power-sharing in terms of government, security and economy was successfully established there through fruitful cooperation. The implementation 
process was stepwise realized under the clear leadership of the ONUSAL. It largely contributed to the successful implementation of a peace agreement achieving 96\% of implementation (Joshi et al. 2015). The ONUSAL cooperated closely with civil societies and other parties at national and local levels. National actors were likewise coordinated by the UN. The UN's successful involvement in the Chapultepec Peace Agreement avoided possible misunderstanding and prevented conflict recurrence. Its brilliant negotiation skills were demonstrated in previous peace-talk attempts between the Salvadorian Government and the guerrillas. The peace negotiations in the four selected cases demonstrate that long-term mediators should have a solid knowledge of the core causes of the conflict before and after signing peace agreements. They should also possess excellent communication and cooperation skills. They should have strong leverage power and convincingly provide power-sharing mechanisms in implementation processes. Moreover, they should be technically trained and be provided with legal expertise and support. All those different aspects are reflected in the successful Northern Irish Peace Agreement and the Chapultepec Peace Agreement in El Salvador. The UN had strongly cooperated with COPAZ, FMLN and the Salvadorian Government. In that regard, the UN's pure mediation efforts were highly beneficial to the long-term implementation process. This result is in line with the views of Arnault (2006), Joshi and Darby (2013) and Stedman (2002). It shows that the UN is capable of facilitating implementation processes. Single external longterm mediation would have definitely failed in El Salvador.

In El Salvador, the UN continuously held bilateral meetings with the leaders of the two parties, various actors and commissions during the implementation process at national and local levels. The Secretary-General repeatedly pleaded with both parties to adhere to their commitment. The UN consciously took care of every step in the implementation process, as it was regularly informed by UN bodies about possible obstacles. It applied leverage on both parties to facilitate implementation. The US equally put pressure on the Salvadorian government. As new technical issues emerged, expert commissions were created which provided help. A pivotal factor facilitating the implementation process in El Salvador was financial support for the promotion of democratic institutions and the reintegration of ex-combatants. Lack of financial support would have undoubtedly shattered Kofi Annan's peace efforts.

The UN acted jointly with the Salvadorian government, the Salvadorian church, local diplomats, the International Committee of the Red Cross, Amnesty International and Americas 182 
Watch to grant amnesty to former FMLN members. The Salvadorian government established a new legal basis for their equal political participation in future elections which guaranteed the political inclusion of former rebels. Political inclusion supported lasting peace. This confirms Call's theory (2012) that the integration of former enemies into political or security institutions closely corresponds to successful peacebuilding in the Post-Cold War era and peace consolidation. Governmental power-sharing is considered by peace researchers to be one of the main factors securing sustainable peace. As required by the Salvadorian government, the UN established a monitoring mechanism for the national elections. Unexpected challenges occurred, when the FMLN's secret arms cache was detected and the government granted a general amnesty to criminals from both sides (assassins, death squads, illegal organisations). This meant that UN peace-making efforts in El Salvador had been completely ignored. It also meant that former death squads would be forgiven or that they would be even "awarded" for their atrocities. Assassinations of high-ranking persons are considered devastating peace spoilers, as they can even terminate peace processes.

The Salvadorian government and FMLN had never jointly asked a single third party for mediation or negotiations, except for the UN. The UN enjoyed greater trust than any other national actors in the country, so almost all previous negotiations were conducted by the UN. The opposing parties had high hopes, as the UN was highly thought of internationally. It was considered an unbiased and influential third party. Besides, the UN had signalled interest in the peace settlement in El Salvador, which was not always the case in armed conflicts. The Roman Catholic Church in El Salvador also aspired for peace, trying to mediate between the opposing parties. When Archbishop Romero was assassinated by a rightist paramilitary (1980), the Church did not lose hope. It successfully organized a prisoners' exchange between the Government and guerrillas. Although the Church's strenuous peace efforts did not lead to any direct peace agreement, it certainly paved the way for further peace talks (Chavez 1984).

Several problems remained unsolved for many years in El Salvador: abuse of detainees, abductions, torture, the inefficient judicial system and court personnel, lack of investigation, failing accountability for past human rights violations, especially in farmland. Those issues were gradually resolved by the UN in cooperation with COPAZ and Salvadorian key actors. Furthermore, Boutros-Boutros Ghali and Kofi Annan (former UN Secretary-Generals) engaged 
in tough, short and long-term mediation efforts before and after the signature of the peace agreement. The UN's long-term mediation success in El Salvador might be considered as an excellent example of future peace agreement implementation cases in other post-agreement societies. The idea of the UN's positive effect on peace agreements is taken up by Stedman (2002, 110), who recommends involving UN authorities for implementation success.

My seventh conclusion is that US international security policy has a twofold effect on peacebuilding processes. The US international security agenda (struggle against Communism) after the end of the Cold War had a positive impact on the peace process in El Salvador. On the one hand, the US played a decisive role, as it softened its anti-communist guerrilla policy in El Salvador. The newly unbiased US foreign policy in El Salvador also caused the Salvadorian government to be trapped in a stalemate position, which forced the rival conflicting parties to launch peace talks. On the other hand, the US international security agenda after 9/11 affected the peace process in Mindanao, as it strongly targeted Islamists fighting against the government of the Philippines during the implementation process, which implies that the ongoing US international security policy could overlap with the implementation of other peace processes.

Syria is classified as a power mediator type, responsible for Lebanon's internal security and peace. It provided governmental power-sharing to the conflicting parties. It directly interfered in Lebanon's internal affairs due to the bilateral „Agreement of Brotherhood” (1991). It officially justified its interference in Lebanon's domestic policy by stating that its presence in Lebanon was to build up peace there. However, it mainly acted for its own political benefit. As the rival parties belonged to different religions (Muslims versus Christians), Syrian interference was given full support by the Muslim parties in parliament, whereas the Christian Maronites were strongly opposed to Syrian interference in Lebanon. This caused a recurrence of internal armed conflicts. The presence of an additional unbiased country would have probably increased the chances of implementation success. The presence of the UN as a non-denominational, international agent would have been highly beneficial there, as the UN is neutral and entirely focuses on its core mission of peacekeeping. 
In terms of strategic coordination, Syria didn't cooperate with any other international organizations such as the UN, Amnesty International or Human Rights Watch. It failed to build a national monitoring committee such as COPAZ in El Salvador or the Independent Monitoring Commissions (IICD) in Northern Ireland, involving all the members of the rival parties. This was mainly due to its weak communication and facilitation capacities, its inability to deal with the rival parties' commitment problems and their postponement of implementations at local and national levels. Syria's exclusionary attitude as a third party proved its one-sided political interest in Lebanon. Although most of the governmental power-sharing was guaranteed in the constitution in terms of seats, number and governmental representation, several provisions were neglected and not implemented. Any exclusion of Maronite Christians in governmental powersharing in parliament might have caused another internal conflict if their participation had not been guaranteed. In Lebanon, there is another open question: the huge number of Syrian refugees, who are mainly Sunni. One day this demographic change might require a new constitutional constellation which should be dealt with soon, before another conflict reoccurs.

Several situational factors in politics, economy and security were identified in the postagreement period in Lebanon. The most positive results of the Ta' if Peace Agreement were the prevention of a recurrent armed conflict and divided governmental power-sharing between the different religious groups, guaranteed in the Lebanese Constitution. "External factors are paramount in explaining the varying degrees to which power-sharing regimes have succeeded at maintaining domestic peace in Lebanon." (Zahar 2005, 232). Syria's strong military presence had difficulties in preventing the military revolt of Army Commander General Michel Awn, who had used his military power to block governmental power-sharing in the Lebanese Constitution to secure Maronite privileges. The ties between Syria and Lebanon are still very close, especially because of Hezbollah, the regional power struggle between Iran, Saudi Arabia and Israel and the ongoing Syrian Civil War.

My eighth conclusion is about reconciliation. The integration of different religious groups which aimed at preventing sectarianism, confessional segregation and the discrimination of non-Lebanese residents such as Palestinian refugees, proved unsuccessful. Frequent assassinations and human rights crimes are still serious problems in the post-conflict period. Rigid, political sectarianism has impeded reconciliation in Lebanon. The high quality of 
democracy seems to remain fragile. The lack of reconciliation is still a problem in Northern Ireland. Future research should comprise a comparative case analysis of post-agreement societies such as Northern Ireland and Lebanon. One could then find out to what extent the peaceful coexistence of rival communities (religions) has been facilitated after the signature of the peace agreements of each of the two countries. As there was no truth commission in Northern Ireland, traumatized victims found it difficult to come to terms with their past. Reconciliation between post-conflict communities has been constantly hampered. The transitional justice mechanism was not dealt with in Mindanao. 120,000 people lost their lives due to internal armed conflicts. Transitional justice committees did not exist in Lebanon, Northern Ireland and the Philippines. There was one in El Salvador, which operated inadequately.

Arabic news coverage on the Lebanese peace implementation process should be enhanced by researching local news after 1989. Moreover, officials who were in charge of the implementation process should be interviewed to gain a closer knowledge of the implementation circumstances. It is difficult to research sources to assess Syria's long-term role in the post-conflict period, as official reports of the Syrian and Lebanese governments were sporadic and academic research on the implementation process of the peace agreement has been limited.

The European Union could provide long-term mediation in Northern Ireland. However, the peace talks might be likely to fail as long as the two guarantor bordering countries, the UK and the Republic of Ireland, did not agree on the content of the peace agreement for fear of jeopardizing their political interests in Northern Ireland. In that case, unbiased UN mediation is more likely to occur rather than EU mediation to achieve a long-term peace-agreement implementation. In the case of Northern Ireland, technical expertise was regularly provided to keep the implementation process going. As the British and the Republic of Ireland were contracting parties in the GFA, they also acted as mediators between Protestants and Catholics. Whenever the implementation process was impeded, Tony Blair (UK), US President Bill Clinton and Sinn Fein leader Gerry Adams launched painstaking initiatives. The delay of the implementation of one provision sometimes caused the delay of another, as the provisions were 
strongly linked with one another. Parallel implementation of provisions between rival parties is highly recommended to avoid mutual accusations, condemnations and commitment problems.

In the long run, the consequences of Brexit might affect Northern Ireland's economic, social and foreign affairs with the EU. They might even jeopardize the social integration process of Unionists and Republicans. Although people in Northern Ireland voted in favour of remaining in the EU by "440,707" votes against " 349,442 ", this was a narrow majority (The Electoral Commission 2018). The relations between Unionists and the British Government are also a matter of concern. The future of Northern Ireland remains insecure. Article 3 of the Good Friday Agreement states a possible future unification of Ireland. So, the people of Northern Ireland will be allowed to decide about their future along with the people of the Republic of Ireland. This particular jurisdiction and the consequences of Brexit will be an important issue in the future. There may be another referendum ahead. People might then vote in favour of a United Ireland. Future analytical research into the Northern Ireland peace framework would be instructive, particularly in the framework of Brexit. It would be interesting to know what effect Brexit will have on the Good Friday Agreement.

In the case of the Philippines, articles 12 and 13 of the Mindanao Final Agreement (MFA) gave authority to the Organization of Islamic Conference (OIC) as the third party assisting, to guarantee and monitor the implementation process. It can be concluded that the OIC was less likely to achieve successful peace-agreement implementation in Mindanao compared to Northern Ireland and El Salvador. The main obstacle to implementation was that the government acted in a one-sided manner by releasing the Republic Acts (commitment problems) and systematically disregarded the OIC in the implementation process. In contrast, the OIC was less interested in communication and facilitation work, too weak to put pressure on the government. However, it operated successfully as a short-term mediator in agreements as to negotiations, ceasefire and peace. Nur Misuari, the founder of the MNLF argued that "the talks and the agreement would have been impossible without the OIC because the MNLF was determined for sovereignty“ (Stankovitch 1999, 76). A strong monitoring and verification mechanism would give strength for implementation. Another conditional challenge was that the OIC did not have any peacekeeping military personnel and civil experts in the post-conflict area, so they were unable to provide monitoring in the field and secure the implementation 
process. Moreover, the agreement did not specifically provide a DDR program aiming at the complete disarmament of MNLF fighters, as the availability of arms would have caused violation (Özerdem 2012, 406). There was hardly any cooperation between the OIC and the government. The parties were not supposed to regularly inform the OIC about their implementation efforts. In contrast, they were supposed to inform COPAZ in El Salvador. The strong involvement of peacekeeping forces for peacebuilding implementation is an important component for sustainable peace. This argument is in the line with research findings of Arnault (2006), Joshi and Darby (2013) and DeRouen and Chowdhury (2018).

Although the peace agreement did not fail, the implementation of Mindanao Final Agreement scored as low as 59\% (Joshi et al. 2015). It would have been possible to involve countries such as the US, Malaysia or Australia as third parties, or the UN or ASEAN. They could have pressured the Philippine government into overcoming its commitment problems. The US as the strongest military power could have done a good job, the way it did in El Salvador, when the implementation process had reached an impasse. As US international security policy strongly targeted Muslim insurgents after the 9/11 events, the US was not suitable for the mediation task in Mindanao. Incidentally, the implementation of the agreement was almost brought to a standstill, when joint military operations against other rebel parties in Mindanao which had been excluded from the Mindanao Agreement, seriously impaired the ongoing peace process. In that regard, ASEAN would have been a good, powerful actor. Although it was not directly involved in the Mindanao peace process, the ASEAN Charter states that the main purpose of ASEAN is "to maintain and enhance peace, security and stability and further strengthen peaceoriented values in the region" (The Association of Southeast Asian Nations 1967, 3). The UN did not engage as a third-party in the process. However, the UN provided financial support for integration programs through the Action for Conflict Transformation (ACT). As the UN had been successful in El Salvador, it would have certainly been able to handle the peace implementation process in Mindanao adequately. Multi-party efforts in El Salvador and Northern Ireland proved to be successful. International or regional organizations and third countries are not always interested in being involved in peace-making. This may be due to a lack of personal capacity or financial resources. Maybe they do not obtain authorization to act as mediators. 
The OIC kept urging the Philippine government to overcome impediments but was incapable of acting autonomously. In Northern Ireland, the UK and the Republic of Ireland power mediators achieved good implementation results. Although Syria did not succeed in achieving full implementation in Lebanon, it successfully provided security and prevented the occurrence of peace spoilers. The Philippine government's abusive practices violated the ceasefire, caused a breach of confidence and hampered the demarcation of territorial lines. All this could have been prevented, if an additional mediator had been involved in the peace process and would have provided a security guarantee. The UN peacekeeping forces would have been able to balance power between the rival groups and would have kept the peace process going.

My ninth conclusion is about the impact of changeable internal politics on ongoing peace implementation processes. Successive governments in one country do not always have the same peace agenda. As the Philippine Government acted pragmatically and suddenly changed its internal policy in Mindanao because of national elections ahead, the peace process was jeopardized and might have resulted in conflict recurrence. Implementation efforts in terms of power-sharing varied over the years (2001-2010), as different presidents took different approaches to solve the implementation problem (Fidel Ramos, Joseph Estrada, Gloria Macapagal Arroyo). Despite those difficulties, the Autonomous Region of Muslim Mindanao (ARMM) was established. The implementation process was repeatedly postponed due to national elections, numerous ceasefire violations, financial shortcomings, constitutional reviews and standstills, exclusion of conflicting parties, incompatibilities as to timing and regulations in referendums, lack of decommissioning weapons, challenging geographic conditions, the passing of the Republic Acts. The OIC criticized Republic Act No. 9054 for being contrary to the 1976 Tripoli Agreement and the 1996 Mindanao Peace Agreement (OIC 2006, 10).

Foreign financial aid for Mindanao in the post-conflict period proved insufficient compared with the financial support granted to Northern Ireland and El Salvador after their respective peace agreements. Amnesty International and the Country Reports on Human Rights Practices issued by the U.S Department of State repeatedly criticized that human rights were not adequately respected in the Philippines. The socio-economic justice was still not sufficiently 
established ten years after the agreement had been signed. All in all, the implementation process largely depended on the political interests of the Philippine government.

What policy implications could be drawn from the academic findings? As I have reached the theoretical conclusion that multiple power or pure type third-party mediation is crucial to enhance implementation processes, I would like to suggest my triple-team mediation model for successful peace agreement implementation. If two power mediators (from developed countries or Big Five) were to act jointly with the UN (pure mediator), this strong alliance would have a beneficial impact on implementing peace agreements and putting the process on the right track.

Figure 3: Triple-Team of Long-Term Mediators for Peace Agreement Implementation

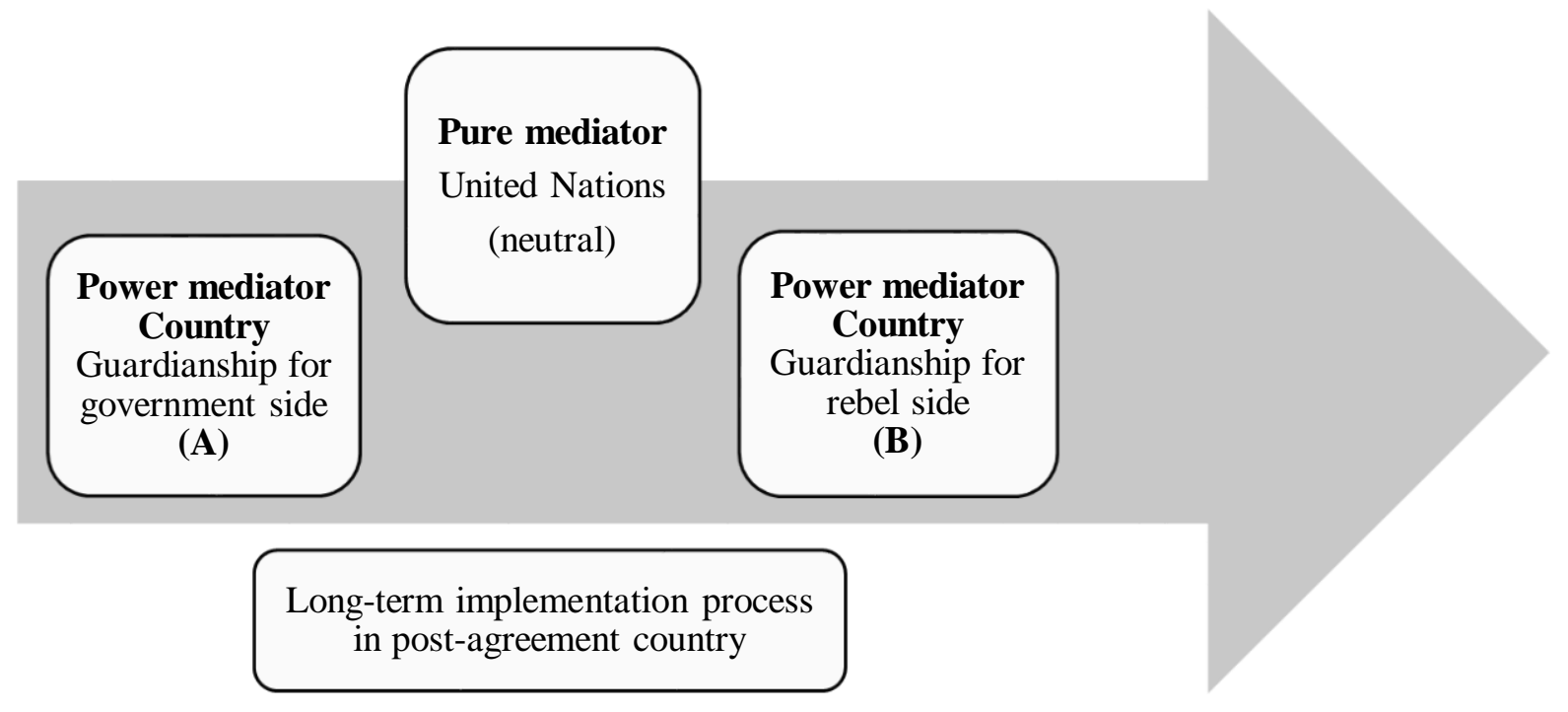

The triple team should be led by the UN, an unbiased pure mediator devoted to global peace and fully conversant with peacebuilding processes. According to the datasets of DeRouen et al. (2011) and Högbladh (2011), multiple third-party mediation with UN participation was identified in countries such as Angola, Burundi, DR Congo, Guatemala, Ivory Coast, Rwanda, 
El Salvador, Guatemala, Somalia, Tajikistan, Comoros Islands, Bosnia-Herzegovina, Cambodia, Croatia, Georgia and Liberia. These examples support the idea of a triple-team performing long-term mediation under UN leadership.

The triple team should closely control rival parties and sufficiently exert pressure on them in case implementation is about to fail. When challenging provisions of power-sharing are to be implemented, the mediators of the triple team should act simultaneously in proper coordination. Ideally, the triple team should take an active part in the negotiation process - in short-term mediation - until a peace agreement has been reached. In the negotiation and mediation processes, the triple team along with their experts should help to formulate every single provision of the peace agreement in details. It is important that third parties quickly acquire specific knowledge of the conflict in the pre-agreement period (history of core incompatibilities and conflict onsets, characteristics of rival parties, conflict types, culture and ideologies), so that they will be able to carefully develop a resolution plan which should not be misinterpreted in the implementation period.

The triple-team might be able to reduce problems as to commitment, postponement and distrust between rival parties. It could constantly eliminate peace spoilers, report obstacles, give security to peacekeepers in the field, maintain the power balance and above all, provide financial support. Mediation and supervision can be mandated in peace agreements and occur in a scheduled time until the agreement has been fully implemented. As an implementation process might take more than ten years, third parties should be fully determined to respect a long-term peace policy. There are always specific national features in each country that might determine a special course of long-term third-party mediation. The powerful triple-team of mediators would be able to successfully tackle problems of political and economic nature. It could help to solve problems such as security, peace spoilers, inequality, inadequate justice procedures in the conflict country.

It can therefore be concluded that successful conflict mediation is a long-term process that requires patience, endurance and dedication. As a peace process comprises conflict mediation, signing a peace agreement and the full implementation of the peace agreement, long-term success should be achieved in different steps: When there is an internal armed conflict 
somewhere, the triple team consisting of power mediators and the UN as a pure (neutral) mediator should convince the conflicting parties A and B of the need of mediation separately. If their mediation attempt is accepted, a ceasefire will be agreed on for further peace talks. The ceasefire agreement should be then replaced by a peace agreement brought about by the triple team. When the peace agreement has been signed, it should be fully implemented with the help of the same triple-team according to an agreed timetable. Ideally, the same triple-team should be there from the beginning till the end of the peace process. So, the work and commitment of experienced short-term mediators would provide the basis for successful implementation processes. Short-term meditators not being directly involved in the implementation process should impart their knowledge to long-term meditators. Good negotiation and persuasion skills enable positive cooperation with the rival parties, which will eventually engender reconciliation and lasting peace. Mediators should be flexible and show psychological sensitivity in long-term mediation. They should never give up and always keep the implementation process running. Responsibilities should be shared by the triple team for specific implementations. Lastly, cutting off foreign military support for civil war-torn countries might greatly facilitate sustainable peace. When the implementation process has been successfully completed in a postagreement society, the triple team's mission has come to an end. 


\section{Bibliography}

Abinales, P. N., and Donna J. Amoroso. 2017. State and Society in the Philippines. Second edition. Lanham; Boulder ; New York; London: Rowman and Littlefield.

Aiken, N. T. 2010. 'Learning to Live Together: Transitional Justice and Intergroup Reconciliation in Northern Ireland'. International Journal of Transitional Justice 4(2): 166-188.

Allansson, Marie. 2017. 'Definitions - Department of Peace and Conflict Research - Uppsala University, Sweden'. https://www.pcr.uu.se/research/ucdp/definitions/ (March 4, 2021).

Amer, Ramses, and Keyuan Zou, eds. 2011. Conflict Management and Dispute Settlement in East Asia. Farnham, Surrey, England; Burlington, VT: Ashgate.

Ampatuan, Linda, Anwar Malang, Tarhata Maglangit, Rodel Manara, Reydan Lacson, Jonathan Domingo, Ustadz Esmael Ebrahim. 2010. 'The Mindanao Think Tank - Recommendations of Prominent Observers of the Peace Process to the New Philippine President'. The Centre for Humanitarian Dialogue, Geneva: 52.

Anfara, Vincent A., and Norma T. Mertz, eds. 2015. Theoretical Frameworks in Qualitative Research. Second edition. Los Angeles: SAGE.

Archick, Kristin. 2017. 'Northern Ireland: Current Issues and Ongoing Challenges in the Peace Process'. Report, Digital Library, March 14.

https://digital.library.unt.edu/ark:/67531/metadc980504/m2/1/high_res_d/RS21 333_2017Mar14.pdf. (March 4, 2021).

Arnault, Jean. 2006. 'GOOD AGREEMENT? BAD AGREEMENT? AN IMPLEMENTATION PERSPECTIVE'. Princeton University: 25. https://gsdrc.org/document-library/good-agreement-bad-agreement-animplementation-perspective/. (March 4, 2021).

Assi, Abbas. 2016. Democracy in Lebanon: Political Parties and the Struggle for Power since Syrian Withdrawal. London New York, NY: I.B. Tauris.

Backer, D. 2010. 'Watching a Bargain Unravel? A Panel Study of Victims' Attitudes about Transitional Justice in Cape Town, South Africa'. International Journal of Transitional Justice 4(3): 443-56.

Baddour, Dylan, and Anthony Faiola. 2019. 'Ex-FARC Leaders Ivan Marquez and Jesus Santrich Take up Arms, Resume Conflict - The Washington Post'. https://www.washingtonpost.com/world/the_americas/as-colombia-peaceaccord-unravels-ex-farc-leaders-take-up-arms-to-resumestruggle/2019/08/29/e2a50bd6-ca5d-11e9-9615-8f1a32962e04_story.html (March 4, 2021). 
Barnett, Hilaire. 2017. Constitutional and Administrative Law. 12th ed. Twelfth edition. | Abingdon, Oxon [UK] ; New York : Routledge, 2017.: Routledge.

Barsalou, Judy. 2008. Trauma and Transitional Justice in Divided Societies. Washington: DIANE Publishing.

Bauzon, Kenneth E. 1999. 'The Philippines: The 1996 Peace Agreement for the Southern Philippines: An Assessment'. Ethnic Studies Report 17(2): 253-80.

BBC News. 2005. 'IRA Guns: The List of Weapons'.

http://news.bbc.co.uk/2/hi/uk_news/northern_ireland/4284048.stm (March 4, 2021).

2007. 'BBC NEWS | Election 2007 | Northern Ireland Elections | Results: Overview'. http://news.bbc.co.uk/2/shared/vote2007/nielection/html/main.stm (March 4, 2021).

2009. 'Timeline: Northern Ireland Assembly'. http://news.bbc.co.uk/2/hi/uk_news/northern_ireland/7932068.stm (March 4, 2021).

2015a. 'BBC NI - Schools - Agreement - Governance - Civic Forum (2)'. http://www.bbc.co.uk/northernireland/schools/agreement/governance/civic2.sh tml (March 4, 2021).

2015b. 'BBC NI - Schools - Agreement - Policing - Commission on Policing for Northern Ireland (4)'.

http://www.bbc.co.uk/northernireland/schools/agreement/policing/commission 4.shtml (March 4, 2021).

2016. 'Colombia Referendum: Voters Reject Farc Peace Deal'. BBC News. https://www.bbc.com/news/world-latin-america-37537252 (March 4, 2021).

2017. 'BBC - History - The Good Friday Agreement'. http://www.bbc.co.uk/history/events/good_friday_agreement (March 4, 2021).

Beardsley, Kyle. 2009. 'Intervention Without Leverage: Explaining the Prevalence of Weak Mediators'. International Interactions 35(3): 272-97.

. 2011. The Mediation Dilemma. Ithaca, N.Y: Cornell University Press.

Bell, C. 2009. 'Transitional Justice, Interdisciplinarity and the State of the "Field" or "NonField”. International Journal of Transitional Justice 3(1): 5-27.

Bell, Christine, and Vanessa Utley. 'Chronology of Mindanao Peace Agreements'. : 13. https://www.politicalsettlements.org/publications-database/chronology-ofmindanao-peace-agreements/.(March 3, 2021). 
Bellamy, Alex J. 2009. Responsibility to Protect: The Global Effort to End Mass Atrocities. Cambridge ; Malden, MA: Polity.

Benítez, Pablo. 2011. 'El Salvador, 1932: Los Cofrades Insurrectos. Herencia Corporativa Colonial En La Sociedad Salvadoreña'. DOSSIER EL SALVADOR: 31. shorturl.at/gyV67 (March 3, 2021).

Bennett, Andrew. 2004. 'Case Study Methods: Design, Use, and Comparative Advantages'. Models, numbers, and cases: Methods for studying international relations: 1955.

Bercovitch, Jacob. 1991. 'International Mediation and Dispute Settlement: Evaluating the Conditions for Successful Mediation'. Negotiation Journal 7(1): 17-30.

, ed. 1996. Resolving International Conflicts: The Theory and Practice of Mediation. Boulder, Colo: Lynne Rienner Publishers.

2007. 'MEDIATION SUCCESS OR FAILURE: A SEARCH FOR THE ELUSIVE CRITERIA'. : 14. https://cardozojcr.com/vol7no2/CAC206.pdf.

2011. Theory and Practice of International Mediation: Selected Essays. London: Routledge.

Bercovitch, Jacob, and Karl Derouen. 2004. 'Mediation in Internationalized Ethnic Conflicts: Assessing the Determinants of a Successful Process'. Armed Forces and Society 30(2): 147-70.

Bercovitch, Jacob, and Karl DeRouen. 2005. 'Managing Ethnic Civil Wars: Assessing the Determinants of Successful Mediation'. Civil Wars 7(1): 98-116. ht

Bercovitch, Jacob, and Scott Sigmund Gartner, eds. 2009. International Conflict Mediation: New Approaches and Findings. London: Routledge.

Bercovitch, Jacob, and Jeffrey Z Rubin. 1992. Mediation in International Relations: Multiple Approaches to Conflict Management. Basingstoke: Palgrave Macmillan.

Bercovitch, Jacob, and Leah Simpson. 2010. 'International Mediation and the Question of Failed Peace Agreements: Improving Conflict Management and Implementation'. Peace and Change 35(1): 68-103.

BIIC, 2006. Meetings of the British-Irish Intergovernmental Conference. In: http://cain.ulst.ac.uk/issues/politics/conference/biic010206.htm (March 3, 2021).

Binningsb $\varnothing$, Helga Malmin. 2013. 'Power Sharing, Peace and Democracy: Any Obvious Relationships?' International Area Studies Review 16(1): 89-112. 
Binningsbø, Helga Malmin, and Kendra Dupuy. 2009. 'Using Power-Sharing to Win a War: The Implementation of the Lomé Agreement in Sierra Leone'. Africa Spectrum 44(3): 87-107.

Biro, Miklos, Dean Ajdukovic, Dinka Corkalo, Dino Djipa, Petar Milin, and Harvey M. Weinstein, eds. 2004. 'Attitudes toward Justice and Social Reconstruction in Bosnia and Herzegovina and Croatia'. In My Neighbor, My Enemy, eds. Eric Stover and Harvey M. Weinstein. Cambridge University Press, 183-205.

Boxcar-admin. 2019. 'Implementations Archive - Page 147 of 688'. Peace Accords Matrix. https://peaceaccords.nd.edu/implementation (March 6, 2021).

Böhmelt, Tobias. 2012. 'Why Many Cooks If They Can Spoil the Broth? The Determinants of Multiparty Mediation'. Journal of Peace Research 49(5): 701-15.

Boutros-Ghali, Boutros, ed. 1995. The United Nations and El Salvador, 1990-1995. New York, NY: United Nations, Dept. of Public Information.

Brahm, Eric. 2007. 'Transitional Justice, Civil Society, and the Development of the Rule of Law in Post-Conflict Societies'. ICNL.

https://www.icnl.org/resources/research/ijnl/transitional-justice-civil-societyand-the-development-of-the-rule-of-law-in-post-conflict-societies (March 3, 2021).

Buergenthal, Thomas. 1994. The united nations truth commission for el salvador. Vanderbilt Journal of Transnational Law, 27(3), 497-544.

'CAIN: Issues: Politics: Joint Commuinque of the British-Irish Intergovernmental Conference (BIIC), London, 1 February 2006'. https://cain.ulster.ac.uk/issues/politics/conference/biic010206.htm (March 3, 2021).

'CAIN: Issues: Politics: Joint Commuinque of the British-Irish Intergovernmental Conference (BIIC), London, 17 December 1999’. 1999. https://cain.ulster.ac.uk/issues/politics/conference/biic171299.htm (March 3, 2021).

Call, Charles. 2012. Why Peace Fails: The Causes and Prevention of Civil War Recurrence. Washington, DC: Georgetown University Press.

Call, Charles T. 2002. 'Assessing El Salvador's Transition From Civil War to Peace'. https://dra.american.edu/islandora/object/auislandora\%3A53342/ (March 3, 2021).

Carnevale, Peter J, and Sharon Arad. 1996. 'Bias and Impartiality in International Mediation'. Resolving international conflicts: The theory and practice of mediation: 39-53. 
Castillo, Graciana Del. 1997. 'The Arms-for-Land Deal in El Salvador'. In Keeping the Peace, eds. Michael W. Doyle, Ian Johnstone, and Robert C. Orr. Cambridge University Press, 342-66.

Castillo, Graciana del. 2008. Rebuilding War-Torn States: The Challenge of Post-Conflict Economic Reconstruction. Oxford ; New York: Oxford University Press.

Cavendish, Marshall. 2007. 'World and Its Peoples: Eastern and Southern Asia'. Marshall Cavendish Corporation 1: 268-69.

Chavez, Lydia. 1984. 'SALVADOR CHURCH ACTING AS MEDIATOR'. The New York Times. https://www.nytimes.com/1984/06/12/world/salvador-church-acting-asmediator.html (March 3, 2021).

CISAC. 2019. 'MMP: Moro Islamic Liberation Front'. https://cisac.fsi.stanford.edu/mappingmilitants/profiles/moro-islamicliberation-front (March 3, 2021).

Clayton, Govinda. 2013. 'Relative Rebel Strength and the Onset and Outcome of Civil War Mediation'. Journal of Peace Research 50(5): 609-22.

Collier, Paul, V. L. Elliott, Håvard Hegre, Anke Hoeffler, Marta Reynal-Querol, Nicholas Sambanis. 2003. Breaking the Conflict Trap: Civil War and Development Policy. Washington, DC : [New York]: World Bank ; Oxford University Press.

Connolly, Christopher K. 2006. 'Living on the Past: The Role of Truth Commissions in PostConflict Societies and the Case Study of Northern Ireland'. Cornell International Law Journal 39: 35.

Cousens, Elizabeth. 2008. 'It Ain't Over 'Til It's Over: What Role for Mediation in PostAgreement Contexts?' : 7. https://www.files.ethz.ch/isn/90795/Aint_Over_06_08.pdf. (March 3, 2021).

Crocker, Chester A., Fen Osler Hampson, and Pamela R. Aall, eds. 1999a. Herding Cats: Multiparty Mediation in a Complex World. Washington, D.C: United States Institute of Peace Press.

Crocker, D. 'Truth Commissions, Transitional Justice and Civil Society'. GSDRC. https://gsdrc.org/document-library/truth-commissions-transitional-justice-andcivil-society/ (March 3, 2021).

Cuevas, Victor Espinoza, María Luisa Ortiz Rojas Víctor, and Paz Rojas Baeza. 2002. 'Truth Commissions: An Uncertain Path?' : 48. https://www.files.ethz.ch/isn/103018/Truth_Comm_Executive_Summary.pdf. (March 3, 2021).

Darby, John. 1995. 'Conflict in Northern Ireland: A Background Essay'. In Facets of the Conflict in Northern Ireland, ed. Seamus Dunn. London: Palgrave Macmillan UK, 15-23. 
Debraggio, Joseph Michael. 2010. 'Implementing The Good Friday Agreement: Overcoming Challenges and Obstacles'. : 96.

https://digitalcommons.bucknell.edu/cgi/viewcontent.cgi?article=1024andcont ext=honors_theses.

DeRouen Jr, Karl, Mark J. Ferguson, Samuel Norton, Young Hwan Park, Jenna Lea, and Ashley Streat-Bartlett. 2010. 'Civil War Peace Agreement Implementation and State Capacity'. Journal of Peace Research 47(3): 333-46.

DeRouen Jr, Karl, Jacob Bercovitch, and Paulina Pospieszna. 2011. 'Introducing the Civil Wars Mediation (CWM) Dataset'. Journal of Peace Research 48(5): 663-72.

DeRouen Jr, Karl, and Ishita Chowdhury. 2018. 'Mediation, Peacekeeping and Civil War Peace Agreements'. Defence and Peace Economics 29(2): 130-46.

DeRouen, Karl, and Ishita Chowdhury. 2013. 'Mediation and Civil War Peace Agreement Implementation'.

Derouen, Karl, Jenna Lea, and Peter Wallensteen. 2009. 'The Duration of Civil War Peace Agreements*'. Conflict Management and Peace Science 26(4): 367-87.

De Soto, Alvaro, and Graciana del Castillo. 1995. 'Implementation of Comprehensive Peace Agreements: Staying the Course in El Salvador'. Global Governance 1(2): 189-204.

Dictaan-Bang-oa, Eleanor. 2004. 'The Question of Peace Mindanao Southern Philippines'. Beyond the Silencing of the Guns: 153-84.

Dong, Lan, ed. 2016. Asian American Culture: From Anime to Tiger Moms. First edition. Santa Barbara, California: Greenwood, an imprint of ABC-CLIO, LLC.

Dorney, John. 2015. 'The Northern Ireland Conflict 1968-1998 - An Overview - The Irish Story'. https://www.theirishstory.com/2015/02/09/the-northern-irelandconflict-1968-1998-an-overview/\#.YEORRC1XZQI (March 3, 2021).

Doyle, Michael W, and Nicholas Sambanis. 2006. Making War and Building Peace: United Nations Peace Operations. Princeton University Press.

Dunn, Seamus, and Jacqueline Nolan-Haley. 1998. 'Conflict in Northern Ireland After the Good Friday Agreement'. Fordham Int'l LJ 22: 1372.

Duursma, Allard. 2014. 'A Current Literature Review of International Mediation'. International Journal of Conflict Management.

El- Zein, Fares, and Holly Sims. 2004. 'Reforming War's Administrative Rubble in Lebanon'. Public Administration and Development: The International Journal of Management Research and Practice 24(4): 279-88. 
Enders, Jürgen. 'Libanon'. https://www.wiso.uni-hamburg.de/fachbereichsowi/professuren/jakobeit/forschung/akuf/kriegearchiv/vorderer-und-mittlererorient/libanon.html (March 3, 2021).

Eriksson, John R., Alcira Kreimer, and Margaret Arnold. 2000. El Salvador: Post-Conflict Reconstruction: Country Case Evaluation. Washington, D.C: World Bank.

Feagin, Joe R., Anthony M. Orum, and Gideon Sjoberg, eds. 1991. A Case for the Case Study. Chapel Hill: University of North Carolina Press.

Fontana, Giuditta. 2017. Education Policy and Power-Sharing in Post-Conflict Societies: Lebanon, Northern Ireland, and Macedonia. Cham: Palgrave Macmillan.

Fortna, Virginia Page. 2004. 'Does Peacekeeping Keep Peace? International Intervention and the Duration of Peace After Civil War'. International Studies Quarterly 48(2): 269-92.

Frei, Daniel. 1975. 'Erfolgsbedingungen Für Vermittlungsaktionen in Internationalen Konflikten'. Politische Vierteljahresschrift 16(4): 447-90.

1976. 'Conditions Affecting the Effectiveness of International Mediation'. Peace Science Society (International) Papers 26(1): 67-84.

Friedrich, Carl J. 1947. 'The Ideology of the United Nations Charter and the Philosophy of Peace of Immanuel Kant 1795-1945'. The Journal of Politics 9(1): 10-30.

Gade, Tine, and Are John Knudsen, eds. 2017. Civil-Military Relations in Lebanon: Conflict, Cohesion and Confessionalism in a Divided Society. 1st ed. 2017. Cham: Springer International Publishing : Imprint: Palgrave Macmillan.

Galtung, Johan. 1969. 'Violence, Peace, and Peace Research'. Journal of Peace Research 6(3): 167-91.

Gates, Scott, Håvard Mokleiv Nygård, Håvard Strand, and Henrik Urdal. 2016. 'Trends in Armed Conflict, 1946-2014'. Conflict Trends 1: 1-4.

Gerring, John. 2004. 'What Is a Case Study and What Is It Good For?' American political science review: $341-54$.

Ghoniem, Amira A. 2003. 'United Nations Peacekeeping Operations: Improvements for Mission Success'. Ethics of Development in a Global Environment: 1-26.

Ginty, R. Mac, and Roger Mac Ginty. 2016. No War, No Peace: The Rejuvenation of Stalled Peace Processes and Peace Accords. London: Palgrave Macmillan UK.

Gissel, Line Engbo. 2015. 'Justice Tides: How and When Levels of ICC Involvement Affect Peace Processes'. International Journal of Transitional Justice 9(3): 428-48. 
González Enríquez, Carmen, Alexandra Barahona de Brito, and Paloma Aguilar Fernández, eds. 2001. The Politics of Memory: Transitional Justice in Democratizing Societies. Oxford: Oxford University Press.

Gov.ie. 2016. 'Referendums Results 1937-2015.'

https://www.gov.ie/en/organisation/department-of-housing-local-governmentand-heritage/?referrer=http://www.housing.gov.ie/sites/default/files/migratedfiles/en/Publications/LocalGovernment/Voting/referendum_results_19372015.pdf (March 4, 2021).

Gov.uk. 1998. 'The Belfast Agreement'. GOV.UK.

https://www.gov.uk/government/publications/the-belfast-agreement (March 4, 2021).

Greig, J Michael, and Patrick M Regan. 2008. 'When Do They Say Yes? An Analysis of the Willingness to Offer and Accept Mediation in Civil Wars'. International Studies Quarterly 52(4): 759-81.

Halili, Christine N. 2006. Philippine History. Manila: Rex Book Store.

Harb, Mona, and Sami Atallah. 2015. 'Lebanon: A Fragmented and Incomplete Decentralization'. Local governments and public goods: Assessing decentralization in the Arab world 187.

Harris, Peter, and International Institute for Democracy and Electoral Assistance, eds. 2003. Democracy and Deep-Rooted Conflict: Options for Negotiators. Reprinted. Stockholm: IDEA.

Hartzell, Caroline, and Matthew Hoddie. 2003. 'Institutionalizing Peace: Power Sharing and Post- civil War Conflict Management'. American Journal of Political Science 47(2): $318-32$.

Hartzell, Caroline, Matthew Hoddie, and Donald Rothchild. 2001. 'Stabilizing the Peace after Civil War: An Investigation of Some Key Variables'. International organization: 183-208.

Hazell, Robert, and Constitution Unit, eds. 2000. The State and the Nations: The First Year of Devolution in the United Kingdom. Thorverton: Imprint Acad. [u.a.].

Heard, John, and Lisa Magno. 2000. 'Office of Transition Initiatives Bureau for Humanitarian Response United States Agency for International Development'. : 28. https://www.syrialearning.org/system/files/content/resource/files/main/erd2974-full.pdf.

HD Centre for Humanitarian Dialogue. 2007. 'Charting the Roads to Peace: Facts, Figures and Trends in Conflict Resolution'. 2007. HD Centre for Humanitarian Dialogue: 24.

https://www.files.ethz.ch/isn/39741/07_oslo_charting_FINAL.pdf. (March 3, 2021). 
Heemsbergen, Luke, and Asaf Siniver. 2011. 'New Routes to Power: Towards a Typology of Power Mediation'. Review of international studies: 1169-90.

Herbolzheimer, Kristian. 2015. 'The Peace Process in Mindanao, the Philippines: Evolution and Lessons Learned'. The International Relations and Security Network 17.

Herrhausen, Anna. 2007. 'Coordination in United Nations Peacebuilding-a Theory-Guided Approach'.

HIIK. 2016. Conflict Barometer.

http://www.turningpoints.eu/facts/ewExternalFiles/Conflict\%20Barometer\%20 2015.pdf (October 26, 2016).

Hodali, Diana. 2018. 'Libanon | bpb'. bpb.de.

https://www.bpb.de/internationales/weltweit/innerstaatliche-

konflikte/54644/libanon (March 4, 2021).

Hoddie, Matthew, and Caroline Hartzell. 2003. 'Civil War Settlements and the Implementation of Military Power-Sharing Arrangements'. Journal of Peace Research 40(3): 303-20.

Högbladh, Stina. 2011. 'Peace Agreements 1975-2011-Updating the UCDP Peace Agreement Dataset'. States in armed conflict 55: 85-105.

Hopmann, P Terrence. 1999. 31 Building Security in Post-Cold War Eurasia: The OSCE and US Foreign Policy. Washington, DC: United States Institute of Peace.

2000. 'The Organization for Security and Cooperation in Europe: Its Contribution to Conflict Prevention and Resolution'. CONFLICT RESOLUTION: 569-615.

Human Rights Watch. 2009. 'Lebanon: Removal of Religion from IDs Positive but Not Sufficient'. Human Rights Watch.

https://www.hrw.org/news/2009/02/16/lebanon-removal-religion-ids-positivenot-sufficient (March 4, 2021).

Iag.org.ph. 2015. 'Muslim Mindanao Autonomy Policy Report, Opt in and Opt Out: History, Context and Issues on Territory'. IAG.

https://www.iag.org.ph/index.php/blog/1274-muslim-mindanao-autonomypolicy-report-opt-in-and-opt-out-history-context-and-issues-on-territory (March 4, 2021).

IICD. 2001. 'CAIN: Events: Peace: Statement by the Independent International Commission on Decommissioning (IICD), 30 May 2001'. https://cain.ulster.ac.uk/events/peace/decommission/iicd300501.htm (March 4, 2021).

International Center for Transitional Justice. 2009. 'What Is Transitional Justice?'

International Center for Transitional Justice.

https://www.ictj.org/publication/what-transitional-justice (March 4, 2021). 
International Foundation for Electoral Systems. 2009. 'Lebanon's Constitutional Council'. https://www.ifes.org/publications/lebanons-constitutional-council (March 4, 2021).

Isaacs, Anita. 2010. 'At War with the Past? The Politics of Truth Seeking in Guatemala'. International Journal of Transitional Justice 4(2): 251-74.

Jarstad, Anna K, and Desirée Nilsson. 2008. 'From Words to Deeds: The Implementation of Power-Sharing Pacts in Peace Accords'. Conflict management and peace science 25(3): 206-23.

Jarstad, Anna K, and Timothy D Sisk. 2008. From War to Democracy: Dilemmas of Peacebuilding. Cambridge University Press.

Jetschke, Anja. 2011. Human Rights and State Security: Indonesia and the Philippines. Philadelphia: University of Pennsylvania Press.

Jones, Bruce D. 2001. The Challenges of Strategic Coordination: Containing Opposition and Sustaining Implementation of Peace Agreements in Civil Wars. International Peace Academy Nueva York. https://www.ipinst.org/wpcontent/uploads/publications/pdf_report_challenges.pdf. (March 3, 2021).

Joshi, Madhav, and John Darby. 2013. 'Introducing the Peace Accords Matrix (PAM): A Database of Comprehensive Peace Agreements and Their Implementation, 1989-2007'. Peacebuilding 1(2): 256-74.

Joshi, Madhav, Jason Michael Quinn, and Patrick M Regan. 2015. 'Annualized

Implementation Data on Comprehensive Intrastate Peace Accords, 19892012'. Journal of Peace Research 52(4): 551-62.

Juhn, Tricia. 2016. Negotiating Peace in El Salvador: Civil-Military Relations and the Conspiracy to End the War. London: Palgrave Macmillan Limited.

Kant, Immanuel. 1970. Perpetual Peace: A Philosophical Sketch. Indianapolis and Cambridge: Cambridge University Press Cambridge.

Karakus, Dogukan Cansin. 2015a. Friedens- und Konfliktbearbeitung in Bürgerkriegen: Regional-institutionelle Friedensmissionen im Kosovo, in BosnienHerzegowina, Liberia und Sierra Leone. Hamburg: Diplomica Verlag.

. 2015b. Minderheitenpolitik der Türkei und Spaniens: Ein Vergleich zwischen den Minderheiten der Basken in Spanien und der Kurden in der Türkei hinsichtlich ihrer Sprach- und Bildungsfreiheit innerhalb der jeweiligen Gesetzgebung. Hamburg: Diplomica Verlag.

Karam, Karam. 2012. 'The Taif Agreement: New Order, Old Framework'. Picard, E., and Ramsbotham, A., Reconciliation, reform and resilience: Positive peace for Lebanon. 
Kleiboer, Marieke. 1996. 'Understanding Success and Failure of International Mediation'. Journal of Conflict resolution 40(2): 360-89.

1998. The Multiple Realities of International Mediation. Boulder, Colo: Lynne Rienner Publishers.

Knio, Karim. 2005. 'Lebanon: Cedar Revolution or Neo-Sectarian Partition?' Mediterranean Politics 10(2): 225-31.

Kohen, Marcelo G., ed. 2006. Secession: International Law Perspectives. Cambridge, UK ; New York: Cambridge University Press.

Kraft, Herman Joseph S. 2010. 'The Foibles of an Armed Citizenry: Armed Auxiliaries of the State and Private Armed Groups in the Philippines (Overview)'. Soliman M. Santos, Jr. and Paz Verdades M. Santos. Primed and Purposeful: Armed Groups and Human Security Efforts in the Philippines: 185-212.

Krayem, Hassan. 1997. 'The Lebanese Civil War and the Taif Agreement'. Conflict resolution in the Arab world: Selected essays: 411-36.

Krennerich, Michael. 2013. 6 Wahlen Und Antiregimekriege in Zentralamerika: Eine Vergleichende Studie. Wiesbaden: Springer-Verlag.

Kreutz, Joakim. 2010. 'How and When Armed Conflicts End: Introducing the UCDP Conflict Termination Dataset'. Journal of Peace Research 47(2): 243-50.

Kritz, Neil J., ed. 1995. Transitional Justice: How Emerging Democracies Reckon with Former Regimes. Vol. 2: Country Studies. Washington, DC: United States Inst. of Peace Press.

Lambourne, Wendy. 2009. 'Transitional Justice and Peacebuilding after Mass Violence'. International journal of transitional justice 3(1): 28-48.

Lawphil. 2018. 'R.A. No. 9054'.

https://lawphil.net/statutes/repacts/ra2001/ra_9054_2001.html\#top (March 4, 2021).

_. 2021. 'E.O. No. 371'.

https://lawphil.net/executive/execord/eo1989/eo_371_1989.html (March 4, 2021).

Lee, SungYong, Roger Mac Ginty, and Madhav Joshi. 2016. 'Social Peace vs. Security Peace'. Global Governance: A Review of Multilateralism and International Organizations 22(4): 491-512.

Legislation.gov.uk. 1998. 'Education (Northern Ireland) Order 1998'. https://www.legislation.gov.uk/nisi/1998/1759 (March 4, 2021). 
. 2000. 'The Flags Regulations (Northern Ireland) 2000'. https://www.legislation.gov.uk/nisr/2000/347/contents/made (March 4, 2021).

- 2006. 'The Victims and Survivors (Northern Ireland) Order 2006'. https://www.legislation.gov.uk/nisi/2006/2953/article/5\#commentaryc21178491 (March 4, 2021).

Lijphart, Arend. 1969. 'Consociational Democracy’. World Politics 21(2): 207-25.

Lingga, Abhoud Syed M. 2006. 'Role of Third Parties in Mindanao Peace Process'. Autonomy and Peace Review 2: 83-104.

Lundgren, Magnus. 2017. 'Which type of international organizations can settle civil wars?'. The Review of International Organizations 12(4): 613-641.

Lundy, Patricia, and Mark McGovern. 2008. 'Whose Justice? Rethinking Transitional Justice from the Bottom Up'. Journal of law and society 35(2): 265-92.

Mac Ginty, Roger, Orla T Muldoon, and Neil Ferguson. 2007. 'No War, No Peace: Northern Ireland after the Agreement'. Political psychology 28(1): 1-11.

Mahoney, James. 2007. 'Qualitative Methodology and Comparative Politics'. Comparative political studies 40(2): 122-44.

Makinano, Merliza M, and Alfredo Lubang. 2001. Disarmament, Demobilization and Reintegration: The Mindanao Experience. Ottawa: Department of Foreign Affairs and International Trade Ottawa.

Mattes, Michaela, and Burcu Savun. 2009. 'Fostering Peace after Civil War: Commitment Problems and Agreement Design'. International studies quarterly 53(3): 73759.

- 2010. 'Information, Agreement Design, and the Durability of Civil War Settlements'. American Journal of Political Science 54(2): 511-24.

May, Stephen. 2012. Language and Minority Rights: Ethnicity, Nationalism and the Politics of Language. 2nd ed. New York: Routledge.

Mazzei, Julie. 2009. Death Squads or Self-Defense Forces? How Paramilitary Groups Emerge and Challenge Democracy in Latin America. Chapel Hill: University of North Carolina Press.

McCabe, Zachary E. 2001. 'The Northern Ireland: The Paramilitaries, Terrorism, and September 11th'. Denv. J. Int'l L. and Pol'y 30: 547.

McCarney, W. 1996. 'The Origin of the Troubles in Northern Ireland: An Historical Background'. Juvenile and Family Court Journal 47(1): 76-82. 
McKenna, Fionnuala. 2000. 'CAIN: Issues: Law: Criminal Justice System Review Report, 30 March 2000'. https://cain.ulster.ac.uk/issues/law/cjr/report30300.htm (March $3,2021)$.

McKernan, Michael, and Owen McQuade. 2004. Northern Ireland Yearbook 2005, A Comprehensive Reference Guide to the Political, Economic and Social Life of Northern Ireland. Moira: BMF Pub.

Melander, Erik. 2009. Justice or Peace: A Statistical Study of the Relationship between Amnesties and Durable Peace. Lund University.

Melander, Erik, Frida Möller, and Magnus Öberg. 2009. 'Managing Intrastate Low-Intensity Armed Conflict 1993-2004, A New Dataset'. International Interactions 35(1): $58-85$.

Melaugh, Martin, and Fionnuala McKenna. 1998. 'CAIN: Issue: Politics: Elections: Assembly Election (NI) Thursday 25 June 1998'.

https://cain.ulster.ac.uk/issues/politics/election/ra1998.htm (March 3, 2021).

Melin, Molly M, and Isak Svensson. 2009. 'Incentives for Talking: Accepting Mediation in International and Civil Wars'. International Interactions 35(3): 249-71.

Mendeloff, David. 2009. 'Trauma and Vengeance: Assessing the Psychological and Emotional Effects of Post-Conflict Justice'. Hum. Rts. Q. 31: 592.

Menninga, Elizabeth. 2015. 'Multiparty Mediation: Identifying Characteristics of the Mediation Dream Team'. University of North Carolina at Chapel Hill Graduate School. https://cdr.lib.unc.edu/concern/dissertations/b5644s66d?locale=en (March 3, 2021).

Montgomery, Tornmie Sue. 1995. 'Getting to Peace in El Salvador: The Roles of the United Nations Secretariat and ONUSAL'. Journal of Interamerican Studies and World Affairs 37(4): 139-72.

Nathan, Laurie. 1999. 'International Mediation in African Civil Wars'. Global Dialogue 8(2).

National Research Council. 2000 International conflict resolution after the Cold War. Washington, DC: National Academy Press.

Negroponte, Diana Villiers. 2012. Seeking Peace in El Salvador the Struggle to Reconstruct a Nation at the End of the Cold War. Basingstoke: Palgrave Macmillan.

Nielsen, Richard A. 2016. 'Case Selection via Matching'. Sociological Methods and Research 45(3): 569-97.

NIHRC. 1999. '1st Commission Minutes 1st March 1999 NI Human Rights Commission (NIHRC)'. https://www.nihrc.org/index.php?/publication/detail/commissionmeeting-march-1999-no.1 (March 4, 2021). 
Nolan, James L., ed. 1996. Philippines Business: The Portable Encyclopedia for Doing Business with the Philippines. San Rafael, Calif., USA: World Trade Press.

Nolan, Paul. 2012. The Northern Ireland peace monitoring report: Number 1. Belfast: Northern Ireland Community Relations Council. https://www.communityrelations.org.uk/sites/crc/files/media-files/NIPMR\%201.pdf (March 4, 2021).

Nolan, Paul, and Dominic Bryan. 2016. 'Flags: Towards a New Understanding'. Belfast: Institute of Irish Studies, Queens University.

North South Ministerial Council. 1999. 'Inaugural Plenary Joint Communiqué 13 December 1999'. North South Ministerial Council.

https://www.northsouthministerialcouncil.org/publications/inaugural-plenaryjoint-communique-13-december-1999 (March 4, 2021).

Obe, Geraldine McGahey, and Carmel McKinney Obe. 1998. 'Commissioners Set the Overall Strategic Direction for the Organisation, Set the Policy Framework and Oversee the Delivery of the Planned Work. With the Exception of the Chief Commissioner, All Commissioners Are Part Time and Are Appointed for a Three Year Term.' : 14. https://www.equalityni.org/ECNI/media/ECNI/Publications/Corporate/Welco metoECNI.pdf.

Ockerbloom, John Mark. 1990. 'Country Reports on Human Rights Practices (Lebanon)'. http://onlinebooks.library.upenn.edu/webbin/serial?id=crhrp (March 4, 2021).

1991. 'Country Reports on Human Rights Practices (Lebanon)'. http://onlinebooks.library.upenn.edu/webbin/serial?id=crhrp (March 4, 2021).

1993. 'Country Reports on Human Rights Practices (CRHRP) (Lebanon)'. http://dosfan.lib.uic.edu/ERC/democracy.html (January 26, 2017).

1994. 'Country Reports on Human Rights Practices (CRHRP) (Lebanon)'. http://dosfan.lib.uic.edu/ERC/democracy/1993_hrp_report/93hrp_report_nea/L ebanon.html (March 4, 2021).

1995. 'Country Reports on Human Rights Practices (CRHRP) (Lebanon)'. http://dosfan.lib.uic.edu/ERC/democracy.html (January 26, 2017).

OIC. 2006. Reports of the Secretary-General on Muslim Minorities and Communities in NonOIC Member States Submitted to the 33rd Session of the Islamic Conference of Foreign Ministers. Baku. https://goo.gl/ZU5AGJ (March 4, 2021).

Özerdem, Alpaslan. 2012. 'The Contribution of the Organisation of the Islamic Conference to the Peace Process in Mindanao'. Civil Wars 14(3): 393-413.

Patten, Chris. 1999. A New Beginning: Policing in Northern Ireland. Stationery Office. 
Peetz, Peter. 2008. 'bpb.de - Dossier Lateinamerika - El Salvador - jüngste Geschichte und Gegenwart'. bpb.de.

https://www.bpb.de/internationales/amerika/lateinamerika/44868/geschichte (March 4, 2021).

Perry, Valery. 2009. 'At Cross Purposes? Democratization and Peace Implementation Strategies in Bosnia and Herzegovina's Frozen Conflict'. Human Rights Review 10(1): 35-54.

Pettersson, Therése, Stina Högbladh, and Magnus Öberg. 2019. 'Organized Violence, 19892018 and Peace Agreements'. Journal of Peace Research 56(4): 589-603.

Pham, Phuong N, Harvey M Weinstein, and Timothy Longman. 2004. 'Trauma and PTSD Symptoms in Rwanda: Implications for Attitudes toward Justice and Reconciliation'. Jama 292(5): 602-12.

Pham, Phuong, and Patrick Vinck. 2010. 'Transitioning to Peace: A Population-Based Survey on Attitudes about Social Reconstruction and Justice in Northern Uganda'. UC Berkeley Initiative for Vulnerable Populations.

Picard, Elizabeth, and Alexander Ramsbotham. 2012. 'Reconciliation, Reform and Resilience Positive Peace for Lebanon'. : London. https://halshs.archivesouvertes.fr/halshs-00741581/document.

Police Service of Northern Ireland. 2017. 'Workforce Composition Statistics'. https://www.psni.police.uk/inside-psni/Statistics/workforce-compositionstatistics/ (March 4, 2021).

Popkin, Margaret. 2010. Peace without Justice: Obstacles to Building the Rule of Law in El Salvador. University Park, Pennsylvania: Penn State Press.

Pospieszna, Paulina, and Gerald Schneider. 2011. 'Power Sharing Provisions and Long-Term Success of Mediation in Internal Conflicts'.

Potter, Michael, and Anne Campbell. 2014. 'Funding for Victims and Survivors Groups in Northern Ireland'. shorturl.at/jxET2 (March 4, 2021).

Pugh, Jeffrey. 2009. 'The Structure of Negotiation: Lessons from E1 Salvador for Contemporary Conflict Resolution'. Negotiation Journal 25(1): 83-105.

Ramsbotham, Oliver, Hugh Miall, and Tom Woodhouse. 2011. Contemporary Conflict Resolution: The Prevention, Management and Transformation of Deadly Conflicts. 3rd ed. Cambridge, UK; Malden, MA: Polity.

Reiter, Andrew G. 2016. Fighting Over Peace: Spoilers, Peace Agreements, and the Strategic Use of Violence. 1st ed. 2016. Cham: Springer International Publishing : Imprint: Palgrave Macmillan. 
Rihoux, Benoît, and Charles C Ragin. 2009. Configurational Comparative Methods Qualitative Comparative Analysis (QCA) and Related Techniques. Thousand Oaks, Calif.; London: SAGE.

Riley, Jim. 2000. 'The 1998 Referendums'. https://www.ark.ac.uk/elections/fref98.htm (March 3, 2021).

Robins, Simon. 2011. 'Towards Victim-Centred Transitional Justice: Understanding the Needs of Families of the Disappeared in Postconflict Nepal'. International Journal of Transitional Justice 5(1): 75-98.

Roht-Arriaza, Naomi, and Javier Mariezcurrena. 2006. Transitional Justice in the TwentyFirst Century: Beyond Truth versus Justice. Cambridge: Cambridge University Press.

Rosiny, Stephan. 2015. 'A Quarter Century of “Transitory Power-Sharing”. Lebanon's Unfulfilled Ta'if Agreement of 1989 Revisited'. Civil Wars 17(4): 485-502.

Salloukh, Bassel. 2005. 'Syria and Lebanon: A Brotherhood Transformed'. Middle East Report (236): 14-21.

Salloukh, Bassel F. 2006. 'The Limits of Electoral Engineering in Divided Societies: Elections in Postwar Lebanon'. Canadian Journal of Political Science/Revue canadienne de science politique: $635-55$.

Sambanis, Nicholas. 2008. 'Short-and Long-Term Effects of United Nations Peace Operations'. The World Bank Economic Review 22(1): 9-32.

Samii, Cyrus. 2011. 'Microdynamics of War-to-Peace Transitions: Evidence from Burundi'. https://academiccommons.columbia.edu/doi/10.7916/D8736XVW (March 3, 2021).

Sandu, Ciprian. 2013. 'Mediation. Measuring the Success of Mediation'. Conflict Studies Quarterly 2: 30-39.

Santos Jr, Soliman M. 2010. 'MNLF Integration into the AFP and the PNP: Successful Cooptation or Failed Transformation? (Case Study)'. Primed and purposeful: Armed groups and human security efforts in the Philippines: 162-84.

Savun, Burcu. 2008. 'Information, Bias, and Mediation Success'. International studies quarterly 52(1): 25-47.

Sciboz, Joëlle. 2018. 'Research Guides: Security Council - Quick Links: Vetoes'. https://research.un.org/en/docs/sc/quick/veto (March 4, 2021).

Shaw, Rosalind, Lars Waldorf, and Pierre Hazan, eds. 2010. Localizing transitional justice: Interventions and priorities after mass violence. Stanford: Stanford University Press, 2010. 
Seawright, Jason, and John Gerring. 2008. 'Case Selection Techniques in Case Study

Research: A Menu of Qualitative and Quantitative Options'. Political research quarterly 61(2): 294-308.

Sisk, Timothy D. 1996. Power Sharing and International Mediation in Ethnic Conflicts. Washington, D.C: United States Institute of Peace Press.

Sisk, Timothy D. 2009. International Mediation in Civil Wars: Bargaining with Bullets. London.

Slomich, Joshua. 1998. 'The Ta'if Accord: Legalizing the Syrian Occupation of Lebanon'. Suffolk Transnat'l L. Rev. 22: 619.

Sobek, David. 2010. 'Masters of Their Domains: The Role of State Capacity in Civil Wars'.

Spears, Ian S. 2000. 'Understanding Inclusive Peace Agreements in Africa: The Problems of Sharing Power'. Third World Quarterly 21(1): 105-18.

Stankovitch, Mara. 1999. Compromising on Autonomy: Mindanao in Transition. London: Conciliation Resources. https://rc-services-assets.s3.eu-west1.amazonaws.com/s3fspublic/Compromising_on_Autonomy_Mindanao_in_Transition_Accord_Issue _6.pdf.

Stanley, William, and David Holiday. 1997. 'Peace Mission Strategy and Domestic Actors: UN Mediation, Verification and Institution- building in E1 Salvador'. International Peacekeeping 4(2): 22-49.

Stedman, Stephen John. 1997. 'Spoiler Problems in Peace Processes'. International security 22(2): 5-53.

2001. Implementing Peace Agreements in Civil Wars: Lessons and Recommendations for Policymakers. New York: International Peace Academy New York.

Stedman, Stephen John, Donald S. Rothchild, and Elizabeth M. Cousens, eds. 2002. Ending Civil Wars: The Implementation of Peace Agreements. Boulder, Colo: Lynne Rienner.

Studemeister, Margarita S. 2001. 31 El Salvador: Implementation of the Peace Accords. Washington, DC: US Institute of Peace.

Svensson, Isak. 2006. 'Elusive peacemakers: a bargaining perspective on mediation in internal armed conflicts'. Department of Peace and Conflict Research, Uppsala University.

2007. 'Mediation with Muscles or Minds? Exploring Power Mediators and Pure Mediators in Civil Wars'. International negotiation 12(2): 229-48. 
2009. 'Who Brings Which Peace? Neutral versus Biased Mediation and Institutional Peace Arrangements in Civil Wars'. Journal of conflict resolution 53(3): 44669.

2011. 'Crowded with Conciliators: Exploring Multiparty Mediation in Civil Wars'. Risk and Uncertainty: Understanding and Dialogue in the 21st Century 16: 85-96.

2014. International Mediation Bias and Peacemaking: Taking Sides in Civil Wars. London: Routledge.

Svensson, Isak, and Peter Wallensteen. 2010. The Go-between: Jan Eliasson and the Styles of Mediation. Washington, D.C: United States Institute of Peace.

Talhami, Ghada Hashem. 2003. Palestinian Refugees: Pawns to Political Actors. New York: Nova Science Publishers, Inc.

Taylor, Laura K. 2015. 'Transitional Justice, Demobilisation and Peacebuilding amid Political Violence: Examining Individual Preferences in the Caribbean Coast of Colombia'. Peacebuilding 3(1): 90-108.

Teitel, Ruti G. 2000. Transitional Justice. Oxford ; New York: Oxford University Press.

The Association of Southeast Asian Nations. 1967. 'CHARTER OF THE ASSOCIATION OF SOUTHEAST ASIAN NATIONS PREAMBLE WE, THE PEOPLES of the Member States of the Association of Sout'. https://asean.org/storage/images/archive/publications/ASEAN-Charter.pdf (March 4, 2021).

The Electoral Commission. 2018. 'Results and Turnout at the EU Referendum | Electoral Commission'. https://www.electoralcommission.org.uk/who-we-are-and-whatwe-do/elections-and-referendums/past-elections-and-referendums/eureferendum/results-and-turnout-eu-referendum (March 4, 2021).

The Sentence Review Commissioners. 2008. Annual Report. Belfast. https://assets.publishing.service.gov.uk/government/uploads/system/uploads/att achment_data/file/248570/0702.pdf.

The Transitional Justice Peace Agreements Database. 2017. 'Glossary of Terms'. http://www.peaceagreements.ulster.ac.uk/glossary.html (March 4, 2021).

The UN Security Council. 1991. 'Security Council Resolution 693 (1991) [on Establishment of the UN Observer Mission in El Salvador]'. http://digitallibrary.un.org/record/113530 (March 4, 2021).

The World Bank. 2002. 'World Bank Project : Szopad Social Fund Project - P051386'. World Bank. https://projects.worldbank.org/en/projects-operations/projectdetail/P051386 (March 4, 2021). 
Theidon, Kimberly. 2007. 'Transitional Subjects: The Disarmament, Demobilization and Reintegration of Former Combatants in Colombia'. The International Journal of Transitional Justice 1(1): 66-90.

Tiempo, Casa Editorial El. 2016. 'Oficial: esta es la pregunta para el plebiscito por la paz'. El Tiempo. https://www.eltiempo.com/politica/proceso-de-paz/plebiscito-por-lapaz-pregunta-del-plebiscito-por-la-paz-en-colombia-57477 (March 3, 2021).

'Truth Commission: E1 Salvador'. United States Institute of Peace.

https://www.usip.org/publications/1992/07/truth-commission-el-salvador (March 3, 2021).

Tucker, Spencer, and Priscilla Mary Roberts, eds. 2008. The Encyclopedia of the Arab-Israeli Conflict: A Political, Social, and Military History. Santa Barbara, Calif: ABCCLIO.

Tyroler, Deborah. 1991. 'El Salvador: National Peace Consolidation Commission (Copaz) Meeting'. shorturl.at/CIS37.

UCDP. 2020. 'UCDP - Uppsala Conflict Data Program'. https://ucdp.uu.se/conflict/209 (March 4, 2021).

2021. 'UCDP - Uppsala Conflict Data Program'. https://ucdp.uu.se/country/660 (March 4, 2021).

UN. 1992. 'Report of the Secretary-General on the United Nations Observer Mission in El Salvador (S/23999), May 1992'. file:///Users/Julia/Downloads/S_23999-EN1.pdf (March 4, 2021).

1994. Ninth Report of the Director of the Human Rights Division of the United Nations Observer Mission in El Salvador (ONUSAL). http://digitallibrary.un.org/record/182925/files/A_49_59\%26S_1994_47EN.pdf (March 4, 2021).

1995a. The Situation in Central America: Procedures for the Establishment of Firm and Lasting Peace and Progress in Fashioning a Region of Peace, Freedom, Democracy and Development. https://digitallibrary.un.org/record/199973/files/A_50_517-EN.pdf (March 4, 2021).

1995b. Thirteenth Report of the Director of the Human Rights Division of the United Nations Observer Mission in El Salvador (ONUSAL), 1 October 1994 to 31 March 1995.

https://digitallibrary.un.org/record/178020/files/A_49_888_S_1995_281EN.pdf (March 4, 2021).

1997a. Assessment of the Peace Process in El Salvador Report of the SecretaryGeneral (A/51/917), 1 July 1997. 
https://digitallibrary.un.org/record/240061/files/A_51_917-EN.pdf (March 4, 2021).

1997b. The Situation in Central America: Procedures for the Establishment of Firm and Lasting Peace and Progress in Fashioning a Region of Peace, Freedom, Democracy and Development.

https://digitallibrary.un.org/record/248067/files/A_52_731-EN.pdf (March 4, 2021).

1998. The Situation in Central America: Procedures for the Establishment of a Firm and Lasting Peace and Progress in Fashioning a Region of Peace, Freedom, Democracy and Development.

https://digitallibrary.un.org/record/258355/files/A_52_1008-EN.pdf (October 30, 2017).

2006. Report of the Commission of Inquiry on Lebanon Pursuant to Human Rights Council Resolution $S-2 / 1^{*}$.

https://web.archive.org/web/20070115172923/http://www.ohchr.org/english/bo dies/hrcouncil/docs/specialsession/A.HRC.3.2.pdf (November 13, 2017).

. 2014. 'Ta'if Accords.' https://peacemaker.un.org/lebanon-Ta'if accords89 (November 13, 2017).

2017. 'Chapter VII'. https://www.un.org/en/sections/un-charter/chapter-vii/ (March 4, 2021).

UN Peacemaker. 1989. 'Taif Accords | UN Peacemaker'. https://peacemaker.un.org/lebanontaifaccords89 (March 4, 2021).

UNDP. 2003. 'The GoP_UN/Multi-Donor Programme Phase 3'. http://erc.undp.org/evaluation/documents/download/3144 (March 4, 2021).

2018. 'ACT for Peace Project'.

https://info.undp.org/docs/pdc/Documents/PHL/46336\%20ACT\%20for\%20Pe ace\%20ProDoc.pdf (March 4, 2021).

United States. Congress. Commission on Security and Cooperation in Europe. 2005.

Developments In Northern Ireland, Part I: Human Rights and Police Reform..., [CSCE 108-2-2], [CSCE 108-2-3], March 16, 2004, May 5, 2004, 108-2

United States. Dept. of State, United States. Congress. House. Committee on Foreign Affairs, United States. Congress. Senate. Committee on Foreign Relations, and United States. Congress. House. Committee on International Relations. 1989. Country Reports on Human Rights Practices : Report (Lebanon) Submitted to the Committee on Foreign Affairs, U.S. House of Representatives and Committee on Foreign Relations, U.S. Senate by the Department of State in Accordance with Sections 116(d) and 502B(b) of the Foreign Assistance Act of 1961, as Amended. Washington, D.C. : U.S. G.P.O. : For sale by the Supt. of Docs., U.S. G.P.O. http://archive.org/details/countryreportson1989unit (March 4, 2021). 
1992. Country Reports on Human Rights Practices : Report (Lebanon) Submitted to the Committee on Foreign Affairs, U.S. House of Representatives and Committee on Foreign Relations, U.S. Senate by the Department of State in Accordance with Sections 116(d) and 502B(b) of the Foreign Assistance Act of 1961, as Amended. Washington, D.C. : U.S. G.P.O. : For sale by the Supt. of Docs., U.S. G.P.O. http://archive.org/details/countryreportson1992unit (March 4, 2021).

Unruh, Jon, and Rhodri Williams. 2013. Land and Post-Conflict Peacebuilding. New York: Routledge.

Urbain, Olivier. 2017. Risk and Uncertainty: Understanding and Dialogue in the 21st Century.

http://www.vlebooks.com/vleweb/product/openreader?id=noneandisbn=97813 51492881 (March 3, 2021).

U.S. Department of State. 1998. '1997 Human Rights Report: The Philippines'. https://19972001.state.gov/global/human_rights/1997_hrp_report/philippi.html (March 4, 2021).

—. 2002. '2001 County Reports on Human Rights Practices'. https://20092017.state.gov/j/drl/rls/hrrpt/2001//index.htm (March 4, 2021).

Vinjamuri, Leslie, and Jack Snyder. 2004. 'Advocacy and Scholarship in the Study of International War Crime Tribunals and Transitional Justice'. Annu. Rev. Polit. Sci. 7: 345-62.

Von Hehn, Arist. 2011. The Internal Implementation of Peace Agreements after Violent Intrastate Conflict Guidance for Internal Actors Responsible for Implementation. Leiden: Martinus Nijhoff Publishers.

Vuković, Siniša. 2017. International Multiparty Mediation and Conflict Management: Challenges of Cooperation and Coordination. London; New York: Routledge

Wallensteen, Peter. 2011. Peace Research: Theory and Practice. Milton Park, Abingdon, Oxon [England]; New York: Routledge.

2015. Quality Peace: Peacebuilding, Victory, and World Order. New York, NY: Oxford University Press.

Wallensteen, Peter, and Isak Svensson. 2014. 'Talking Peace: International Mediation in Armed Conflicts'. Journal of Peace Research 51(2): 315-27.

Wallensteen, Peter. 2012. Understanding Conflict Resolution. 3rd ed. London; Thousand Oaks, Calif: SAGE Publications.

Walsh, Dawn. 2017. Independent Commissions and Contentious Issues in Post-Good Friday Agreement Northern Ireland. 1st ed. 2017. Cham: Springer International Publishing : Imprint: Palgrave Macmillan. 
Walter, Barbara F. 1997. 'The Critical Barrier to Civil War Settlement'. International organization 51(3): 335-64.

Walter, Barbara F. 2002. Committing to Peace: The Successful Settlement of Civil Wars. Princeton, N.J: Princeton University Press.

Walter, Barbara F. 2011. 'Conflict Relapse and the Sustainability of Post-Conflict Peace'.

Ward, Paul. 2010. Family Law in Ireland. Alphen aan den Rijn, The Netherlands: Kluwer Law International.

'What We Do NI Human Rights Commission (NIHRC)'. 2020. https://www.nihrc.org/index.php?/about-us/what-we-do (March 4, 2021).

Wilford, Rick. 2000. 'Designing the Northern Ireland Assembly'. Parliamentary affairs 53(3): 577-90.

Wilkinson, Tracy. 1992. 'Salvadoran Rebels Halt Demobilization'. Los Angeles Times. https://www.latimes.com/archives/la-xpm-1992-11-25-mn-1049-story.html (March 4, 2021).

Williamson, Arthur, Duncan Scott, and Peter Halfpenny. 2000. 'Rebuilding Civil Society in Northern Ireland: The Community and Voluntary Sector's Contribution to the European Union's Peace and Reconciliation District Partnership Programme'. Policy and Politics 28(1): 49-66.

Wimmen, Heiko. 2016. 'Libanon - Geschichte und Politik | bpb'. bpb.de. https://www.bpb.de/gesellschaft/migration/laenderprofile/228362/libanongeschichte-und-politik (March 4, 2021).

Wolff, Stefan, and Oya Dursun-Özkanca. 2016. External Interventions in Civil Wars: The Role and Impact of Regional and International Organisations. London and New York.

Wood, Elisabeth Jean. 2003. Insurgent Collective Action and Civil War in El Salvador. New York: Cambridge University Press.

Worthington, Everett L, Steven J Sandage, and Jack W Berry. 2000. 'Group Interventions to Promote Forgiveness'. Forgiveness: Theory, research, and practice: 228-53.

Zahar, Marie-Joëlle. 2005. Power Sharing in Lebanon: Foreign Protectors, Domestic Peace, Zahar, M.-J. (2005b). Power sharing in Lebanon: Foreign protectors, domestic peace, and democratic failure. In P. G. Roeder and D. Rothschild (Eds.), Sustainable Peace : Power and Democracy After Civil Wars (pp. 219240). Ithaca and London: Cornell University Press.

Zartman, I. William, ed. 2007. Peacemaking in International Conflict: Methods and Techniques. Rev. ed. Washington, D.C: United States Institute of Peace. 
Zartman, I William, and Saadia Touval. 1985. 'International Mediation: Conflict Resolution and Power Politics'. Journal of Social Issues 41(2): 27-45.

Zartman, William I, and Saadia Touval. 1996. 'International Mediation in the Post-Cold War Era” Crocker, Chester A, Fen Osler Hampson, Pamela Aall (Eds.). Managing Global Chaos: Sources of and Responses to International Conflict'.

Washington, D.C.: United States Institute of Peace Press. 


\section{Appendix}

Appendix A: implementation scores of selected cases over a period of ten years.

El Salvador Lebanon United Kingdom The Philippines

Years:

\begin{tabular}{ccccc}
\hline $\mathbf{1 .}$ & $\mathbf{5 6 , 9 4 4 4 4}$ & 24,07407 & 58,33333 & 16,66667 \\
\hline $\mathbf{2 .}$ & 68,05556 & 31,48148 & 72,61905 & 23,61111 \\
\hline $\mathbf{3 .}$ & 76,38889 & 40,74074 & 80,95238 & 23,61111 \\
\hline $\mathbf{4 .}$ & 77,77778 & 46,2963 & 83,33334 & 26,38889 \\
\hline $\mathbf{5 .}$ & 88,88889 & 55,55556 & 84,52381 & 26,38889 \\
\hline $\mathbf{6 .}$ & 93,05556 & 55,55556 & 80,95238 & 50 \\
\hline $\mathbf{7 .}$ & 93,05556 & 55,55556 & 84,52381 & 50 \\
\hline $\mathbf{8 .}$ & 95,83334 & 55,55556 & 86,90476 & 51,38889 \\
\hline $\mathbf{9 .}$ & 95,83334 & 59,25926 & 88,09524 & 56,94444 \\
\hline $\mathbf{1 0 .}$ & $\mathbf{9 5 , 8 3 3 3 4}$ & $\mathbf{5 9 , 2 5 9 2 6}$ & $\mathbf{9 5 , 2 3 8 1}$ & $\mathbf{5 9 , 7 2 2 2 2}$ \\
\hline
\end{tabular}

Source: Data based on the "Peace Accord Matrix" (Joshi et al. 2015).

Appendix B: first assembly election result in Northern Ireland

\section{No. $1^{\text {st }}$ \\ Preference Votes}

Party name

Social Democratic and Labour Party (SDLP)

Ulster Unionist Party (UUP)

Democratic Unionist Party (DUP)

Sinn Féin (SF)

Alliance Party of Northern Ireland (APNI)

United Kingdom Unionists (UKU)

Progressive Unionist Party (PUP)

NI Women's Coalition (WC)
Seats

$\begin{array}{lll}177,963 & 21.96 & 24 \\ 172,225 & 21.25 & 28 \\ 145,917 & 18.01 & 20 \\ 142,858 & 17.63 & 18 \\ 52,636 & 6.50 & 6 \\ 36,541 & 4.51 & 5 \\ 20,634 & 2.55 & 2 \\ 13,019 & 1.61 & 2\end{array}$

Source: Assembly Election (NI) Thursday 25 June 1998 


\section{Assurance}

1. Die Gelegenheit zum vorliegenden Promotionsvorhaben ist mir nicht kommerziell vermittelt worden. Insbesondere habe ich keine Organisationen eingeschaltet, die gegen Entgelt Betreuerinnen und Betreuer für die Anfertigung von Dissertationen sucht oder die mir obliegenden Pflichten hinsichtlich der Prüfungsleistungen für mich ganz oder teilweise erledigt.

2. Ich versichere, dass ich die eingereichte Dissertation „Power Mediators and Pure Mediators: Exploring their Impact on Implementing Internal Peace Agreements". selbstständig und ohne unerlaubte Hilfsmittel verfasst habe; fremde Hilfe habe ich dazu weder unentgeltlich noch entgeltlich entgegengenommen und werde dies auch in Zukunft so halten. Anderer als der von mir angegebenen Hilfsmittel und Schriften habe ich mich nicht bedient. Alle wörtlich oder sinngemäß den Schriften anderer Autoren entnommenen Stellen habe ich kenntlich gemacht.

3. Die eingereichte Dissertation habe ich nicht bereits in einem anderen Prüfungsverfahren vorgelegt.

4. Des Weiteren ist mir bekannt, dass Unwahrhaftigkeiten hinsichtlich der vorstehenden Erklärung die Zulassung zur Promotion ausschließen bzw. später zum Verfahrensabbruch oder zur Rücknahme des erlangten Titels berechtigen.

Dogukan Cansin Karakus 